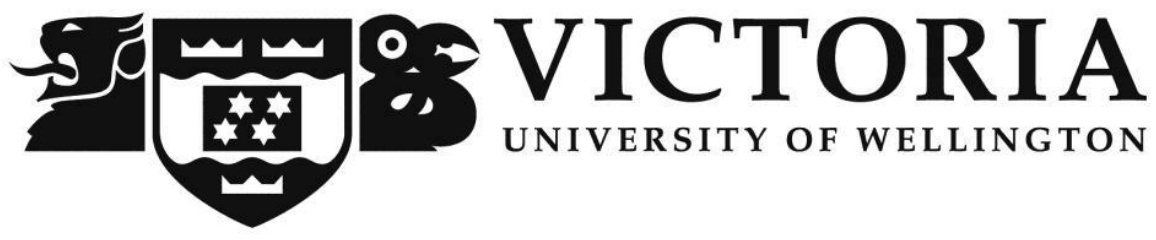

School of Geography, Environment, and Earth Science

Victoria University of Wellington

New Zealand

\title{
The relevance of vocational education to the livelihoods of rural youth, Luang Prabang Province, Laos
}

Phonexay Soukkaseum

Thesis submitted to Victoria University of Wellington in partial fulfilment of the requirements for the degree of Master of Development Studies 



\section{Abstract}

Poverty reduction is a top global development priority. Among Least Developed Countries (a United Nations measurement which includes Laos), poverty reduction has been set as the highest development priority for governments, especially since the early 2000s. Scholars and researchers argue that raising national human capital through the provision of equitable access and quality of education could not only reduce poverty, but also increase economic growth, promote democracy, and ensure the sustainability of development.

This research examines specifically the role of technical and vocational education and training (TVET) in supporting the livelihoods of rural people, especially the Indigenous youth in Luang Prabang province, situated in northern Laos. A sustainable livelihood approach, with an emphasis on human capital and human capabilities, was employed to examine this relationship. Qualitative and ethnographic research methodologies were employed, with interviews, a focus group and transect walks used as methods for data collection and analysis.

Results show that the current TVET policy and interventions have concentrated primarily on achieving (income) poverty reduction and economic development objectives, neglecting the importance of other multiple dimensions of human development. This research also reveals that the livelihood aspirations of rural youth are diverse and extend beyond economic prospects. They aspire for general wellbeing, democracy (self-agency and freedom) and social justice. If these dimensions of human development are to be promoted, the government may need to reshape its policy direction by incorporating a human capabilities approach in TVET, or more broadly in the national education system, while still fulfilling the desire for economic development objectives.

Keywords: education, TVET, livelihoods, rural youth, development, Laos 
This page intentionally left blank 
This thesis is dedicated to my mother, Pan, and my father, Sichanh, for their love, endless support and encouragement. 
This page intentionally left blank 


\section{Acknowledgements}

This Masters Thesis is the fruit of great contributions from many people. I wish to acknowledge them in the chronological order of my journey.

Phouthone Phamixay, I thank you for your consultation, support, advice, and contribution during my fieldwork in Luang Prabang. Porxiong Yiayeexiong and Somsack Yang: your knowledge sharing about Hmong's culture, traditions and beliefs enabled me to unpack the messages participants conveyed in this research.

Soulaxay Bounthideth, thank you for constantly finding information needed. Sinhthavong Siyavong and Vilaisone Keophuthone, thank you for providing an office space while I was there in Vientiane. That helped me work on my thesis effectively.

To the participants in communities, the youth and educators in the colleges, development workers and government officials in Vientiane. Without your contribution, this research would not be accomplished. The debt I owe you cannot be paid by myself, but by the degree to which this thesis contributes to our country for the mutual benefits of all.

To my classmates, Hang Trinh and Theresa Sila Wikaningtyas, without your language support, ideas and sometimes criticism, this research would not come to fruition. Your saying, "He is the man of aspiration," indicates the length of time you listened, and the understanding of what I was doing in this research. Hawa Kusuma Setyawati Fitzgerald, your chocolate and mental support meant so much to keep me working. Ratanakvisal Chean, thank you for your encouragement and sharing which helped move me along each day. Alex Hill, thank you for your help in constructing my thoughts and ideas. Your time and effort spent to support me is highly appreciated.

Dr Bernadette V. Gonzales, your comments encouraged me to keep working hard on my research. Mouthita Phonephetrath, I appreciate your contribution, encouragement, and advice. Tai Anh Vu, Ph.D candidate: your comments and suggestions contributed significantly to this research.

Special thanks go to Victoria International. My academic achievement is a result of your excellent support and service. To Student Learning Support for 
helping me learn how to polish my language, making it clearer and succinct. Your support was not only during my thesis writing, but from the beginning of my time entering academic study in New Zealand. I also wish to thank the Disability Service for your great support during my study.

Dr Marcela Palomino-Schalscha, my supervisor, saying thank you does not seem enough for what you have done for me. Your comments, feedback, and advice provided invaluable input to this research. You helped me to move through the confusion to successfully writing the full thesis. I am grateful for your patience throughout the journey. Your constant encouragement and support from the beginning to the end motivated me to accomplish this research. Professor John Overton, my interim supervisor, thank you for being there for me while Marcela was away, and thank you for your powerful advice.

Finally, to my sisters and brothers, thank you for bearing all the family burden while I was away. I admire your dedication to cherishing to our parents, physically, psychologically and financially. 


\section{Acronyms}

\begin{tabular}{|c|c|}
\hline ADB & Asian Development Bank \\
\hline AEC & $\begin{array}{l}\text { Association of Southeast Asian Nations (ASEAN) } \\
\text { Economic Community }\end{array}$ \\
\hline CBT & Competency-Based Training \\
\hline $\mathrm{CCU}$ & Career Counselling Unit \\
\hline CIA & Cumulative Impact Assessment \\
\hline DCT & Dual Cooperative Training system \\
\hline EFA & Education for All \\
\hline ESD & Education for Sustainable Development \\
\hline ESDF & Education Sector Development Framework \\
\hline FDI & Foreign Direct Investment \\
\hline GIZ & Deutsche Gesellschaft für Internationale Zusammenarbeit \\
\hline GPI & Gender Parity Index \\
\hline IAF & Inclusive Access Fund \\
\hline IVET & Integrated Vocational Education and Training \\
\hline Lao PDR (Laos) & Lao People's Democratic Republic \\
\hline LDA & Luxembourg Development Agency \\
\hline LFAP & Land and Forest Allocation Programme \\
\hline LPB-TVET & $\begin{array}{l}\text { Luang Prabang Technical and Vocational Education and } \\
\text { Training }\end{array}$ \\
\hline MAF & Ministry of Agriculture and Forestry \\
\hline MAF-TVET & TVET institutions under MAF \\
\hline MDGs & Millennium Development Goals \\
\hline MOES & Ministry of Education and Sports ${ }^{1}$ \\
\hline MOES-TVET & TVET institutions under MOES \\
\hline MPI & Ministry of Planning and Investment \\
\hline NA & National Assembly of Lao PDR \\
\hline NAFC & Northern Agriculture and Forestry College \\
\hline
\end{tabular}

\footnotetext{
${ }^{1}$ The term MOES is formerly known as MOE (Ministry of Education). According to Noonan and Noonan (2017, pp. 42, 45), MOES was re-organized and re-named MOE in April, 1993. It was merged with the Lao National Sports Committee (LNSC) in September, 2011 and renamed MOES again.
} 


\begin{tabular}{|c|c|}
\hline NEM & New Economic Mechanism \\
\hline NGOs & Non-Governmental Organisations \\
\hline NGPES & National Growth and Poverty Eradication Strategy \\
\hline NTFPs & Non-Timber Forest Products \\
\hline NVQF & National Vocational Qualifications Framework \\
\hline ODA & Official Development Assistance \\
\hline PPA & Participatory Poverty Assessment \\
\hline PPPs & Public-Private Partnerships \\
\hline PRSPs & Poverty Reduction Strategy Papers \\
\hline RTM & Round Table Meeting \\
\hline SDC & Swiss Agency for Development Cooperation \\
\hline SDGs & Sustainable Development Goals \\
\hline (S)SEZs & (Specific) Special Economic Zones \\
\hline SLA & Sustainable Livelihood Approach \\
\hline SMC & Social Marketing Campaign \\
\hline SMEs & Small-Medium Enterprises \\
\hline STVET & $\begin{array}{l}\text { Strengthening Technical and Vocational Education and } \\
\text { Training project }\end{array}$ \\
\hline SURAFCO & $\begin{array}{l}\text { A project supports to the reform of the Luang Prabang } \\
\text { Agriculture and Forestry College }\end{array}$ \\
\hline SWGs & Sector Working Groups \\
\hline TVED-MOES & $\begin{array}{l}\text { Technical and Vocational Education and Training } \\
\text { Development, MOES }\end{array}$ \\
\hline TVET & Technical and Vocational Education and Training \\
\hline UNDP & United Nations Development Programme \\
\hline UNESCO & $\begin{array}{l}\text { United Nations Educational, Scientific and Cultural } \\
\text { Organization }\end{array}$ \\
\hline UNESCO-UNEVOC & $\begin{array}{l}\text { International Centre for Technical and Vocational } \\
\text { Education and Training of the UNESCO }\end{array}$ \\
\hline VELA Programme & Vocational Education in Laos \\
\hline VUW-HEC & $\begin{array}{l}\text { Human Ethics Committees of the Victoria University of } \\
\text { Wellington }\end{array}$ \\
\hline
\end{tabular}




\section{Terms and definitions}

Indigenous Peoples

Youth

Ban

Fa laang

Hay/hai

Kmhmu

Kum-ban

Na/naa

sa-vang-sa-vai

Souan/suan
Indigenous communities, peoples and nations are those which, having a historical continuity with pre-invasion and pre-colonial societies that developed on their territories, consider themselves distinct from other sectors of the society now prevailing in those territories, or parts of them. They form at present non-dominant sectors of society and are determined to preserve, develop and transmit to future generations their ancestral territories, and their ethnic identity, as the basis of their continued existence as peoples, in accordance with their own cultural patterns, social institutions and legal systems (Martínez Cobo, cited in Eversole, McNeish, \& Cimadamore, 2005, p. 5).

In this research, the term indigenous peoples refers to ethnic minorities living in remote and geographically isolated areas of Laos (World Bank, 2005a)

Young people aged 18-24

Village

Western foreigners

Sifting cultivation/mountainous food production for selfsufficiency

An ethnic group belonging to the Mon-Khmer sub-branch of the Austro-Asiatic language family. Alternative spellings are Khти, Катти, Khmоu, Khamou, and Khıти (Higashi, 2015, p. 255)

Village cluster

Paddy farming/wetland cultivation/permanent cultivation

Water flows, light shines (a metaphor to express the modern living conditions of living in the city)

Mixed cultivation: cash crops or kitchen garden 
This page intentionally left blank 


\section{Table of Contents}

Acknowledgements

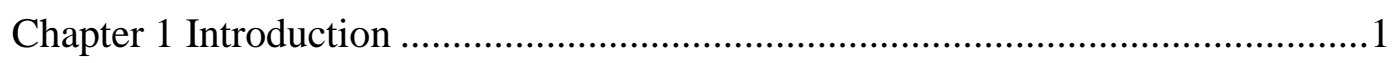

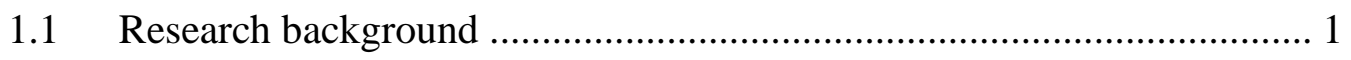

1.2 Research objectives and questions ...................................................... 5

1.3 Research approach and methodology ................................................ 6

1.4 Research significance linking to development theory and practice ......... 6

1.5 Thesis outline ............................................................................... 7

Chapter 2 Education, development and sustainable livelihoods ............................ 9

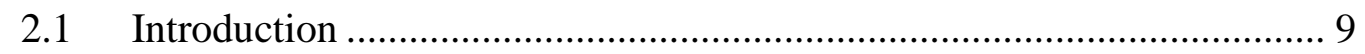

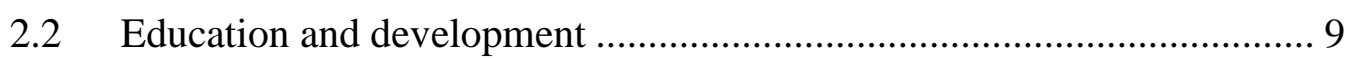

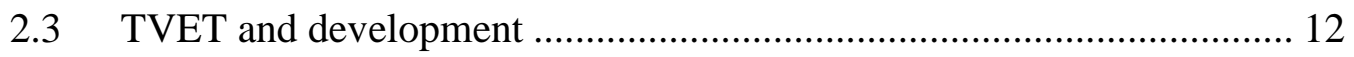

2.4 Sustainable livelihood approach....................................................... 14

2.4.1 The definition and components of sustainable livelihoods ............ 14

2.4.2 Sustainable livelihoods as an analytical framework ..................... 16

2.4.3 Individuals and household as units of analysis ............................ 17

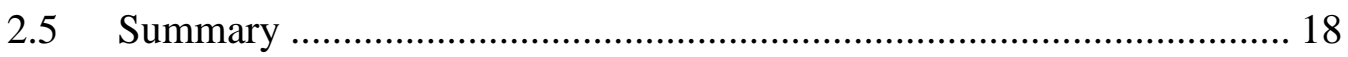

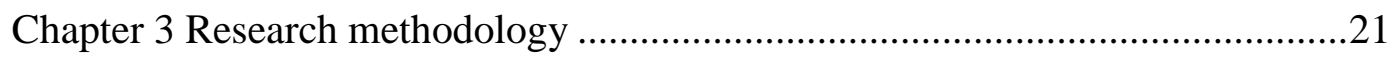

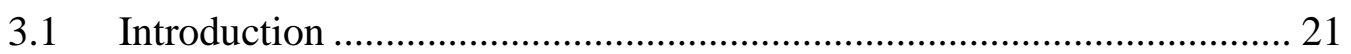

3.2 Social constructivist epistemology ................................................ 21

3.3 Qualitative and ethnography methodologies ..................................... 23 
3.4 Recruitment of participants, locations, and research timeline 23

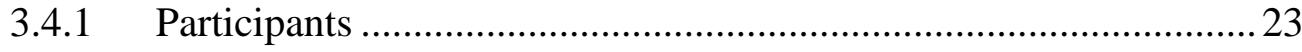

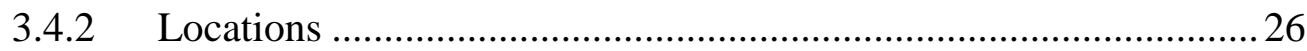

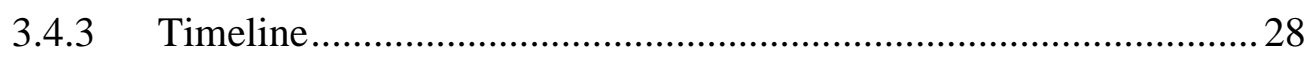

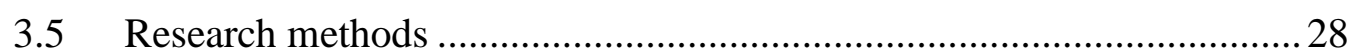

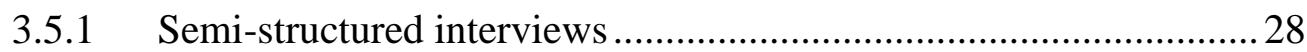

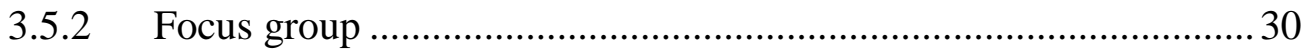

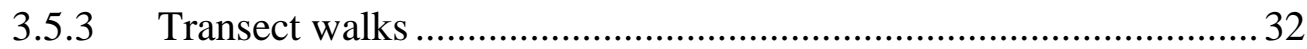

3.6 Data preparation, analysis, and interpretation....................................... 35

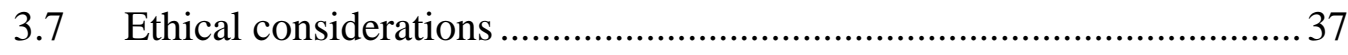

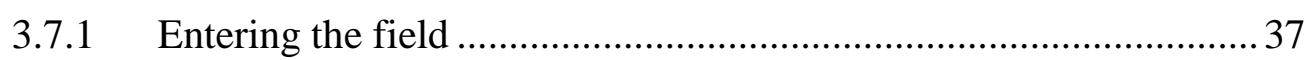

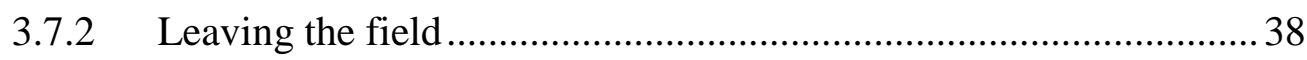

3.7.3 Interpreting the meanings and use of language ............................. 39

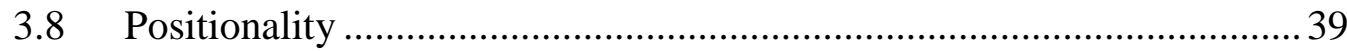

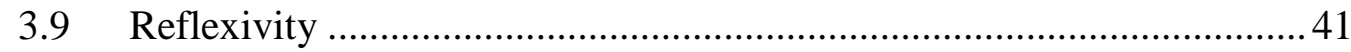

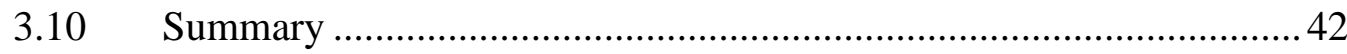

Chapter 4 The social, economic and political contexts of Laos .......................... 43

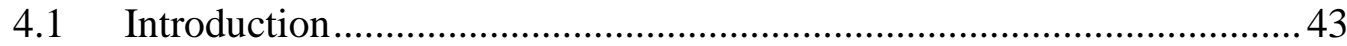

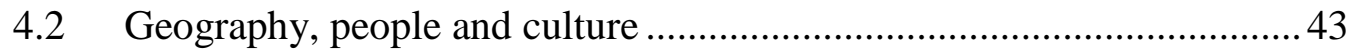

4.3 Political system and socio-economic development .............................5 50

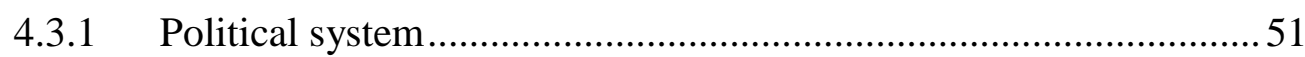

4.3.2 Economic reform and key elements reflecting rural livelihoods.... 52

4.3.3 Development priorities and performance indicators ......................53

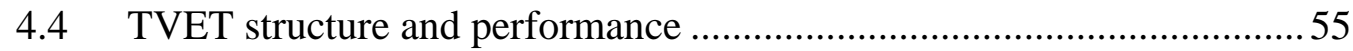

4.4.1 TVET system and administration .................................................55

4.4.2 National Vocational Qualifications Framework (NVQF) ...............56

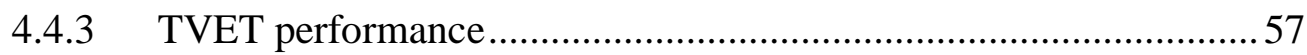

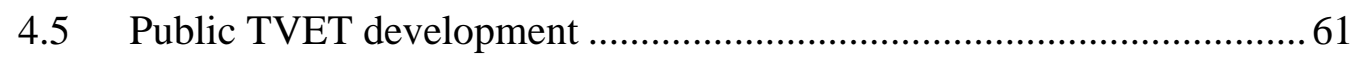

4.5.1 Government development plans, strategies and funding .................61

4.5.2 Donors' development projects, strategies and funding ...................63 63

4.6 TVET colleges in Luang Prabang province - case studies.....................69

4.6.1 Northern Agriculture and Forestry College..................................... 69

4.6.2 Luang Prabang TVET College .................................................. 71

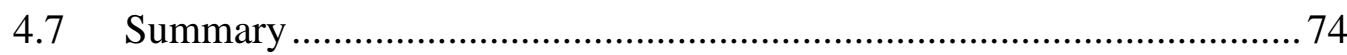


Chapter 5 Livelihood activities and challenges in rural villages .75

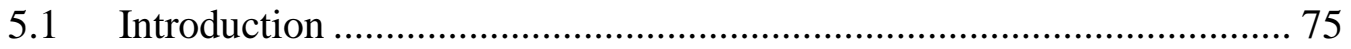

5.2 Clarification of term use - village and household classification............ 76

5.3 Village history and characteristics..................................................... 76

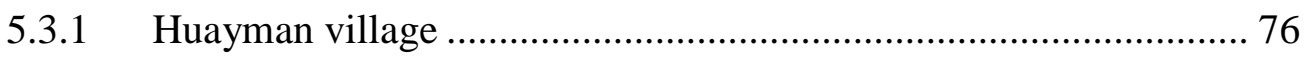

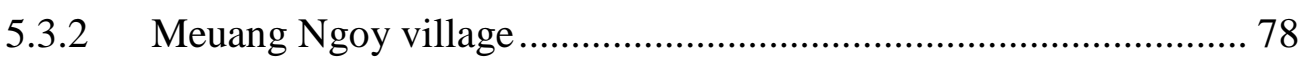

5.4 Current livelihood activity and coping strategy .................................. 80

5.4.1 Farm-based livelihoods .......................................................... 80

5.4.2 Non-farm based livelihoods ......................................................... 86

5.4.3 Education and migration as new livelihood strategies .................. 92

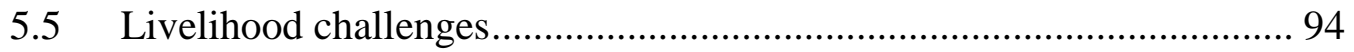

5.5.1 Decline in natural capital .......................................................... 94

5.5.2 Tourism impact due to hydropower development projects............ 96

5.5.3 Limited access to markets ........................................................... 99

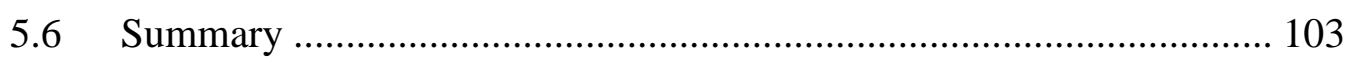

Chapter 6 Rural youth and TVET: Aspirations, influences and limitations ........105

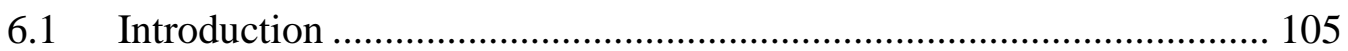

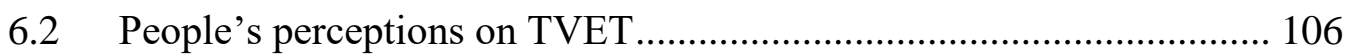

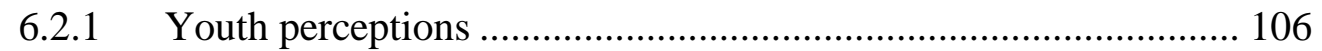

6.2.2 Community perceptions …........................................................ 108

6.2.3 Employer perceptions............................................................... 108

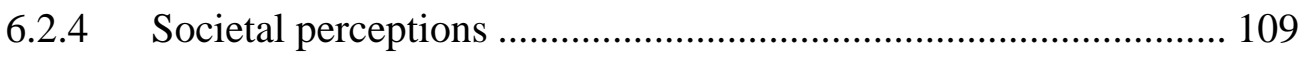

6.3 Youth decision-making and influencing factors .............................. 111

6.3.1 Decision-making ................................................................. 111

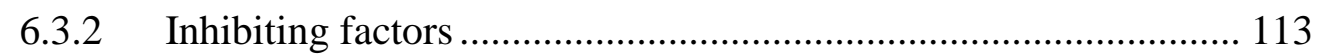

6.4 Youth livelihood aspirations ………............................................ 117

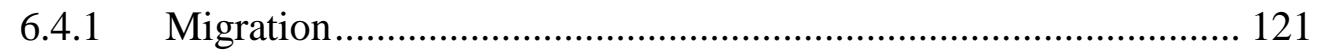

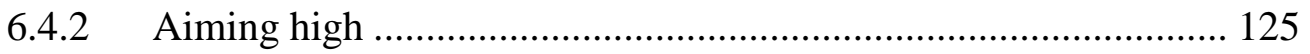

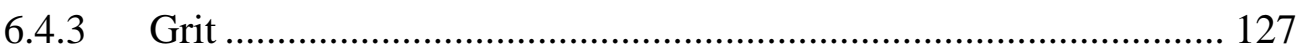

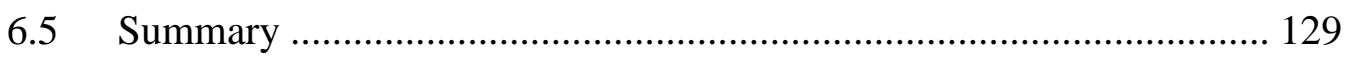

Chapter 7 TVET and development in Laos: Priorities, challenges and areas for further attention.

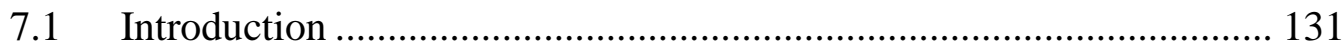

7.2 Priorities and challenges for TVET development in Laos ................. 132 
7.2.1 Reducing poverty and increasing economic growth.................... 132

7.2.2 Addressing skills mismatch ....................................................... 136

7.2.3 Raising attractiveness and recognition of TVET ......................... 138

7.3 Socio-political contexts reflecting TVET development challenges...... 141

7.3.1 Policy development and planning ............................................. 141

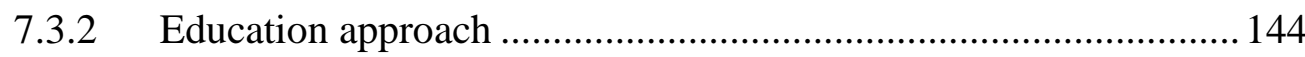

7.4 Applying the capability approach in education: A policy option? ....... 145

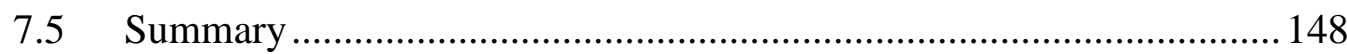

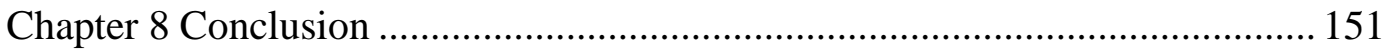

8.1 Linkages between TVET, rural livelihoods and development.............. 152

8.2 Areas for further expansion of TVET ............................................. 155

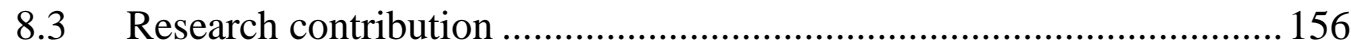

8.4 Research limitation and areas for further exploration.......................... 156

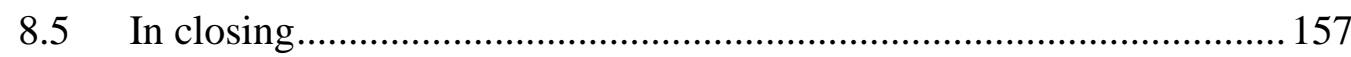

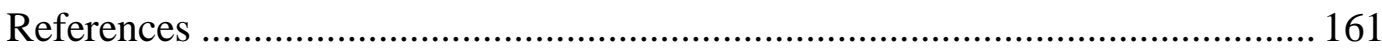

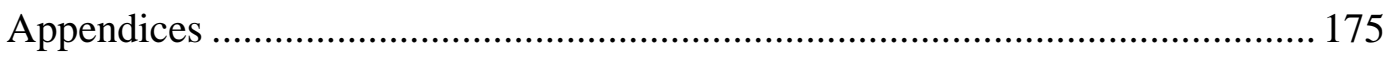




\section{List of Boxes}

Box 5.1 Rural tourism and livelihoods: A school leaver as a local tour guide 91

Box 6.1 Migration - A livelihood strategy for life betterment 122

Box 6.2 Home, sweet home - "I don't want to live in the city" 124

Box 6.3 Aiming high - "I strive to escape the poverty of our family" .......................... 126

Box 6.4 Perseverance - "Where there is a will, there is a way". 


\section{List of Figures}

Fig. 2.1 A sustainable rural livelihood analysis framework .......................................... 17

Fig. 3.1 Participants (youth) by gender and ethnic group ..............................................2 25

Fig. 3.2 Research locations in Luang Prabang province ……..........................................2 27

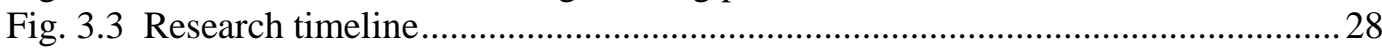

Fig. 3.4 Focus group activity: A 'MetaCards' approach .................................................... 31

Fig. 3.5 Community asset map of Ban Huayman.............................................................. 33

Fig. 3.6 Community asset map of Ban Meuang Ngoy ...................................................... 34

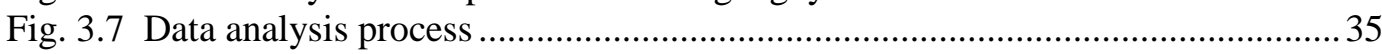

Fig. 4.1 Laos: The land-locked country and identified mountainous areas.......................4 44

Fig. 4.2 Lao population (2015), by region and province............................................ 45

Fig. 4.3 Demographical characteristics by ethno-linguistic categories (A, B, C and D) . 48

Fig. 4.4 The overall students' enrolment trends in TVET in Laos..................................58

Fig. 4.5 Gender parity index (GPI) in the education sector in Laos.................................59

Fig. 4.6 Percentage of shared costs for agricultural TVET development ........................63

Fig. 4.7 Flow of funding for TVET development in Lao PDR .............................................. 68

Fig. 4.8 The enrolment trends of NAFC's students by gender........................................ 70

Fig. 4.9 The enrolment trends of NAFC's students by ethnic group ................................ 71

Fig. 4.10 The enrolment trends of LPB-TVET by gender ............................................. 72

Fig. 4.11 Number of students enrolled in the industrial sector by gender........................73

Fig. 4.12 Number of students enrolled in the service sector by gender .......................... 73

Fig. 5.1 Number and percentage of households, by ethnic groups................................... 77

Fig. 52 Number and percentage of households, by socio-economic status ..................... 78

Fig. 5.3 Number and percentage of households, by socio-economic status ....................79

Fig. 5.4 Rice field with supplementary crops (corn, sugar cane) in Ban Huayman ..........83 83

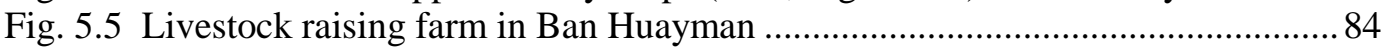

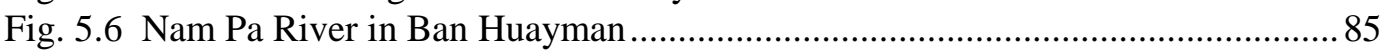

Fig. 5.7 Examples of rural tourism services in Ban Meuang Ngoy ................................. 89

Fig. 5.8 Nam Ou 3 hydropower project in Laos (2012) .............................................. 98

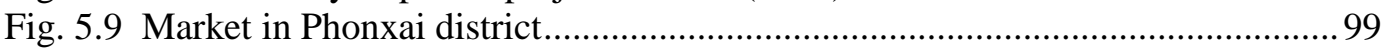

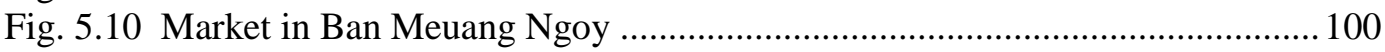

Fig. 5.11 Morning market in Meuang Ngoy district .................................................... 101 


\section{List of Tables}

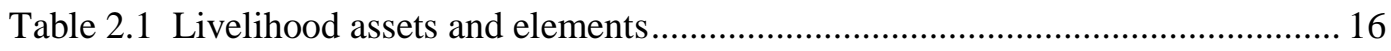

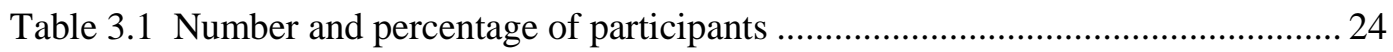

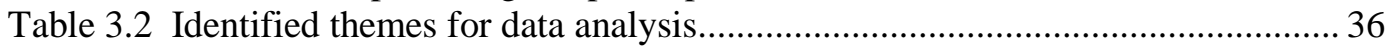

Table 4.1 The ethno-linguistic families and categories ................................................. 46

Table 4.2 Incidence of poverty by geography and ethnic groups, 2002-2003 ................ 50

Table 4.3 National Vocational Qualification Framework (NVQF) in Lao PDR .............. 56

Table 4.4 MOES-TVET institutions, enrolments and Gender Parity Index (GPI) .......... 59

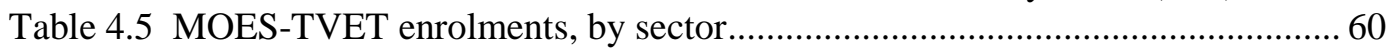

Table 4.6 Number of enrolments in MAF-TVET institutions, by region .......................... 61

Table 4.7 TVET development objectives and strategies in Lao PDR ...............................66

Table 4.8 External and internal funding for TVET development in Laos ........................ 67

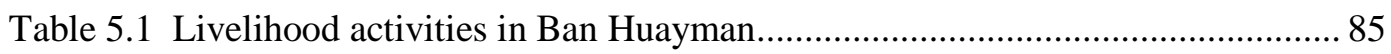

Table 5.2 Livelihood activities in Ban Meuang Ngoy ................................................... 92

Table 5.3 Current land use in Bo Kum-ban (village cluster) in 2010 .............................. 95

Table 5.4 Projected agricultural land use in Bo Kum-ban (village cluster) by $2020 \ldots \ldots . .96$

Table 5.5 Summary of livelihood activities in two visited villages .............................. 102

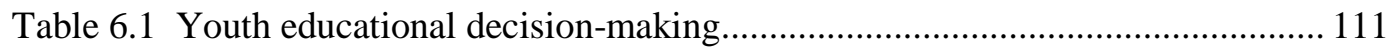

Table 6.2 Aspirations of youth from Luang Prabang TVET …..................................... 117

Table 6.3 Aspirations of youth from Souphanouvong University ................................ 118

Table 6.4 Aspirations of youth from Northern Agriculture and Forestry College......... 119

Table 6.5 Aspirations of youth, expressed in a group................................................... 120

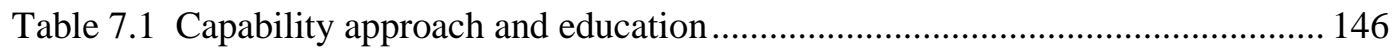


This page intentionally left blank 


\section{Chapter 1 Introduction}

\subsection{Research background}

Since the early 2000s, governments and development institutions around the world have come together to fight global poverty. The Millennium Development Goals (MDGs) was the first global agenda established to eradicate poverty and hunger by 2015 (Maxwell, 2003). Since then, several documents, undersigned by a large representation of states and international organisations, have been produced. Among others, a key policy document is the Poverty Reduction Strategy Papers (PRSPs). The principal objective of the PRSPs is to define national strategies to promote broad-based economic growth and reduce poverty (Tarabini \& Jacovkis, 2012). In other words, PRSPs are regarded as "a professedly comprehensive, country-driven approach to poverty reduction” (Craig \& Porter, 2003, p. 53).

Despite several attempts of national and international institutions, poverty reduction remains the greatest global challenge (United Nations, 2012). Indigenous peoples, approximately 370 million worldwide, are "the poorest of the poor" (ILO, 2016a, p. 1). "Their traditional ways of life, livelihoods and practices are increasingly under threat owing to a range of factors" (ILO, 2016a, p. 1); "their material standard of living is lower; their risk of disease and early death is higher; ... their educational opportunities are more limited; [and] their political participation and voice more constrained" (Eversole et al., 2005, p. 2).

In South and Southeast Asia, indigenous peoples "have been or are being impoverished by a number of forces which are beyond their control and often irreversible...; [these include] dispossession of their traditional lands, the denial of access to forests and other natural resources, or the prohibition of some livelihood practices, such as shifting cultivation" (Erni, 2015, p. 3). Freeing humanity from poverty is, therefore, a matter of urgency, and is a number-one development priority 
among governments and development institutions in least-developed countries (United Nations, 2012, 2015b).

Poverty eradication is not an easy task as both poverty and its eradication involve multiple human factors (Alkire, 2002). As it is defined, "poverty is, in many ways, the worst of human deprivation. It can involve not only the lack of necessities of material well-being, but also the denial of opportunities of living a tolerable life" (Anand \& Sen, 1997, p. 4). Thus, it cannot be measured simply by the volume of the individual's income, but must include several aspects of an individual's life (Anand \& Sen, 1997). Hence, poverty cannot be eradicated by just a single instrument.

It has been argued that education is viewed as a critical means to ensure poverty reduction (Cremin \& Nakabugo, 2012; Rolleston, 2011; Tilak, 2002). Education has been encapsulated as a key element for achieving the goals of MDGs and PRSPs (Maxwell, 2003; Tarabini \& Jacovkis, 2012). It is believed that education "not only generates economic benefits such as increasing salaries, productivity and growth, but also produces social benefits related to social cohesion, political participation, and even to fertility and health" (Tarabini \& Jacovkis, 2012, p. 510).

In parallel with the poverty reduction challenge, the world has faced serious concerns on employment and widespread work deficits (ILO, 2012, 2015, 2016b, 2017). In 2012 alone, more than 1 billion people were either unemployed or living in poverty. Half of the job deficits were in more developed countries, 5 million in East Asia, 3 million in Latin America and the Caribbean, and 1 million in South Asia (ILO, 2012). Employment hardship is particularly severe among young people. In 2011, around 75 million youth aged 15-24 were unemployed, an increase of more than 4 million since 2007 (ILO, 2012). Youth residing in rural areas of developing countries are the most vulnerable, mainly due to their low level of education (ILO, 2015). An International Labour Organization (ILO) report showed that slightly over 30 per cent of youth in developing countries had "no education qualifications at all" (ILO, 2015, p. 26). Although educational attainment has been improved, too many young people are still neither employed, nor in education or training (ILO, 2016b). Hence, there has been a call to urgently address the global job crisis by recovering the market economy and generating job creation, especially for workers living below the US\$2 a day poverty line (ILO, 2012, 2015). 
Technical and vocational education and training (TVET) are seen as a solution to these challenges (Arthur-Mensah \& Alagaraja, 2013; Eichhorst, Rodriguez-Planas, Schmidl, \& Zimmermann, 2012; McGrath, 2002; McGrath \& Powell, 2016). TVET can provide skills, knowledge and attitudes that will prepare people for work, reduce poverty, and increase the economic growth of a country (UNESCO-UNEVOC, 2012). TVET is also regarded as "a skills development and training system for developing [the] workforce and addressing unique issues such as rural-urban migration, unemployment, declining job opportunities in the formal sector, as well as meeting the manufacturing demands" (Arthur-Mensah \& Alagaraja, 2013, p. 838). Crucially, “TVET shapes people's identity and people's [lives]. It empowers individuals to participate as active members of society" (UNESCO-UNEVOC, 2012, p. 6). Tikly (2013) further asserts that TVET does not only promote peoples' skills and knowledge needed for a country's economic development, but also their capabilities - the freedom of agency (what one values in life). Therefore, "TVET is steadily emerging as a winner in the 'race to the top' of global debates and government priorities for education and national development agendas" (Marope, Chakroun, \& Holmes, 2015, p. 11).

Where should education be the priority target in relation to poverty reduction? According to the United Nations Educational, Scientific and Cultural Organization (UNESCO), rural areas should be the priority (UNESCO, 2001). As UNESCO (2001, p. 1) states:

Goals set globally and by individual nations for education and development in the 21 st century cannot be realized without giving special attention to the situation of rural populations in developing countries... Greater emphasis should henceforth be given to developing the rural areas of poor nations [which] would require, fresh approaches to meeting the educational needs of rural populations.

TVET has pivotal roles in transforming the lives of rural populations. It can be seen as the production, as well as reproduction of their communities and society (Cavanagh, Shaw, \& Wang, 2013). As youth in rural areas of developing countries are facing unemployment, or engaging in low-paid jobs, TVET can help addressing these challenges, as well as building inclusive and sustainable societies (ILO, 2016b). Expanding TVET in rural areas is therefore essential, if rural transformation is to be met. 
In Laos, breaking the cycle of poverty has been the government's highest level of development priority. The National Growth and Poverty Eradication Strategy (NGPES), the localisation of PRSPs, was developed and published in 2004 , and education has been outlined as one of the four key development priorities to tackle poverty in the country (Lao PDR, 2004). Since then, several attempts have been made both by the government and its development partners (UCW, 2014). Over the past two decades, the poverty rate has halved from 46 percent in 1992/1993 to 23 percent in 2012/2013 (UNDP, 2015). However, its rate is high among indigenous peoples/ethnic groups who live in remote, isolated, and highland areas (Coulombe, Epprecht, Pimhidzai, \& Sisoulath, 2016), and the rate is highest among ethnic groups that belong to Mon-Khmer and Hmong-Lu Mien (UNDP, 2015). Working in an unproductive agriculture, caused by low human capital, is the main factor leading these people to be living in poverty (MPI \& UNDP, 2009; UCW, 2014; World Bank, 2014a).

Poverty, in the context of Laos, is defined as "the lack of ability to fulfil basic human needs such as not having enough food, lacking adequate clothing, not having permanent housing and lacking access to health, education and transportation services" (Lao PDR, 2004, p. 4). If 'the lack of ability to do something' in order to pursue one's own aspirations and needs is an issue, then education and training have an important role to play.

In Laos, ensuring citizens are equipped with skills and knowledge is mainly the responsibility of the Ministry of Education and Sports (MOES) (Noonan, Phommalangsy, \& Phetsiriseng, 2013). For MOES, TVET is regarded as an instrument for skills development, thus reducing poverty and accelerating the economic growth of the country (MOE, 2007b). The Ministry of Agriculture and Forestry (MAF) has a key role to improve rural livelihoods and ensure food security in the country. These goals are to be achieved by strengthening people's skills through TVET (MAF, 2008). Therefore, with the support of international development agencies, in 2007, both MOES and MAF have begun to reform TVET strategy to ensure that the previously stated objectives are met (MAF, 2008; MOE, 2007b). However, our understanding of the extent to which reform strategy is aligned with rural livelihoods is very limited. Although a few studies have been conducted in the past few years-UNESCO (2013) and World Bank (2013), for example - these concentrated too much on policy development at the national level, 
providing very little information in terms of the relevance of the policy and livelihoods.

The global and national challenges of tackling poverty, as well as the identified research gaps, have shaped the theme, aims and questions of my research. In a broad view, I am examining the relationship between education and development, with an emphasis on indigenous peoples. In particular, I look at the role of vocational education in supporting the livelihoods of rural youth in Luang Prabang province, situated in the northern region of Laos.

There are two reasons why I chose Luang Prabang as the research location. First, it has a long history. It is where the first Lao Lane Xang Kingdom (the Land of A Million Elephants) was founded, and where the indigenous people (Kmhmu, or Mon-Khmer ethnic groups) mostly reside (Evans, 2002; Stuart-Fox, 2008). Second, it offers larger vocational education institutions compared to other provinces in the region, and thus serves many youths from the provinces. Locations of the research include two vocational education colleges located in Luang Prabang city, and two villages situated in the rural, remote areas of the province. More about the vocational education institutions and study villages are explained in chapters 3 , 4 , and 5 .

\subsection{Research objectives and questions}

The central aim of this research is to examine the relevance of TVET to the livelihoods of rural youth in Luang Prabang province. It investigates the way in which rural people make their living, the decision-making of youth in pursuit of livelihood betterment, and the extent to which current TVET policy and interventions have helped, or can help support livelihoods of these people.

To respond to the aim of this research, a central question was developed: "How relevant is TVET to the current livelihoods and aspirations of rural youth in the Luang Prabang province?” In order to support the central question, three subquestions were also developed as follows.

1. How are the current livelihoods of local people arranged in Luang Prabang province?

2. What are the livelihood aspirations of rural youth in this province and what influences them? 
3. How do current potential TVET policy and interventions align with the current livelihoods and the aspirations of rural youth in Laos?

Note that the research topic, aims and questions were changed from the original plan. At first, the plan was to examine the influence of place on the perceptions of vocational education and the occupational aspirations of young rural ethnic groups in northern Laos. When re-examining the gathered information, I found the data pointed to a far stronger influence exerted by the concept of "livelihoods" rather than the concept of "place." I, therefore, changed the research topic, aims and questions accordingly.

\subsection{Research approach and methodology}

As the research is related to livelihoods and education, a sustainable livelihood approach with an emphasis on human capital and capabilities was employed in this research. Also, since the research dealt with people's perceptions, aspirations, personal life experiences, qualitative and ethnography were used as methodologies, and interviews, a focus group, and transect walks were used as a methods of data collection. A combination of the approach, methodologies and methods provided rich information for the analysis in this research.

\subsection{Research significance linking to development theory and practice}

This research has a significant link to development theory and debate around education, indigenous people, and development. It adds the question of what approach can best support indigenous peoples (Eversole et al., 2005). As ethnographic research, it provides insights into the real life experience of indigenous peoples, thus contributing to the debate around the concept of selfdetermination, livelihoods, and the resistance of indigenous peoples within the country as well as in the Asia region (Erni, 2008, 2015). It signals areas for further research, for example, how national and international policy development can more effectively support the livelihoods of indigenous peoples, especially youth. The research also links specifically to contemporary recommendations on the application of the 'capability approach' into TVET, and more broadly human development programmes (Powell \& McGrath, 2014; Tikly, 2013; UNDP, 2016). 


\subsection{Thesis outline}

This research consists of eight chapters. In general terms, chapters two to four provide the foundations of this research. Chapters five to seven provide analysis and discussion. Each of these chapters is organised based on the sub-questions of the research presented earlier. Finally, chapter eight provides the conclusion of the research. Details of each specific chapter are as follows.

Chapter 2 explains the relationship between education and development. It explores beyond the link between education and poverty reduction by looking at their relationships within economic growth, sustainable development, democracy and social justice. The chapter clarifies how the sustainable livelihood approach was used as an analytical framework in this research.

Chapter 3 explains the methodology used in this research. It details how the research was carried out, including clarification of the research locations, recruitment of participants, and methods of data collection and analysis. Considerations on human ethic issues and my positionality in the research are also presented.

Chapter 4 provides the context of Laos. It briefs the overall picture of the country, then moves to discuss specifically the development of TVET in the country, as well as the colleges I visited in Luang Prabang. Highlights in this chapter are the TVET development strategies and interventions provided by the government and its development partners. These are critical for the analysis in the research.

Chapter 5 provides answers to the first sub-question of the research. It explains how rural livelihoods in two visited villages are arranged. The chapter highlights what indigenous peoples in these villages do to make a living, how and why.

Chapter 6 considers the second sub-question of the research. It explores how youth perceive education as their choice of livelihood, how they make their choice towards educational paths, and what they aspire to for their livelihood betterment. The chapter also explains what constrains and what supports their pathway to education.

Chapter 7 responds to the third sub-question of the research. It brings all the findings, literature, and policy interventions discussed in the previous chapters together to examine the extent to which TVET has, or can, support livelihoods and 
the aspirations of rural youth in the research context. The chapter spells out the challenges TVET faces, and provides a potential solution to the challenges.

Chapter 8 concludes the research. It wraps up what has been discussed in the research and clarifies the extent to which it has responded to the questions posed. It then identifies some limitations of the research and areas that can be further investigated. 


\section{Chapter 2 Education, development and sustainable livelihoods}

\subsection{Introduction}

This chapter provides the theoretical background fundamental for the analysis and discussion in the subsequent chapters. It reviews the ideas around education, development, and sustainable rural livelihoods.

The chapter begins by exploring the link between education and development. It explains areas where education can promote development in terms of economic growth, sustainable development, democracy and social justice. It shows that the education-development relationship sometime has tensions, raising the question of purpose-education for whom and for what?

As the research focuses on TVET, the chapter also reviews areas where it can support development. Finally, the chapter explains the sustainable livelihood approach and how it will be used as an analytical framework for this research.

\subsection{Education and development}

The education and development relationship is a contested idea as "the nature and purpose of education, of development, and of the relationship between them" are viewed distinctively (McGrath \& Gu, 2016, p. 4). Education in itself is a complex and multi-faceted concept intertwined with many aspects of society-the social, economic, and political (Bailey, Barrow, Carr, \& McCarthy, 2010; Dufour \& Curtis, 2011). "Education is a changing, contextual and often highly personalised, historically and politically constructed concept" (Kevin Harris, cited in Curren, 2003, p. 221). Accordingly, the purposes of education are diverse, depending on how education is used: who should be educated and why? (Ames \& Hershock, 2008; Curren, 2003; Palmer, 2001; Pring, 2007; Turner, 2007). Similarly, there is no universal consensus on the definition of the term 'development' as its meaning 
evolves over time (Desai \& Potter, 2014; Pieterse, 2009). Development is generally understood as growth, evolution, maturation, and a process of change (Pieterse, 2009; Sachs, 2010). The relationship between them is, therefore, a complex and contested idea.

The relationship between education and development can be assessed at least in four different aspects: growth, sustainability, democracy and social justice.

First, education is regarded as human capital that can accelerate economic growth (Becker, 2009). Human capital refers to the skills, knowledge, and capabilities of the individuals (Blair, 2011). If individuals acquire knowledge and skills, then they will become key inputs for the production of goods and services, thus contributing to economic growth (Becker, 2009; Blair, 2011). Increased investments in education and training thus result in the increase of expected earnings of individuals, subsequently improving their living standards (Becker, 2009).

Moreover, in a place where agriculture is a primary means of production and consumption, human capital can play a fundamental role in agricultural production. As Becker (2009, p. 25) states, "education is of great value since it helps farmers adapt more quickly to new hybrids and other new technologies," resulting in more productive and profitable agricultural outputs. However, there is no guarantee that the input one invests in education will lead to a desired output. As Biesta (2013) asserts, economic growth can only be achieved if education systems and management are robust.

This growth model seems to be in favour of many policy makers, politicians, and organisations around the globe (Biesta, 2013). Therefore, they continue to invest in education. They "want education to be strong, secure, and predictable, and want it to be risk-free at all levels" so that the desirable results can be achieved (Biesta, 2013, p. 1). However, from a post-development theory perspective, economic growth can deteriorate the livelihoods and culture of local people (Escobar, 2000; Gibson-Graham, 2005; Pieterse, 1996, 2000). It can push people to rely on the market for their livelihood security which may not be a sustainable way of maintaining development.

Second, education can promote sustainable development. In this sense, the term is often regarded as education for sustainable development (ESD) which is viewed as an approach that "seeks to balance human and economic well-being with 
cultural traditions and respect for the Earth's natural resources" (Thakran, 2015, p. 55). ESD is perceived as a learning process in the pursuit of sustainability (Kassem, Mufti, \& Robinson, 2006). In achieving sustainability, youth shall be a key target in any form of education and any process it takes. As Thakran (2015) argues, ESD ensures young people are well-educated and trained so that they will be able to carefully consider and address any implication that may occur from social and economic activities, as well as political actions. Additionally, ESD must ensure that the obtained skills and knowledge are relevant to current national development needs, as well as livelihood sustainability and employment needs (Sarabhai, 2014). For Arbuthnott (2009), ESD shall aim not only at changing the attitudes and values of young people, but also at sustaining their livelihoods and living standards. For these reasons, it is argued that educaiton does not only play an essential role in fostering economic growth, but also in achieving sustainable development objectives (Buckler, 2014; Gerner, 2013).

Third, education can foster individuals' freedom, thus creating a democratic society. According to Biesta (2006, p. 123), "the most common way in which the relationship between democracy and education is understood, is one in which the role of education is seen as that of preparing children... for their future participation in democratic life." Democratic education is therefore, first of all, seen in classroom practice, rather than in an environment where advocacy and lobbying exist. Sullivan (1966) explains that democratic education ought to be carried out by using principle of life, by promoting freedom of and stressing individuality, and by learning selffirst-hand experiences. Garrison, Neubert, and Reich (2012) further assert that democratic education must be progressive and interactive within and between individuals, creating new knowledge from past experiences, and thus newly obtained knowledge contributes to communities and societies.

As democratic education focuses on classroom practice, the teaching method used must be a key instrument to help a child realise a democratic life. Dewey (1963) sees that teaching methods should be changed from the conservative to progressive approach, creating room for the development of critical thinking and real world problem-solving skills, and leading to scientific and pragmatic education (see also Pohoata \& Mocanu, 2015). Garrison et al. (2012) argue that recognising the importance of democracy in the teaching and learning process is essential in a 
modern education; thus, any education policy and intervention should include the notion of education as democracy, if the rights of individuals are to be promoted.

Finally, education is an instrument for social justice promotion. Education empowers individuals' rights, freedom, equality and equity (Newmann, 1985). In so doing, education should be developed with the concept of a locally-based rather than centrally-based approach (Newmann, 1985). The knowledge to be taught "must be formulated in response to particular, local circumstances through a process that connects teachers and students to their own cultural histories and that empowers them to define the curriculum" (ibid., pp. 4-5). As a result, education is more relevant to the needs of local people; the knowledge is re-constructed and owned by the local leaners.

Overall, it seems that there are tensions on how education is used. While a human capital approach concentrates on improving skills for the demand of the labour market that may bring about higher wages for individuals and benefits for employers, in turn, contributing to the economic growth (Harber, 2014), a sustainable development approach embraces a balanced-development model, arguing that development should create fewer negative impacts on the people, culture, and the planet. Also, development should be about protecting and sustaining resources (Elliott, 2006, 2013).

It seems that the purposes of education are also diverse. While some governments use it as a means to increase economic growth, others may see it as a means to promote individuals' freedom and social justice. For what purpose education is used, however, would depend on the political will and the socioeconomic needs of a nation. Because of these multifaceted factors, education is regarded as contextual, historical, and political, as observed by Kevin Harris (cited in Curren, 2003).

\subsection{TVET and development}

In the previous section, I have examined the link between education and development in a broad aspect. This section, in turn, looks specifically at the link between its subsector - technical and vocational education and training (TVET) and development. 
According to Karmel (2010, p. 229), TVET is characterised as "the most diverse education sector, least understood, and poorly defined." What and how to teach varies across nations, depending on their contexts and socio-economic development needs (Gonczi \& Hager, 2010; Karmel, 2010). Arrangements of TVET in terms of structure and setting are flexible in that they can be delivered not only in the classroom, but also in the workplace within a country, as well as in international institutions (Karmel, 2010).

The TVET offered varies across nations. In some countries, TVET programmes are provided at higher levels of education which means that only students who have completed at least secondary education can attend. In other countries, they are offered at the secondary level of education which means that students who have completed their primary education can also attend (Eichhorst, Rodríguez-Planas, Schmidl, \& Zimmermann, 2015).

Teaching and learning in the context of TVET is practical and specifically field-oriented, thus learners acquire skills and knowledge for specific and practical activities (Gonczi \& Hager, 2010). Competency and apprenticeship models are applied particularly in this form of education (Eichhorst et al., 2015; Gonczi \& Hager, 2010; Smith, 2010). Apprenticeships consist of two forms: formal apprenticeships and dual cooperative training systems (Eichhorst et al., 2015; Smith, 2010). The formal apprenticeships are often solely provided by either educational institutions, or at the workplace. The dual systems are provided through collaboration and involve various institutions, including the government, companies, and charitable organisations (Eichhorst et al., 2015). Because of these characteristics, TVET is unique and differs from general education (Karmel, 2010).

At a global scale, UNESCO takes a leading role in promoting TVET for development (Fien, Maclean, \& Park, 2009). TVET is viewed as a key to alleviating poverty, promoting peace, conserving the environment, improving the quality of life for all and ensuring sustainable development (Fien et al., 2009). It is also regarded as a means to ensure people are equipped with the knowledge, competencies, skills, values and attitudes to become productive and responsible citizens who appreciate the dignity of work and contribute to sustainable societies (Fien et al., 2009). Importantly, TVET can enhance individuals' quality of life by: 
enlarging [their] choices in life; enabling them to lead a long and healthy life; to acquire knowledge through education and training; to enjoy a secure and peaceful environment where there is personal security; to have the resources needed for a decent standard of living; and to achieve equality and fairness for all men and women, while preserving the environment for future generations. (Fien et al., 2009, p. xxiii).

TVET can also promote sustainable development. The International Centre for Technical and Vocational Education and Training of the United Nations Educational, Scientific and Cultural Organization (UNESCO-UNEVOC) defines TVET for sustainable development as a process of development that can bring about change on the long-term future of the economy, ecology and society. In other words, TVET promotes economic sustainability, environmental sustainability, and social sustainability (Fien et al., 2009). To ensure sustainable development, McGrath and Powell (2016) argue that TVET should incorporate the notion of human development, and that these should be seen as inseparable. They also argue that TVET must be concerned with poverty, inequality and injustice, as well as supportive of individuals' agency.

We can see that TVET has a fundamental role to play in supporting the livelihoods of individuals, and in promoting economic growth, sustainability, democracy and social justice. Therefore, it can be argued that TVET is just as important as general education, as explained earlier.

\subsection{Sustainable livelihood approach}

In the first half of the chapter, I have shown how education can promote development. In this second half, I explain the sustainable livelihood approach (SLA) which will be used as an analytical framework for this research. First, I provide the definition and explain the elements of the SLA. Then, I explain how it will be used in this research.

\subsubsection{The definition and components of sustainable livelihoods}

The sustainable livelihood approach stems from the notion of rural development which had gradually evolved in previous decades (Ashley \& Maxwell, 2001). In other words, SLA was built upon the lessons learned after the emergence of rural 
development (Carney, 1999): instead of considering only agriculture as a key factor for rural growth, the sustainable livelihood approach looks beyond the farm-based and towards non-farm-based growth factors (Ellis \& Biggs, 2001). Also, SLA is a subset of the sustainable development notion. SLA brings the objectives of sustainable development into practice (Morse \& McNamara, 2013).

Chambers and Conway (1992, p. 6) define sustainable livelihoods as follows:

A livelihood comprises the capabilities, assets (stores, resources, claims and access) and activities required for a means of living; a livelihood is sustainable when it can cope with and recover from stress and shocks, maintain or enhance its capabilities and assets, and provide sustainable livelihood opportunities for the next generation; and which contributes net benefits to other livelihoods at the local and global levels and in the short and long-term.

SLA puts people at the centre of development activities, works with the people who own the livelihoods, and builds upon their own strengths to realise their potential (Carney, 1999). It seeks to identify "what the poor have, rather than what they do not have, ...[and to] strengthen people's own inventive solutions, rather than substitute for, block or undermine them" (Moser, 1998, p. 1). Therefore, the notion of human capabilities becomes crucial in the study of livelihoods. The idea of human capabilities is derived from Sen $(2001,2005)$. The human capabilities refer to as "being able to perform basic functionings, to what a person is capable of doing and being" (Sen and Dreze, cited in Chambers \& Conway, 1992, p. 4).

Concentrating on the people as central to development is a concern in this research. While acknowledging the importance of human capital (knowledge and skills), I consider what humans (here, youth) value in life, what they aspire to for life betterment, and more precisely, what they want to do and be. Understanding the aspirations of youth, especially those from impoverished family backgrounds, can help unpack their strengths and potential for development. As Conradie and Robeyns (2013, p. 559) argue, "working on aspirations of the poor can play an important role in an anti-poverty strategy." Also, within psychological disciplines, aspiration is viewed as a tool to accelerate individuals' goals in life, both in academic and professional settings (see Duckworth, 2016; Duckworth \& EskreisWinkler, 2015; Duckworth \& Gross, 2014; Powell, 2012). Therefore, 
understanding the aspirations of the poor, especially in an education setting, is essential for education policy-making (Hart, 2013).

Livelihood assets are comprised of five capitals: human capital, natural capital, social capital, physical capital, and economic or financial capital (Ellis, 2000; Morse \& McNamara, 2013). Each of the capitals is described in Table 2.1.

Table 2.1 Livelihood assets and elements

\begin{tabular}{ll}
\hline Livelihood assets & Elements \\
\hline Human capital & $\begin{array}{c}\text { Skills, knowledge, labour (includes good health and physical } \\
\text { capability) }\end{array}$ \\
Natural capital & $\begin{array}{c}\text { Natural resource stocks (soil, water, air, genetic resources etc.) } \\
\text { and environmental services (hydrological cycle, pollution }\end{array}$ \\
& sinks etc.) \\
Economic or & $\begin{array}{c}\text { Capital base (cash, credit/debt, savings, and other economic } \\
\text { ansets) }\end{array}$ \\
Physical capital & $\begin{array}{c}\text { Infrastructure (buildings, roads), production equipment and } \\
\text { technologies) }\end{array}$ \\
Social capital & $\begin{array}{c}\text { Social resources (networks, social claims, social relations, } \\
\text { affiliations, associations) }\end{array}$
\end{tabular}

Source: Author, adapted from Scoones, cited in Morse and McNamara (2013, p. 28).

\subsubsection{Sustainable livelihoods as an analytical framework}

A sustainable livelihood approach can be used as a framework for analysis in development research, as well as for development planning (Morse \& McNamara, 2013; Scoones, 1998). In development research, it is used to analyse 'what is' happening and 'what can be' done better. The analysis is often taken at the grassroots level, and the unit of analysis can be individuals, households, or communities. The results of analysis can then inform development policy-makers, planners, and researchers. In development planning, the approach is used to help community members to development a plan of action. Therefore, it is considered as a practical tool to maximise the effectiveness of development interventions, and is employed by researchers and development practitioners in their respective activities (Morse \& McNamara, 2013).

Guided by the work of Scoones (1998) on sustainable livelihood frameworks, Sen (2005) on human capabilities, and Becker (2009) on human capital, I adapted 
a sustainable livelihood framework that serves specifically the purpose of this research, as shown in Fig. 2.1.

Fig. 2.1 A sustainable rural livelihood analysis framework

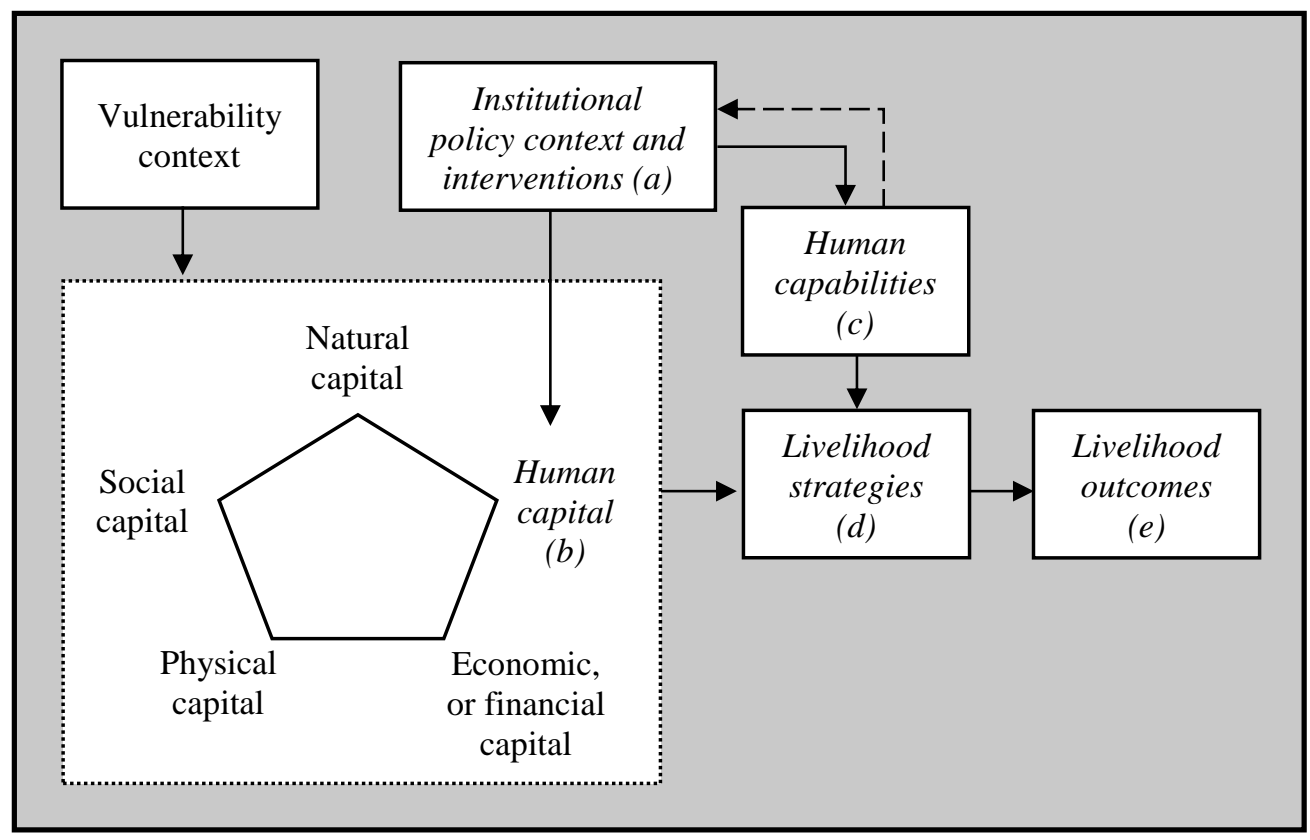

Sources: Author, adapted from Scoones (1998, p. 4); Morse and McNamara (2013, p. 19)

This research focuses on five components. These are (a) the institutional policy context and interventions, (b) human capital, (c) human capabilities, (d) livelihood strategies, and (e) livelihood outcomes. I want to analyse how component (a) affects components (b) and (c), as well as how component (c) interacts with component (a). Finally, I will observe how components (a), (b), and (c) help improve components (d) and (e).

Other components such as natural capital, social capital, physical capital, and economic capital, as well as the vulnerability context, will only be discussed where issues emerge from the fieldwork. Analysing these elements requires a unit of analysis, either as a household or individuals.

\subsubsection{Individuals and household as units of analysis}

Acceding to Owusu (2009), the traditional analysis of livelihoods has given much attention to the household level. However, this limits the extent to which the researcher may fully understand broader aspects of livelihood systems. Consequently, many livelihood studies have turned their focus to include both "the 
household and its individual members as units of study" (Owusu, 2009, p. 221). By definition, a household is understood as "a social group which resides in the same place, shares the same meals, and makes joint or coordinated decisions over resource allocation and income pooling" (Owusu, 2009, p. 221), and individuals refers to the members of a household.

In this research, I apply both household and individuals as units of analysis. The analysis stresses the importance of deconstructing the household decisionmaking process by looking specifically at the context of education. Negotiations made between rural youth who wish to follow their dreams and others in their household, specifically parents, who may or may not support their children's aspirations, are critically analysed in this research. This is critical as we cannot assume that a household's decisions reflect the consensus of all its members (Owusu, 2009).

Also, this analysis is not limited by the exclusion of external factors affecting people's livelihoods and decision making, such as social networks and cultural norms (social capital), household economic status (economic capital), natural capital, vulnerability, and policy interventions. Presumably, these factors are critically important towards how individuals and households make decisions for their own livelihoods.

\subsection{Summary}

Overall, I have shown that the relationship between education and development is a contested idea. Education can support development in many aspects, including poverty reduction, economic growth, sustainable development, democracy and social justice. However, the relationship between them seems more explicit in theory, and less explicit in practice.

Education has multiple-purposes, and how it is used by the government in a country differs, depending on social, economic, and political needs. This raises a fundamental question: for whom, and for what purpose, does education serve? An assessment of how education promotes development, especially the way in which TVET supports the livelihoods of rural people in a Least Developed Country (such as Laos), can enhance our understanding of the multi-purposes of education. 
In this chapter, I have also explained how a sustainable livelihood approach can be used to analyse the education-development relationship in Laos. Human capital and capabilities are key components of the analysis. Individuals and households are regarded as units of analysis in this research. Using the sustainable livelihood approach to analyse what TVET policy offers and what is needed the local level is critical as it will help unpack the development gap, thus informing development policy.

The next chapter explains how the sustainable livelihood approach informs the choice of applying the epistemology and methodologies used in this research, as well as how the research was carried out in the fieldwork. 
This page intentionally left blank 


\section{Chapter 3 \\ Research methodology}

\subsection{Introduction}

The previous chapter explained the approach employed in this research. This chapter expands on this by explaining how such an approach informs the methodology used in this research, and how the research was carried out in practice. The chapter also clarifies the recruitment of participants, the locations of the research, and the analysis of data. The explanations provided in this chapter are essential to understand before reading the findings presented in the subsequent chapters.

\subsection{Social constructivist epistemology}

The term epistemology, a branch of philosophy, is derived from two words 'episteme and logos' in Greek, meaning knowledge and explanation respectively. Epistemology is the study of the nature of knowledge and the process of how the knowledge is acquired-how do we know what we know? (Stone, 2008). Epistemology is concerned with justification of beliefs - what we think to be true (Hull, 2015). It tells us how we come to have legitimate knowledge of the world and what rules might be needed in order to produce knowledge (O'Leary, 2007).

This research employed social constructivist epistemology, which sometimes refers to dialectical constructivism (Applefield, Huber, \& Moallem, 2000; Gergen, 2013). Social constructivism can be broadly defined as a belief that things are produced and reproduced, or constructed and reconstructed by social actions through the intersection of people that involves information sharing, comparing, contrasting, and debating within and between social group members (Applefield et al., 2000; Detel, 2015). When we share, compare, and debate, we rely on our beliefs and facts, resulting from our own experience in both our daily life and educational setting (Detel, 2015). As Applefield et al. (2000, p. 36) put it, "through a highly 
interactive process, the social milieu of learning is accorded centre stage and learners both refine their own meanings and help others find meaning. In this way, knowledge is mutually built." Thus, it can be said that learning never occurs without interacting with others.

As the sustainable livelihood approach concentrates on people and their culture, it has informed the choice of applying a social constructivism epistemology in this research. In social constructivism, language plays a significant role. I would not have acquired the understandings of the participants without having communication with them through the use of languages and expressions, verbally and physically. As Biesta $(2006,2013)$ notes, language is a key element to ensure that learning and knowledge sharing occur. Lev Vygotsky claims that "language enhances learning and precedes knowledge or thinking" (Powell \& Kalina, cited in McComas, 2014, p. 99). Language is vital as it helps learners receive information and make meanings out of it. It functions as a mediator between learners, shaping and extending their thoughts. For instance, when learners exchange their ideas through the use of language, they become thinkers and thus produce knowledge (Jeannine St. Pierre, 1996). For Burr (2015), language and knowledge are not two separate phenomena. Rather, it is the language that provides the basis of all our thought.

In this research, I consider myself and the participants as learners through the use of language. The language used in this research, whether Lao national or indigenous languages, played a fundamental role in how we conveyed the meanings and facts that each of us believed to be true. Language also demonstrated how each of us interpreted things from our own perspectives, discourses, and experiences. Language was not only important for how we learned with and from others, but for how we created meaning from our own experiences. Using social constructivist epistemology has, therefore, helped me to understand what and why people think and do things, and what they value in life.

To understand how things are socially constructed requires a qualitative and ethnographic research methodology, as such a methodology allows the researcher to investigate what is being studied from a broader worldview, rather than confined by its own narrow one (Creswell, 2014). 


\subsection{Qualitative and ethnography methodologies}

Informed by social constructist epistimology, qualitative and ethnography methodologies were employed in this research. Such methodologies open the floor for the participants to freely express their worldviews and share their lived experiences which they had acquired historically, culturally, and socially (Creswell, 2014).

As suggested by ethnography (Crang \& Cook, 2007), the three months I spent on fieldwork helped me to gain an understanding of not only what the research particpants did, but also how and why they did so. Working as an ethnographic researcher also means that I lived, interacted, and experienced the daily patterns of the participants (Madden, 2010). Using ethnography is beneficial in that it helped me learn throughout the process of doing this research. As qualitative and ethnographic research is an open-ended form of questioning (Crang \& Cook, 2007; Creswell, 2014), it created the space for me and the participants to explore the questions underpinning my research and begin to formulate answers in response.

In this research, I employed three different methods in order to gain data required for qualitative and ethnography: interviews, a focus group, and transect walks. Before explaining how each of these methods were used, the following section firstly explains the participant recruitment, locations of research and the research timeline.

\subsection{Recruitment of participants, locations, and research timeline}

\subsubsection{Participants}

Selection of participants was developed with the aim of including a wide range of people, regardless of ethnicity, gender, age, level of education, and professional experiences. It was a non-random selection process which means that the participants were consciously considered and purposefully selected based on the characteristics of their institutions, geographical origins, and their fields of expertise or the relevance of questions to be asked (Kumar, 2014). I was mindful in that participant selection should be flexible and manageable within the framework of qualitative methodology (Creswell, 2014).

Guided by the above explanation, 24 participants were chosen for interviews and 10 youth participants for a focus group (Table 3.1). This number is counted by 
the time of activity conducted. If the actual number is to be counted, there were 32 participants instead of 34. As shown in Table 3.1, 10 youths participated in the focus group, and 2 out of the 10 were then selected to be interviewed. This means that the total actual number of youths from LPB-TVET was 11, instead of 13.

Table 3.1 Number and percentage of participants

\begin{tabular}{|c|c|c|c|c|c|}
\hline \multirow[t]{2}{*}{$\begin{array}{l}\text { Village/ } \\
\text { institution }\end{array}$} & \multirow[t]{2}{*}{ District } & \multirow[t]{2}{*}{ Province } & \multirow[t]{2}{*}{$\begin{array}{l}\text { Position of } \\
\text { participants }\end{array}$} & \multicolumn{2}{|c|}{$\begin{array}{l}\text { No. of } \\
\text { participants }\end{array}$} \\
\hline & & & & Total & Female \\
\hline \multirow{3}{*}{$\begin{array}{l}\text { Huayman } \\
\text { village }\end{array}$} & \multirow[t]{3}{*}{ Phonxai } & \multirow{3}{*}{$\begin{array}{l}\text { Luang } \\
\text { Prabang }\end{array}$} & Village head & 1 & 0 \\
\hline & & & Elder & 1 & 0 \\
\hline & & & Community member & 1 & 0 \\
\hline $\begin{array}{l}\text { Phonxai } \\
\text { village }\end{array}$ & Phonxai & $\begin{array}{l}\text { Luang } \\
\text { Prabang }\end{array}$ & $\begin{array}{l}\text { Secondary school } \\
\text { teacher }\end{array}$ & 1 & 0 \\
\hline \multirow[t]{3}{*}{ Ngoy village } & \multirow[t]{3}{*}{ Ngoy } & \multirow{3}{*}{$\begin{array}{l}\text { Luang } \\
\text { Prabang }\end{array}$} & Elder & 2 & 1 \\
\hline & & & Community member & 1 & 0 \\
\hline & & & School leaver (youth) & 1 & 0 \\
\hline \multirow[t]{4}{*}{ LPB-TVET } & \multirow{4}{*}{$\begin{array}{l}\text { Luang } \\
\text { Prabang }\end{array}$} & \multirow{4}{*}{$\begin{array}{l}\text { Luang } \\
\text { Prabang }\end{array}$} & Director & 1 & 0 \\
\hline & & & Teacher & 1 & 0 \\
\hline & & & Youth & 3 & 2 \\
\hline & & & Youth (focus group) & 10 & 4 \\
\hline \multirow[t]{2}{*}{ NAFC } & \multirow{2}{*}{$\begin{array}{l}\text { Luang } \\
\text { Prabang }\end{array}$} & \multirow{2}{*}{$\begin{array}{l}\text { Luang } \\
\text { Prabang }\end{array}$} & Director & 1 & 0 \\
\hline & & & Educators & 3 & 1 \\
\hline SU & $\begin{array}{l}\text { Luang } \\
\text { Prabang }\end{array}$ & $\begin{array}{l}\text { Luang } \\
\text { Prabang }\end{array}$ & Youth & 3 & 2 \\
\hline GIZ & & Vientiane & National expert & 2 & 1 \\
\hline World Bank & & Vientiane & Education specialist & 1 & 0 \\
\hline MOES & & Vientiane & Government official & 1 & 0 \\
\hline \multicolumn{4}{|l|}{ Total } & 34 & 11 \\
\hline \multicolumn{4}{|c|}{ Average percentage of female } & & 32.35 \\
\hline
\end{tabular}

Note: LPB-TVET = Luang Prabang TVET; NAFC = Northern Agriculture and Forestry College; $\mathrm{SU}=$ Souphanouvong University; NGO = Non-government origination (HELVETAS); GIZ = Deutsche Gesellschaft für Internationale Zusammenarbeit. MOES = Ministry of Education and Sports

Source: Author (2017)

Participant recruitment was not an easy task. Selection criteria were set to ensure gender balance, yet only slightly more than 30 percent of research participants were female. The biggest challenge was when choosing participants at the village level, although I received help from village heads. Key reasons were 
associated with the belief that men were more capable than women, especially in providing answers to the researcher. I had a hard time negotiating this matter.

At school, I received great support from teachers and the directors in terms of participant selection. We discussed who should be invited. In response to the purpose of this research, priority was given to rural youth, especially females and those from ethnic groups residing in rural villages of Luang Prabang and other provinces in the northern region of Laos. We also chose youth from different school years (from year 1-3). The intention was to ensure the inclusion of diversity such as gender, ethnicity, age, educational level, and place of origin.

In total, 14 youths participated in the research project, including 11 from LBP-TVET and 3 from Souphanouvong University. I included participants from university to provide voices as outsiders to TVET. Selected information of participants is presented in Fig. 3.1 below.

Fig. 3.1 Participants (youth) by gender and ethnic group

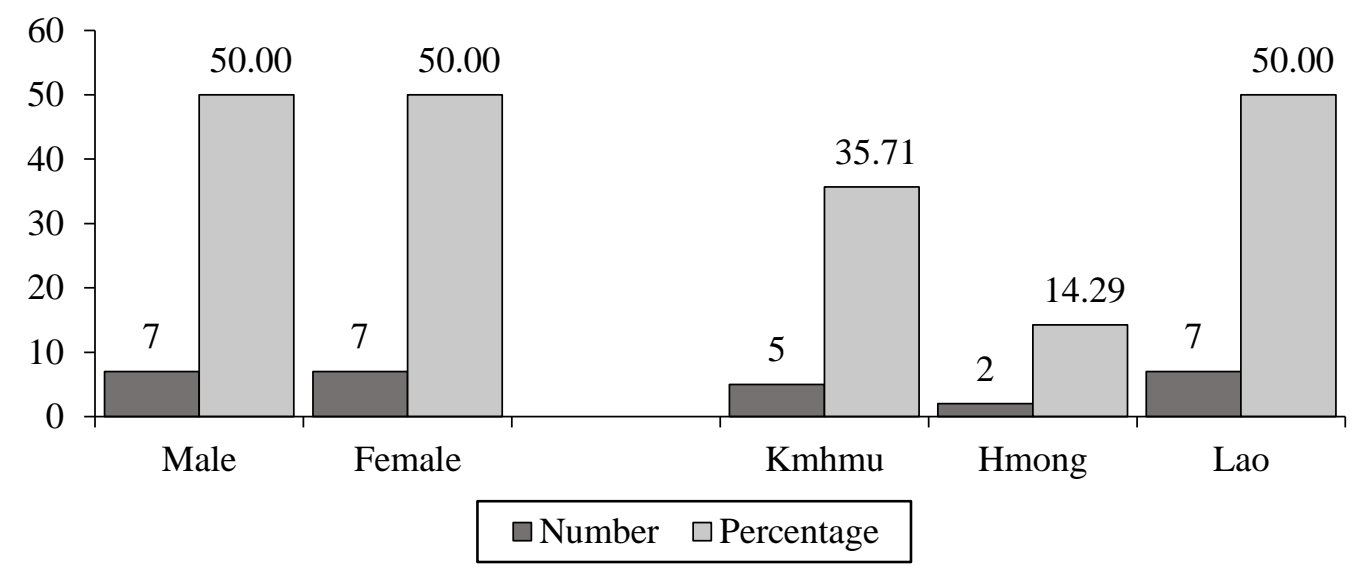

Source: Author based on interviews and a focus group

We can see that, by gender, an equal proportion of male and female youth were engaged in this research project. By ethnic group, half of the participants were Lao, and the other half were Kmhmu and Hmong. If youth participants by school year is to be calculated, there were 3 from year 1, 8 from year 2, and 3 from year 3 . The variation of gender, ethnicity, and education shows the complexity of youth voices in this research. 


\subsubsection{Locations}

I visited two colleges situated in Luang Prabang city: Northern Agriculture and Forestry College (NAFC) and Luang Prabang Technical and Vocational Education and Training (LPB-TVET) (Fig. 3.2). I chose them because they provide different types of skills: NAFC provides skills related to the agricultural sector, and LPBTVET provides skills related to the industrial and service sectors (chapter 4 provides more information about these colleges). Including these various sectors has provided rich information for my analysis.

I also visited two rural villages in two districts of Luang Prabang province (Fig. 3.2). I selected the villages based on the types of skills provided by the two colleges. Ban (village) Huayman, Phonxai district, was chosen because many people in the village rely on agricultural activities for their livelihood. Ban Meuang Ngoy was chosen because the majority of people in the village rely on tourism to make a living (chapter 5 provides more information and livelihood analysis of these villages). This provides me with a clear picture when analysing the skills that TVET offers compared with what skills are required in the rural areas. 
Fig. 3.2 Research locations in Luang Prabang province

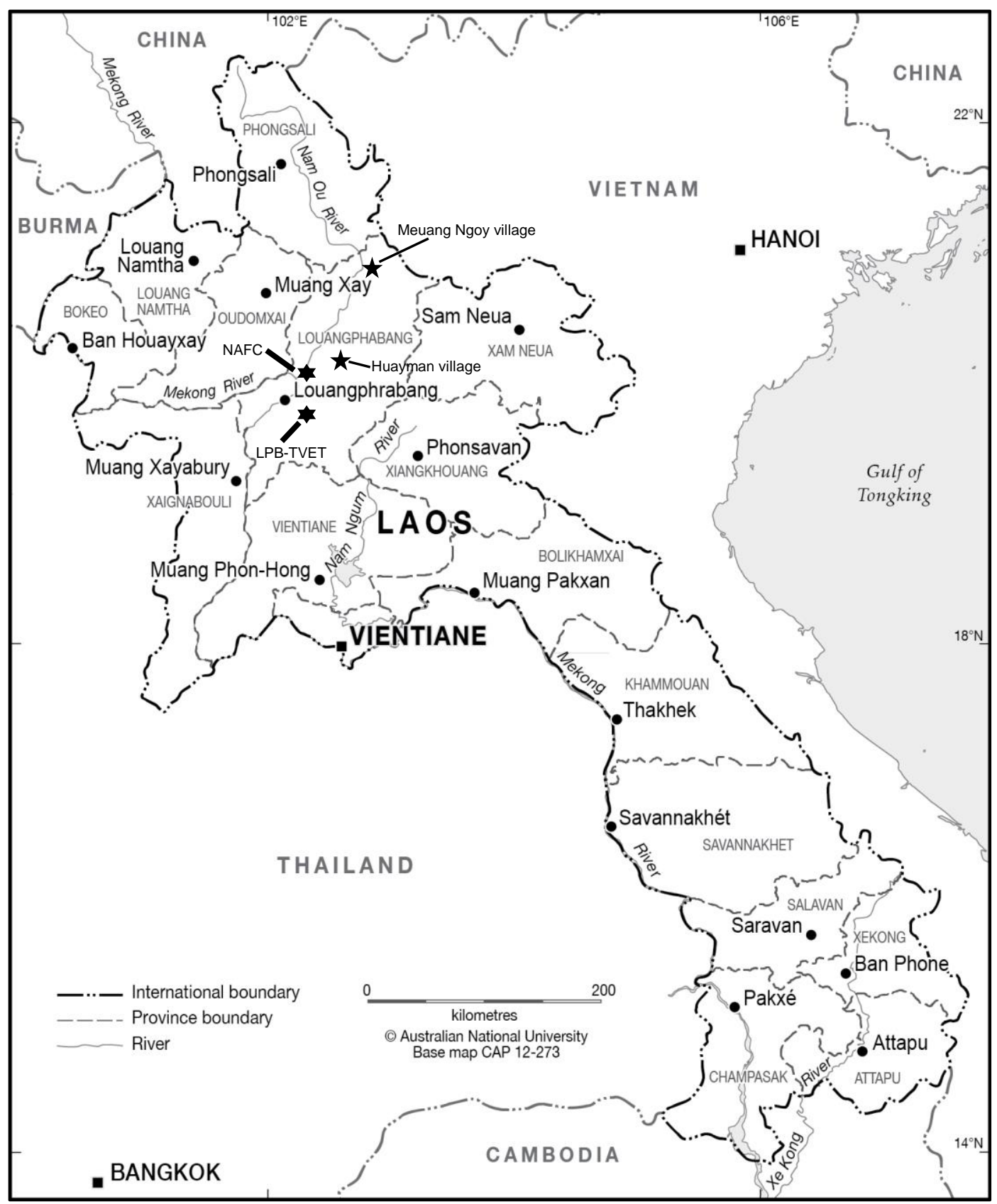

Note: NAFC $=$ Northern Agriculture and Forestry College; LBP-TVET $=$ Luang Prabang Technical and Vocational Education and Training.

Source: Australian National University (2012).

After the fieldwork in Luang Prabang, I went down to Vientiane, the capital city of Laos. People were selected for interviews from three institutions: The Ministry of Education and Sports (MOES), Deutsche Gesellschaft für Internationale Zusammenarbeit (GIZ), and the World Bank. MOES and GIZ were chosen because they support two colleges I visited. The World Bank was chosen because it has been supporting education development and research in Laos. 
Hearing the voices of participants from local to semi-national (college) and national levels has provided insights into the research topic, as well as allowing the advantages of comprehensive data analysis.

\subsubsection{Timeline}

This research took fifteen months to complete (Fig. 3.3). I spent three months designing research, preparing the research proposal, and applying for VUW Human Ethics Committee approval. Advance coordination with participants was also made before setting out upon the fieldwork. I then took three months working in the field: two months in Luang Prabang and nearby villages, and one month in Vientiane. My intention was to have a long stay, allowing me to collect information in more detail and in-depth, as ethnography suggests (Crang \& Cook, 2007). The remaining time was spent for data analysis and writing up the thesis which was mainly at the university campus.

Fig. 3.3 Research timeline

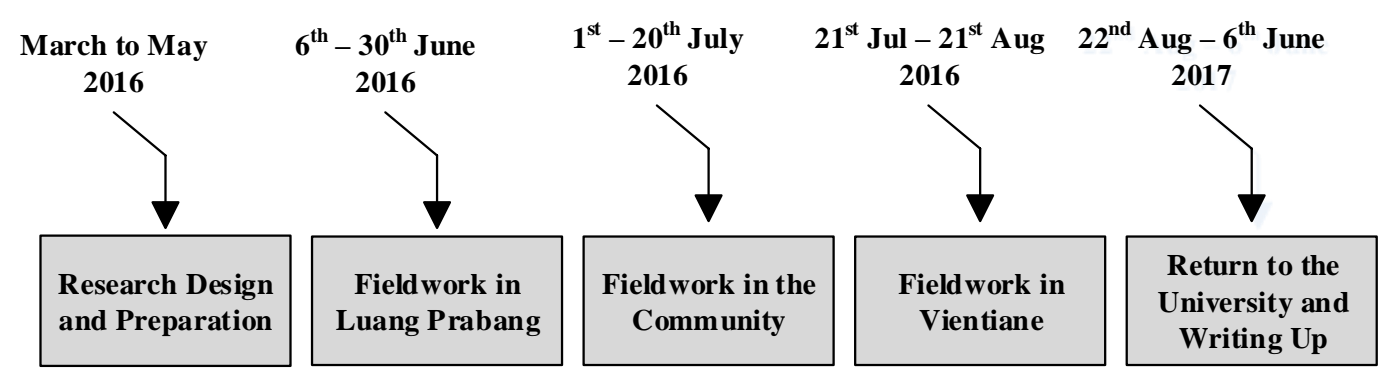

Source: Author (2017).

\subsection{Research methods}

Semi-structured interviews, a focus group and transect walks were used as methods in this research. Each of these methods is presented below.

\subsubsection{Semi-structured interviews}

I used the semi-structured interview method because it suits my research methodologies and my situation as a Masters student who had only three months to do the fieldwork. The method suits the chosen methodologies in that it allows openended questions, in turn allowing participants to interpret the questions being asked 
in broader respects, and therefore to give answers from various angles (Fife, 2005). The interview usually begins with the interests of the researcher and can be ended once the planned questions are answered (Fife, 2005). As such, using the method was not time consuming, allowing me to complete the fieldwork as planned.

The setup of the interviews during the fieldwork varied, depending on the situation of each individual participant. The interviews were conducted in the form of an informal discussion to encourage participants to be relaxed, friendly, and engaged in the discussions. Detailed interview procedures and schedules are attached in Appendices 1.1 to 1.4, 2.1 and 3.1. The language used for the interviews depended on whether the participants preferred to use their native (Kmhmu) or Lao language. As I speak both Kmhmu and Lao, there was no language barrier during interviews. The interviews took approximately 45 to 120 minutes.

As noted in Table 3.1, participants were local people, students (youth), educators, development workers, and government officials. Interviews of local people were organised at the participant's house and community hall. However, doing interviews at participants' houses were uncomfortable; interruptions from other household members could occur anytime, and sometimes our discussion was discontinued. Avoiding interviews at participants' houses could be a lesson learned for future fieldwork, especially when doing ethnography research.

Interviewing with students took place at their schools - an open place and space. Some were interviewed after their classes and others on the weekend, depending on their availability. I was flexible with the participants because, when the fieldwork took place, they were preparing for exams.

The interviews with school administrators, government officials, and development workers were conducted in more formal settings. I had to prepare official letters of request, attached with information sheets and research questions, which were sent before the meetings were arranged. I then followed up to make sure our availability suited and did not overlap with other interview arrangements. These arrangements are essential for a researcher (Crang \& Cook, 2007).

There was a change in how the interviews were arranged. My plan was to have only one-to-one interviews. However, there were two cases in which unexpected participants were willing to join. These interview settings, then, ended up as group interviews. As a result, each case took approximately 120 minutes. This seems to be unusual, but I was glad that all participants were engaged in the 
discussions. Crang and Cook (2007) note that the case is common in doing research fieldwork.

\subsubsection{Focus group}

A focus group was also conducted in this research (procedures and activities of the focus group refer to Appendices 1.5, 2.2, and 3.2). I used this as a strategy to gain the collective information of individuals, and to explore the attitudes, opinions, and perceptions of people towards a particular issue in a free and open manner (Kumar, 2014). The activity helped explore and learn about the thinking process and feelings of young people when they interacted, discussed, and debated the topics among themselves (Crang \& Cook, 2007). Such an interaction creates multiple dimensions of the topics being discussed.

In conducting the focus group activity, I employed a MetaCards ${ }^{2}$ approach. This approach is a powerful and practical tool to explore participants' ideas and imagination. Through my work with Plan International, an NGO, I have experienced the effectiveness of using this tool in education project design and evaluation. Therefore, I decided to employ it in this research.

Youth participants were asked to firstly express their aspirations through writing on MetaCards, answering a series of questions: (1) what do they want to do and be in the next five years? Then, they were asked to (re)-consider: (2) what do they already have as their assets? And finally, they were asked to explore or imagine: (3) what is needed to help them achieve their dreams?

In order to create a friendly environment while conducting the activities, I used the image of a 'River' as an analogy. What youth already have as their assets (question 2) was placed on one side of the River, while the other side of the River represented where they aspire or want to get to (question 1). To cross the River, participants may need tools and resources, such as skills, knowledge, or other forms of capital (question 3).

In using MetaCards, participants could freely express their ideas on the Cards and then pick and choose only what they thought relevant to the crossing 'River' flipchart regarding the questions being asked. As such, the MetaCards approach

\footnotetext{
${ }^{2}$ The MetaCards approach is applied in various kind of activities and is particularly used in development projects for project design and evaluation. See more on http://www.metacards.eu/.
} 
helped participants reflect on or explore their aspirations, and consider new possibilities that could help them successfully achieve their dreams. Figure 3.4 below illustrates the crossing River activity that we conducted.

Fig. 3.4 Focus group activity: A 'MetaCards' approach

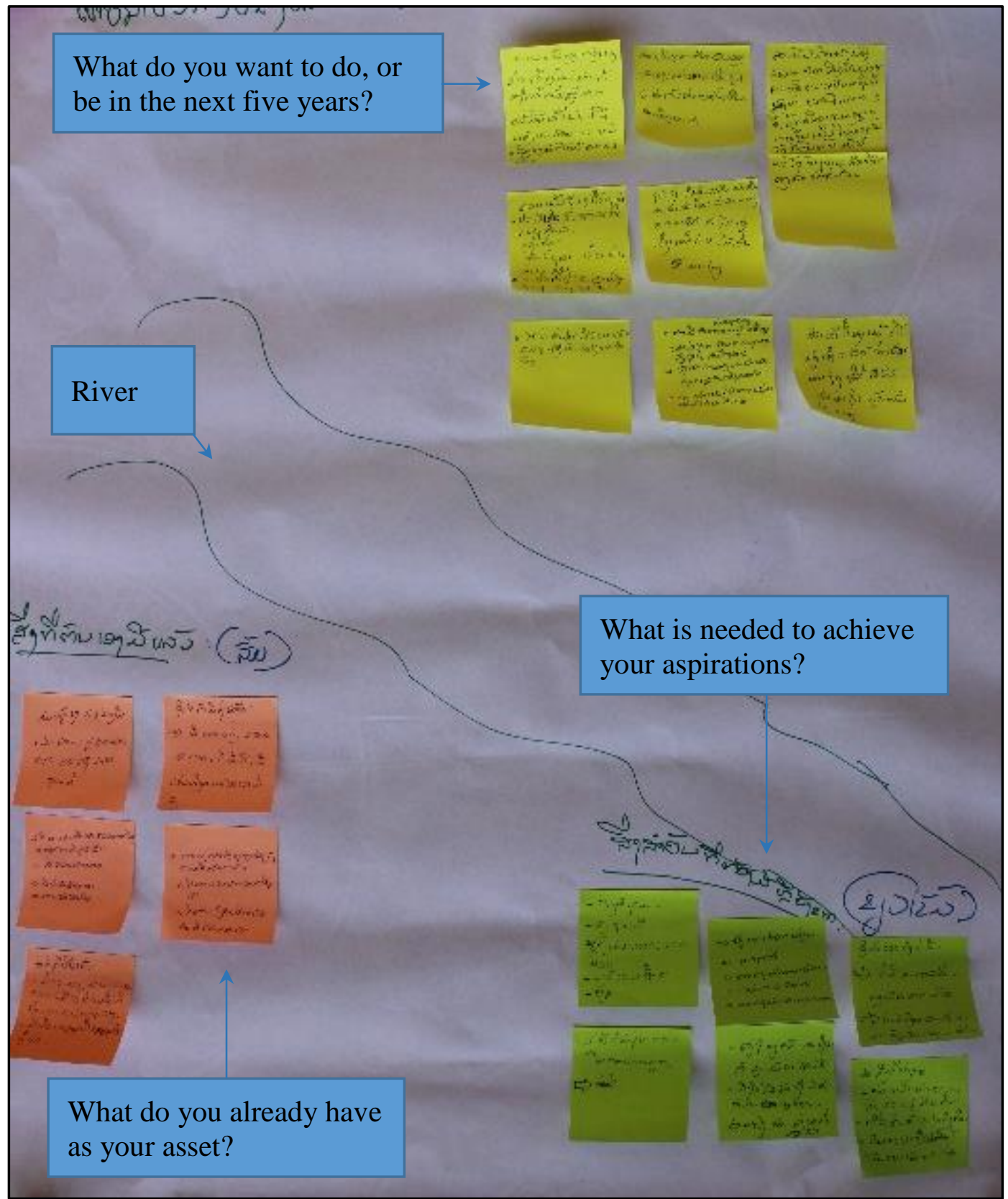

Source: Focus Group, 15/6/2016

There were 10 youths who participated in this activity, from different provinces of the northern region. Chapter 6 unpacks the above local language and analyses responses. 


\subsubsection{Transect walks}

Transect walks were used in addition to the interviews and focus group activity. The method was a practical and useful tool to identify locations and resources available in the community, such as the distribution of resources, land use, and physical features (World Bank, n.d). Guided by the practical instruction of the World Bank (n.d), the transect walk activity was conducted in a systematic way. Firstly, I identified the purposes of the activty. Then, with the assistance of village heads, I chose community members who knew about the locations and their historical background. Finally, I planned with them where to go and what to see.

Transect walks (see Appendix 3.3) were conducted in the two visited villages: Ban Huayman in Phonxai district, and Ban Meuang Ngoy in Ngoy district, Luang Prabang province. At first, I took a leading role in how to conduct the activity. Then, the participants guided and explained what we saw, what activities people did and why they did them. The activity has enriched my understanding of livelihoods in the two villages which I present in chapter 5 . One product from conducting the activity was the development of community asset maps (Fig. 3.5 and 3.6). The findings presented in chapter 5 were partially depicted from these two maps too. 
Fig. 3.5 Community asset map of Ban Huayman

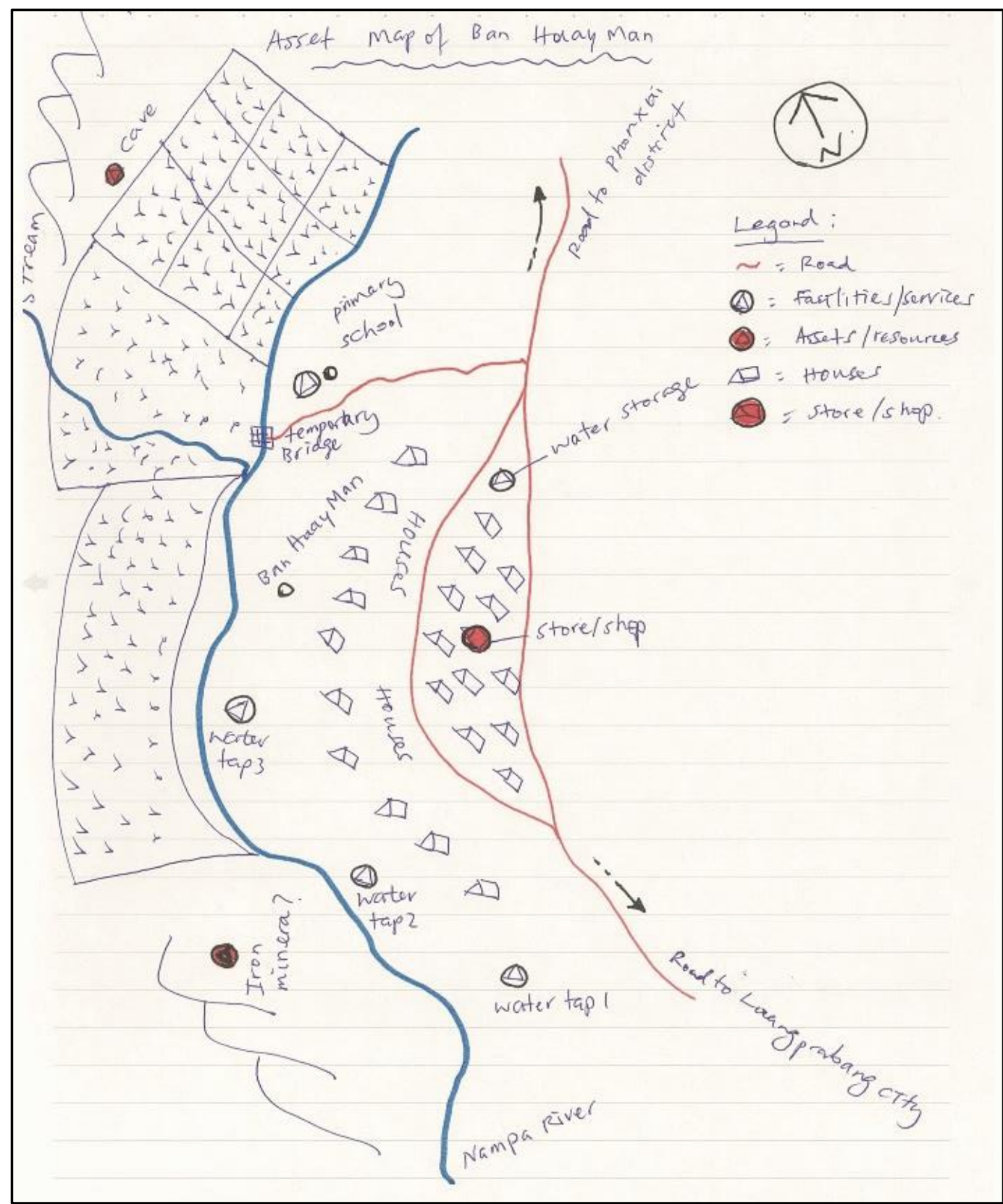

Source: Transect walks, 1/7/2016. 
Fig. 3.6 Community asset map of Ban Meuang Ngoy

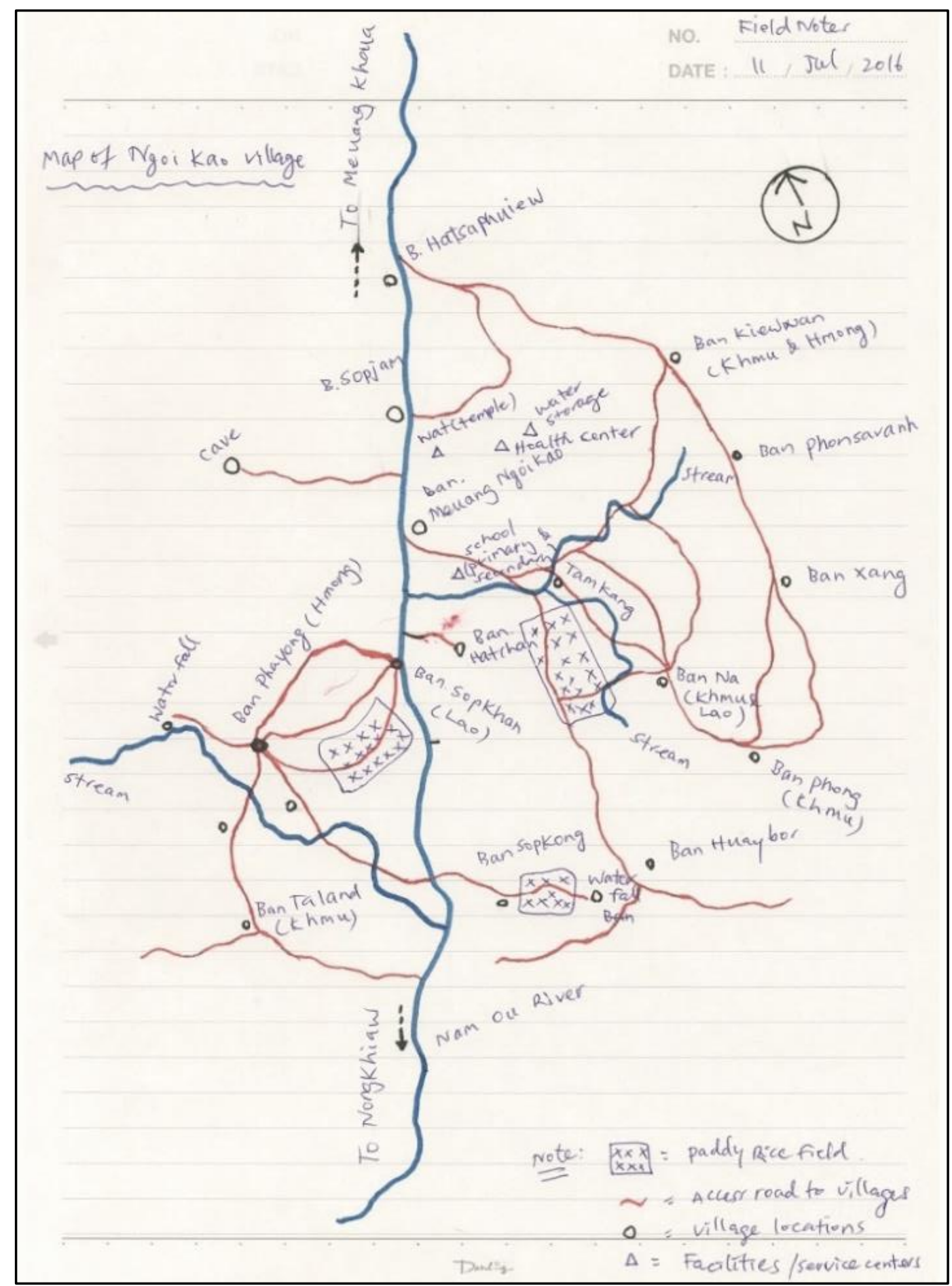

Source: Transect walks and consolidate with data from local tour agency (11/7/2016). 


\subsection{Data preparation, analysis, and interpretation}

There is no singular format when it comes to the analysis and interpretation of qualitative and ethnographic data (Hammersley \& Atkinson, 2007). One way of doing this is to start from making sense of the data collected, and then incorporate them into the theory, or form an emergent theory, if possible. This approach is known as inductive data analysis and reasoning. Another way is to start from a welldefined theory in respect of a specific case study in order to test or prove the existing theory, referred to as a deductive data analysis and reasoning approach (Hammersley \& Atkinson, 2007). Guided by a sustainable livelihood framework that takes into account the local people's perspective, I used an inductive approach to analysis in this research, putting the voices of local people upfront as opposed to the voice of the policy-makers. Following the advice of Crang and Cook (2007); Creswell (2014); Pole and Morrison (2003), I prepared and analysed the collected data in six steps as shown in Fig. 3.7 below.

Fig. 3.7 Data analysis process

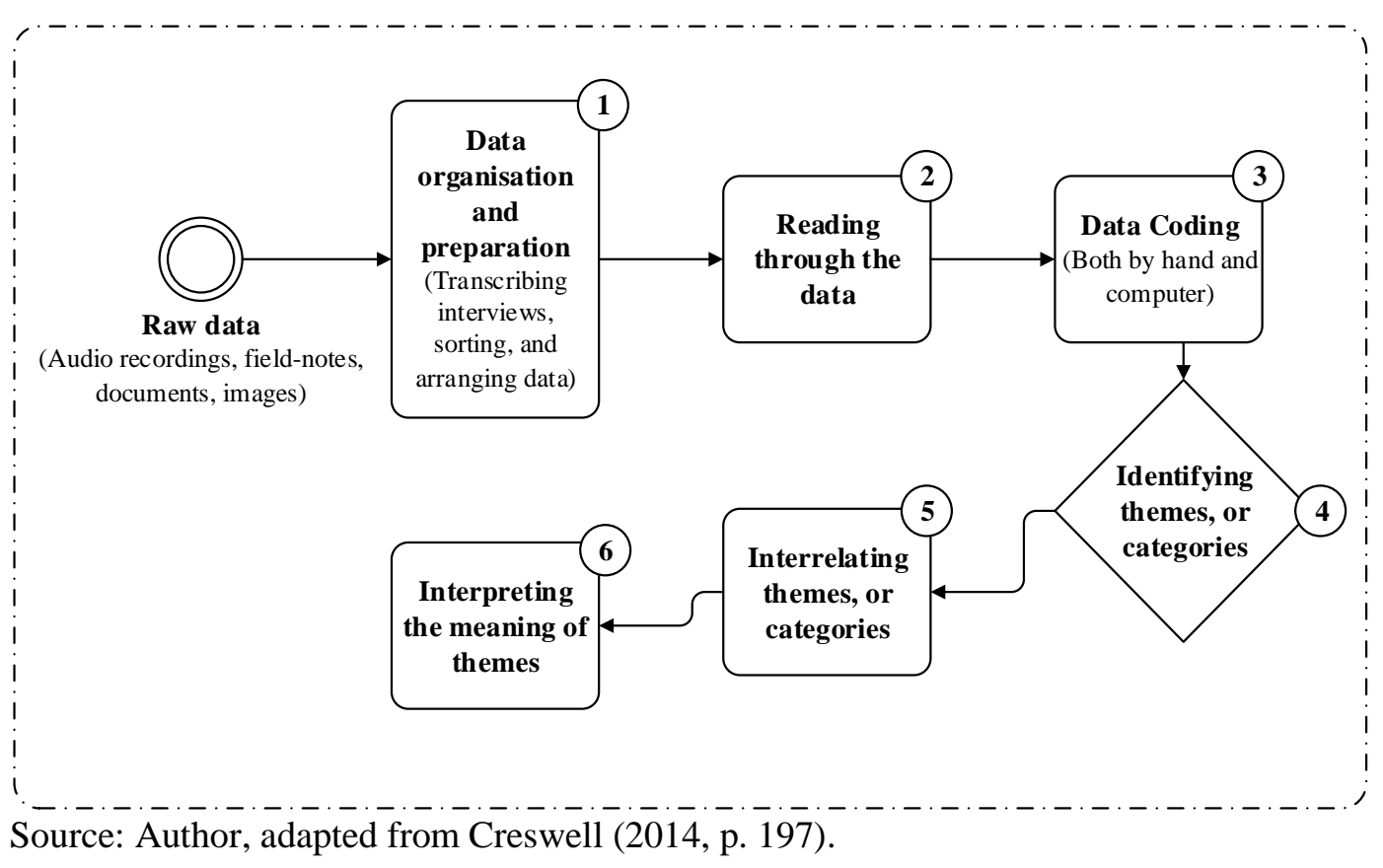

I began with organizing and preparing the data, then read through the corpus of data and generated the concepts, as well as looking for the features and patterns of data. After that, I coded the features using a computer programme (QSR NVivo 10). Data coding and identifying themes were done in parallel, with themes categorised based on the research questions (Crang \& Cook, 2007; Hammersley \& 
Atkinson, 2007). All these themes were then related to each other, before I interpreted them and integrated them into the findings of this research. When relating themes, I compared and contrasted themes with one another, as well as picking up the outstanding and interesting features of each (Hammersley \& Atkinson, 2007). This exercise entailed a careful and creative critical-thinking process (Crang \& Cook, 2007). Key themes identified in my analysis process are shown in Table 3.2 below. The themes were organised to meet to the overall objectives of the research.

Table 3.2 Identified themes for data analysis

\begin{tabular}{lcl}
\hline Key themes & Sub-themes \\
\hline Livelihoods & $\checkmark$ Characteristics of locations and cultures \\
& $\checkmark$ The availability of local resources \\
& $\checkmark$ Civelihood activities and strategies \\
& $\checkmark$ & Perceptions and aspirations of youth \\
& $\checkmark$ & Influencing factors on perceptions and aspirations \\
Perceptions and & $\checkmark$ & Education decision-making and career choices \\
aspirations & $\checkmark$ & Means for achieving aspirations \\
& $\checkmark$ & The role of school in shaping young people's \\
The role of school & & perceptions and aspirations \\
& $\checkmark$ & Relevance of courses to livelihoods and labour market \\
& & Alternatives to help young people achieve aspirations \\
Strategies and & $\checkmark$ & Purposes of education \\
policy interventions & $\checkmark$ & Vocational education systems \\
& $\checkmark$ & Strategies and policy interventions \\
& $\checkmark$ & Options for vocational education development \\
\hline
\end{tabular}

Source: Author (2017).

The final step of the data analysis process was the interpretation. My interpretation in this research put much emphasis on what was actually happening at the ground level. The interpretation was influenced by the analytical framework and epistemology used in this research. This analysis process, however, was not a straightforward progression through steps (1) to (6). Rather it was a back-and-forth process. 


\subsection{Ethical considerations}

Ethnographic research requires much attention be given to the privacy, confidentiality, and scarcity of the participants, as well as their rights and protections (Gobo, 2008). These factors have been carefully considered throughout the whole process of this research, from entering the field to the interpretation of participants' language and the use of data.

\subsubsection{Entering the field}

After receiving approval from the Human Ethics Committees of the Victoria University of Wellington (VUW-HEC) (Appendix 4) and a support letter from my supervisor (Appendix 5), the journey of the fieldwork officially begun. As I had to work with students, colleges and communities, permission letters from concerned government organisations were prepared and submitted (Appendices 6.1 and 7.1). Approval was made (Appendices 6.2 and 7.2), then the actual fieldwork started.

The official letters of notice granted were two sides of the same coin - they were very meaningful and useful, but also harmful to data collection. On the positive side, the letters stipulated requirements for the participants to collaborate, coordinate, and contribute to the research. In most cases, this had helped me get the consent form signed, and I received great contributions from the participants. On the negative side, the letters, especially when meeting with communities, were perceived as a hierarchical order from the higher government organisations. As a result, some of the participants felt hesitant to sign the consent form. For example, I was asked: "What will this form be used for?" In such situations, more clarification and explanation about the research project did help, but tensions still occurred. The interviews were not continued until a friendly environment was established and the participants seemed to be comfortable. Conducting ethnographic research in such a multi-cultural context was challenging, albeit nationality and similar cultures were shared between participants and researcher. This may be part of what Gobo (2008, p. 135) notes as an "ethical dilemma" of ethnography.

Recruiting participants in the fieldwork strictly followed the VUW-HEC guidelines. In every case, the consent form was signed before conducting the interviews or focus group. In one case, where the participant could not read and 
write, verbal consent was made. I was allowed to audio record all participants, and their real names and addresses were written in the consent forms. These audio and consent forms were then kept confidentially and safely_often, they were carried with me, or locked in a safe place at home. Participants and I also agreed that our discussions were to be kept between us - not to be shared with others. I avoided taking participants' photos, except for the focus group and transect walks. Photos used in this research were all acknowledged by the participants.

Despite the challenges explained above, good relationships, trust, respect and loyalty were developed while I was in the field (Crang \& Cook, 2007; Gilbert, 2006; Gobo, 2008). For example, after the interviews, we exchanged contact details for future professional networks, as well as to maintain our personal relationships. Participants have shown their great interest in the research, especially among educators, development workers and government officials. Some expected me to present the research findings after my graduation. Thus, I continuously received great support from a number of the participants, even after arriving on the campus. They provided some additional information when requested.

\subsubsection{Leaving the field}

Entering the field was easier than leaving it. Anxiety and uncertainty about the sufficiency of information occurred (see also Snow, 1980). To ensure information sufficiency, I followed Denzin's (cited in Snow, 1980, p. 101) advice that the fieldworker "must be prepared to leave the field at the proper time and must have a theoretical grasp of the data so that the exit time is easily discernible."

Before leaving the community, I had a chance to meet each participant to wrap up what we had discussed and to say goodbye to them. Summary notes were prepared and double-checked with participants for clarification. For those whom I could not meet in person, I made phone calls.

With students, I summed up the interviews briefly right after the activity was conducted. The reason was because there was less chance to meet them again as they were returning to their homes after finishing their exams. In the school, I had the chance to meet educators and brief them about what had been discussed with students. This effort was made because I had asked for their assistance and permission to work with students. 
With development workers and government officials, I had the chance to make phone calls. Received soft files and hard copies from them were kept in a safe place. For instance, information was saved on a flash drive and a personal computer, with passwords set and changed frequently. All these steps were to ensure the protection of participants' identities and to prevent information disclosure without permission (Gilbert, 2006; Snow, 1980).

\subsubsection{Interpreting the meanings and use of language}

Indigenous (Kmhmu) and Lao languages were used for interviews and the focus group. Translation from indigenous language to Lao and then to English was made by the author of this research. Much effort has been made to preserve the original meanings of the language. This is to ensure the validity of the information, as well as to show respect to the participants' views and expressions. Any errors of translation and interpretation of the original languages into English as used in this research are to be borne by the author.

\subsection{Positionality}

The concept of positionality is prominent in the field of social research. It is a means to unpack the reality of the people, or object being researched, thus creating the body of knowledge (Chacko, 2004; Rose, 1997). Positionality is conceptualised in different ways by different theories. In feminist theory, positionality refers to the race, gender, sexuality, religion, and social status of the researcher and the participants. It is formed under the basis of a combination between facets of the researcher and aspects of social identity or participants (Henry, Higate, \& Sanghera, 2009). In anthropological research, positionality is associated with the cultural identity of the researcher and that of the participants (Robertson, 2002). In the development research context, positionality means the perspective, orientation, and situatedness of the researcher and participants (Henry et al., 2009).

In this research, much attention has been given to aspects of positionality, as multiple axes of difference, inequality, and geopolitics exist. This is because these attributes can influence how the research was processed and its outcomes were produced (Chacko, 2004; Sultana, 2007). In two villages I visited, there are three

different types of ethnic groups-Kmhmu, Lao, and Hmong. Although I am 
$\mathrm{Kmhmu}$, my culture and traditions differ somewhat to those of the participants who are also Kmhmu, and completely differ from those who are Lao and Hmong. With this cultural difference, I, of course, was not perceived as an 'insider' (Mullings, 1999). An example was that, when I spoke Kmhmu during the introduction of the interviews, some participants in one of the visited villages commented that the dialect I spoke was not similar to theirs. Also, when arriving in the village for the first time and having my facilitator (a local government official) introduce me and my plan to work with them, I was in a position of being completely an outsider.

My positionality, however, changed in accordance to my gender and level of education. As a researcher and a student from overseas doing fieldwork in his own country, I was perceived as a well-educated person in the eye of community members. I was often asked, why did I choose their communities? Why did I need to travel from New Zealand (an advanced country, from their view) to such small rural villages (or backward villages, as they are often perceived)? These questions opened the floor for me to talk about myself, explaining my intentions for doing the research, and my curiosity to seek solutions for improving rural people's lives. It was a time for me to feel a deep connection to the communities. It was then that I felt I was an insider, with/in them, and that they were also with me.

When interviewing development workers, I was perceived as their colleague. This is because we shared similar backgrounds; I used to work for development agencies, and one of the participants was even my ex-colleague. 'When I was sitting in the backyard of the World Bank's office, drinking coffee while conducting interviews, I felt I was perceived as a complete insider, allowing the interviews themselves to proceed as friendly and open discussions.'

When meeting and interviewing a high-ranking government official (Deputy Director), I was threatened by his power (by which I mean the power of the institution, as well as his level of education and areas of expertise), presumably, without him knowing it. In such situations, I was very conscious about what questions should and should not be asked. Based on my knowledge and experience of Lao's hierarchical culture, for young people to ask questions of their seniors is something to be very mindful of and careful about. However, by the end, I managed to ask almost all the questions I wanted. He ended up asking me a question of his own, about what I wanted to be, and what I would do after my graduation. "What about being a lecturer at the National University of Laos?" he suggested. Only then 
did I feel comfortable, and that I was perceived as an insider. And yet, the last question has kept me thinking until now, why a lecturer?

These dynamics of personality might affect the degree to which information was shared by the participants, as well as the way in which I interpreted the information for my analysis in this research (Mullings, 1999). To further explain this, reflexivity is therefore needed.

\subsection{Reflexivity}

Reflexivity refers to the critical reflection of individuals in the research process, from research design to data collection and interpretation (Sultana, 2007). It is a process whereby individuals respond to an immediate context and make choices for further direction. Reflective practice is "the art" by which the researcher negotiates their relationship to their research, by acknowledging the influence of their own "position, assumptions, and worldview on [his/her] understandings and actions." (Pettit, 2006, p. 76). The process allows the researcher to understand how knowledge is created and how this knowledge relates to power.

In this research, reflexivity was used as a tool to understand how knowledge is acquired, organized, and interpreted (Pillow, 2003). Reflexivity helped me to realise that the body of knowledge is not just the facts, but involves the abstract, and exists as a continuum. Through the writing of this research, I have realised that knowledge is created depending on how I structure and interpret the information. It also is socially, culturally and historically created by people (participants) from different places, cultures, and education backgrounds. This observation is also consistent with what has been explained by social constructivism. Moreover, reflexivity has helped me to validate the accuracy of the information for this research. It was used as a tool for recognition of myself and participants, as well as judgement of what is believed to be the truth (Pillow, 2003). It can be firmly stated that my positionality, assumptions, experiences, education background and worldview all influence how the data is used, analysed and interpreted in this research. 


\subsection{Summary}

This chapter has explained the research methodology used in this research. It has clarified how the research was carried out, including the participants interviewed, research locations, and data analysis. Other considerations such as my positionality, the validity of the information, and human ethics have also been discussed. Before presenting the results of this research based on the methodology explained in this chapter, the next chapter firstly provides the overall picture of Laos so as to have a sense of the research context. 


\section{Chapter 4 \\ The social, economic and political contexts of Laos}

\subsection{Introduction}

This chapter provides the geographical, political, socio-economic and educational contexts of Laos. This contextual information is essential for my analysis and discussion in the subsequent chapters, as well as fundamental to understanding how different elements link to and influence each other. As such, the chapter provides insights into what supports and impedes development in Laos, especially within the education and training context.

The chapter is divided into two parts. Part one (sections 4.2 and 4.3) provides the geographical, demographical and cultural contexts of the country, as well as overviews of the political system and socio-economic development. Section 4.3 focuses on the economic reform strategy and its key elements pertaining to rural livelihoods. Part two (sections 4.4, 4.5 and 4.6) discusses specifically TVET development by outlining key government and donors' development plans, strategies, and funding that supports two study colleges in Luang Prabang province.

\subsection{Geography, people and culture}

Laos is the only land-locked country in Southeast Asia (UN-OHRLLS, 2016). With a territory of nearly 240,000 square $\mathrm{km}$, the country borders China to the north, Thailand to the west, Myanmar to the north-west, Viet Nam to the east, and Cambodia to the south (Lao Statistics Bureau, 2014). As the country has been handicapped by territorial access to the sea, it faces the double challenge of development and of limited access to international markets (UN-OHRLLS, 2016; World Bank, 1996, 2005b).

Despite the land-lock challenge, much of the country's terrain is rugged and mountainous (Lao Statistics Bureau, 2016). Large mountainous areas are in the 
northern region (Fig. 4.1). These 'hardly-accessible' areas have become barriers to development, making people remain poor as they cannot fully access social services provided by the government, such as education and healthcare (Fujita, 2006; MPI \& UNDP, 2009; World Bank, 1979). The government has attempted to address the challenge by improving infrastructure such as roads to many villages in rural areas. Yet, the most recent figures show that less than 60 percent of rural residents have access to roads (Lao Statistics Bureau, 2016).

Fig. 4.1 Laos: The land-locked country and identified mountainous areas

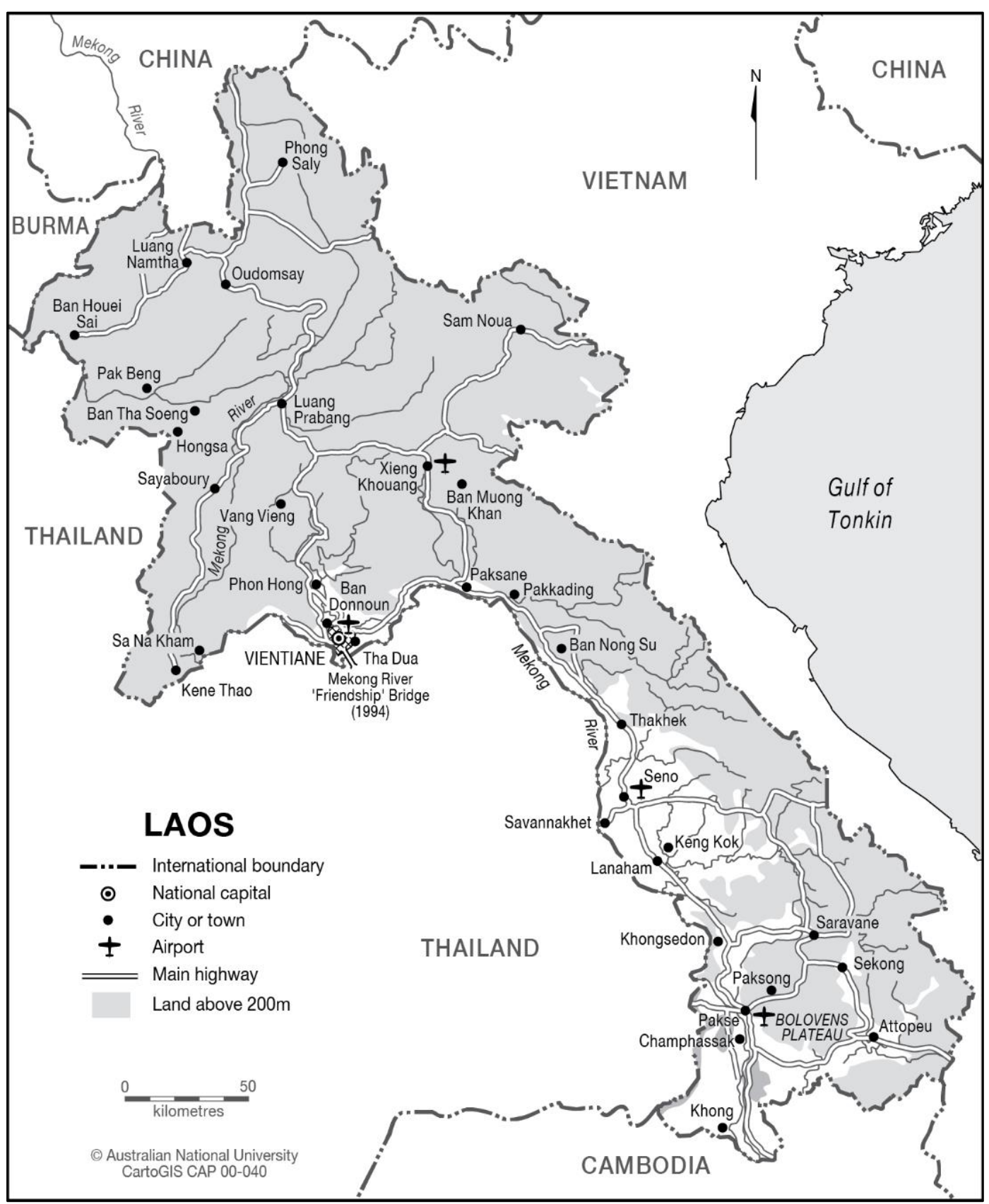

Source: Australian National University (n.d.). 
Laos is characterised as a small, sparsely populated country (World Bank, 2005b). Geographically, the country is divided into three different regions: the north, the centre, and the south (Epprecht, Minot, Dewina, Messerli, \& Heinimann, 2008). The north consists of seven provinces, including Luang Prabang. The centre consists of six provinces ${ }^{3}$ and Vientiane, the capital. And the south consists of four provinces (Lao Statistics Bureau, 2016). The country's population is, however, unevenly distributed across its territories (Lao Statistics Bureau, 2016) (Fig. 4.2). The proportion of population residing in rural, upland areas is larger than that of urban areas. As of 2015, around 67 percent of the population were rural residents, a decline of only six percent over the previous decade (the figure was 73 percent in 2005) (Lao Statistics Bureau, 2016). The country's geographical characteristics suggest that rural development should be the priority if the coverage of education and health care services are to be increased, and poverty is to be reduced.

Fig. 4.2 Lao population (2015), by region and province

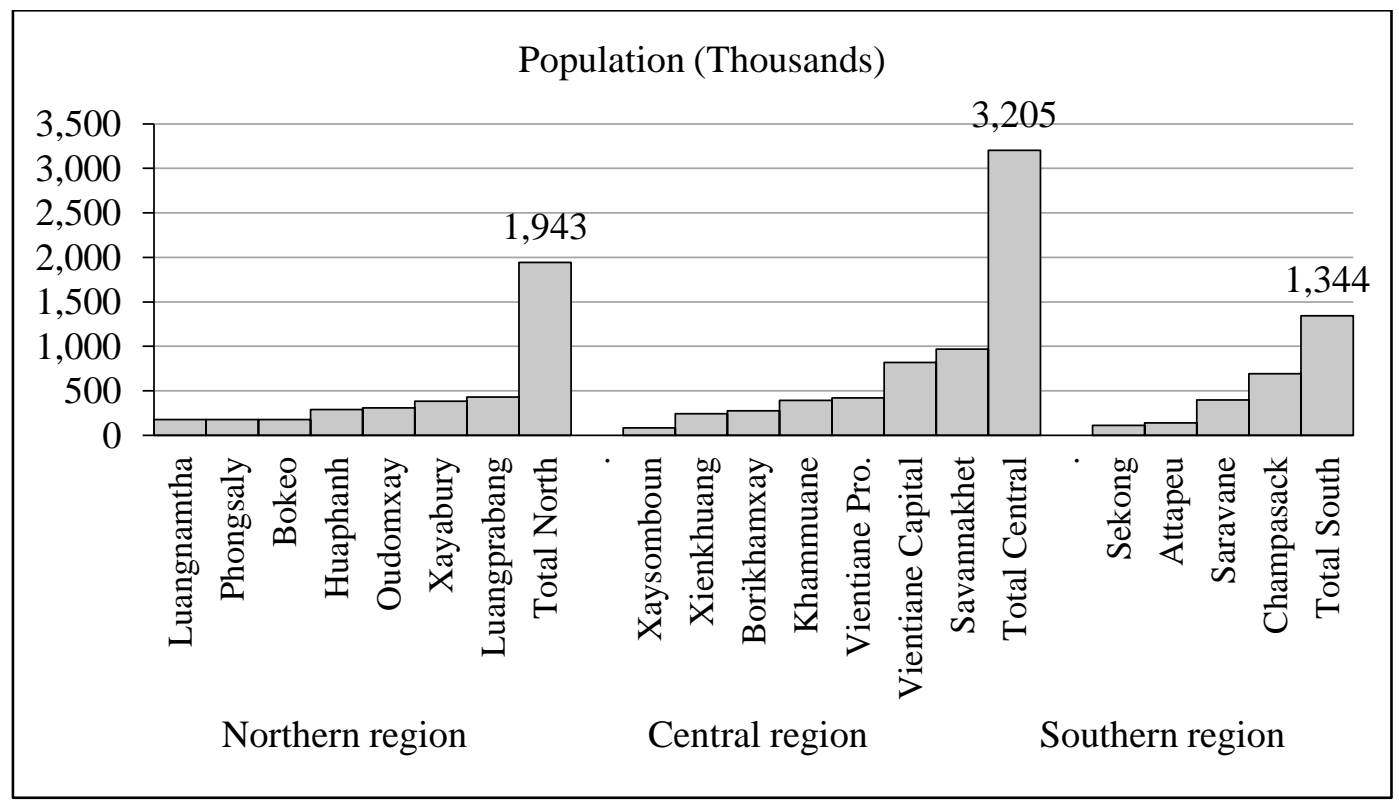

Source: Author's illustration using data from Lao Statistics Bureau (2016, p. 29).

Laos has the youngest population compared to other countries in the region (Lao Statistics Bureau, 2016). In 2015, half of the pollution was below 24 years old, and the population of working age (15-64) accounted for nearly 64 percent of the

\footnotetext{
${ }^{3}$ Xaysomboun province was previously designated as a special administrative zone. It officially became a province on December 13, 2013, according to National Assembly Decree No.012/NA, with two additional districts (Home and Longsane), which used to be part of Vientiane Province (Lao Statistics Bureau, 2016).
} 
total population (Lao Statistics Bureau, 2016). A study (UCW, 2014) observes that whether this youth bulge is "an economic boon or a missed opportunity will depend on how young people's aspiration can be met within the country with appropriate policy responses." (p., 4). In theory, as reviewed in chapter 2, TVET can play an important role in promoting youth education and development in Laos which will be discussed throughout the research.

Laos has diverse ethnicities and multiple cultures, with many speaking their own languages (King \& Walle, 2012). According to Pholsena (2002), there are 49 sub-ethnic groups, classified into four ethno-linguistic categories: Lao-Tai, MonKhmer, Hmong-Iu Mien, and Chinese-Tibetan (Table 4.1). Mon-Khmer ethnic groups, specifically the Kmhmu, are believed to be the indigenous people of Laos, with the first wave of migration to the country from Lao-Tai peoples, followed by Hmong-Iu Mien and Chinese-Tibetan respectively (Ireson \& Ireson, 1991; StuartFox, 1986, 1997, 2008).

Table 4.1 The ethno-linguistic families and categories

\begin{tabular}{|c|c|c|}
\hline $\begin{array}{l}\text { Ethno-linguistic } \\
\text { families }\end{array}$ & $\begin{array}{l}\text { Ethno-linguistic } \\
\text { categories }\end{array}$ & Ethnic groups \\
\hline $\begin{array}{l}\text { Lao-Tai } \\
\text { (Tai-Kadai) }\end{array}$ & $\begin{array}{ll}\text { 1. } & \text { Lao } \\
\text { 2. } & \text { Tai-Thay }\end{array}$ & $\begin{array}{l}\text { Lao } \\
\text { Phou Thay, Tai, Nyouan, Lue, Yang, Sek, } \\
\text { Tai Neua, Lao }\end{array}$ \\
\hline $\begin{array}{l}\text { Mon-Khmer } \\
\text { (Austroasiatic) }\end{array}$ & $\begin{array}{l}\text { 4. Palaungic } \\
\text { 5. Katuic } \\
\text { 6. Bahnaric- } \\
\text { Khmer } \\
\text { 7. Vietic }\end{array}$ & $\begin{array}{l}\text { Khmou, Pray, Ksing Moul (Sing Moun), } \\
\text { Phong, Thène, Oe Dou, Kri (in Xayabury } \\
\text { province) } \\
\text { Lamet, Bit, Sam Tao } \\
\text { Katang, Makong, Tri, Ta Oy, Katu, Kriang, } \\
\text { Souay, Pacoh } \\
\text { Jrou (Laven), Triang, Yè', Brao, Halak, Oy, } \\
\text { Cheng, Sadang, Nya, Heun, Lavi, Khmer } \\
\text { Toum, Ngouan, Meuang, Kri (except in } \\
\text { Xayabury); Phong (except Phong assigned to } \\
\text { Khmuic) }\end{array}$ \\
\hline Sino-Tibetan & $\begin{array}{l}\text { 8. Tibeto- } \\
\text { Burman }\end{array}$ & Akha, Singsily, Lahu, Sila, Hanyi, Lolo, Ho \\
\hline Hmong-Mien & $\begin{array}{l}\text { 9. Hmong } \\
\text { 10. Mien }\end{array}$ & $\begin{array}{l}\text { Hmong } \\
\text { Lu Mien }\end{array}$ \\
\hline
\end{tabular}

Source: Adjusted from Messerli et al. (2008, p. 81).

The distribution of ethnic groups is diverse and typical (Fig. 4.3). Any place where people choose to live and make a living seems to become deeply connected to their 
culture. While the vast population of Mon-Khmer, the Kmhmu, reside in the north (Fig. 4.3-C), Hmong-Iu Mien have spread out from the north to the centre (Fig. 4.3D). The Lao-Tai population stretches throughout the country, but resides mainly in lowland areas (Fig. 4.3-A, B). Simana and Preisig (2006) explain that the Kmhmu usually reside in the upland areas as their main livelihood activities depend on upland farming systems. Sengxua (2006) states that the Hmong ethnic group's livelihood system is linked to agriculture, especially raising livestock in highland areas. Hatsadong, Douangsila, and Gibson (2006), on the other hand, report that the Lao-Tai ethnic group prefers residing along the low-land areas, mainly along the river banks, as their livelihood activities are related to wetland farming and trade. Diverse ethnic groups and multiple cultures suggest that development policy in Laos must be holistic and inclusive so that it serves the diverse interests and aspirations of local people. 
Fig. 4.3 Demographical characteristics by ethno-linguistic categories (A, B, C and D)

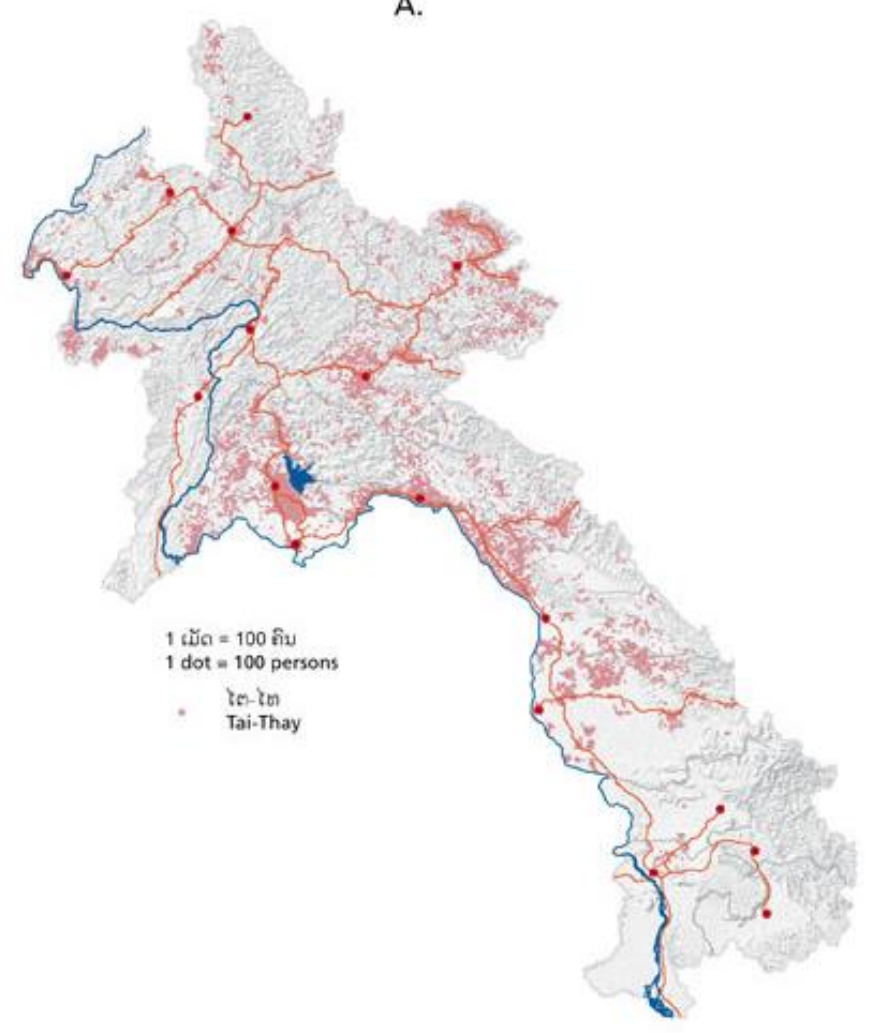

B.

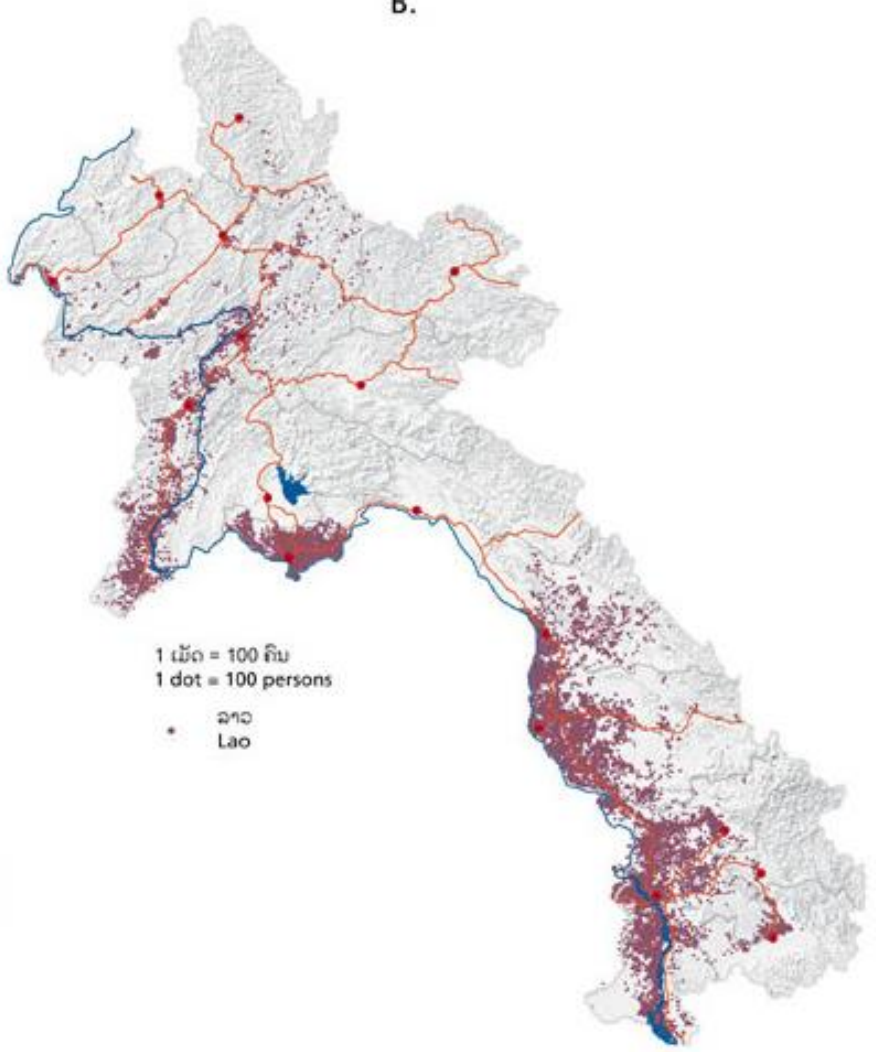



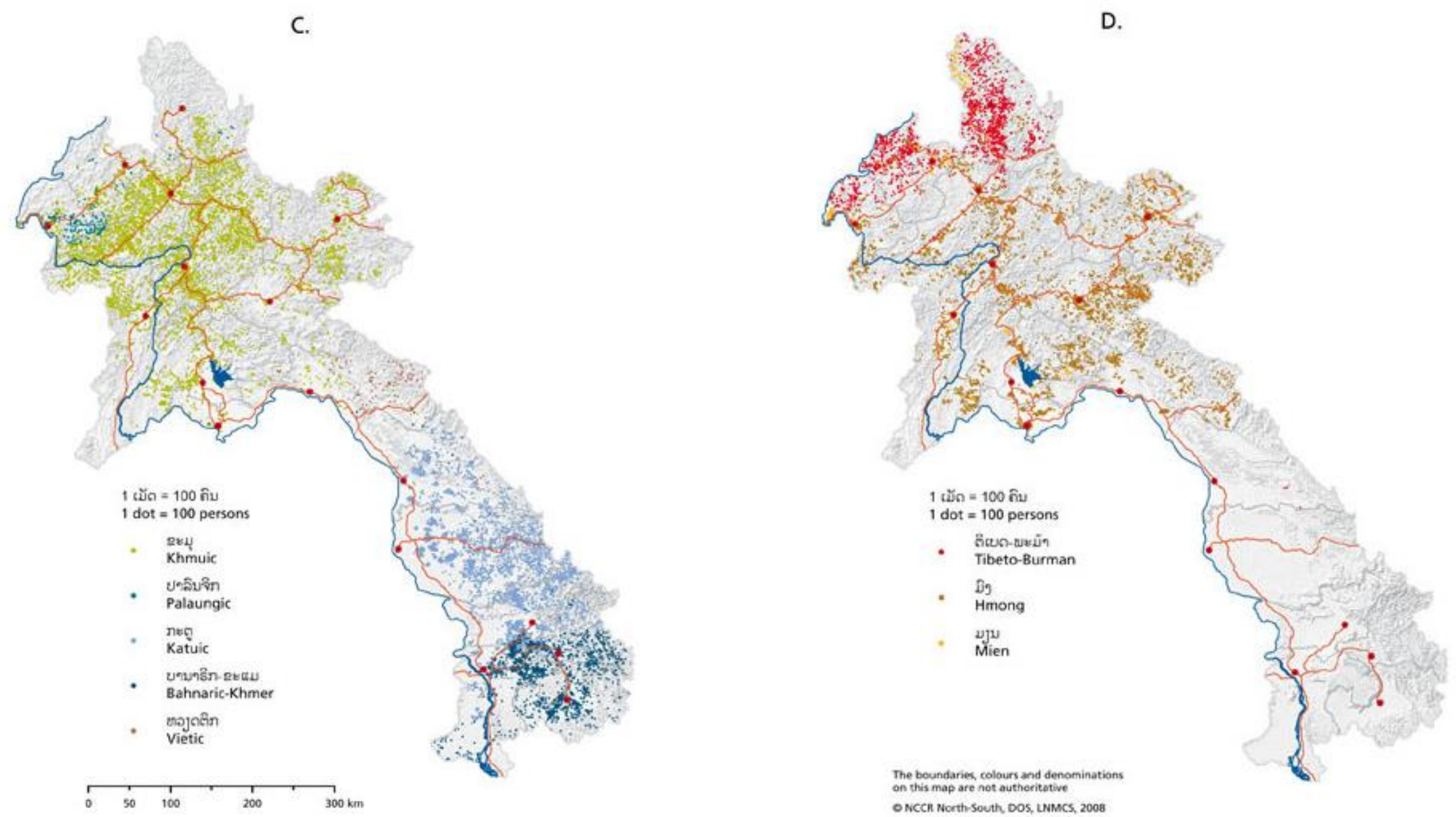

Note: $\mathrm{A} \& \mathrm{~B}=$ Lao-Tai; $\mathrm{C}=$ Mon-Khmer; $\mathrm{D}=$ Hmong-Iu Mien and Chinese-Tibetan

Source: Lao PDR (2005) 
Several studies reveal higher poverty among ethnic minorities, and residents living in the northern region, rural and upland areas, or rural villages without, or seasonal, road access (Coulombe et al., 2016; Messerli et al., 2008; MPI \& UNDP, 2009; Rigg, 2016) (Table 4.2). Coulombe et al. (2016) mapped out where the poor in Laos reside, and revealed that poverty varies widely across regions, provinces, districts, and villages. The authors also commented that the diversity of ethnic groups and the high level of heterogeneity in poverty suggest that the country needs a holistic development planning approach.

Table 4.2 Incidence of poverty by geography and ethnic groups, 2002-2003

\begin{tabular}{lll}
\hline & $\begin{array}{l}\text { \% of national } \\
\text { population }\end{array}$ & $\begin{array}{l}\text { Incidence of poverty } \\
\text { (headcount, \%) }\end{array}$ \\
\hline National poverty rate & - & 33 \\
Geographical area 1 & - & \\
Vientiane capital & - & 15.7 \\
Northern region & - & 34.5 \\
Central region & - & 27.9 \\
Southern region & & 33.5 \\
Geographical area 2 & 23 & \\
Urban & 77 & 19.7 \\
Rural & & 37.6 \\
Geographical area 3 & 57.5 & \\
Lowland & 17.5 & 28.2 \\
Midland & 25.0 & 36.5 \\
Upland & & 43.9 \\
Geographical area 4 & - & \\
No rural road access & - & 21.7 \\
Seasonal rural road access & - & 27.9 \\
All-weather rural road access & & 9.7 \\
Ethnic groups & 66.6 & 25.0 \\
Lao-Thai & 20.6 & 54.3 \\
Mon-Khmer & 8.4 & 40.3 \\
Hmong-lu Mien & 3.3 & 45.8 \\
Chinese-Tibetan & 1.1 & 48.4 \\
Others &
\end{tabular}

Source: Extracted from Rigg (2016, p. 210).

\subsection{Political system and socio-economic development}

This section provides an overall picture of the political system and socio-economic development in Laos. It also provides the background of the country's economic policy reform and its key elements which will be discussed in the next chapter, in particular how rural livelihood activities have been influenced by these elements. 


\subsubsection{Political system}

Since the declaration of the country's independence in December 1975, the Lao People's Revolutionary Party (LPRP), formed in 1930 and established in 1955, has been in power, ruling the country to the present day (Freeman, 2001). Following Marxist-Leninist ideological orthodoxy, and influenced by the former Soviet Union model, Laos has chosen to remain a single-ruling party system, alongside its neighbouring countries, such as the People's Republic of China, and the Socialist Republic of Vietnam (St. John, 1995; Stuart-Fox, 2007). According to the constitution, articles 1 and 2, Laos, as a country, is "a People's Democratic State," "all powers are of the people, by the people and for the interests of the multi-ethnic people of all strata in society with the workers, farmers and intellectuals as key components" (Lao PDR, 1991). It is quite interesting that although the country follows the socialist regime, it defines itself as a "democratic state", which differs from the case of China and Vietnam. This implies that the country embraces democracy, as, according to its own constitutional terminology, democracy means the government of the people, by the people, and for the people (Lao PDR, 1991).

The LPRP (or, in Lao, Phak Pasason Patavat Lao) is tasked to take the “leading nucleus" role of the country's political system (Freeman, 2001, p. 141). However, that task was not clearly defined until the constitution was adopted in 1991, which means that the Party governed the country without a formal constitution for fifteen years, from 1975 to 1990 (Slater \& Keoka, 2012). The 'leading nucleus' role means that the Party takes a lead in managing all the main governance institutions of the country, from central to provincial, district, KumBan, and village levels (Slater \& Keoka, 2012).

Recently, Stuart-Fox (2007, p. 178) observed that "there is a younger generation of technocrats, whose higher education was not in Marxism-Leninism in Moscow and Hanoi, but in technically useful subjects in good Western universities,.. and they understand far better than the current political leadership what benefits reforms can bring." What Stuart-Fox meant by 'reform' is not quite clear. According to Slater and Keoka (2012), such reform may refer to the promotion of justice, decentralisation, equitable service delivery and participation. In their study on the governance sector in Laos, Slater and Keoka (2012) reveal that there are some changes occurring in the political system in Laos. They have found that "with increasing education and knowledge levels among senior members [of 
the Party/Lao government], and greater interaction with donor partners, a gradual shift has occurred towards more coherent and strategic policy development: the Party now recognises the importance of governance reform and international integration" (Slater \& Keoka, 2012, p. 14). Slater and Keoka (2012, p. 8) further assert that the evolution of the system of governance since the establishment of the Lao PDR in 1975 has been a "slow, but steady" process.

\subsubsection{Economic reform and key elements reflecting rural livelihoods}

As a single-party governance system, the national socio-economic development policy is defined and directed by the Party (Stuart-Fox, 2007). Such political direction does not only influence change at the national level, but also at the grassroots level. It is, therefore, useful to provide a historical account of economic reform in Laos and highlight some key elements that reflect the livelihoods of the local people in the country.

The Lao economic reform can be traced back to the time the country received independence in 1975. From 1975 to 1978, with the influence of the socialist political regime, Laos chose to follow the centrally-planned economic model. Not long after, in 1979, a mixed socialist and capitalist economic model was introduced (St. John, 1997). Arndt (1992, p. 200) asserted that the introduction of these different economic policy models during the first decade (1975-1985) constituted "a time of trial and error."

The economic reform, known as the New Economic Mechanism (NEM), in Laos was not successful until 1986 (Gunn, 1988). Arndt (1992, p. 199) coined that that year was "the right turn" of economic policy directions. Undoubtedly, there was great tension, negotiation and heated debate between the 'pro-socialist' and 'pro-capitalist' groups over this change (Gunn, 1988). However, the proposed economic reform was finally approved as "the government accepted that socialism cannot be achieved by 'bypassing the capitalist phase,' and instead has embraced policies that that will open the economy further to trade and private capital" (Worner, 1989, p. 196). The NEM has then been implemented as a mainstream development in Laos until today (Rigg, 2005).

The reader is reminded that chapter 5 will discuss the influence of NEM on how rural livelihoods are organised. Thus, I will present some key elements of NEM 
in this section so as to have a clearer understanding about its implications on livelihoods.

In his book, Living with transition in Laos: Market integration in Southeast Asia, Rigg (2005) explains that the NEM entails:

1 A move to a market determination of prices and resource allocation.

2 A shift from central planning to guidance planning.

3 An elimination of subsidies and the introduction of monetary controls.

4 An alignment of the domestic currency with the market rate.

5 A decentralisation of control to industries and lower levels of government.

6 The encouragement of the private sector.

7 The encouragement of foreign investment.

(Rigg, 2005, pp. 19-20).

The above elements mainly reflect the economic structural change at the macro level. Lilao (2005) further elaborates that the main objectives of introduction and implementation of the NEM are to encourage economic growth and improve the living standards and well-being of all Lao people, both in urban and rural areas, regardless of gender and ethnicity. This will be done, according to Rigg (1997, p. 19), by reorienting "a subsistence system to market demands." The government's interventions attached to the policy reform, as Rigg (2006, pp. 126-127) explains, were the introduction of the Land and Forest Allocation Programme (LFAP) and the Focal Site Strategy in the 1990s, aimed at "eliminating shifting cultivation and stabilising agriculture... and creating 'growth zones' or 'development poles' that become 'centres of change and learning' where the transition from subsistence to market is enhanced." Moreover, expanding roads to rural areas in the hope of encouraging more people to access social services, and to purchase and exchange agricultural products, is also a major focus of the NEM. Rigg (2005, 2009, 2016) argues that the introduction of NEM has created poverty, which he often refers to as 'new poverty.' It has also enlarged the inequality gaps between rural and urban populations. I will discuss this more in chapter 5 where the livelihoods of people in two rural villages are analysed.

\subsubsection{Development priorities and performance indicators}

Increasing economic growth, reducing poverty and strengthening human capital are key priorities for development in Laos. Menon and Warr (2013) state that, right 
after the adoption of the economic reform in the mid-1980s, the Lao government introduced wide-ranging, market-oriented economic policies and plans to improve the country's economy. Laos is naturally a resource-abundant country. Natural resources include land, forestry, minerals, and rivers that are suitable for hydropower plants. The government, with support from international development experts, has therefore chosen a 'natural resource-based' approach as a means to develop the country and encourage prosperity (Menon \& Warr, 2013; World Bank, 1979). Results show that the economic growth rate has steadily increased at 7.5 percent per annum in the past decade and a half (World Bank, 2014b). According to ADB (2017), such growth enabled the country to meet its target under the Millennium Development Goals to halve extreme poverty by 2015. ADB (2017) further states that Laos has been considered as one of the fastest-growing economies in Southeast Asia for the past decade; however, the rapid growth, derived from industrial sector activities such as hydropower and mining, does not fully trickle down to the poor, mainly because the industrial sector (mining and hydropower) has created few jobs for local people in the country. Therefore, poverty remains.

Poverty reduction has been the Lao government's number one priority area of development, especially since the early 2000s. The National Growth and Poverty Eradication Strategy (NGPES) towards 2020 was developed and published in 2004. The four poverty-focused areas are agriculture, education, health, and transportation, and were clearly outlined in the strategy (Lao PDR, 2004). For the education sector, significant attempts have been made both by the government and its development partners. In 2011 alone, for instance, around 60 percent (US\$42.5 million of a total US\$71 million) of all aid has been injected into the education sector (UCW, 2014).

While many development aspects have been achieved so far, several development challenges remain, especially in terms of job creation for rural youth (MPI \& UNDP, 2016). The World Bank (2014a, p. 17) reveals, for example, that "7 in 10 Lao workers are still mainly employed in low-productivity agricultural jobs that keep them on the farm despite lower living standards and this is particularly troubling considering that about 1 million children under the age of 10 live on farms. More than three and half million of the population [79 percent of the population] of 10 years old and over are engaged in the farm activities." A study from the Understanding Children's Work (UCW) Programme in Laos (UCW, 2014, 
p. 39) also reported that "three of every four employed youth are poor despite having a job. Levels of working poor are especially high among young persons working in agriculture. Over fourth-fifths of youth working in agriculture are poor, compared to youth working in manufacturing, services and in commerce."

The low productivity of rural youth leads to low income generation and thus many remain in a vicious cycle of poverty. With low productivity, the level of income generation is low, leading to low saving and investment and vice versa (UCW, 2014). Low productivity is mainly caused by low levels of human capital (MPI \& UNDP, 2009; UCW, 2014; World Bank, 2014a). TVET is, therefore, seen as a strategy to improve the quality of human capital and to reduce rural poverty (MAF, 2008; MOE, 2007b). The subsequent sections examine the government's plans, strategies and funding, as well as the assistance from donors in supporting TVET in Laos.

\subsection{TVET structure and performance}

\subsubsection{TVET system and administration}

Laos is at the second stage of its education reform, and education development has shifted to focusing on higher education, particularly in the TVET subsector (Hilal, Huang, \& Lanzona, 2016). A major change to have occurred is the approval of new law on TVET (Phomilay, 2012). The law defines the TVET system as comprising three different types: formal, non-formal, and integrated vocational education and training (Lao PDR, 2014). According to the law, formal vocational education is arranged on a regular basis in educational institutions. The non-formal is arranged on a short-term basis in either educational institutions, community centres, labour units, or on-the-job training (such as private firms). And the integrated vocational education and training (IVET) is a combination of the formal and non-formal education types (Lao PDR, 2014). Note that my research focuses on formal TVET.

In Laos, public TVET programmes are provided, governed and managed by several ministries. The Ministry of Education and Sports (MOES) is the main TVET provider in the country and has overall responsibility for the governance and administration of both public and private TVET institutions (Lao PDR, 2014). Its key roles include policy and legislation formulation, qualification framework creation, and inspection and evaluation of TVET activities (Noonan et al., 2013). 
Some professional education and training are provided by other ministries and private organisations based on their areas of expertise (UNESCO, 2013). Note that, in this research, I discuss only TVET provided by MOES and the Ministry of Agriculture and Forestry (MAF) as they are relevant to the case studies I conducted in Luang Prabang province.

\subsubsection{National Vocational Qualifications Framework (NVQF)}

An education qualification framework includes not only the qualification that one receives, but also the requirements that one must satisfy to be eligible for entry. It must be noted that in past decades, admission to TVET required students to hold at least a lower secondary education certificate (Lao PDR, 2000, 2007). Hence, many students, especially school leavers from remote areas, found it difficult to access TVET. The new TVET law, therefore, expands its offer and coverage by establishing the National Vocational Qualification Framework (NVQF) that provides skills at five different levels, as shown in Table 4.3. Two certificate levels (C1 and C2) were newly added in this new law (Lao PDR, 2014).

Table 4.3 National Vocational Qualification Framework (NVQF) in Lao PDR

\begin{tabular}{|c|c|c|c|}
\hline Level & Qualification & Entry requirements & $\begin{array}{l}\text { Duration of } \\
\text { training }\end{array}$ \\
\hline 1 & $\begin{array}{l}\text { Certificate } 1(\mathrm{C} 1) \\
\text { (basic qualification) }\end{array}$ & $\begin{array}{l}\text { Primary education, or } \\
\text { equivalent, and higher }\end{array}$ & 3 to 6 months \\
\hline 2 & $\begin{array}{l}\text { Certificate } 2 \text { (C2) } \\
\text { (semi-skilled } \\
\text { qualification) }\end{array}$ & $\begin{array}{l}\text { Primary education, or } \\
\text { equivalent, and higher }\end{array}$ & 0.5 to 1 year \\
\hline 3 & $\begin{array}{l}\text { Certificate } 3 \text { (C3) } \\
\text { (skilled } \\
\text { qualification) }\end{array}$ & $\begin{array}{l}\text { Lower secondary education, or } \\
\text { equivalent, and higher }\end{array}$ & 1 to 2 years \\
\hline 4 & $\begin{array}{l}\text { Diploma } \\
\text { (technician } \\
\text { qualification) }\end{array}$ & $\begin{array}{l}\text { Lower secondary education, or } \\
\text { equivalent, and higher }\end{array}$ & 1 to 3 years \\
\hline 5 & $\begin{array}{l}\text { High Diploma } \\
\text { (higher technician } \\
\text { qualification) }\end{array}$ & $\begin{array}{l}\text { Upper secondary education, or } \\
\text { equivalent, and higher }\end{array}$ & 1 to 3 years \\
\hline
\end{tabular}

Source: Author summarised based on Hilal et al. (2016); Lao PDR (2014). 
Hilal et al. (2016) note that UNESCO has supported Laos in the development and implantation of NVQF. The authors also note that there might be somewhat of an influence from this organisation in terms of how NVQF was developed. During my fieldwork, TVET experts from the Deutsche Gesellschaft für Internationale Zusammenarbeit (GIZ) reported that they supported MOES to ensure the C1 and C2 levels are implemented in accordance with the law (Interview, 1/8/2016). Hilal et al. (2016, p. 25) assert, however, that "the framework is likely to take several years to complete, and implementation remains problematic," although general guidelines exist. Additionally, the integration of the ASEAN Economic Community (AEC) in 2015 has required Laos to improve NVQF to meet the regional framework standard (Hilal et al., 2016). This adds more pressure on Laos in developing the framework such that it meets local needs as well as international requirements.

\subsubsection{TVET performance}

TVET performance has not yet been at the level to earn the government's satisfaction. Although the overall enrolment trend has increased over the past decade (Fig. 4.4), the number of TVET entrants is not sufficient to meet current socio-economic development demands. This is partly because a large proportion of students were in favour of general education as opposed to TVET (Interview with a high-ranging government official from MOES, 9/8/2016). A study conducted by the World Bank (2013, p. 103) revealed that "the lack of interest ... of the youth ... is the most important obstacle to expanding enrolment." Investment insufficiency, including aid flows into the TVET subsector, was another major reason for limited expansion (World Bank, 2013). 
Fig. 4.4 The overall students' enrolment trends in TVET in Laos

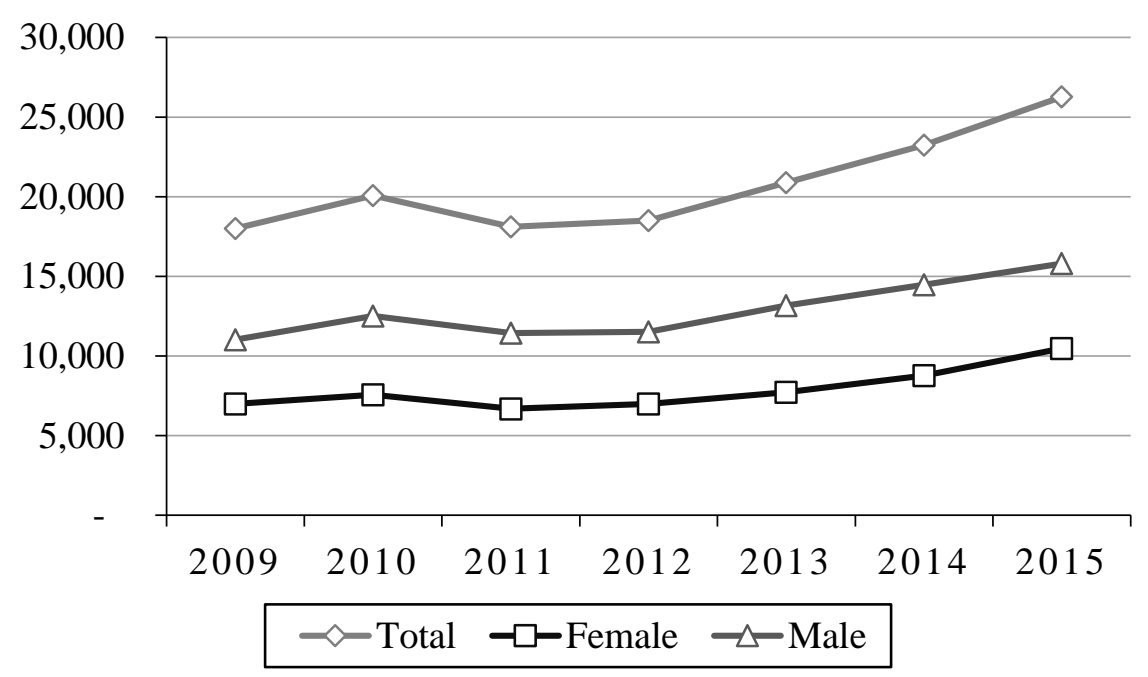

Source: Author's illustration based on raw data from MOES (2013, 2015b).

Statistically, Laos has made great progress in terms of promoting more women to higher education (Fig. 4.5). However, it cannot be said firmly that the GPI indicator calculated under this 'tertiary education' category was high. Presumably, as many people chose university education, the GPI ratio presented in Fig. 4.5 may include a large proportion of university students than students of TVET. A lack of information about GPI in TVET has become a challenge to providing an in-depth analysis on this matter at the national-data level. In section 4.6, however, I provide some aggregated information using the dataset of two colleges in Luang Prabang province where the research took place and which may help us see a clearer picture in terms of gender parity at the school-data level. 
Fig. 4.5 Gender parity index (GPI) in the education sector in Laos

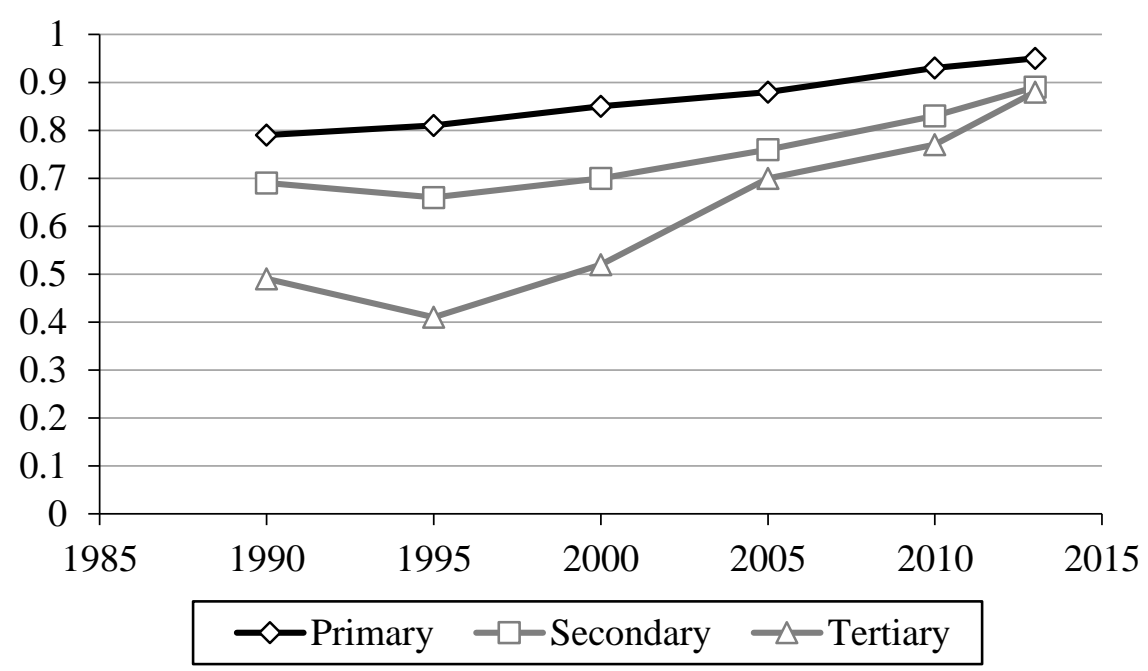

Source: Author's illustration based on online data from United Nations (2015a).

Until recently, there were twenty-three MOES-TVET institutions in the country: seven in the north, twelve in the central region, and four in the south (MOES, 2015b). As my research focuses on a particular region (the north), it is useful to present the student enrolment trend by region. Doing so will help us see where TVET has already largely expanded and where more effort is needed.

Based on the most up-to-date statistics, student enrolment in the country is slightly more than 1,000 persons per TVET institution (Table 4.4). The number, however, differs in each region. The largest numbers were achieved by TVET institutions in the central region, followed by the south, and the north respectively. Statistically, this suggests scope for more expansion of TVET exists especially in the north, and encouraging more women to TVET should be considered in respect of this.

Table 4.4 MOES-TVET institutions, enrolments and Gender Parity Index (GPI)

\begin{tabular}{|c|c|c|c|c|c|c|}
\hline \multirow{2}{*}{ Region } & \multirow{2}{*}{$\begin{array}{l}\text { Number of } \\
\text { institutions }\end{array}$} & \multirow{2}{*}{$\begin{array}{c}\text { Average size of } \\
\text { enrolment } \\
\text { (Students/TVET) }\end{array}$} & \multicolumn{3}{|c|}{ Number of students } & \multirow{2}{*}{$\begin{array}{l}\text { Gender } \\
\text { Ratio* }\end{array}$} \\
\hline & & & Total & Female & Male & \\
\hline North & 7 & 755 & 5,284 & 1,808 & 3,476 & 0.52 \\
\hline Central & 12 & 1470 & 17,634 & 7,480 & 10,154 & 0.74 \\
\hline South & 4 & 837 & 3,346 & 1,179 & 2,167 & 0.54 \\
\hline Total in country & 23 & 1142 & 26,264 & 10,467 & 15,797 & 0.60 \\
\hline \multicolumn{3}{|c|}{ GPI in tertiary level enrolment** } & & & & 0.88 \\
\hline
\end{tabular}

Note: *Calculation: Gender Ratio = female/male. This simple calculation is used for this purpose only and does not necessarily reflect the national and international calculation standard.

Source: Author's illustration based on data from MOES (2015b); Gender Parity Index (GPI)** is the data of 2013, data from United Nations (2015a) database. 
TVET enrolment trends differ by sector (Table 4.5). As the main programmes provided by MOES are related to service and industry sectors, the proportion of enrolment in these two sectors is higher than other sectors (e.g., agriculture). This is because MOES manages only one agricultural TVET institution, located in Vientiane capital (MOES, 2017). This educational trend contradicts some arguments for what is needed for the country's development as a whole; for example, I presented earlier an argument that the agricultural sector should be expanded, especially for rural youth. Chapter 7, however, provides further insights into this and discusses the role that TVET can play.

Table 4.5 MOES-TVET enrolments, by sector

\begin{tabular}{lrrrrrrr}
\hline Sector & Total & $(\%)$ & Female & \multicolumn{1}{c}{$(\%)$} & Male & \multicolumn{1}{c}{$(\%)$} & $\begin{array}{c}\text { Gender } \\
\text { Ratio }\end{array}$ \\
\hline Service & 12,046 & 45.87 & 7,904 & 75.51 & 4,142 & 26.22 & 1.91 \\
Industry & 10,558 & 40.20 & 731 & 6.98 & 9,827 & 62.21 & 0.07 \\
Agriculture & 3,660 & 13.94 & 1,832 & 17.50 & 1,828 & 11.57 & 1.00 \\
\hline All sector & 26,264 & 100.00 & 10,467 & 100.00 & 15,797 & 100.00 & 0.99 \\
\hline
\end{tabular}

Note: Percentage and gender ratios are calculated by the author. Percentage $=$ number of enrolments by sector/total enrolment of all sectors. Gender ratio $=$ female $/$ male in each sector. Also note that the number of students enrolled in teacher education programmes is counted under the service sector (the MOES's statistics treat this independently).

Source: Author based on data from MOES (2015b, p. 37).

As shown in Table 4.5, TVET enrolment trends also differ by gender. In the service sector, female student enrolment outweighed that of their male counterparts, implying that women are more interested in TVET programmes related to the service sector. Most male students, on the contrary, enrolled in industrial sectorrelated programmes. There is little difference in terms of the enrolment segment by gender in programmes related to the agricultural sector. Before providing a concluding statement about this trend, it is vital to examine the enrolment trends of TVET provided by the Ministry of Agriculture and Forestry (MAF).

MAF has the overall responsibility for improving skills in agriculture. Across the country, there are only five vocational agricultural education and training institutions, excluding an institution provided by MOES. These institutions include one in the north, two in the centre, and two in the south (MAF, 2008). As shown in 
Table $4.6^{4}$, the average size of enrolment in agricultural TVET was less than 500 persons per institution, half that of MOES-TVET. Table 4.6 also shows that male students were predominant in agricultural TVET. There was a small number of female students from the north enrolled in this sector.

Table 4.6 Number of enrolments in MAF-TVET institutions, by region

\begin{tabular}{|c|c|c|c|c|c|c|}
\hline \multirow{2}{*}{ Region } & \multirow{2}{*}{$\begin{array}{l}\text { Number of } \\
\text { institutions }\end{array}$} & \multirow{2}{*}{$\begin{array}{c}\text { Average size of } \\
\text { enrolment } \\
\text { (Students/TVET) }\end{array}$} & \multicolumn{3}{|c|}{ Number of students } & \multirow{2}{*}{$\begin{array}{l}\text { Gender } \\
\text { Ratio }^{*}\end{array}$} \\
\hline & & & Total & Female & Male & \\
\hline North & 1 & 636 & 636 & 216 & 420 & 0.51 \\
\hline Central & 2 & 328 & 656 & 190 & 466 & 0.41 \\
\hline South & 2 & 545 & 1,090 & 312 & 778 & 0.40 \\
\hline Total in country & 5 & 476 & 2,382 & 718 & 1,664 & 0.44 \\
\hline
\end{tabular}

Note: Gender ratio = number of female/male students in each region.

Source: Author's illustration based on data from MAF (2008, p. 10).

Overall, it can be said that a large proportion of Lao youth are engaged in industrial and service sector-related programmes, leaving relatively few in the agricultural sector. There is also an interesting pattern in that while the industrial sector-related programmes are predominated by male students, service sectorrelated programmes are predominated by female students.

It can also be seen that the Lao government has faced several challenges in the improvement of TVET. The overall performance, for instance, is relatively low and the implementation of a new qualification framework is required. And yet budgetary support is limited. The government, therefore, requires external funding to improve and expand TVET in the country. The following section examines governmental (mainly, MOES and MAF) development plans and key donor projects that have supported TVET development in Laos.

\subsection{Public TVET development}

\subsubsection{Government development plans, strategies and funding}

In the late-1990s, MOES published its first Strategic Plan for the development of Technical and Vocational Education and Training (TVET Strategic Plan). This plan, however, is "no longer [relevant]" to the current socio-economic development

\footnotetext{
${ }^{4}$ Note that there is a limit in getting access to more updated information on agricultural education.
} 
agenda (MOE, 2007b, p. 4). A new long-term Strategic Plan (2006-2020) was, therefore, developed in 2006 (MOE, 2007b). The Master Plan for the Development of TVET (2008-2015) was subsequently prepared to operationalise the new Strategic Plan (MOE, 2007a).

MOES views TVET as "an integral and crucial part of the national education system, and as a means for preparing the workforce and technicians at various levels for employment [through] training so that they are equipped with necessary knowledge, abilities, skills, and attitude" (MOE, 2007b, p. 10). The main objective of TVET development is to "prepare human resources that meet the needs of the labour market," contributing to the "implementation and achievement of national socio-economic development goals, the National Growth and Poverty Eradication Strategy (NGPES), and the process of industrialisation and modernisation of the country" (MOE, 2007b, p. 4).

Guided by the Education Sector Development Framework (ESDF, 20092015) (MOES, 2009), the Master Plan aims to (i) increase equitable access to education, (ii) improve quality and relevance, and (iii) strengthen management and administration of education (MOE, 2007a). To achieve these aims, seven strategies (to be presented later) and more than 100 activities were outlined in the Master Plan.

Funding for this Master Plan derived from two main sources-the government and development partners (aid donors) ${ }^{5}$. The total budget required for the implementation of the plan was US\$172.42 million. Of the total amount, 91 percent of the budget was allocated for investment costs, and 9 percent was allocated for recurrent costs, including salaries, basic equipment, and staff development (MOE, 2007a). However, the budget was inadequate at the time the plan was published, and only 14 percent of the budget was granted by donors (MOE, 2007a).

The Ministry of Agriculture and Forestry (MAF) has the major responsibility for vocational agricultural education and training. With the support of the Swiss Agency for Development Cooperation (SDC), a strategic reform of agricultural TVET colleges in Laos was published in 2007 for the first time (MAF, 2008). Key objectives of this reform strategy are "to develop skilled-human resources for market-based development in the agricultural sector, and to "improve the quality of

\footnotetext{
${ }^{5}$ Development partners include aid donors and experts who support the government of Laos. Thus, in this research I use the term 'development partner' and 'aid donors' interchangeably.
} 
teaching and learning in technical education at the agriculture and forestry colleges" (MAF, 2008, p. 4).

The funding mechanism in agricultural education slightly differs from what exists in the MOES's system. While the main source of funding is the government's responsibility, the collection of student registration fees, the investment from the private sector, and the selling of college products are the main sources of income for TVET development in the agricultural sector (Fig. 4.6) (MAF, 2008). The central idea, according to MAF (2008), is to ensure 'self-reliance,' rather than aiddependency. This approach seems to be a sustainable way of maintaining TVET development.

Fig. 4.6 Percentage of shared costs for agricultural TVET development

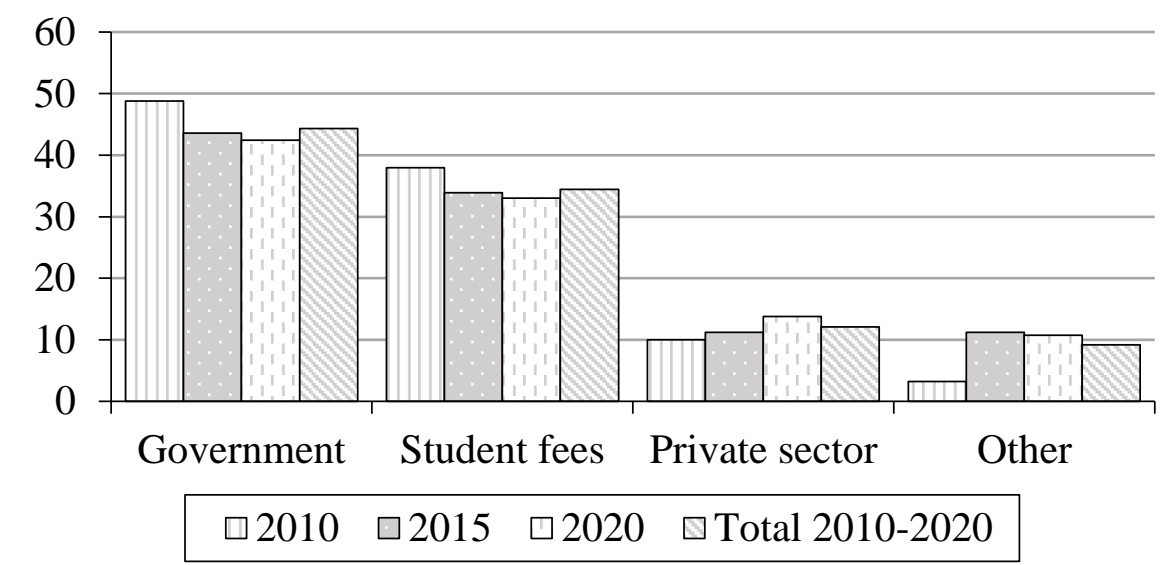

Source: Author's illustration using data from MAF (2008, p. 32).

\subsubsection{Donors' development projects, strategies and funding}

This section provides information about three external projects that have supported TVET development in Lao PDR, and more specifically the two colleges I visited in Luang Prabang. Therefore, it is worth underlining the project objectives and funding mechanisms so that the reader will appreciate that the change occurs on the ground. Note that these projects were funded and implemented by multilateral and bilateral agencies and a non-government organisation (NGO).

To begin with, in the late-2000s, there was a shift in the way education was financed and supported by some donors in Laos, moving from the focus on basic education to TVET development. In 2007, the Swiss Agency for Development Cooperation (SDC) began to provide consultancy support to MAF for agricultural 
education and training reform (MAF, 2008). The "Strategy for Reform in the Agriculture and Forestry Colleges (2008-2020) in Lao PDR" was published in 2008. Funded by SDC and implemented by HELVETAS, the SURAFCO project (Support to the Reform of the Northern Agriculture and Forestry College in Laos) was then developed to particularly support this reform. The project consists of two phases: 2009 to 2011 and 2012 to 2016 (SDC, 2009, 2012).

Strategically, the project supports, firstly, the Northern Agriculture and Forestry (NAFC) in Luang Prabang to become an 'excellent' institution before expanding the model to other colleges nationwide (SDC, 2009). The central aim of the project was to ensure NAFC is "a well-managed centre for skills-based education and training in upland farming systems" (SDC, 2009, p. 21). The SURAFCO project was designed to include gender equity and human-rights aspects in the implementation of the project, more specifically, in the teaching and learning environment. SDC, as a donor, wishes to empower students, especially women from remote areas and ethnic backgrounds through this process (SDC, 2012).

In 2010, ADB began to shift its development assistance to Laos from basic education development to focusing on post-basic education (ADB, 2010b). ADB views TVET as an important instrument to create "a significant impact on both productivity and poverty reduction" (ADB, 2010b, p. 2). In supporting the government's development priority of TVET, ADB launched a Strengthening Technical and Vocational Education and Training Project (STVET) to span the period from 2010 to 2016 (ADB, 2010a). The project aimed at improving "the quality of and access to formal TVET in Lao PDR, focusing on certificate and diploma programmes" (ADB, 2010a, p. 1). By the end of the project, ADB expected to see a more highly skilled and diverse workforce in the country, and a formal vocational training system that was "more accessible, relevant and responsive to the labour market needs" (ADB, 2010a, p. 111).

Crucially, ADB acknowledges the importance of indigenous people/ethnic groups, and a specific plan was developed to ensure that ethnic students are able to “access and complete a TVET education" ADB (2010a, p. 135). It is expected that after their graduation, they will have access to the mainstream labour market (ADB, 2010a). Note that the project's target areas were Luang Prabang (northern region), Savannakhet and Champasack provinces (southern region), and Vientiane capital 
(central region). In the northern region, Luang Prabang TVET was the only college that received some support from the project (ADB, 2010a).

In 2013, the Deutsche Gesellschaft für Internationale Zusammenarbeit (GIZ) and SDC co-financed a programme, Vocational Education in Laos (VELA), to reform the vocational education system in Lao PDR (GIZ, 2014; SDC, 2017). The programme began in December 2013 and will end in August 2018 (GIZ, 2016b). The programme aims to support the Lao government's efforts "to change its TVET policy from a supply-driven to a demand-driven approach" (GIZ, 2016b, p. 1). In so doing it supports regulatory framework improvements and the involvement of the private sector in the design of curricula in order to ensure the learning outcomes more closely meet the needs of the labour market (GIZ, 2016b).

The programme also aims to "specifically accommodate disadvantaged groups ${ }^{6}$ to ensure a socially inclusive system" (GIZ, 2016b, p. 2), and to "make a last contribution towards meeting the quantitative and qualitative needs of the labour market" (GIZ, 2016a, p. 4). An Inclusive Access Fund (IAF), a scholarship programme that directly support TVET institutions, is used as an approach to assist these disadvantaged groups, including out-of-school children (GIZ, 2014, 2016b). It is expected these target beneficiaries will achieve at least two levels of nationally recognised certification (Certificate 1 and 2), as well as specific trades, life skills, and financial literacy trainings (GIZ, 2016b).

Overall, we can see that each project has its own objectives and target areas. However, the collective trajectory of these objectives all target the goals of poverty reduction and economic prosperity for the country. TVET development objectives and strategies that exist in the above three projects and the government reform paper (MAF) and development plan (MOES) can be summarised in Table 4.7 below.

\footnotetext{
${ }^{6}$ In Laos, 'disadvantaged groups' is a general term referring to people from impoverished families, or who live in remote and isolated areas, or those with special needs. In the education context, disadvantaged groups also refers to leaners who encounter learning difficulties due to their physical, economic, and/or social status (Lao PDR, 2014).
} 
Table 4.7 TVET development objectives and strategies in Lao PDR

\begin{tabular}{|c|c|}
\hline $\begin{array}{l}\text { Development } \\
\text { objectives }\end{array}$ & TVET strategy \\
\hline $\begin{array}{l}\text { Expand equitable } \\
\text { access }\end{array}$ & $\begin{array}{l}\text { 1. Improving infrastructure, expanding of TVET offer. } \\
\text { 2. Linking training to the extension system (helping farmers). } \\
\text { 3. Linking training to agro-enterprise development and the needs } \\
\text { of the labour market. }\end{array}$ \\
\hline $\begin{array}{l}\text { Improve quality } \\
\text { and relevance }\end{array}$ & $\begin{array}{l}\text { 4. Improving curriculum from supply-side to demand-side } \\
\text { (labour market-oriented) approach and from teacher-centred } \\
\text { to student-centred teaching approach. } \\
\text { 5. Strengthening capacity of teaching staff through trainings. } \\
\text { 6. Improving qualifications framework and quality assurance } \\
\text { systems. } \\
\text { 7. Ensuring the relevance of curriculum to the rural livelihoods } \\
\text { (upland agriculture). }\end{array}$ \\
\hline $\begin{array}{l}\text { Strengthen } \\
\text { planning and } \\
\text { management }\end{array}$ & $\begin{array}{l}\text { 8. Improving the management and governance of TVET. } \\
\text { 9. Regulating policy and legal frameworks of TVET. } \\
\text { 10. Promoting of self-reliance, accountability, transparency, and } \\
\text { gender-senility of TVET management. } \\
\text { 11. Increased private sector involvement in TVET strategy and } \\
\text { delivery. } \\
\text { 12. Building capacity of government institutions to ensure } \\
\text { effective project management and implementation. } \\
\text { 13. Partnering with private sector and farmers to contribute to a } \\
\text { better outreach in offering quality services for upland } \\
\text { development. }\end{array}$ \\
\hline $\begin{array}{l}\text { Inclusion, equity, } \\
\text { and social } \\
\text { justice }\end{array}$ & $\begin{array}{l}\text { 14. Introducing human rights-based and integrated approaches in } \\
\text { TVET development. } \\
\text { 15. Ensuring disadvantaged and ethnic groups, especially women, } \\
\text { are included and benefit from the development initiatives. }\end{array}$ \\
\hline
\end{tabular}

Source: Author's summary based on project documents and policy papers from MOE (2007a, 2007b); GIZ (2014, 2016b); MAF (2008); SDC (2009, 2012).

The external funding mechanism for TVET development in Laos is relatively complex. SDC funding falls under bilateral assistance, and comes in the form of grants (SDC, 2009, 2012). ADB provides grants through the Official Development Assistance (ODA) (ADB, 2010b). GIZ and SDC's co-funding of the VELA programme is also in the form of bilateral assistance, but implemented by an NGO (GIZ, 2014, 2016b). Table 4.8 below provides the total cost of funding, and the proportion shared by each institution, summarised from information presented earlier in respect of the three projects. 
Table 4.8 External and internal funding for TVET development in Laos

\begin{tabular}{|c|c|c|c|c|c|c|}
\hline & \multicolumn{2}{|c|}{$\begin{array}{c}2010-2016 \\
\text { SDC }\end{array}$} & \multicolumn{2}{|c|}{$\begin{array}{c}2010-2015 \\
\text { ADB }\end{array}$} & \multicolumn{2}{|c|}{$\begin{array}{l}2013 \text { - } 2018 \\
\text { GIZ \& SDC }\end{array}$} \\
\hline & $\begin{array}{c}\text { Budget } \\
\text { (US\$, million)* }^{*}\end{array}$ & $(\%) * *$ & $\begin{array}{c}\text { Budget } \\
\text { (US\$, million) }\end{array}$ & $(\%)$ & $\begin{array}{c}\text { Budget } \\
\text { (Euro, million) }\end{array}$ & $(\%) * *$ \\
\hline External fund & 7.09 & 88.66 & 23.00 & 92.74 & 15.50 & 100.00 \\
\hline Govt. contribution fund & 0.91 & 11.34 & 1.80 & 7.26 & 0.00 & 0.00 \\
\hline Total & 7.99 & 100.00 & 24.80 & 100.00 & 15.50 & 100.00 \\
\hline
\end{tabular}

Note: $*=$ converted to million by the author $(1 \mathrm{CHF}=0.95 \mathrm{US} \$)$. This amount excludes technical assistance and overhead costs of the project. ${ }^{*}=$ calculated by author. $\%=$ each type of funding/total budget.

Source: Author's illustration based on multiple sources SDC (2012, pp. 558-559); GIZ (2016a, 2016b); ADB (2010a, p. 15).

Budget allocation by each project/programme differs. For the SUFARCO project, in phase 1, more than 40 percent of the total budget was allocated for administrative costs (SDC, 2009, p. 52). However, in phase 2, the project allocated nearly 90 percent of the total cost for project activities (SDC, 2012). For STVET, more than 70 percent of the total amount was allocated for the improvement of education quality and the expansion of equitable access to TVET. Some of the budget (US\$2,541) was allocated specifically to indigenous/ethnic group development. This amount, however, is equivalent to only 0.01 percent of the total project budget (ADB, 2010a) which seems to be too little to ensure indigenous development activities are implemented. Finally, for the VELA programme, of the total budgeted 15.5 million Euro, 4.8 million Euro was allocated for the Inclusive Access Fund - the scholarship scheme. This amount accounted for 31 percent of the total budget (GIZ, 2016a, 2016b). More contributions from the government, however, shall be encouraged, if project ownership, accountability, and sustainability are to be promoted.

The flow of funding from aid donors to aid recipients is also complex. It involves, on the government side, three different layers - the central, provincial, and school levels (Fig. 4.7). After the Memorandum of Understanding (MOU)/Budget Agreements were signed between aid-donors and the government at the central level, the provincial department and college under their vertical line ministry were informed about the project and together operated it in accordance with the overall guidance of the central ministry and aid-donors. The flow of funds depends on the type of activity too. Sometimes it goes directly to the college, or the scholarship scheme (as in the case of STVET and VELA). Development workers 
of the VELA programme reported that this form of funding is effective as it reaches the hands of the project beneficiaries directly (Interview, 1/8/2016). For the SURAFCO project, the budget first flows from SDC, then to HELVETAS and finally to NAFC. However, as the project was established in NAFC, the budget request process proceeds relatively smoothly, and thus activities can be implemented consistently and effectively (Interview of school director of NAFC, $11 / 6 / 2016)$

Fig. 4.7 Flow of funding for TVET development in Lao PDR

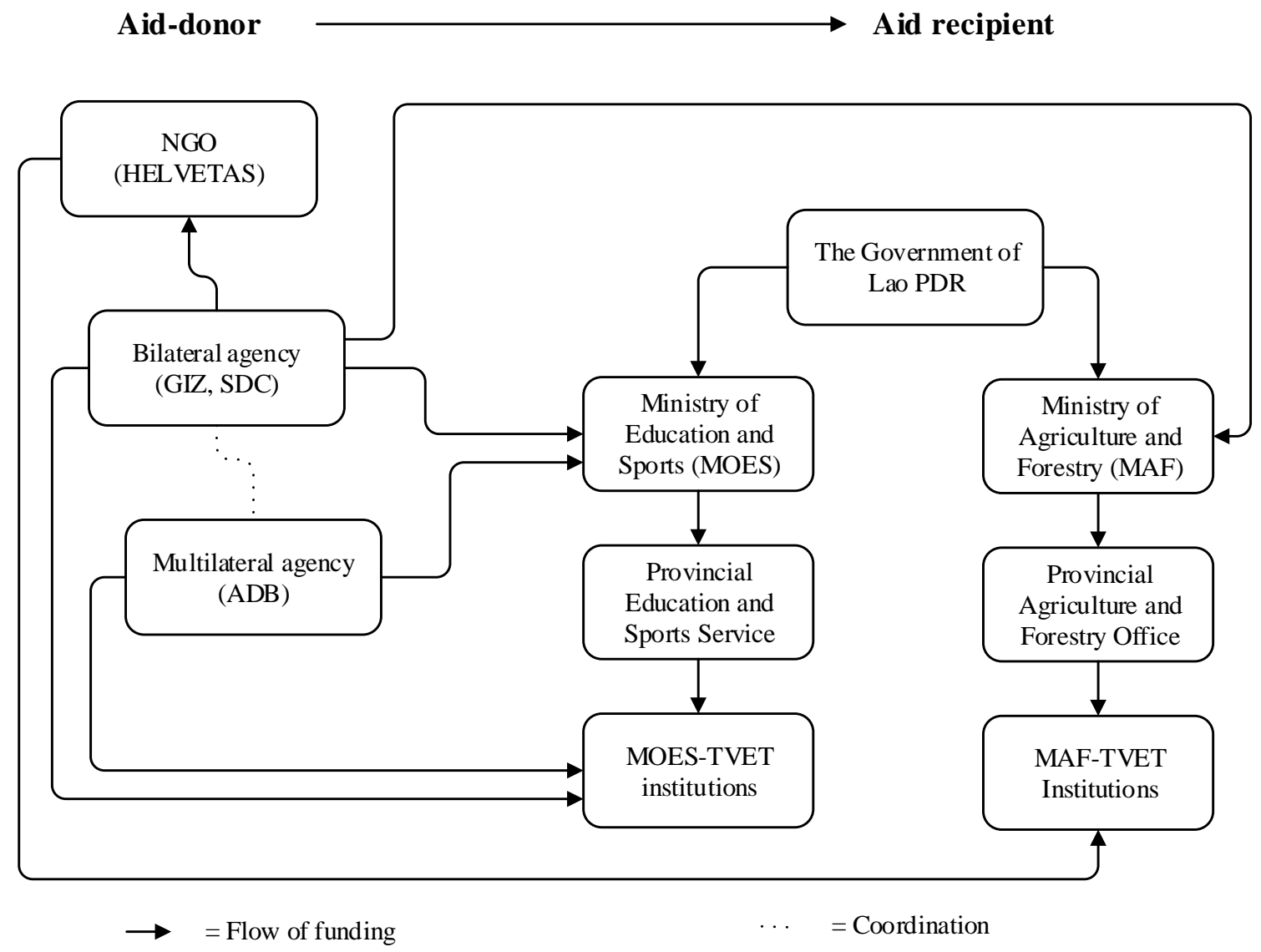

Source: Author's illustration based on several project documents and policy papers from MOE (2007a, 2007b); GIZ (2014, 2016b); MAF (2008); SDC (2009, 2012).

Before summarising this chapter, it is worth providing key information about the TVET institutions I visited in Luang Prabang. As explained in chapter 3, I chose two vocational education and training colleges in this province as case studies of my research. One was the Northern Agriculture and Forestry College (NAFC) which is under the governance of MAF. The college receives external support from 
the SURAFCO project (an SDC-funded project). The other was the Luang Prabang Technical and Vocational Education and Training College (LPB-TVET) which is under the governance of MOES, and receives external support from the STVET (an ADB-funded project). Both colleges receive support from the VELA programme (co-funded by GIZ and SDC).

\subsection{TVET colleges in Luang Prabang province - case studies}

\subsubsection{Northern Agriculture and Forestry College}

When I arrived in the field, the first college I visited was NAFC. This college was officially established in 1989 (NAFC, 2014). When it was first established, its aim was to build the capacity of extension officers in the agricultural sector across the northern region of Laos in order to support famers improving their farm activities (NAFC, 2014). Its aim, however, began to change with the introduction of MAF's strategy reform to the college in 2010. A new vision of the college was then set as follows (NAFC, 2014, p. 4):

The Northern Agricultural and Forestry College is acknowledged by public and private partners as a centre of excellence in sustainable upland farming systems, offering skills-based and market-oriented education, training and services, thus contributing to poverty reduction, food security and income generation in the Northern Provinces of Laos.

Influenced by the strategic reform, the key objective of NAFC is to "develop skilled human resources for market-based development in the agriculture sector" (NAFC, 2014, p. 6). A larger role of NAFC is to deal with issues around sustainable upland farming systems, skilled-based and market-oriented education and training, food security, income generation, and poverty reduction in the region (NAFC, 2014).

The NAFC offers three-year programmes for higher diplomas in Applied Agronomy, Livestock and Fisheries, Forestry, Agribusiness. Additionally, the college offers a 1.5-year programme (continuing/upgrading programme) for students who have taken a medium diploma and wish to complete a higher diploma. Students, especially women, from poor families and ethnic minority backgrounds are encouraged to apply to all available programmes in this school. In terms of teaching methods, a balanced approach between theory and practice is used- 
programmes comprise 40 percent theory and 60 percent practical application of knowledge and skills. A student-centred learning approach has also been applied. This only happened after the introduction of the new strategic reform, and started with the 2010-2011 academic year (Interview of school director, 10/6/2016).

Enrolment in the NAFC was slightly low prior to 2010, thanks to a high dropout rate (approximately 10 to 25 percent). However, since 2011, student enrolment in this school had increased dramatically, partially because of a scholarship programme supported by the SURAFCO project (HELVETAS, 2015). By gender, male students were predominant. However, the number of females enrolled has increased significantly over the past six years and in contrast with male student enrolment trends (Fig. 4.8).

Fig. 4.8 The enrolment trends of NAFC's students by gender

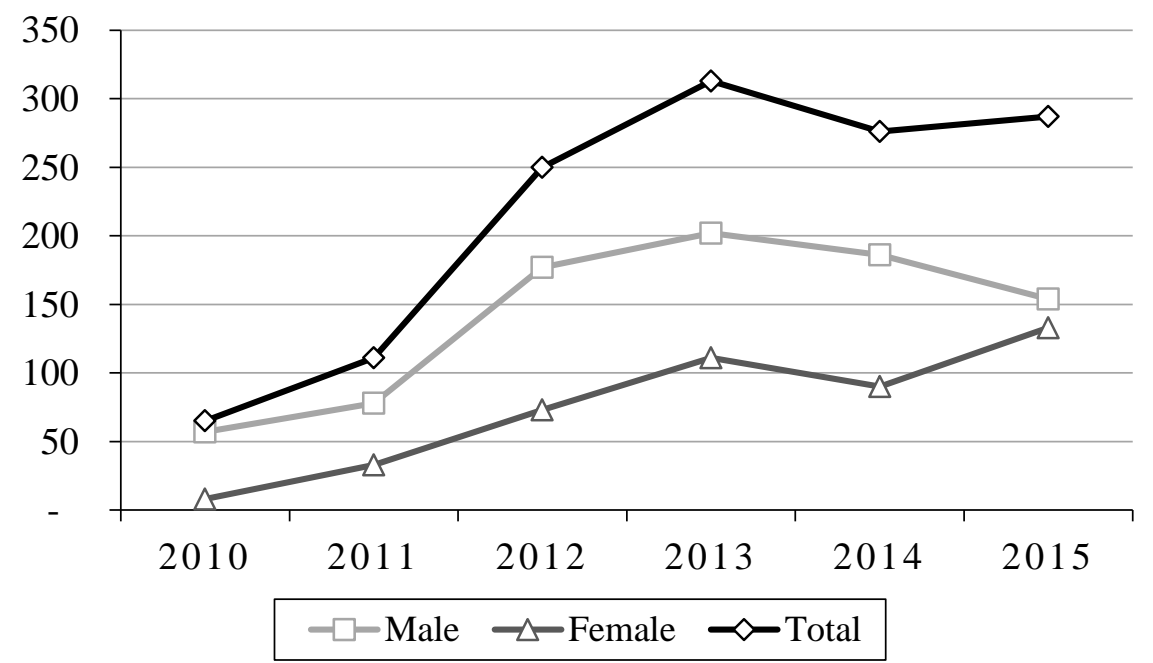

Source: Author's illustration using data from HELVETAS (2015, p. 27).

By ethnic group, Lao-Tai student enrolment dominated all other ethnic groups combined (Fig. 4.9). However, there was a considerable increase in the number of Kmhmu students enrolled, while there was little increase among Hmong ethnic students. 
Fig. 4.9 The enrolment trends of NAFC's students by ethnic group

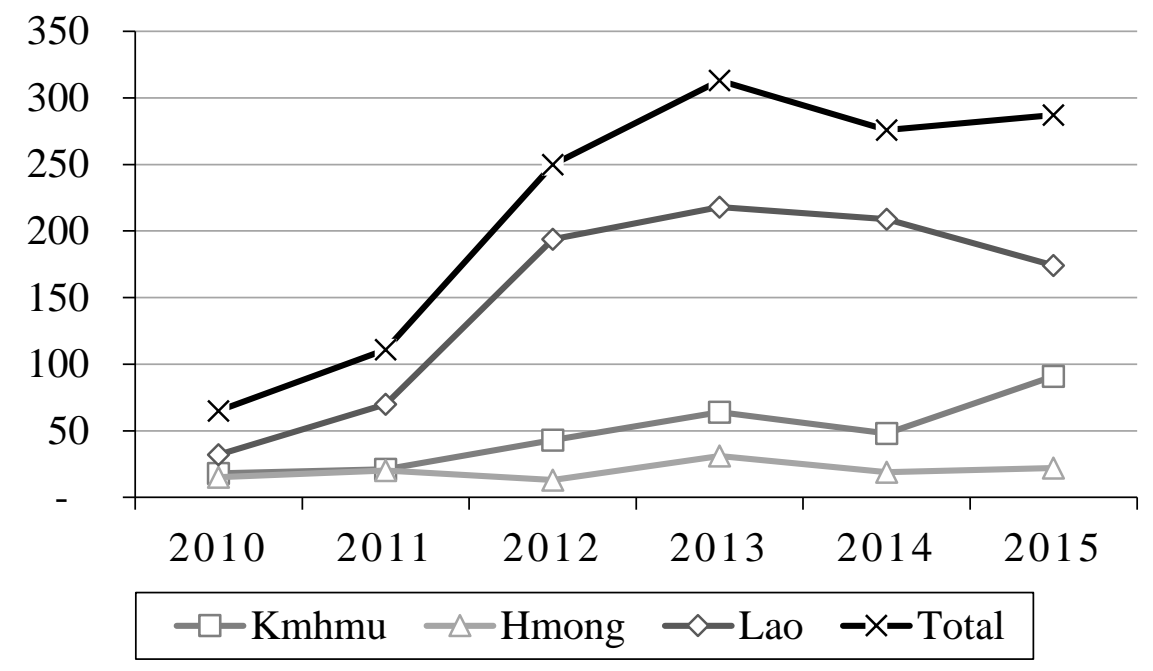

Source: Author's illustration using data from HELVETAS (2015, p. 27).

\subsubsection{Luang Prabang TVET College}

After meeting the people at NAFC, I visited Luang Prabang TVET (LPB-TVET). The college was constructed in 1968 and finished in 1973. It has then grown relatively quickly, and has expanded its branch in a rural district of Luang province (Konepachit, n.d). According to the director, the college has two key missions:

First, it is committed to train students to have a better understanding of a political vision of the country, to have a proper manner [morality], to become good citizens, to love the nation, and to believe and trust the new government regime under the leadership of the Lao PDR Revolutionary Party. Second, it is committed to provide technical and practical skills and knowledge so that students can contribute to the development of the country after graduations (Interview, 21/6/2016).

The college, he continues, also has overall roles and responsibilities in the development of skilled-human resources for public and private sectors at the provincial, national, and regional (Southeast Asia region) levels. It can be seen that although LPB-TVET and NAFC have different historical backgrounds and key areas of focus, both aim to prepare human resources for work.

LPB-TVET offers various programmes/courses, mainly related to the industrial and service sectors. The college, according to the director, offers three different levels: primary or first level (upper secondary level), middle level (medium diploma) and high level (higher diploma) (Interview, 10/6/2016). These 
qualifications are equivalent to the levels 3, 4 and 5 of the NVQFs, explained in the previous section, 4.4.2. The college also provides specialised courses for any interested individuals, especially dropout students from primary school and students from disadvantaged, isolated areas. Presumably, these special courses fall under $\mathrm{C} 1$ and $\mathrm{C} 2$ levels. As such, it can be said that the college has already attempted to provide, on a large scale, skills training across multiple levels to people not only within the city of Luang Prabang, but also for people from remote areas and other provinces in the northern region of Laos.

The college has achieved a high performance in the past half-decade. The number of enrolments increased from 1,376 in 2010 to 1,692 in 2015, despite the decrease between the 2011 and 2014 academic years (Fig. 4.10). Although the number of male students was larger than female students, women's enrolment has increased significantly since 2014. It is reported that the increase in student numbers was partly due to the Social Marketing Campaign (SMC), supported by the STVET project (Interview with school director, 10/6/2016). More on the SMC will be discussed in chapter 7

Fig. 4.10 The enrolment trends of LPB-TVET by gender

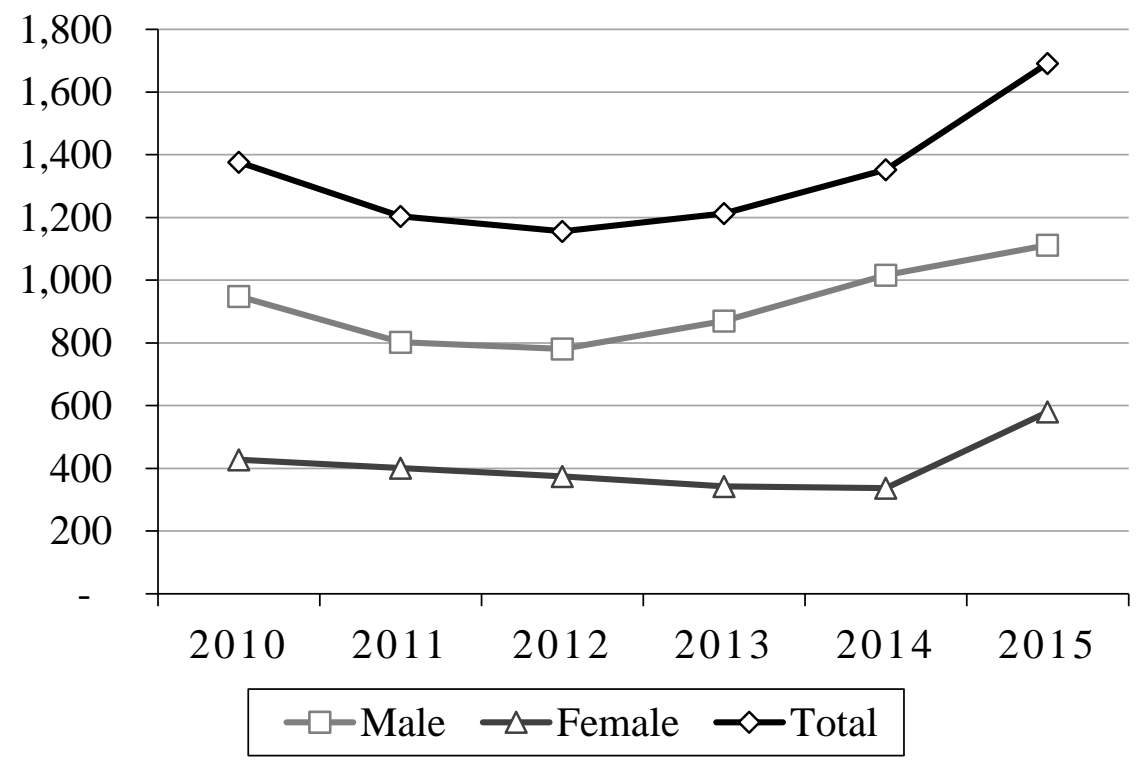

Source: Author's illustration based on data from MOES (2013, 2015b).

Interestingly, there is a significant difference in enrolment trends by sector, by programme, and by gender. In 2015 alone, for example, a large proportion of male students enrolled in the industrial sector (Fig. 11), whereas female students 
were predominant in the service sector (Fig. 12). According to MOES (2015b), female students' enrolment in the industrial sector was less than 2 percent in 2015, whereas their enrolment in the service sector was more than 50 percent. The enrolment trend in this college is similar to that of the country as a whole, as explained earlier. The enrolment trend in these two colleges reinforces the argument made earlier that more expansion on agricultural TVET is needed.

Fig. 4.11 Number of students enrolled in the industrial sector by gender

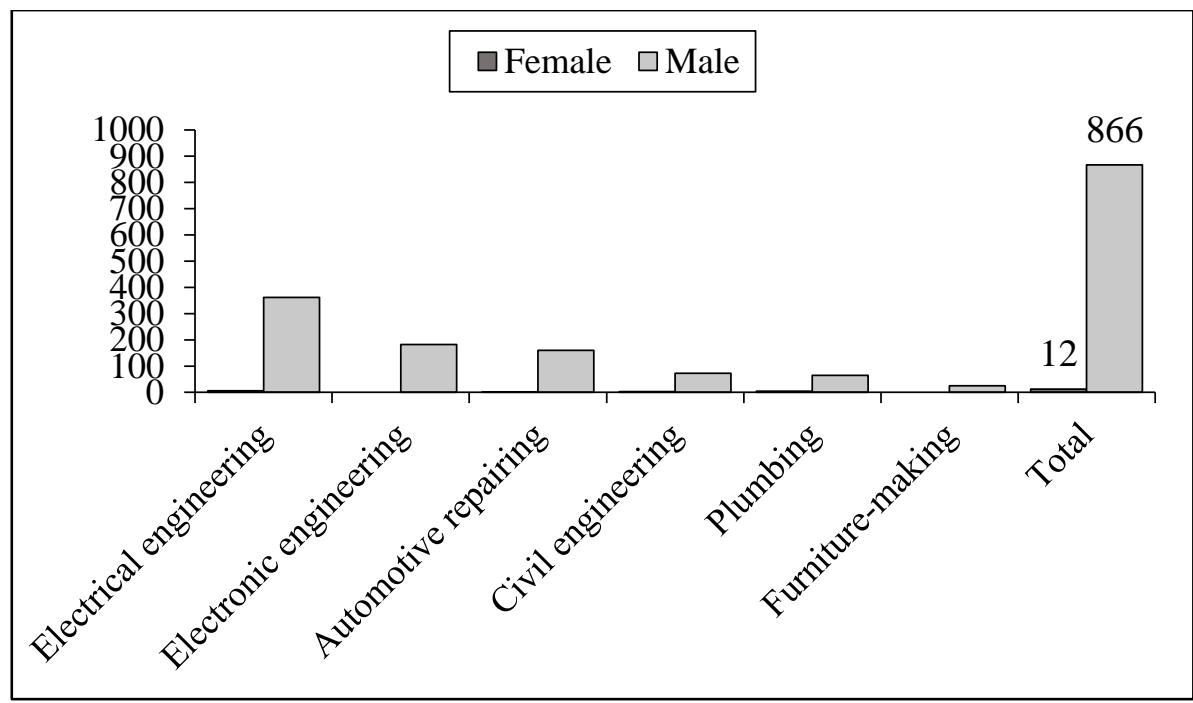

Source: Author's illustration based on statistics from MOES (2015b).

Fig. 4.12 Number of students enrolled in the service sector by gender

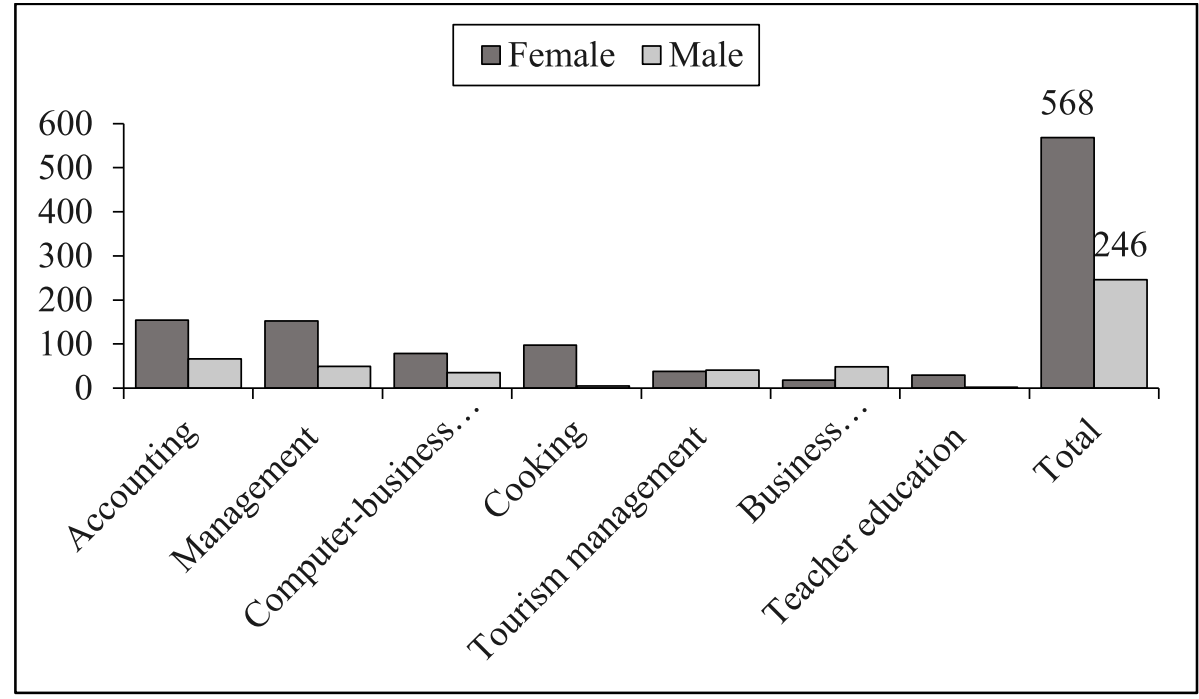

Source: Author's illustration based on statistics from MOES (2015b). 


\subsection{Summary}

In summary, Laos has a long history of development which can be dated back to the mid-1970s when the country fully received its independence from the Europeans. The historical and political accounts have influenced the way in which socio-economic development policy is framed and the impacts the policy may create at the grassroots level. Although attempts have been made to improve the economy and to reduce poverty in the country, several challenges remain. Many rural youth have engaged in unproductive agriculture and are unskilled labour, thus locking them into the cycle of poverty, mainly due to their lack of education and training. The government, with the support of its development partners, has developed several plans to improve the education sector, especially TVET, thus aiming to enlarge livelihood choices and opportunities for rural youth. The extent to which these plans and strategies are relevant to the current livelihoods of the local people, especially the young, has not yet been examined. This is a key concern of this research and it will be discussed in the subsequent chapters. 


\section{Chapter 5 Livelihood activities and challenges in rural villages}

\subsection{Introduction}

This chapter attempts to provide answers to the first research sub-question: 'How are the current livelihoods of local people arranged in Luang Prabang province?' Transect walks conducted in Huayman and Meuang Ngoy villages, and interviews of eight local people (including a village head, elders, community members, and a school leaver), are used for the analysis in this chapter. Where relevant, studies elsewhere are included in order to provide insights about the topic being discussed. Crucially, the chapter also examines the extent to which the New Economic Mechanism (NEM), explained in chapter 4, has influenced the livelihood arrangements of the two villages. The bringing of this policy into the discussion is based on what has emerged from the fieldwork.

Employing a sustainable livelihood framework, the chapter examines what local people do to secure their livelihoods, how they do it and why. The research reveals that while some have shifted their livelihoods from subsistence, or from farm- to non-farm based systems, others remain unchanged. The finding shows that livelihood systems developed and practised in the villages have been significantly influenced by the historical, social, cultural and economic factors, including the government's policy, especially the NEM. With the challenges faced by local people who rely on existing livelihood systems, it seems that education and outmigration are seen as new livelihood strategies for many rural households.

The chapter proceeds as follows. Section 5.2 clarifies some key terms used in this chapter, and throughout the research. Section 5.3 provides historical, social, economic backgrounds of the two villages. Section 5.4 analyses livelihood activities, and section 5.5 highlights key livelihood challenges facing local people in the two study villages. Finally, section 5.6 concludes the chapter. 


\subsection{Clarification of term use - village and household classification}

It is essential to understand village and household classifications in the context of Laos before moving into the details of the two study villages. In the present study, a village will be considered as urban, if (i) the village is situated in a district or provincial centre; (ii) more than 70 percent of total households in the village use electricity; (iii) more than 70 percent of total households in the village use piped water; (iv) the village is accessible by road in two seasons; and (v) the village has a permanent market operating the whole day (Lao Statistics Bureau, 2016). Any village that does not meet three or more of these five criteria is considered as rural (Lao Statistics Bureau, 2016).

A village will also be classified as poor, if it has (i) more than 50 percent of poor households; (ii) has no primary school, or if children have to walk more than an hour to go to school; (iii) has no village medicine box or pharmacy, or if it takes more than two hours to reach a nearby health centre; (iv) has no clean water; and (v) has no road access, or can be accessed only one season (dry season) in a year. Any village that performs beyond these criteria is classified as non-poor (Lao PDR, 2013).

A household in a rural area is classified as poor if the monthly income of each member in the family, regardless of gender, is less than 180,000 Kip [US\$22.5] (Lao PDR, 2013). A household that earns more than this standard is considered as non-poor. A household will be classified as well-off if everyone in the family (i) has stable income and earns more than US\$22.5 per month, (ii) is aware of the political will and directions of the government, (iii) maintains unity and solidarity in the family, (iv) follows the rule of law, and (v) is aware of gender equality issue and domestic violence (Lao PDR, 2013).

\subsection{Village history and characteristics}

\subsubsection{Huayman village}

Huayman village, or Ban Huayman, was founded in the early 1960s (Interview with Phan, elder of the village, 1/7/2016), and is classified as rural, according to the Governor Office of the Phonxai District (Visited, 29/6/2016). The village is situated in the north-west of Phonxai district, $14 \mathrm{~km}$ from the district centre, and $50 \mathrm{~km}$ from Luang Prabang city. From the village to Luang Prabang city, it takes around one 
and half hours by bus, or Songthaew, ${ }^{7}$ or around 30 minutes to the district centre (Fieldnotes, 2016). Although road conditions were quite good and accessible throughout the year, public transport was available only as a round trip per day (Fieldnotes, 2016). Villagers often commute using their own motorbikes.

According to Jen, the village head, the Kmhmu ethnic group is the indigenous people in this village. As of 2016, the total village population was 374 people, 170 of whom were female. The majority of the population are Kmhmu, accounting for 90 percent of total households. The remaining segment are Lao and Hmong ethnic households (Fig. 5.1). Based on the number of households and the total population in the village, the average household numbers approximately 7 persons.

Fig. 5.1 Number and percentage of households, by ethnic groups

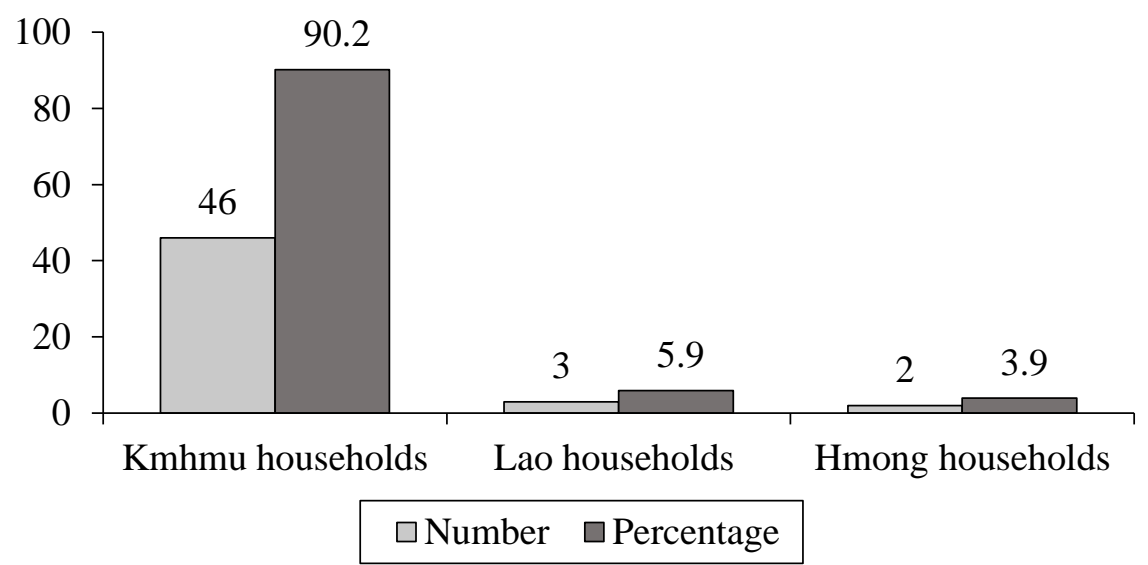

Source: Author, based on the interview with the village head (1/7/2016).

According to the Governor Office of Phonxai District (Visited, 29/6/2016), Ban Huayman was classified as poor. Of the total 51 households, around 65 percent were poor, 29 percent were non-poor, and 6 percent were well-off (Interview with village head, 1/7/2016) (Fig. 5.2).

\footnotetext{
${ }^{7}$ A Songthaew is a pick-up truck converted into a share taxi, or minibus. It is popularly used in rural areas of Laos.
} 
Fig. 52 Number and percentage of households, by socio-economic status

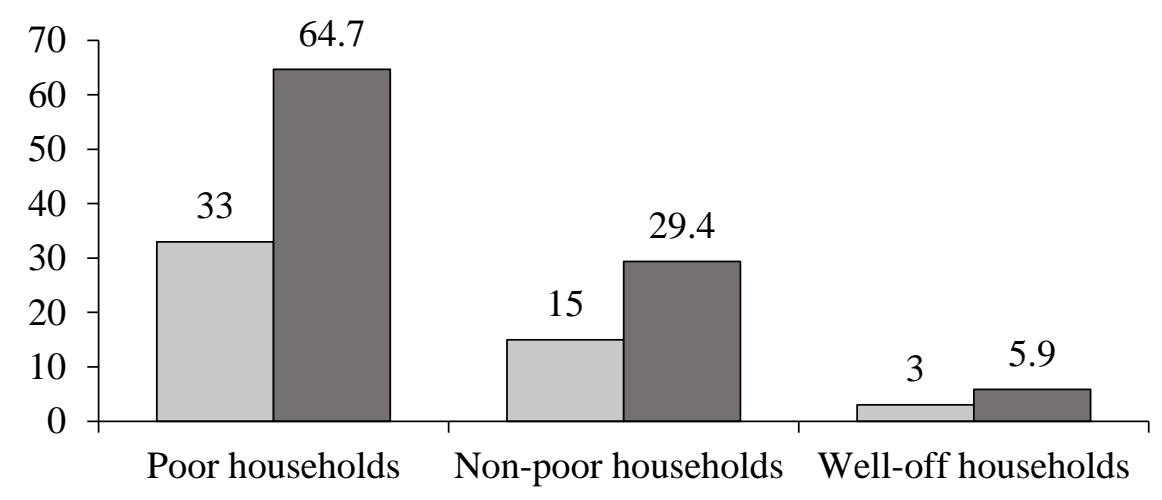

$\square$ Number $\square$ Percentage

Source: Author, based on the interview with the village head (2016).

Ban Huayman is located on the road side which allows the inhabitants of the village to purchase and exchange goods and services in Phonxai district, or Luang Prabang city more easily. Electricity is available almost in every household. Water taps (using a water-fed gravity system) are established in certain places, and each can provide for approximately seven to ten households. A primary school is located within the village's vicinity. There is no secondary school in the village. Therefore, once children complete their primary education, they attend the nearby secondary school at the Bo village cluster (Kum-ban). The distance from the village to this school is around $3 \mathrm{~km}$, requiring most children to ride bicycles to school. However, some students whose parents cannot afford a bicycle have to walk. At the time of my visit, there was no medicine box, pharmacy, or mid-wife available. Therefore, patients had to go to a health clinic at a village cluster (Fieldnotes, 2016).

\subsubsection{Meuang Ngoy village}

Meuang Ngoy village, or Ban Meuang Ngoy is believed to have been founded as early as the fourteenth century, making the village about as old as the Lao Lane Xang Kingdom; the Lao ethnic group were the indigenous people in this village (Interview with Khamphui, elder of the village, 11/7/2016); see also Philasouk (2015). The village was a former Ngoy district headquarters. In the 1980s or so, the governor of Luang Prabang province shifted the district headquarters to Nong Khiaw - the current district headquarters - partly due to population growth and the need to improve governance and public administration systems. Until recently, 
local people in the region often referred to the village as Ban Meuang Ngoy Kao (Old Meuang Ngoy village) (Fieldnotes, 2016).

Ban Meuang Ngoy is situated in a remote and isolated valley, along the Nam Ou River bank, north of the Ngoy district centre, where it is surrounded by seven large mountains. The total land area of the village is only four hectares (Philasouk, 2015). In terms of population size, in 2015, there were 691 people in total, and 355 people were female which accounted for 51 percent of the total population in the village. There were 134 households with around 95 percent well-off, 3 percent nonpoor, and 2 percent poor (Ngoy RDPRO, 2015) (Fig. 5.3). The average household size is 5 persons per household, two points less than that in Ban Huayman.

Fig. 5.3 Number and percentage of households, by socio-economic status

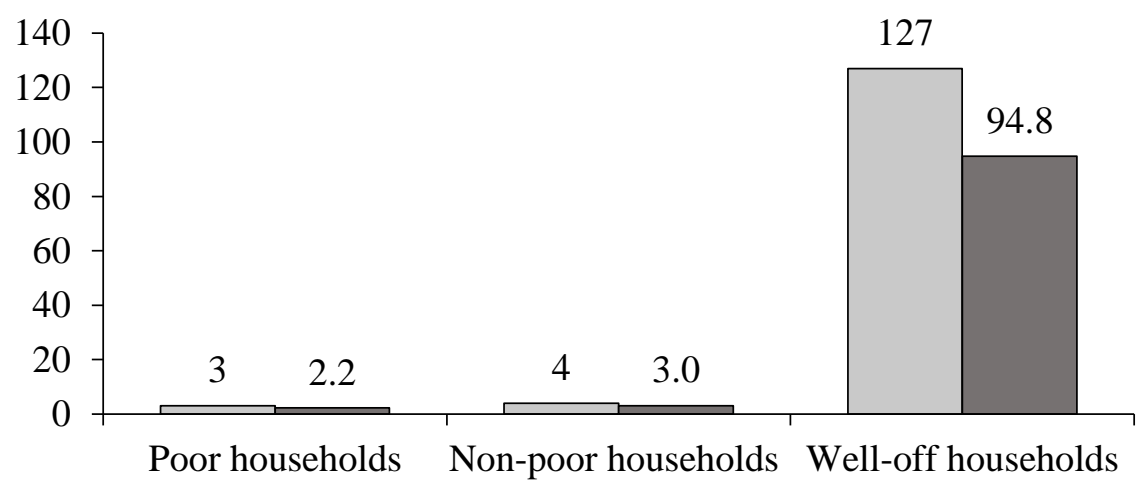

$\square$ Number $\square$ Percentage

Source: Author, based on data from Rural Development and Poverty Reduction Office, Ngoy district, Luang Prabang province (Ngoy RDPRO, 2015).

According to the assessment conducted by the Rural Development and Poverty Reduction Office of Ngoy district (Ngoy RDPRO, 2015), although the village is classified as rural, it is also non-poor as it meets all five indicators set in the National Poverty and Development Standard, as explained earlier. Social services available in the village include schools (from kindergarten to secondary education levels), a health clinic, a pharmacy, public use water taps (most households install water inside the house), and electricity (Fieldnotes, 2016). In the near future, the village is to be upgraded to a 'small rural town' (Ngoy RDPRO, 2015).

Ban Meuang Ngoy can be accessed by boat or road vehicles. Roads can be accessed only during the dry season; hence, most local people prefer commuting by 
river. It seems that river transportation is historically and culturally embedded into the local livelihood system, as boats have been used as the major means of traveling for centuries. Travelling from the village to the district centre (Nong Khiaw) takes less than an hour, and a further three hours by bus to reach Luang Prabang city (Fieldnotes, 2016).

Overall, there are some commonalities and differences between the two villages. Geographically, both villages are situated in rural areas. However, they differ significantly in terms of their history, origins, ethnic composition, culture, and household economic status. These factors may influence the way in which livelihood activities are arranged in each village. Section 5.4 below discusses this in more detail. It also looks beyond the village backgrounds by considering the impact of the NEM, particularly in terms of encouraging a move away from subsistence living to meeting market demands, and the expansion of road access on the premise that these will help to improve local livelihoods.

\subsection{Current livelihood activity and coping strategy}

In this section, I discuss livelihood activities in the two study villages. The section is organised based on the themes of the livelihood activities present. The section contains three subsections. The first two subsections (5.4.1 and 5.4.2) analyse the livelihood activities of the two villages separately. The last subsection (5.4.3) presents a new livelihood strategy by treating the information of both villages together.

\subsubsection{Farm-based livelihoods}

Ban Huayman can be characterised as a village using a farm-based livelihood system. As Kham, a 45 year old member of the village, explained:

Het hai [upland farming], raising livestock, and growing vegetables are the main activities of people in our village. However, as land area is increasingly scarce, there is a decline in upland farming. People grow vegetables, but they mainly grow for household consumption, not for sale (Interview, 1/7/2016).

Jen, the village head, 48 years old, provides additional information regarding livelihood activities in the village. He stated: 
Until today, we [community members] haven't had a new systematic way of making a living. We still follow a slash-and-burn farming system. When we do that, we grow all things in one plot of land, including hot peppers, eggplants, beans, lemongrass, spring onions, maize, Job's tear, and so on.

...when we raise livestock, we raise pigs, chickens, cattle, buffalos, and goats, but we raise only a few of each type: one or two, four or five. However, that keeps us busy all the time and sometimes we cannot manage to do it all. For example, when we go and look after the goats, we miss looking after the cows. When we look after the buffalos, no one looks after our rice farm. When we go to our cassava farm, no one goes to the corn farm (Interview, 1/7/2016).

Jen's quote reinforces Kham's view that the majority of people in Ban Huayman were upland subsistence farmers. Noticeably, livelihood diversification strategies employed by the local people in this village were to grow not only rice, but also to grow supplementary crops in their upland fields. This livelihood strategy seems to be common among Kmhmu. In their studies on the livelihood activities of ethnic groups in Laos, Simana and Preisig (2006) and King and Walle (2012) found that the upland farming system is typical among the Kmhmu ethnic group. Simana and Preisig (2006) further explain that the practice has been rooted in many Kmhmu's livelihood systems. Incorporating the findings of these studies and what I have found in this research (in terms of people's origin, culture, and practice), it can be said that the Kmhmu people in Ban Huayman choose to do upland agriculture system because it has long been embedded into their culture and traditions.

From Jen's point of view, the existing livelihood system needs to be changed. He referred to it as a "traditional livelihood system" (Interview, 1/7/2016). For him, "specialisation" is an alternative to the traditional livelihoods. He explained:

... As we have only a few of each agricultural product, we can only sell a few and gain a small amount of money in return... If we do whatever we specialize in, we will have more and so can sell more. As we can see from business people, they do only one thing and focus on it. Unlike us, we want everything, we do many things at a time, but we can sell little (Interview, 1/7/2016). 
However, the results seemed to be disappointing. He said:

It is very difficult to convince our community members to change from the 'old way' of making a living [subsistence agriculture] to the new one [market-oriented agriculture] because they have gotten used to it and are familiar with it (Interview, 1/7/2016).

It seems that people have resisted the livelihood change, from subsistence farming to farming oriented to market demands, mainly because their existing livelihood system has been culturally embedded. Resistance to this change is not only found in the case of Ban Huayman, but in many other villages in the northern region of Laos as well. In their study, Alexander, Millar, and Lipscombe (2010, p. 63), argue that the livelihoods of local people in the region are "deeply embedded in their cultural and social life" and thus they "steadfastly resist change." Engvall (2006), who investigated the determinants that support livelihood welfare of the poor across the country, also stated that livelihood strategies employed by ethnic groups in Laos are strongly associated with traditions, culture and beliefs. Another recent study, taking in a range of Asian countries, Laos among them, has argued that, for many local communities or Indigenous Peoples, upland farming, or "shifting cultivation[,] is not simply a farming technique but a way of life" as it "is so closely interlinked with lives and cultures", and which is often overlooked by policymakers (Erni, 2015, p. 12).

Resistance to market demands does not mean that livelihood systems are necessarily unsecured. As Jen and Kham explained, when people grow all things in one plot of land, they have direct access to a range of food, and hence nutritional needs are covered, whether they have cash or not. From a food security perspective, this makes more sense than market-oriented strategies.

After the interviews, we conducted transect walks to see where local people grow rice, vegetables, and raise livestock. As time was limited, we could only see places within the village vicinity. Fig. 5.4 below shows an example of how local people grew rice in their lowland areas, supplemented by corn and some sugar cane. Fig. 5.5 is an example of how local people raised livestock such as pigs. Chickens and ducks were raised within that area too. While doing transect walks, I was told that the quality of soil in such land areas was gradually degraded: rice, corn, and 
cabbage growing were not as fruitful. Animals sometimes perished because of diseases.

Fig. 5.4 Rice field with supplementary crops (corn, sugar cane) in Ban Huayman

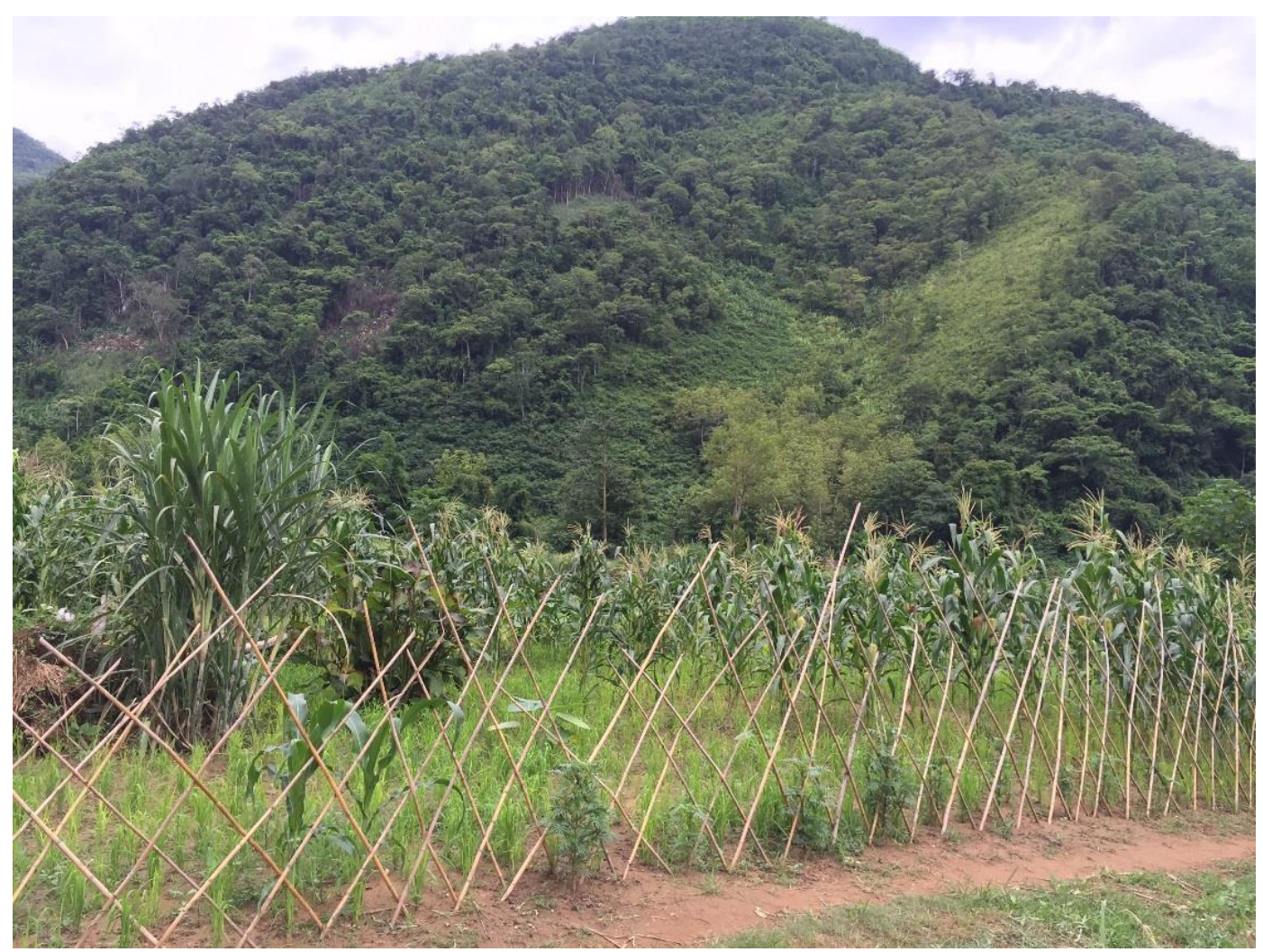

Source: Author (2016) 
Fig. 5.5 Livestock raising farm in Ban Huayman

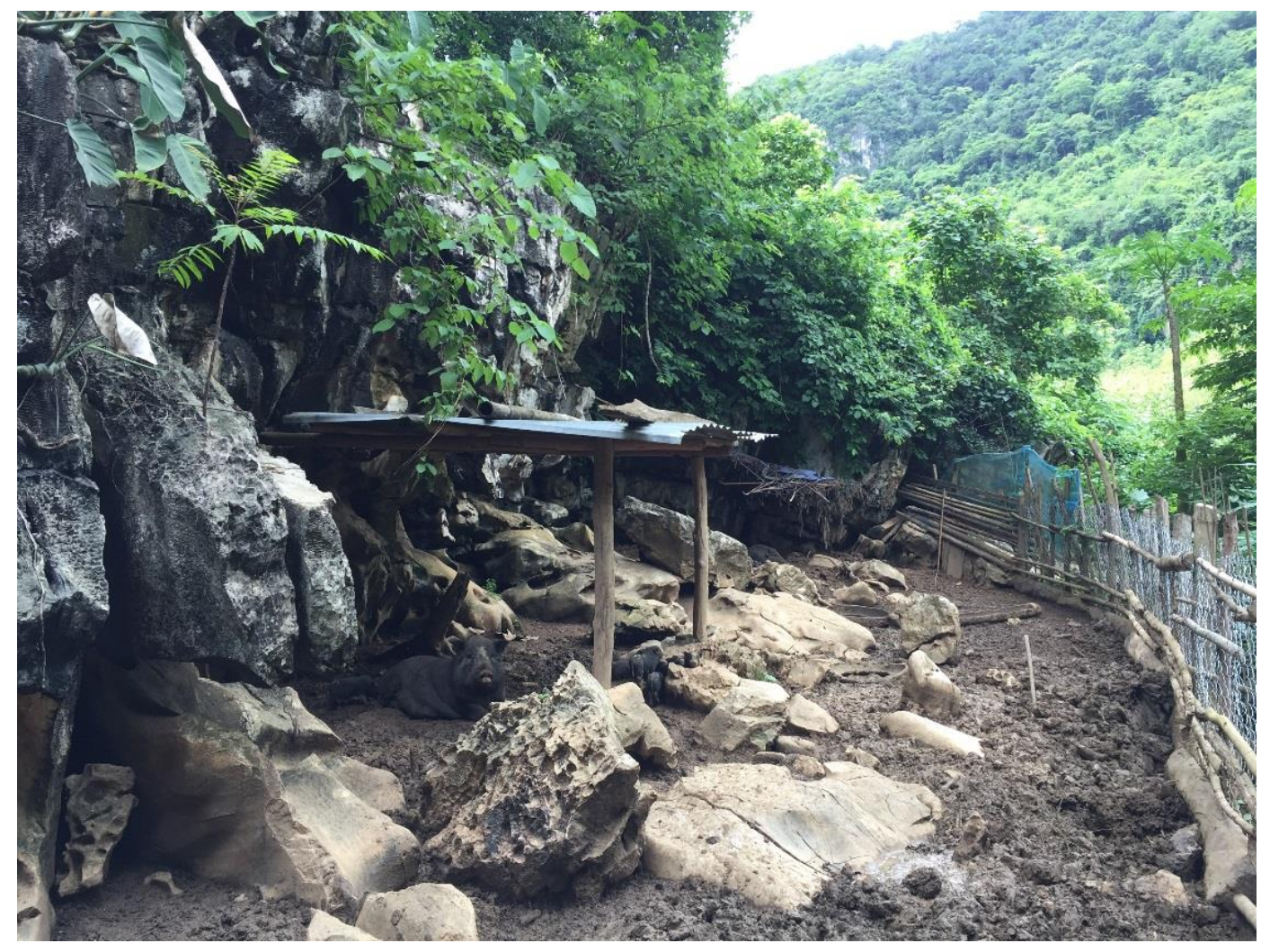

Source: Author (2016)

Besides farming, fishing was the main daily activity for the inhabitants of Ban Huayman. Nam Pa River (Fig. 5.6) and Huayman stream were the only two common places where people go fishing (Interview with Phan, elder, 1/7/2016). According to Phan, the meaning of ' $\mathrm{Nam} \mathrm{Pa}$ ' is the 'river (water) with plenty of fish.' A small stream on the other side of the Nam Pa is called 'Huayman', derived from the name of a particular fish (Pa Man), meaning that this stream was once abundant with fish too. Nowadays, however, fish are rare as many people go fishing (Interview, 1/7/2016). The falling fish stock has led some villagers to rely on the market for food consumption, buying pork and beef from Phonxai district market, for instance (Fieldnotes, 2016). From a sustainable livelihood perspective, better management of local resources is needed if Ban Huayman's livelihoods are to be secured and sustained. 
Fig. 5.6 Nam Pa River in Ban Huayman

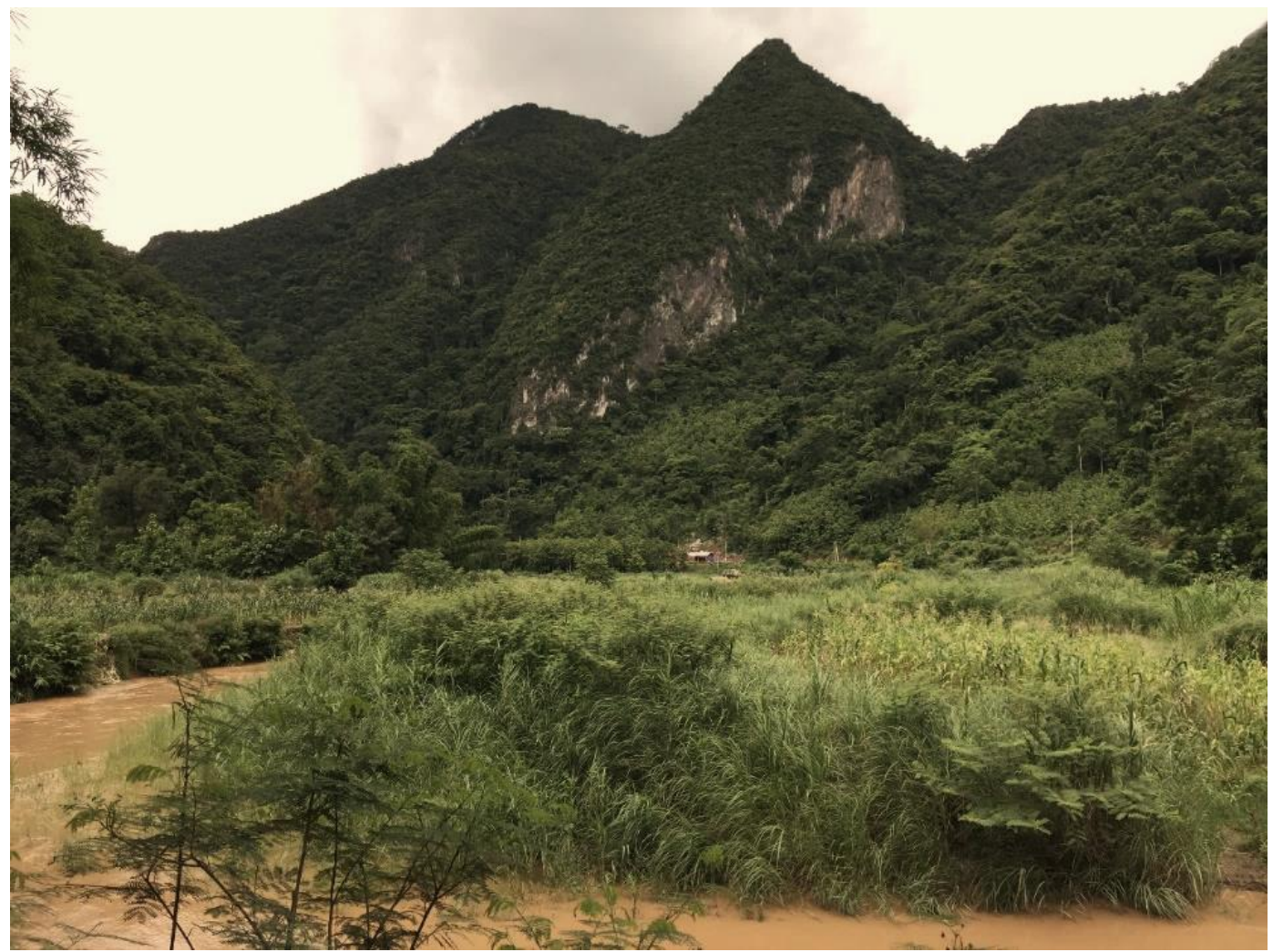

Source: Author (2016)

By way of summarising the livelihood activities of the inhabitants of Ban

Huayman, I categorise livelihood activities based on general classifications: farm and non-farm activities (Owusu, 2009) (Table 5.1).

Table 5.1 Livelihood activities in Ban Huayman

\begin{tabular}{|c|c|}
\hline $\begin{array}{l}\text { Type of } \\
\text { activity }\end{array}$ & Activities \\
\hline Farm activity & $\begin{array}{l}\text { Upland rice during the dry season with some lowland rice during the } \\
\text { rainy season } \\
\text { Vegetable cultivation (cabbage, corn, and choy sum) on the banks of } \\
\text { Nam Pa River } \\
\text { Cultivation of eggplants, chili, sesame, and maize (usually in upland } \\
\text { rice paddy) } \\
\text { Animal husbandry (buffalo, cattle, pigs, and poultry) }\end{array}$ \\
\hline $\begin{array}{l}\text { Non-farm } \\
\text { activity }\end{array}$ & $\begin{array}{l}\text { Casual worker (in Luang Prabang city) } \\
\text { Voluntary work (participating in community and cultural events, } \\
\text { house building, etc.) } \\
\text { Fishing (mainly on Nam Pa River) } \\
\text { Making fishing instruments } \\
\text { Collection of NTFPs (bamboo, wild vegetables, mushroom, etc.) } \\
\text { Teak plantation }\end{array}$ \\
\hline
\end{tabular}

Source: Author, based on Interviews, transect walk, and observations (2016). 
Table 5.1 shows that the inhabitants of Ban Huayman practise mainly farmbased activities, albeit some do take up non-farm activities. According to the data presented earlier, that 65 percent of households are poor, it can be assumed that the farm-activities of these households are unproductive. If the definition of a poor household is to be used here, such unproductive agriculture could also mean that each individual household member was unable to generate income of more than US\$22.5 per month.

The expansion of connectivity (e.g., infrastructure, such as roads), introduced under the economic reform with a view to encouraging more people to access markets, does not seem to have worked particularly well in the case of Ban Huayman. Road access does not necessarily mean that agricultural goods and exchange will be increased. On the contrary, market demand has in fact pushed people to rely on cash, hampering the existing rural livelihood system. This raises several questions. Does NEM promote local development in pursuit of livelihood system sustainability? If not, what should be the alternatives? Should development begin with the local people, owned by the local people, and for the benefit of local people? (Chambers, 1983; Hickey \& Mohan, 2004).

\subsubsection{Non-farm based livelihoods}

Unlike in Ban Huayman, the livelihoods of the inhabitants in Ban Meuang Ngoy have shifted from a farm- to a non-farm system since the mid-1990s. The experience of Ket, a 50 year old woman in Ban Meuang Ngoy, presented below, captures some of the adaptive strategies by which local people have switched livelihood strategies.

Many years ago, the people - both men and women of Ban Meuang Ngoy-used to hai, naa, and $\operatorname{suan}^{8}$ (upland rice, lowland rice, and kitchen garden respectively).

In the 1980s, an integrated farming system was applied - that is, people did not only do hai, but also naa, suan, as well as small trading. The livelihood aspirations of individuals were high, as one person did not do only one activity, but several activities at the same time. Sometimes they succeeded and sometimes failed...

\footnotetext{
${ }^{8}$ hay/hai= Sifting cultivation/mountainous food production for self-sufficiency; souan/Suan = Mixed cultivation: cash crops or kitchen garden; Na/naa = Paddy farming/wetland cultivation/permanent cultivation (see also Khouangvichit, 2010, p. 80).
} 
Later, this practice [of livelihoods] began to change. Each individual began to focus on only one activity, which he/she specialized in...

Nowadays, only a few people do lowland farming, most of them have chosen to do tourist service-related activities. Like myself, I only go to suan or the fish pond to collect vegetables, catch fish, and sell to tourists. Other people, they do weaving or make alcohol to sell to tourists as well (Interview, 10/7/2016).

The above quote can be summarised as follows:

- Prior to the 1980s: households relied on subsistence agriculture, including upland, lowland rice farming, and vegetable gardening.

- During the 1980s: households changed to integrated forms of livelihoods, pursuing subsistence agriculture alongside small trade activities.

- After the 1980s: tourism emerged, prompting many households to shift to non-farm activities, with only some households continuing to practise lowland farming activities

A key factor that led to this livelihood change was the growth of tourism. Khamphui, an elder of the village, explained that:

Prior to the arrival of Western visitors ( $F$ a laang) in around 1995, Meuang Ngoy's villagers did not know what tourism was. When they saw $\mathrm{Fa}$ Laang they were frightened and they wanted to fight them as we used to be invaded by them ${ }^{9}$.

Later, villagers started to understand it. A few people then started preparing rooms in their houses and welcomed visitors to stay and charged them from 10,000 to $15,000 \mathrm{Kip}\left(\sim 1.2\right.$ to $\left.\$ 2.0^{10}\right)$ per night. This way of providing accommodation later became known as "Homestay." Tourism then became a pivotal livelihood strategy among villagers (Interview, 10/7/2016).

According to Khamphui, the inhabitants of Ban Meuang Ngoy seemed to have a high capacity to adapt in respect of livelihood strategies. For instance, local people had changed their perceptions of Western tourists, from "enemies" to "guests". Khamphui further explained that people's perception of foreigners as the

\footnotetext{
${ }^{9}$ Laos' colonial period lasted for several decades (1893-1975). Living under the war for such a long period of time meant that when rural villagers saw Fa laang again, after the war, the natural response was to feel frightened and suspicious rather than welcoming.

${ }^{10}$ The currency exchange rates are estimated based on data from the Bank of Laos. See the website for more detail http://www.bol.gov.la/english/exchrate.html
} 
"enemy" was, in the first place, the result of the legacy of war during the colonial period in Laos (1983-1975) (see also Stuart-Fox, 1997; Stuart-Fox, 2008).

Another example showing the adaptive capability of the local people is that as they went about adapting their livelihoods, they often moved from a position of 'not knowing what to do' to 'learning-to-do' by trying and experiencing. Setting up a spare room for tourists, for example, was the starting point of their learning process towards establishing homestays.

It can be argued that the emergence of tourism in Ban Meuang Ngoy that began in the mid-1990s is a result of the introduction of the NEM in the mid-1980s. The encouragement of foreign investment and opening doors to the Western World have drawn tourists to such a small tiny village. Perhaps, without the economic policy change, the people in this village may have continued to rely on subsistence as they did prior to the 1980s.

Livelihood changes due to tourism have improved the conditions of many peoples' lives in the village. Throughout transect walks with community members after the interviews, I noticed that almost every house in these small villages owned a business, from smaller to larger sizes. What I mean by small businesses are those selling food in the village market, or putting up weaving for sale, or opening minimarts; larger businesses were run by those opening restaurants and owning guesthouses, or operating home-based travel agencies. I also noticed that the food available in restaurants ranged from traditional to western; money exchange services were present; photocopy services and a pharmacy were in place; and music ranged from traditional to Western (see Fig. 5.7 as an example). Perhaps improvements in economic activity have increased the welfare of more than 90 percent of households to become well-off, as presented earlier. 
Fig. 5.7 Examples of rural tourism services in Ban Meuang Ngoy

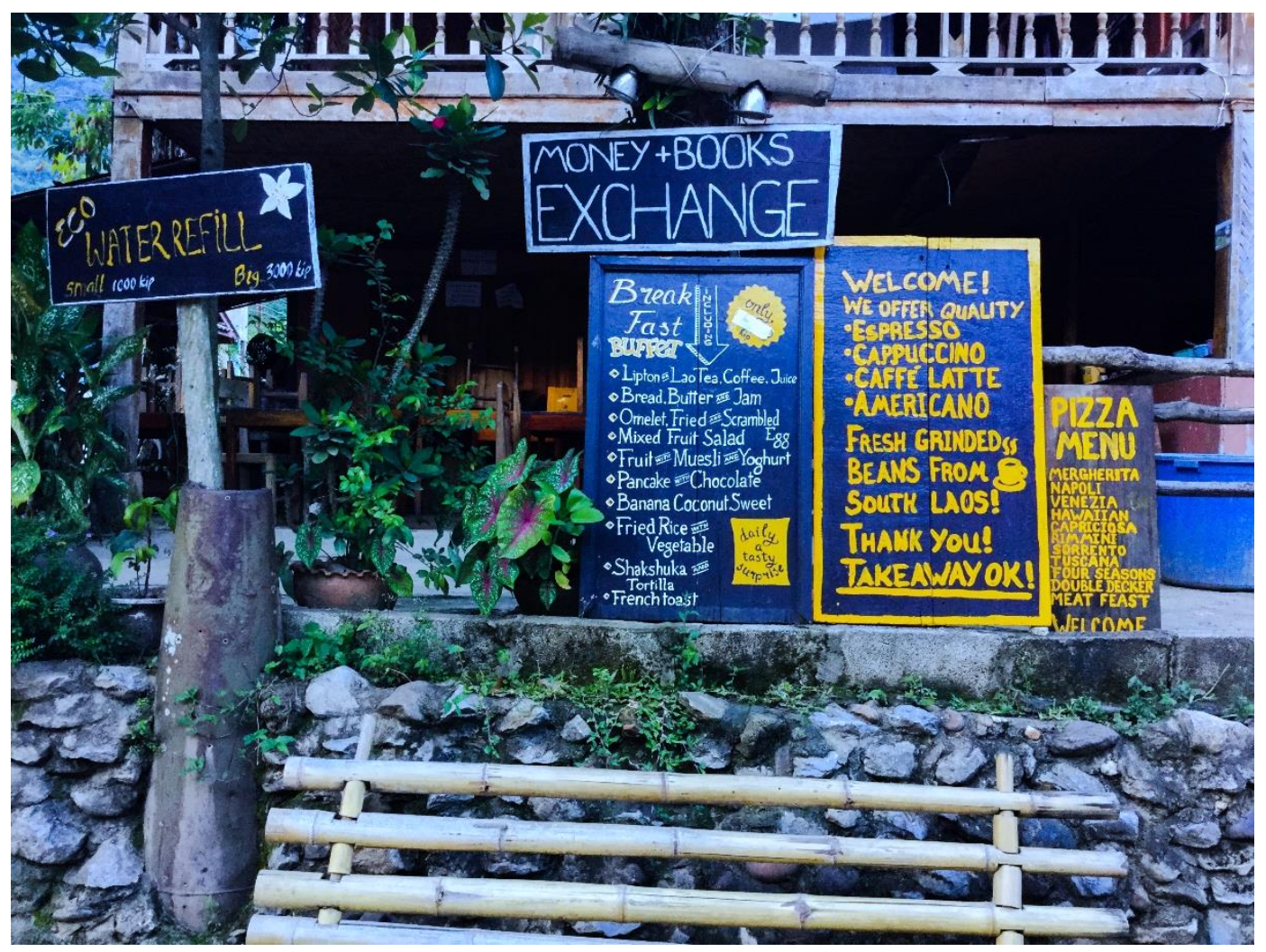

Source: Transect walks (2016)

To further elaborate how tourism has transformed the lives of people in Ban Meuang Ngoy, I will present three personal stories of the people in this village. Guided by a sustainable livelihood analytical framework, I classify the stories into two categories. The story of Ket and two orphan sisters are considered a household unit of analysis, and the story of Duang as an individual unit of analysis.

To begin with, Ket narrated the story as follows:

My husband and I [they divorced around 5-7 years ago] worked very hard in the past 30 years or so. Like other villagers, we also did lowland farming, buying and selling things such as Non-Timber Forest Products [NTFP], salt, gasoline, pigs, chickens, and so forth. And yet we did not earn much to support our family.

After our family started making food for sale, our family life has become much easier [she smiled happily]. Now all of our children graduated from at least vocational schools. Our family's income has also changed from 'low to high.'

We have four children; one boy and three girls. Our daughter, who graduated from Luang Prabang technical and vocational school, 
majored in cooking [about 8 years ago], then opened a restaurant and bar in our village here. She then met a guy from Germany and now they are together in Germany running a catering business. Our son who majored in electrical engineering from the same school is also now living there, helping them run the business.... another daughter is now a teacher teaching at the secondary school in our village (Interview, 10/7/2016).

It can be seen that tourism has had a great impact on Ket's family. Not only has it helped increase the family income, but it has also contributed to their children's education, which in turn, has improved the livelihoods of both generations (parents and children).

The second story was the case of two orphan sisters. Ket described the story as a journey "from the dark to the bright side" (Interview, 10/7/2016). She narrated:

In our village, there are two sisters whose parents passed away when they were young. They used to live together in a small hut. When it was rainy, they both got drenched because the water was leaking from holes on the roof.

When tourism started booming in the village, they started working at the restaurants. They washed dishes and clothes for a living. Sometimes they received tips from tourists.

Now, they have built a new big concrete house from the money they earned, a house with bricks. Without tourism, their life would be hard and I cannot imagine how their life would be, as they are both women and orphans....

The change in living circumstances, from a 'small hut' to a 'brick house', paints a very empowering picture in terms of the economic improvement of the people who live in hard circumstances like the two orphan sisters. Hard work was a characteristic of the two sisters' journey from living in the dark to the bright side, but it also resulted from the emergence of tourism, as noted by Ket.

The third story was the case of Duang, an out of school youth from Ban Meuang Ngoy (Box 5.1). 
Duang, 25 years old, was born and raised in a poor family in Ban Meuang Ngoy. His parents divorced when he was two years old. His mother has special needs, meaning that she could not support her family as much or as easily as she would wish. Duang attended school until grade 3, dropping out in the middle year of schooling, given his low interest in education.

Duang has been interested in taking foreign ( $F$ a laang) visitors to his village for fishing and trekking trips to Hmong and Kmhmu villages nearby. He has now become a local tour guide - not a registered tour guide.

Duang was happy to show me his visitors' recording book where his clients are invited to write feedback, and I read for him too. I was surprised to see how he has impressed his clients from across the world-from France, Demark, Germany, Italy, Australia, New Zealand, and other places.

He told me that whenever he learns to speak English directly from foreigners he really enjoys it (muan jai, he said and smiled happily). No one has taught me or guided me to do that, I did it out of my own preference, he added.

He also told me that although he could not read and write, he is happy as he has achieved his aim - what he wants to do [and perhaps wants to be] in life. He is now building a new house for him and his mother.

Duang also does farm work on a lowland rice farm. When there are no visitors, he goes to the rice field. He also goes fishing, hunting and gathering food. He does whatever he can in order to secure the household livelihood.

Source: Interview, 10/7/2016.

We can see that although Duang lacks literacy and numeracy skills, he managed to achieve his dreams due to the rise of tourism in his village. Duang explained, however, that the lack of such skills limits his ability to serve his clients effectively. In chapter 7, I will explain the extent to which TVET has or has not reached those of marginalised groups like Duang.

By way of concluding, I summarise livelihood activities in Ban Meuang Ngoy as shown in Table 5.2 below. 
Table 5.2 Livelihood activities in Ban Meuang Ngoy

\begin{tabular}{ll}
\hline Type of activity & Activities \\
\hline Farm activity & Lowland rice growing during the rainy season and the dry season, \\
& some upland rice farming during the dry season \\
& Vegetable cultivation on the banks of Nam Ou and Nam Ngoy \\
& Rivers \\
& Cultivation of fruits, eggplants, chili, sesame, and corn; animal \\
& husbandry (buffalo, cattle, pigs, and poultry) \\
Businesses such as quest houses, restaurants, home-based shops, & and pharmacies, etc. \\
activity & Self-employment (local tour guide) \\
& Migration \\
& Driving for tourists (usually by minivan or sometimes motivator) \\
& Weaving for use and for sale (mainly for tourists) \\
Shrimp collecting (on the caves where there are water flows) & Fishing (mainly on Nam Ou River) \\
Voluntary work (participating in community and cultural events, \\
house building, etc.) \\
Teak plantation
\end{tabular}

Sources: Author, based on interviews, transect walks, and observations (2016).

Table 5.2 shows that livelihoods in Ban Meuang Ngoy were diverse, and people had more choices between farm and non-farm activities. Examples of livelihood diversity can be seen in that during the high season for tourists, people can focus on running tourism-related businesses, while during the low season, they can do farm work as well. These multiple livelihood choices may not have been available without the introduction of the New Economic Mechanism.

\subsubsection{Education and migration as new livelihood strategies}

What has been found in this research is that local people in both villages see education and out-migration as a means to secure the livelihoods of their children. Phan, 88 years old, the elder of Ban Huayman, stated that:

Education is the most important thing; it is a key to success. Without education, life is hard.... We will only survive without knowing the meaning of life. [Therefore] it is the devotion of the parents to support their children for better education. As long as their children have stable jobs, parents are happy. We want our children to continue learning, to 
have better lives, not continue doing the hard work like us (Interview, 1/7/2016).

Phan's statement does not only tell how education is viewed as a fundamental instrument for livelihood improvement, but also shows the willingness and aspirations of the parents to invest in their children's education. Kham, also supported to this view. He explained:

The majority of them [people in the village] have fully supported their children for education, and see education as a new way of making a living...As parents [referring to community members, as well as his family] are not educated, they have limited choices to make a living... Nowadays, if we continue doing farming as we use to do, it will not secure our livelihoods. Therefore, our children have chosen education as a foundation for their success in life (Interview, 1/7/2016).

However, when asked: do young people get jobs at home after their graduation? All three participants confirmed that most of their children who studied in the cities (mostly Luang Prabang) continued to live there to find jobs because there are no jobs available at home. The participants further explained that moving to cities helped young people to earn income, with some sending the money back to their families for some basic expenditure needs (improving houses, or paying for health care and their siblings' education).

To some extent, participants viewed that this livelihood change is secured. However, there is a concern regarding the loss of their language (Kmhmu) and culture when youth moved to cities. Kham explained that "when young people move to cities, they marry people of different ethnic groups, then they tend to not speak Kmhmu language, or practise Kmhmu culture” (Interview, 1/7/2016).

In Ban Meuang Ngoy, when asked: What do you want your children to do after their graduation? Where and Why? Khamphui, an elder of the village replied: "Wherever they want as long as they have secure and stable jobs" (Interview, 10/7/2016). Boun, a community member, also stated that: "for my son, I will find him a job in the district headquarters [Nongkhiaw] because there is no job for him in our village" (Interview, 9/7/2016). As such, it can be argued that limited job opportunities are a key factor pushing rural people to move to cities. In chapter 6 , I 
will explore whether out-migration is what youth want to do, or if it is just the desire of their parents.

\subsection{Livelihood challenges}

Key livelihood challenges identified by the local people in the two villages include the decline of natural resources (in the case of Ban Huayman), the impact of hydropower projects on rural tourism (in the case of Ban Meuang Ngoy), and a lack of access to markets (for both villages). Each of these challenges are presented below.

\subsubsection{Decline in natural capital}

Decline in natural capital, or land scarcity, was mentioned by the participants interviewed in Ban Huayman. Kham, a head of a six-person household, reported that:

We [a household] have three small plots of land and we now have six people in our family. Soon, each of them will all have their own families. The three plots of land will never be enough for us to make a living (Interview, 1/7/2016).

Kham's quote suggests that land scarcity is a result of rural population growth, at least in the case of his household. Land use data was not available in this village to help explain this phenomenon. Therefore, using data from village clusters can be useful.

A report by the Department of Agricultural Land Management (DALaM), Ministry of Agriculture and Forestry (MAF) (DALaM, 2010) shows that, in 2010, the availability of agricultural land for total upland rice farming and crop planting per household at the village level, including Ban Huayman, was less than three hectares, and, for upland farming and cropping alone less than two hectares per household (Table 5.3). These figures suggest that land ownership of the local people in Kum-ban Bo is relatively limited. 
Table 5.3 Current land use in Bo Kum-ban (village cluster) in 2010

\begin{tabular}{lrc}
\hline Agricultural land use (hectare) & Bo Kum-ban & Land per household* \\
\hline Upland rice \&other crops & 1,086 & 1.92 \\
Livestock pasture & 351 & 0.62 \\
Lowland rice & 53 & 0.09 \\
Area for fruit production & 21 & 0.04 \\
\hline Total & 1,511 & 2.67 \\
\hline
\end{tabular}

Note: * calculated by the author. Calculation: number of available land area/number of household (565 households in total)

Source: Author, based on data from DALaM (2010).

Factors leading to land scarcity in this village are not clear. Using a study conducted by Rigg (2006) can provide some indications. He states that land scarcity in rural Laos has derived from several factors. At the village level, agricultural land degradation is associated with local people's over-use of land, their use of fertilizer, natural hazards, and rural population growth. At the national level, factors include the development process and policy interventions of the government under the new economic reform, more specifically the introduction and implementation of the Land-Forest Allocation Programme (LFAP). It seems that land squishing is a major concerned not only in the case of Ban Huayman, but many parts of rural Laos.

In the near future, agricultural land allocation for villages under the Bo Kumban, including Huayman village, will be even scarcer. A report from DALaM indicates that a large proportion of agricultural land in this village cluster will be allocated for temporary industrial crops/cash crops (Table 5.4). Upland rice will be dramatically decreased from 1,086 hectares in 2010 to 72 hectares in 2020. This suggests that, if the inhabitants in Ban Huayman continue to practise upland farming, there will be great challenges concerning land scarcity. 
Table 5.4 Projected agricultural land use in Bo Kum-ban (village cluster) by 2020

\begin{tabular}{lrc}
\hline Agricultural land use (hectare) & Bo Kum-ban & $(\%)^{*}$ \\
\hline Temporary industrial crops & 3,219 & 80.11 \\
Natural grass & 351 & 8.74 \\
Animal grazing area & 265 & 6.60 \\
Lowland rice & 101 & 2.51 \\
Upland rice and other crops & 72 & 1.79 \\
Crops during dry season & 10 & 0.25 \\
\hline Total & 4,018 & 100.00 \\
\hline
\end{tabular}

Note: * calculated by the author. Calculation: number of each type of land area/total land areas. Source: Author based on data from DALaM (2010).

\subsubsection{Tourism impact due to hydropower development projects}

In the case of Ban Meuang Ngoy, there was a pressing concern towards the potential impact of a hydropower plant project (Nam Ou 3) on the village's tourism activities. Khamphui, an elder of the village, explained:

The Dam project [Nam Ou 3] may cause a decline in the number of tourists visiting our village. The Dam will block the flow of tourists from Meuang Khua district [Phongsaly province] to our village. To travel to our village, they have to stop over on the Dam site and take their belongings out, then take them to the car and then, again, to another boat from the Dam site to our village. It will never be as easy as traveling as before (Interview, 10/7/2016).

Before discussing further, I will provide the background of the hydropower plants to enhance our understanding about the situation.

Nam (river) $\mathrm{Ou}$ is one of the largest tributaries of Mekong River and there were seven hydropower plants (cascade projects), including Nam Ou3, to be built across the River basin, covering $475 \mathrm{~km}$, from the province of Phongsaly in the north to Luang Prabang in the south (Fig. 5.8) (Vongsay cited in Zhang, 2011). The 'Master Agreement' for Nam Ou Hydropower Project was signed between the government of Laos and SINOHYDRO Corporation Ltd., the Chinese company, in April 2011 (SYNOHYDRO, 2011). The total budget for the project was around 16 trillion kip (US\$2 billion), 85 percent of the budget was funded by the company 
(project developer) in the form of loans, and the remaining 15 percent provided by the government of Laos (Zhang, 2011). After 25 years, the government will take over operation (Kemp, 2013).

As we can see in Fig. 5.8, the Nam Ou 3 cascade project has been built between Ban Meuang Ngoy (Ngoy district) and Meuang Khua district, Phongsaly province. Therefore, as Khamphui explained, the Dam project may block the flow of tourists from Meaung Khua to Meuang Ngoy.

In 2013, a UK-based Magazine, Wetlands, published an article highlighting the potential negative impact of Nam Ou hydropower plants on local tourism in the northern region of Laos, entitled "Death of the riverboats" (Kemp, 2013). According to the author, placing a Dam on banks of Nam Ou is "unsuitable geology” (Kemp, 2013, p. 1). Tourists interviewed by Kemp (2013) explain:

There is a ... great dam being built on the way here ... Travellers aren't gonna come. Today, taking a boat up the [Nam] Ou rates highly on Lao travellers 'must do' list and I saw signs of tourism-fuelled prosperity during my own travels. The riverboats coming upstream from Luang Prabang were crowded with travellers taking photos of us as we passed them going downstream. (Kemp, 2013, p. 1).

The above quote validates the concern raised by Khamphui presented earlier. A recent study, the Cumulative Impact Assessment (CIA), conducted by Meynell (2016) suggests that the hydropower projects have created significant negative impacts on the tourism and livelihood activities of the local people, such as: the loss of agricultural land, reduction in fish catches, increase in the demand and price of fish and Non-Timber Forest Products (NTFPs), and pressure on wildlife. 
Fig. 5.8 Nam Ou 3 hydropower project in Laos (2012)

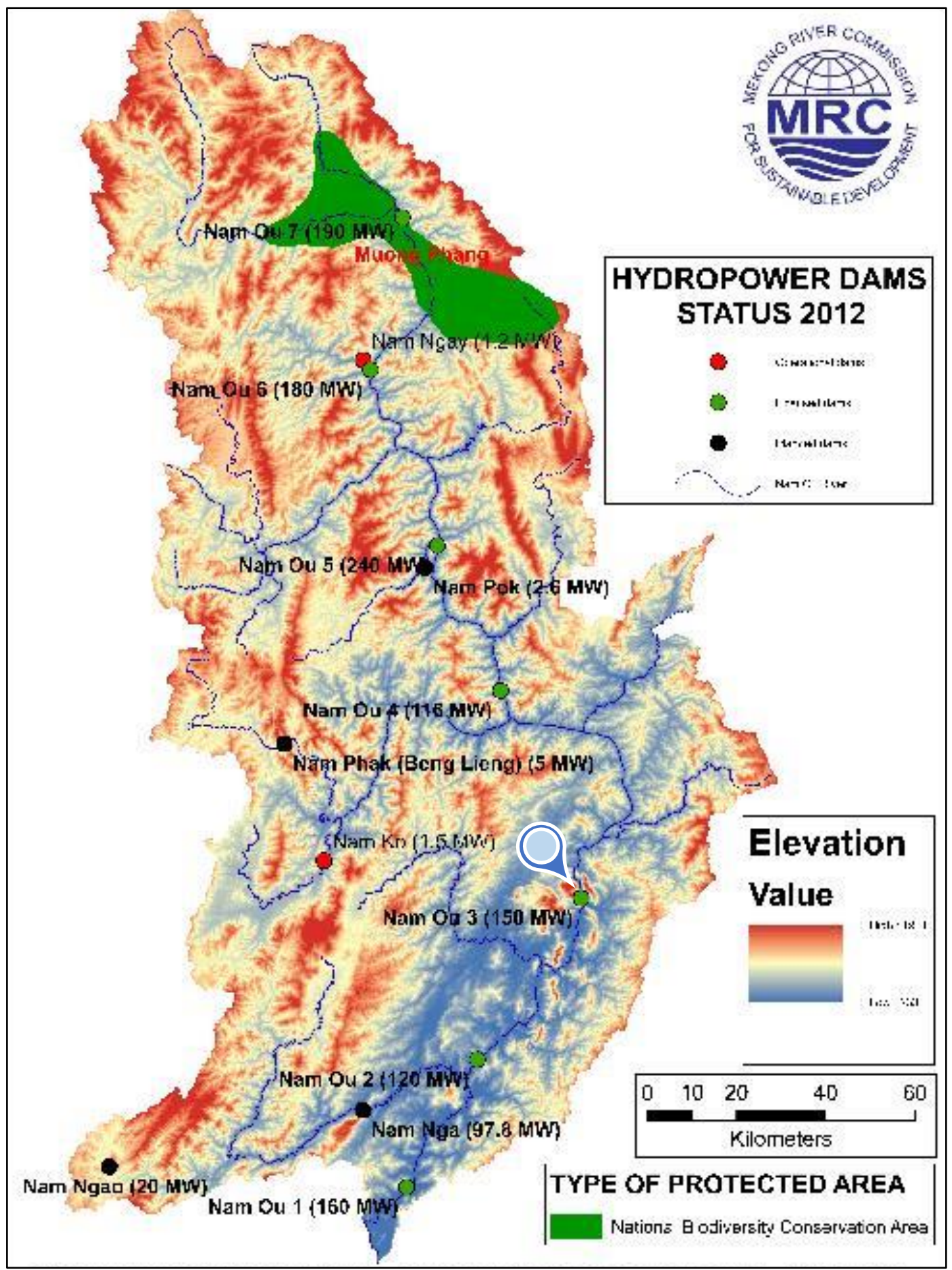

Source: Meynell (2016, p. 8). 


\subsubsection{Limited access to markets}

Lack of access to markets is a major concern brought up by participants in the two study villages. For Ban Huayman, there was no market in the village. People mostly rely on the district market for buying goods. Based on my observations, although the village is only $15 \mathrm{~km}$ away from the district headquarters, agricultural products from this village were virtually absent from the district market. When visiting the market (Fig. 5.9), vendors told me that almost all fruits, meats, fish, vegetables, onions, and garlic were bought from Luang Prabang city vendors, who purchased these products from Thailand. Noticeably, many of these normal goods can be produced by the local people. Importing such ordinary goods is not necessary (Fieldnotes, 2016).

The argument is that the connection between village and district markets is uneven, despite having road access. This raises a question as to whether the economic policy has promoted the rural economy in a way that increases connectivity from village to village, and from villages to district, and between districts within the province, for the exchange of goods. Or, alternatively, if the economic policy has concentrated too much on urbanisation, neglecting the importance of rural development.

Fig. 5.9 Market in Phonxai district

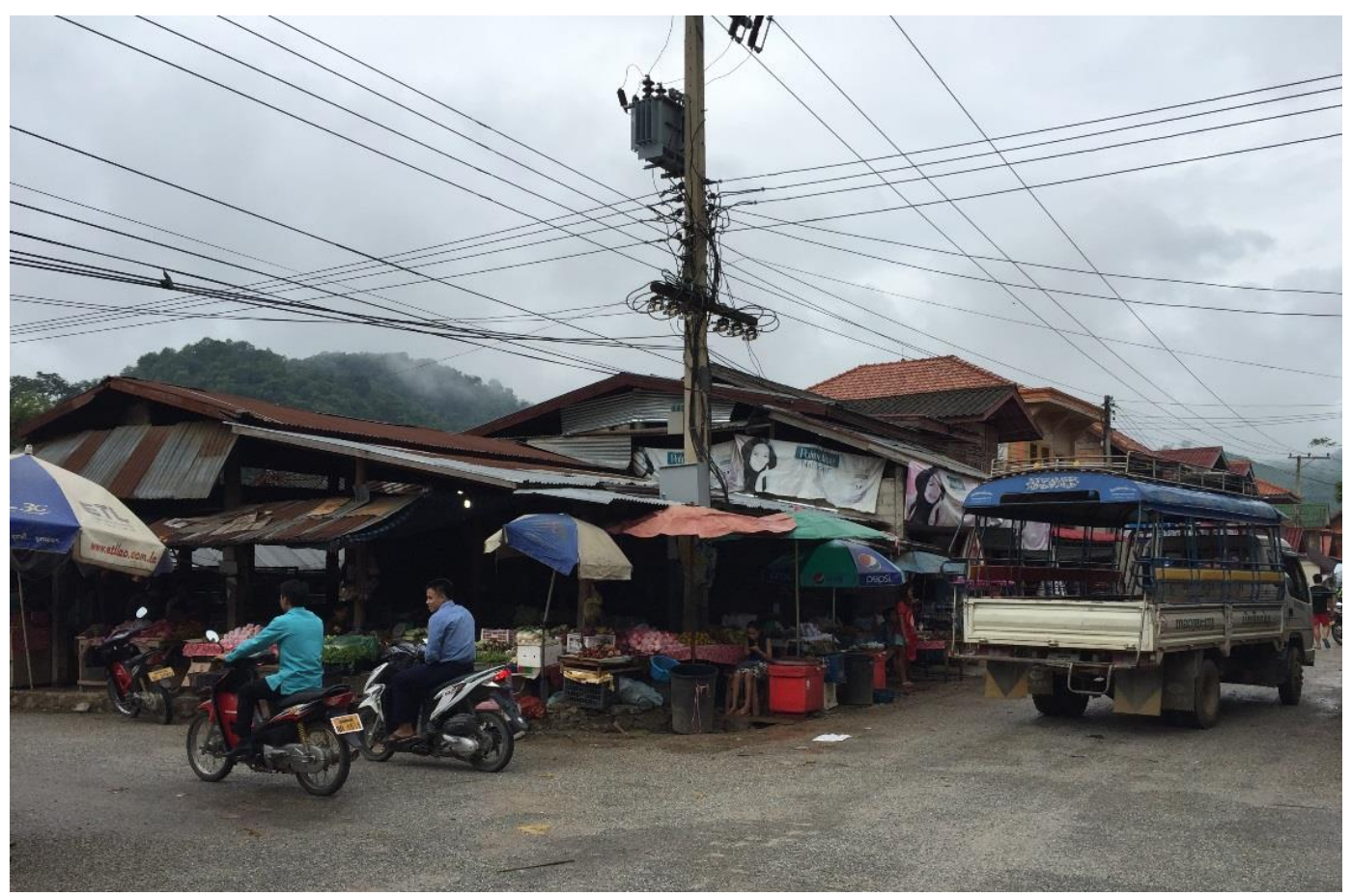

Source: Author (2016). 
In Ban Meuang Ngoy, Mr. Boun, a community member, told me that there was a market fair organised every ten days in their village. However, most of the goods were clothes, not agriculture products (Interview, 9/7/2016). Goods in Ban Meuang Ngoy were exchanged, yet they were mostly exchanged within the village and primarily among tourists. He stated that:

It is hard for us to find a market, as the village is located in the farthest area of Ngoy district. Fruit and vegetables cannot be sold as much; sometimes we have a surplus. Worst, agriculture products are never purchased at a fair price... We find access to markets challenging (Interview, 9/7/2016).

As the village is isolated from the Meuang Ngoy district, I can see the challenge of market access for Ban Meuang Ngoy villagers. Ban Meuang Ngoy had a small marketplace where people sell things mainly in the evenings (Fig. 5.10). The market was not properly arranged. It was a public space where everyone can set up their own place and sell food.

\section{Fig. 5.10 Market in Ban Meuang Ngoy}

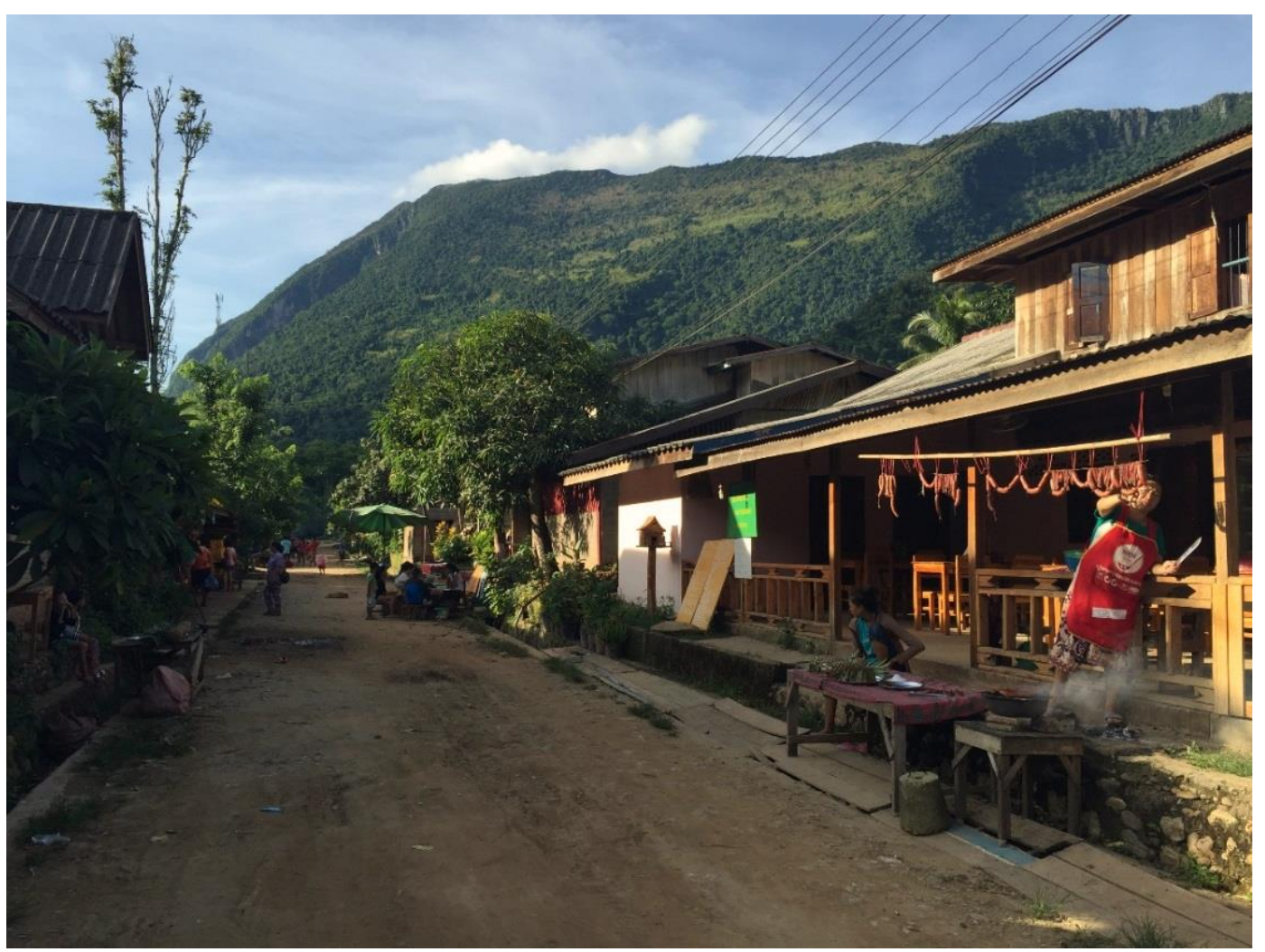

Source: Author (2016) 
What was sold in the village market had sometimes been purchased from the Nongkhiaw district market. At the district market, I observed that local people purchased and exchanged quite a variety of agricultural products. When visiting the 'Morning Market' of Ngoy district (Fig. 5.11), the market was very crowded and many of the agricultural products displayed were grown by local people, some of whom reside approximately $6 \mathrm{~km}$ from the district centre (personal communication, 7/7/2016). Forest products, such as mushroom and bamboo shoots, were also available in the market. Meeting demand for the district market, however, does not seem to require products supplied from rural villages like Ban Meuang Ngoy. Again, market connectivity is limited, thus the ability to expand markets in rural areas is likely to be impossible. The lack of market access in these two villages draws attention to the reform of the market-oriented economic policy.

Fig. 5.11 Morning market in Meuang Ngoy district

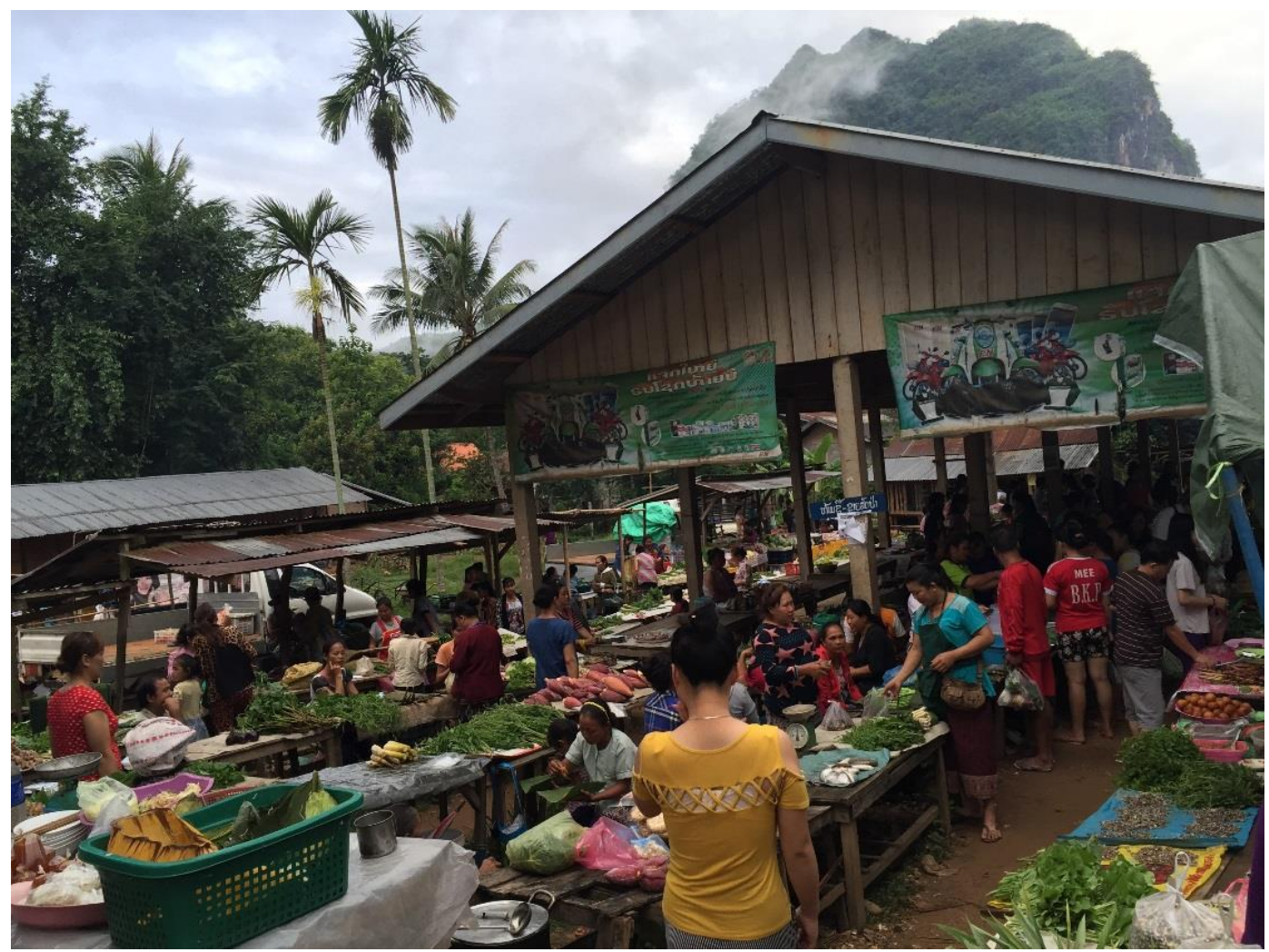

Source: Author (2016).

Before summarising this chapter, it is worth presenting key discussion points in a more segregated and comprehensive way. Based on the livelihood framework presented in chapter 2, Table 5.5 below presents findings in this chapter by organising them as a process of change. It divides the contents into four Columns. 
Column (a) contains livelihood activities of the two villages; Column (b) contains key government policies that influence livelihood activities and change; Column (c) contains livelihood strategies, resulting from the policy interventions; and Column (d) contains livelihood challenges facing people in the two villages.

Table 5.5 Summary of livelihood activities in two visited villages

\begin{tabular}{|c|c|c|c|}
\hline $\begin{array}{l}\text { Livelihoods } \\
\text { activities }\end{array}$ & $\begin{array}{l}\text { Transforming } \\
\text { structure and } \\
\text { process } \\
\text { (b) }\end{array}$ & $\begin{array}{l}\text { Livelihood } \\
\text { strategies }\end{array}$ & $\begin{array}{l}\text { Livelihood } \\
\text { emerging } \\
\text { challenges } \\
\text { (d) }\end{array}$ \\
\hline $\begin{array}{l}\text { Farm } \\
\text { Subsistence } \\
\text { agriculture: upland } \\
\text { farming, some } \\
\text { lowland farming, } \\
\text { non-cash crops } \\
\text { production, and } \\
\text { self-sufficient } \\
\text { livestock rearing }\end{array}$ & $\begin{array}{l}\text { Introduction of } \\
\text { programme on } \\
\text { eliminating shifting } \\
\text { cultivation and } \\
\text { promoting } \\
\text { agricultural } \\
\text { stabilization } \\
\text { Introduction of NEM } \\
\text { (change from } \\
\text { subsistence to } \\
\text { market demands) }\end{array}$ & $\begin{array}{l}\text { Livelihood } \\
\text { diversification } \\
\text { Tourism as a } \\
\text { livelihood strategy } \\
\text { Education and rural- } \\
\text { urban migration }\end{array}$ & $\begin{array}{l}\text { Agricultural land } \\
\text { scarcity due to } \\
\text { rural population } \\
\text { growth, and land } \\
\text { degradation } \\
\text { Limited financial } \\
\text { capital and market } \\
\text { access within and } \\
\text { between local and } \\
\text { sub-national level } \\
\text { Potential long-term } \\
\text { negative impact of } \\
\text { hydropower plants } \\
\text { on ecotourism } \\
\text { Destruction of } \\
\text { sources of protein } \\
\text { (fishing) }\end{array}$ \\
\hline
\end{tabular}

Note: $\rightarrow$ = leading to...

We can see that, as shown in Table 5.5, in addition to villages' historical, social and cultural backgrounds, the government's policy interventions have influenced significantly the way in which rural livelihoods in the two visited villages are arranged. The shift of livelihoods depends very much on the capabilities of local people, as well as the natural resources available. Local people in Ban Meuang Ngoy, for example, who have a long historical background, adapted to change when tourism rose in the village. Being resource-abundant has also enabled them to grasp the opportunity. This differs from Ban Huayman, where people have only settled since the 1960s, and where resources are limited (mainly only upland areas). Thus, they seemed to have less capabilities and fewer livelihood options 
when compared to local people in Ban Meuang Ngoy. Moreover, their culture has limited their capacity to adapt to livelihood change, from subsistence farming to meeting market demands. Resistance to such change occurs because the marketoriented approach does not seem to fit well into their culture. The tension between "embracing change" vs. "resistance to change" raises a question over policy development in Laos: Should policy focus on the needs of locals, or should it continue forcing local people to change for the sake of policy requirements?

Among others, two key livelihood challenges appeared in the two study villages. One is the concern for the impact of development projects (e.g., hydropower pants). This suggests that a carefully considered project development plan and management must be in place, if rural livelihood systems are to be secured and sustained. Another is the concern of limited financial capital and market access among rural people. This is a sign of policy failure in that while it encourages people's access to market and the exchange of goods, it cannot establish a business environment for them.

\subsection{Summary}

To conclude, the way in which the local people, in the two case study villages of Luang Prabang, arrange their livelihoods is based primarily on their culture and capabilities, as well as the availability of natural resources, and economic resource and opportunities. While some local people embrace livelihood change from farmto non-farm-based activities, others remain working in the shifting cultivation system. Their livelihood arrangement has been influenced significantly by the historical, cultural, and economic backgrounds of the village, as well as the introduction of the market-oriented policy. The research also reveals that shifting cultivation has been historically and culturally embedded in the lives of the Indigenous peoples for several decades. Hence, they resist change. This suggests that, to fully support rural livelihoods, the government may consider alternatives to the current development policy, such as a holistic approach.

The research also found that rural people have experienced several livelihood challenges, partly due to the government's development interventions and international development projects, as well as limited access to market and the decline of natural resources (agricultural land). Attending higher education and 
migrating to cities are, therefore, seen as new livelihood strategies for many rural households, especially youth from impoverished families. The next chapter expands on this by exploring the perceptions and aspirations of rural youth from these two villages and other provinces of the northern region of Laos. 


\section{Chapter 6}

\section{Rural youth and TVET: \\ Aspirations, influences and limitations}

\subsection{Introduction}

In chapter 5, I explained that education and out-migration are seen as new livelihood strategies for many rural households in the study villages. This chapter expands on these issues by exploring the livelihood aspirations held by youths. The chapter attempts to provide answers to the second sub-question of this research. 'What are the livelihood aspirations of youths from rural villages in Luang Prabang province, and what influences their aspirations?'

The perspectives of youths from two TVET colleges and Souphanouvong University in Luang Prabang are included in the discussion. Also, the chapter includes voices from institutions and entities that are directly linked to youth education and development such as families, schools, the government, and external development agencies. Studies from elsewhere related to youth aspiration are also included.

Instead of describing what rural youth aspire to for their livelihoods, the chapter examines the reasons behind such aspirations by investigating how they perceive education, especially TVET, and how they make their educational choices. Factors that influence their decision-making and aspirations are also examined. Results show that education is seen as an important element to help youth achieve their dreams. However, social, cultural and economic factors have limited the education opportunities for many rural youth in Luang Prabang, as well as those from the northern region of Laos.

Before discussing what factors, specifically, influence the decision-making of youth in respect of education choices and aspirations, the chapter firstly presents people's overall perceptions about TVET in Laos. 


\subsection{People's perceptions on TVET}

This section explores people's perceptions on TVET in Laos. These include the perceptions of youth who currently attend TVET in Luang Prabang province, local people in the two study villages, employers, and society as a whole. Each group is examined separately as follows.

\subsubsection{Youth perceptions}

Among youths who attend Luang Prabang TVET, TVET was regarded as attractive and practical rather than theoretical, and relevant to the needs of the labour market. They also believed that studying at TVET was more flexible than at university as they could do part-time jobs while studying. Taking part-time jobs was seen as critical for some of the students from low-income families. This allows them to earn additional income to support their own education without relying much on family support. An example can be seen from a quote of Vattana, a second year male Kmhmu ethnic student of LBP-TVET, taking a furniture-making programme:

Studying in VET is more practical than at university. For instance, students learn about theoretical concepts for a week at school and for another week they practice at the company. As our college emphasises practicality, students who graduate from here are competent in their fields of study... with the knowledge I have obtained, I hope to have a good future career after my studies (Interview, 25/6/2016).

Vattana was a former architecture student at Souphanouvong University, but he dropped out due to insufficient financial support from his parents. When he moved to LPB-TVET, he found a part-time job, to which he was introduced by his teachers (Interview, 25/6/2015). He explained that his academic and social life has improved since studying at the university, since the lower workload in TVET allowed him the extra time for his part-time job and for socializing with friends. Through working part-time, he can earn sufficient income for his study without having to ask for support from his parents.

Another example is from Chaiphone, a third-year female Lao ethnic student taking a hospitality programme. She stated: "I have found that what I chose [cooking] is relevant to the labour market needs as there are many jobs available within the hotel industry and similar businesses that I can work in" (Interview, 
22/6/2016). Davone, a first-year civil engineering female Lao ethnic student, said: "After studying here for a while, I feel like it is actually good to study at TVET as it helps me to realise what I can do after my graduation" (Interview, 22/6/2016). She expected to work with development projects (e.g., NGOs), she explained further.

The shared experiences of Vattana, Chaiphone, and Davone suggest that TVET is suitable for those who are interested in acquiring practical knowledge and skills that are relevant to the demands of the labour market. TVET is also seen as an alternative to university education where tuition fees and other expenses may be too high for students from poor family backgrounds to afford, as commented by Vattana. Perhaps because of the practicality of TVET, Davone has realised what she wants to do in the future quite quickly, despite studying for less than a year.

It can be seen that, for the youth interviewed in this research, TVET was considered a feasible option for students for its practicality, flexibility and low cost. The students interviewed also showed their desire to match their study with the need of labour markets. Since TVET can help young people achieve their career goals in a shorter time in comparison to higher education, it is likely becoming the popular choice for youth in rural Laos.

An educator, the director of LPB-TVET College, held a similar view and argued that youth have a positive view towards TVET institutions as the skills TVET offer are practical and in demand by employers. He explained:

In the past two years, many students have chosen to study at university. After their graduation, however, few of them have found jobs. Most of them are unemployed. Therefore, some university graduates enrol in TVET. Youth are aware that studying at TVET can lead them to employment (Interview, 216/2016).

Both the director and a teacher of LPB-TVET College insisted that the college's Social Marketing Campaign (SMC) has enabled youth, including those living in remote areas, to understand the advantages of studying in TVET institutions, such as having more job opportunities than studying in university would provide (Interview, 21/6/2016). A director of NAFC commented that "student enrolment [in NAFC] is also in surplus, mainly due to the SMC" (Interview, 10/6/2016). According to a tracer study conducted by Schroeter (2015), 
students carried a positive view towards NAFC - the college has a high reputation, leading to good employment, and improving income (self-employment).

\subsubsection{Community perceptions}

Even though TVET is highly preferable for youth in the rural context, it was not in favour and supported by the majority of community members interviewed in the two studied villages. All of them wished for their children to obtain university education, rather than attending TVET. The village head of Ban Huayman, for example, strongly argues that:

The reason why many people prefer to send their children to university is because organisations, both in private and public sectors, recruit only university graduates... TVET is also chosen when children cannot get into university (Interview, 1/7/2016).

The above statement suggests that TVET qualifications are not well recognised by employers, in either private firms or public sectors. Therefore, TVET is considered a secondary choice of education among parents and students. During my fieldwork, I was unable to interview employers. However, it is worth presenting findings from some in-country studies elsewhere to compare and contrast the perceptions of youth and community.

\subsubsection{Employer perceptions}

Schroeter (2015, p. 43), in her tracer study of 31 employers in the seven of provinces in the north and three provinces in the central region of Laos, revealed that "employers are, in general, quite satisfied with the graduates employed from NAFC," partly because of the 'practical skills' and 'hardworking' attitudes of graduates, resulting from the college's orientation of the 'practice-oriented' and 'student-centred teaching' approaches.

A large scale in-country study conducted by the World Bank (2013, p. 77) reported that "employers... are not satisfied with the skills being produced by the higher and vocational education system." The private firms commented that "the Lao education system does not create the right skills" for them. These studies confirm that the issue is about 'skills inadequacy,' rather than 'skills recognition' 
as perceived by community members. Perhaps, community members have a lack of access to up-to-date information about skills needed by private firms.

There is also an interesting trend in terms of employment in Laos. The majority of people wanted to work for the government; only a few wanted to work for private firms, or to start up a business. Three staff members of the Career Counselling Unit (CCU) at NAFC explained:

We used to conduct an assessment with students in our college. We found that almost 90 percent of them wanted to work for the government. Only 4 to 5 percent wanted to work in the private sector and other 4 to 5 percent wanted to start up a business. When asked why, they replied that they are afraid of taking high risks in doing business. They also said that they dislike the nature of work in the private sector - it is uncertain. Working for the government is more secure and certain (Interview, 10/6/2016).

However, the author reported that although all employers appreciate the practical focus of education offered by NAFC, some employers, especially public institutions, prefer hiring graduates with bachelor degrees. Therefore, there is a tendency that, as Schroeter (2015, p. 44) commented, "graduates from NAFC and other agricultural colleges will be left out and not considered-despite their competence."

Laos is facing a great challenge - not only does it have to solve the problem of a skills mismatch between education and labour markets, it also has to address the issue of employment flows to a particular type of institution. All government officials consulted in this study (educators at the school and an education planner in the central ministry) reported that the government is currently encouraging students and graduates to find work from the private sector by establishing job fairs and providing career counselling (Interview, 10/6/2016; 9/8/2016).

\subsubsection{Societal perceptions}

There is a collective perception shared by some participants based on their experiences and observations. Mr. Somphone, an experienced education worker from the World Bank ${ }^{11}$, strongly asserted that:

\footnotetext{
${ }^{11}$ Note that his view expressed here does not necessarily reflect that of the World Bank.
} 
TVET is unpopular among people in Lao society in general as recruitment criteria in Laos are based mainly on the level of education, rather than the level of competency and capability of the applicants. Therefore, the majority of people opt for university, instead of vocational education, so that they can hold better positions in the workplace and earn more (Interview, 11/8/2016).

The government of Laos is aware of this phenomenon. A high-ranking government official in TVED (MOES) provided a long statement, but worth citing as follows:

The overall reputation of VET in Laos is low as the people have not accessed TVET information [locations and the offer of TVET], as well as labour market information systems ${ }^{12}$ [skills required by private firms]. Therefore, they could not make the right decisions.

People, especially in urban areas, perceive TVET-related jobs as "difficult, dirty, and dangerous (3Ds)" Hence, they do not like it. They prefer white collar work (office work) than blue collar (manual labour).

People who live in remote and isolated areas do not know what TVET is, as there is no TVET-related information available for them and TVET institutions are mostly established in the city and in the central areas of provinces (Interview, 9/8/2016).

The above statement suggests that not only people perceive TVET to have a low reputation, but also the skills it offers favour some particular groups of society. This contradicts how rural youth perceive TVET, as explained earlier.

From the different views of community members, an education specialist, and a government official presented above, we can see that there were at least three reasons why TVET was considered unattractive: low level of recognition, low reputation of TVET since TVET jobs are viewed as difficult, dirty, and dangerous (3Ds), and a lack of information about TVET in terms of its location and courses offered. These are the remaining challenges in TVET development and promotion in Laos. I will discuss this issue more detail in chapter 7.

\footnotetext{
${ }^{12}$ The system may include websites, social media sites, or radio broadcasting programmes that particularly disseminate labour market needs such as types of jobs, qualifications, and specialised areas that are required by employers.
} 
How people perceive education may affect the decisions they make. Their decision-making can also be influenced by several factors. Section 6.3 below explores how rural youth make their choice of education and what influences that decision-making.

\subsection{Youth decision-making and influencing factors}

\subsubsection{Decision-making}

Youth decision-making on fields of study towards educational pathways involves several factors: the interest and passions of individuals and their family, educational institutions, and social networks. All of the youth interviewed reported that they had the freedom to choose their course of studies, whereas their parents, relatives, and friends provided overall guidance and suggestions. Table 6.1 below gives examples of how and why youth made their decisions on educational pathways.

Table 6.1 Youth educational decision-making

\begin{tabular}{|c|c|}
\hline $\begin{array}{l}\text { Individuals/ } \\
\text { Institutions }\end{array}$ & Statements of individual youth \\
\hline $\begin{array}{l}\text { Ms. Chaiphone, } \\
\text { Lao, LPB-TVET }\end{array}$ & $\begin{array}{l}\text { I chose my field of study based on my preference and the advice } \\
\text { of my relatives. My aunt runs a restaurant business and she } \\
\text { expects that I can help her manage the business after my } \\
\text { graduation. }\end{array}$ \\
\hline $\begin{array}{l}\text { Ms. Davone, Lao, } \\
\text { LPB-TVET }\end{array}$ & $\begin{array}{l}\text { My father is a civil engineer in the village. I chose a civil } \\
\text { engineering programme and my parents like it too. I think what } \\
\text { my father does influences my choice as well. }\end{array}$ \\
\hline $\begin{array}{l}\text { Mr. Vattana, } \\
\text { Kmhmu, LPB- } \\
\text { TVET }\end{array}$ & $\begin{array}{l}\text { My parents only give me overall direction on education matters. } \\
\text { Final decision-making depends on myself and I chose what I } \\
\text { like. }\end{array}$ \\
\hline $\begin{array}{l}\text { Ms. Sida, Kmhmu, } \\
\text { SU }\end{array}$ & $\begin{array}{l}\text { At first, I did not know what courses are offered at this } \\
\text { university. I have senior friends who were studying here, they } \\
\text { told me about it. I chose this course [tourism] as there are many } \\
\text { tourism-related activities in the district I come from [Ngoy } \\
\text { district]. }\end{array}$ \\
\hline $\begin{array}{l}\text { Ms. Kao Mua, } \\
\text { Hmong, SU }\end{array}$ & $\begin{array}{l}\text { I made my own decision. I asked my parents and the people in } \\
\text { my village, they did not know about the fields of studies. I } \\
\text { chose this field because it is newly offered by the university so } \\
\text { there might be more jobs available for me in the future. }\end{array}$ \\
\hline $\begin{array}{l}\text { Mr. Somchai, } \\
\text { Kmhmu, SU }\end{array}$ & $\begin{array}{l}\text { I chose my journey of education with my own passion. My } \\
\text { mother did not want me to continue as there is no one helping } \\
\text { her with the work at home. Yet I decided to study until I } \\
\text { finished high school and then now at university. }\end{array}$ \\
\hline
\end{tabular}

Note. SU = Souphanouvong University; LPB-TVET = Luang Prabang TVET

Sources: Interviews (June, 2016). 
It can be seen that the decision-making process of youth is collective and that the influence from family and social networks seem to play a vital role too. Some students seemed to be influenced by their family members to some extent, while in other cases they made their own choices. The decision-making direction was often based on family professional history, or simply personal preference for fields that were believed to hold potential for job opportunities in the future.

An example can be seen from the case of Ms. Chaiphone, who has an aunt supporting her education and expecting to have her help run the business after she graduated. Similarly, Sida received suggestions from her friends that helped her make a better decision in terms of what is offered in school, and what job prospects she could expect in her district. However, Ms. Kao Mua, who has no supporting network for her decision-making, seems to face some difficulties through the process, although she can still make it. Crucially, Kao Mua might be in the position of choosing what she wants, despite being influenced by others. I observed that, during the interviews, all these participants were very confident women, and they seemed to be proud of what decisions they made. While Vattana made his decision based on the overall guidance of his parents, Somchai was almost in the position of making decisions on his own; as he firmly stated, "I chose my journey of education with my own passion". More of Somchai's story is discussed in section 6.4.

Local people's comments were consistent with what youth explained. Three parents, two elders, and a village head in the two study villages told me that they were only involved in giving overall advice to their children's educational decisions (Interview, Jul, 2016). They gave space for their children to make their own decisions - what they wanted to study and where they wanted to work. Ket, a woman in Ban Meuang Ngoy, explained:

I leave the decision to my children on what they want to study. My daughter chose a cooking programme at LPB-TVET, I also like it... My second daughter chose Teacher Education [at Souphanouvong University]. I also like it as I used to be a teacher and I wanted her to follow my path too. My son chose electrical engineering [at LBPTVET], this was what his father wanted (Interview, 10/7/2016).

Besides the family setting, this research found that educators provided some level of support in helping students make their decision towards educational 
choices. A secondary school teacher in Phonxai district told me that he, as well as other teachers in his school, also provided advice to students in addition to the guidance provided by their parents. He stated:

There are three things that we tell our students to be aware of: the direction of socio-economic development of the country, the future development plans of the province, and the development potential of the district and village where students live. This is to help them understand their employment prospects. The parents of students, especially in remote areas, do not understand these factors, but we help students in their decision-making (Interview, 4/7/2016).

From community members' viewpoint, relatives also played a significant role in providing information and influencing the choice of education for youth. Two parents of students in Ban Meuang Ngoy told me that they sought advice from their relatives at the Souphanouvong University regarding the courses and quota available before sending their children to study. The types of work common in individual families/kin sometimes influenced views about what youth should be studying as well, because there was a hope that family/kin would help students find work with them after their graduations. For example, in Chaiphone's case, shown in Table 6.1, she will start working with her aunt after her graduation (Interview, 22/6/2016).

\subsubsection{Inhibiting factors}

A government official and three development workers who have been involved in the education development sector explained that there are some critical challenges that affect youth decision-making and aspirations. The latter will be discussed separately in section 6.4. Two key factors that inhibit youth decision-making are social-cultural norms and household economic deprivation.

\subsubsection{Social-cultural factors}

In addition to the pressure of making education choices, youth in rural Laos seem to face severe social-cultural norms that impede them from schooling and realising their aspirations. As Somphone, an education specialist interviewed for this research, explained: 
In Lao society, children have never been taught to be brave, to be excellent, and to be independent in several aspects of lives. Rather, they are taught to listen to adults and follow whatever the adults do. They have also never been taught to seek their own potential and follow their aspirations. Rather, they have been discouraged by the people around them. There is a saying in Lao language: 'It is not necessary for an individual to aim high, as all the high positions have already been taken by the elite, the more powerful people. There is no position available for you.' That is what we should not promote [in Lao society]. Until now, I have not seen any particular project or activity related to boosting the aspirations of young people (Interview, 11/8/2016).

The above quote suggests two issues: (i) school has failed to prepare children to achieve their potential and aspirations; and (ii) social and cultural norms in Lao society have discouraged children and young people from following their dreams. These, from the view of an education specialist, are remaining challenges that require attention from various institutions.

Supporting the education specialist's argument, a high-ranking government official at the MOES asserts that cultural norms in the family setting are a key factor that hinder youth aspiration. He stated:

Traditional practices and cultural norms play a significant role in influencing young people's educational aspirations. Many parents, especially in remote and isolated areas, believe that doing farming is the only way, or a better way, of making a living. They consider that if sending their children to school, no one will help them do the farm work. Girls, especially, are encouraged to stay home and do housework. These are barriers to development that should be addressed urgently (Interview, 9/8/2016).

The government official has highlighted that girls have missed their education opportunities as a result of social and cultural norms which are seen as barriers to education development, and more broadly to socio-economic and human development. This exemplifies that social injustice, inequality, and inequity of rights to education, are a factor in many poor communities in the Lao PDR. A study conducted by Faming (2007, p. 173) found that "girls were brought up simply to be good housewives." This finding confirms the assertion of the government official presented above. 
The government official moved on and explained that:

Regarding education among ethnic groups, nowadays, many Hmong people [Hmong-lu-Mein ethnic groups] have access to education, but only a few among Kmhmu people [Mon-Khmer ethnic groups] have the same access. This is due to their community. If local people in their community value the significance of education or have obtained a high level of education, they are likely to support their children into schooling - not only vocational education, but also higher education (Interview, 9/8/2016).

The inequality of education access suggests that the community plays a fundamental role in promoting children to education. In other words, if parents value education and they are literate, they are more likely to teach their children and influence their children to foresee their future in light of education.

In supporting the argument that girls' education faces significant challenges, two TVET experts (from a bilateral agency working with youth in the northern and southern regions of Laos) argue that:

Women, in particular, are not treated as they should be. They do not have as many opportunities as men do. There is a belief that, in some ethnic groups, the man is the head of the family. Women are thus not encouraged to study or live in the cities. For example, we train women and find work for them in the cities, but when they are not successful and return home, they are blamed by the people in their villages. This social pressure discourages women to go out of their villages in search of opportunities. As we know, there is a saying that "You are a woman, you don't need to study. You just get married” (Interview, 1/8/2016).

From a human rights and social justice perspective, this social discrimination against women is unacceptable. These women should be put in the highest priority of development in Laos. It is a cross-cutting issue that will not be solved, if left to education alone.

\subsubsection{Socio-economic factors}

Household deprivation seemed to be an obvious factor inhibiting youth from education, particularly after secondary school. Mr. Khamphui, an elder in Ban Meuang Ngoy, shared that: 
For each youth to continue his/her education, depends on the household's financial capacity. Nowadays, all we need for education is money_from paying the rent to the tuition fee... As parents in rural villages work on the farm (het hai, het naa) with very low to low income, they cannot afford higher education for their children in the city. Hence, very few of the youth in rural areas continue their studies. This is a huge challenge... Sometimes, a household has to sell two to three buffalos to support their children's education, yet it is never enough.... For those who have relatives, or siblings in the city, their relatives can partially help provide them with support until graduating (Interview, 10/7/2016).

Those rural youth that Khamphui was referring to were those who live in villages surrounding Ngoy Kum-ban (village cluster). His quote suggests that postsecondary education was unaffordable for many poor households in these villages. Some poor households hardly make enough to support their children's education. Although relatives and siblings may be able to partially share the financial burden with parents, this could never be assured in every case. Moreover, those who do not have relatives, or social capital like some other people do, may miss education opportunities for the rest of their lives.

The connection between household economic poverty and school dropout rates was also explained by Ms. Sida, a university student at Souphanouvong University from Ban Meuang Ngoy. She took the case of her friends to illustrate how difficult it was for them to make their journey to educational pathways. She narrated:

It is because of insufficient financial support that young people in our village do not know what to do after completing secondary education. Attending higher education requires a massive amount of money but their parents are poor. Thus, they are discouraged to do so. Ultimately, they drop out... Their decision-making was difficult (Interview, 17/6/2016).

Sida's quote does not only provide us with information on how household deprivation inhibits young people from schooling, but also shows the hard time students have negotiating between what they want to do (aspirations) and the means (finance) to support their dreams. 


\subsection{Youth livelihood aspirations}

Previous sections have discussed how rural youth make their educational choices and the factors that influence those choices. This section, in turn, investigates youth livelihood aspirations. Voices from 16 young people were included in this discussion. These are 6 people from one-to-one interviews (three students from LBP-TVET and three students from Souphanouvong University), and 10 students from LBP-TVET who participated in the focus group activity I conducted. These students undertook programmes/courses within industry and service sectors. To help us understand the aspirations of youth from other sectors, I include the views of 4 students from Northern Agriculture and Forestry College. This source is extracted from SDC (2016)'s online publication entitled: “Student Dreams and Aspirations in Agriculture and Forestry Education - Lao PDR." These students come from Luang Prabang, Xayabouly, Oudomxay, and Huaphan provinces in northern Laos.

To begin with, the aspirations of this group are diverse. Such diversity seems to be influenced by, partly, the TVET institutions (courses that each of the students undertake), their gender and ethnicity. I will present the information based on these themes. Table 6.2 below are examples of youth aspirations from Luang Prabang TVET.

Table 6.2 Aspirations of youth from Luang Prabang TVET

\begin{tabular}{|c|c|}
\hline Individuals & Examples \\
\hline $\begin{array}{l}\text { Ms. Chaiphone, } \\
\text { Lao ethnic } \\
\text { group }\end{array}$ & $\begin{array}{l}\text { I want to live and work in the city as it is convenient and more } \\
\text { modern than our village. } \\
\text { Living and working in the city will help improve my abilities so } \\
\text { when returning home [later in life], I can develop our village to be } \\
\text { modern, as in the city. }\end{array}$ \\
\hline $\begin{array}{l}\text { Ms. Davone, } \\
\text { Lao, ethnic } \\
\text { group }\end{array}$ & $\begin{array}{l}\text { I want to pursue higher education. After that, I want to work with a } \\
\text { development project as it seems to lead me to the bright side of } \\
\text { life. }\end{array}$ \\
\hline $\begin{array}{l}\text { Mr. Vattana, } \\
\text { Kmhmu ethnic } \\
\text { group }\end{array}$ & $\begin{array}{l}\text { I want to become an entrepreneur and run a furniture-making } \\
\text { business. But I may work in the army after my graduation, if I don't } \\
\text { have other opportunities [i.e. if he did not achieve the first aim]. }\end{array}$ \\
\hline
\end{tabular}

Sources: Interviews (June, 2016).

Chaiphone lives in Nan district, only around two to three hours' drive from Luang Prabang city. However, she wished to migrate to the city where it is more 
convenient and modern. Later in life, however, she wanted to return home and help develop her community. While Davone wanted to pursue higher education, Vattana planned to go into business based on the skills he gained from the school. There is almost no difference between the aspirations of male and female youth from this college. However, Davone explained to me that it was unusual for women to study civil engineering and she experienced being discriminated against, in the first place because of her study choice (Interview, 22/6/2016). It can be assumed that her aspiration was high enough to allow her to overcome such barriers. Otherwise, she could have changed to another course - the service sector that is popular among other female youth, as explained in chapter 4 (section 4.6.2).

There was a clear distinction between the aspirations of youth attending LPBTVET and those attending university. While youth from TVET mostly aspired to work in the private sector or run small start-up businesses, youth from university seemed to look forward to working in the public sector (Table 6.3).

Table 6.3 Aspirations of youth from Souphanouvong University

\begin{tabular}{|c|c|}
\hline Individuals & Examples \\
\hline $\begin{array}{l}\text { Sida, Female, } \\
\text { Kmhmu ethnic } \\
\text { group }\end{array}$ & $\begin{array}{l}\text { I want to work for the government, or alternatively, I may work with } \\
\text { a development project in the city. } \\
\text { After that, I want to return and develop our village as it is not } \\
\text { developed yet. }\end{array}$ \\
\hline $\begin{array}{l}\text { Kao Mua, } \\
\text { Female, } \\
\text { Hmong ethnic } \\
\text { group }\end{array}$ & $\begin{array}{l}\text { After graduation, I want to return and develop our village (to work } \\
\text { for government) as it is still backwards, remote, not developed. } \\
\text { I don't want to live in the city as I don't have relatives here. }\end{array}$ \\
\hline $\begin{array}{l}\text { Somchai, Male, } \\
\text { Kmhmu ethnic } \\
\text { group }\end{array}$ & $\begin{array}{l}\text { I want to change the way our parents make a living [upland farming } \\
\text { system]. I want to escape from poverty, but I am not sure if I can } \\
\text { do it. I want to continue my study until Masters and Ph.D. level. } \\
\text { Then, I want to work for the government. I will make my mom } \\
\text { happy as I am her hope. }\end{array}$ \\
\hline
\end{tabular}

Sources: Interviews (June, 2016).

All youth in agricultural education expected to become entrepreneurs. For example, they wanted to start building their own farms after graduation, mostly nursery gardens (Table 6.4). 
Table 6.4 Aspirations of youth from Northern Agriculture and Forestry College

\begin{tabular}{cc}
\hline Individuals & Examples \\
\hline $\begin{array}{c}\text { Mr. Hankeo, } \\
\text { Oudomxay }\end{array}$ & $\begin{array}{c}\text { My dream after I graduate is to start a farm for my family. Then I } \\
\text { will look for work either with the government, or a business or } \\
\text { even a project }\end{array}$ \\
$\begin{array}{c}\text { Ms. Phaidin, } \\
\text { Huaphanh } \\
\text { money to support my family because my family is a poor } \\
\text { household. } \\
\text { Mr. Thong, }\end{array}$ & $\begin{array}{l}\text { My dream in the next five years is to graduate with a Bachelor's } \\
\text { degree and to have my own nursery garden. If I have a chance or }\end{array}$ \\
opportunity to work with a project or company that sees the value \\
in my abilities and the knowledge I have learned from my \\
education, I would like to work for a company and earn income. \\
My dream will always be my own nursery garden, get married and \\
have children but you never know if that will happen. My father \\
and mother are rice farmers, they only had labour to offer. That is \\
why I want change and to use my education to start my nursery. \\
My dream after I graduate is to have my own business, or my own \\
farm, or anything that will develop a career so I can earn an income \\
to support my family and move us out of poverty. \\
In the next 2-3 years, I want enough to survive, and to eat, to \\
Contribute to my community. I am going to make it my reality \\
because I am the youngest in my family of farmers and the last \\
chance to make it happen.
\end{tabular}

Source: Extracted from SDC (2016)'s online publication.

It seemed, as shown in Table 6.4, the youth studied in this research, plan to work in order to support their families first, as shown in Hankeo's comment, that "My dream after I graduate is to start a farm for my family", and Phaidin too. This suggests that self-sufficiency is the first thing these young people aspired to, before generating more income from other sources, as noted by Kham: "I want enough to survive, and to eat, to contribute to my community."

Overall, there are differences in the aspirations of youth from different institutions, as well as differences by gender and ethnic group. For example, while most youth from NAFC aimed to own a farm business, or at least start from a family-based business, youth from LPB-TVET wanted to purse higher education and work in restaurants. Youth from university, however, all wanted to be employed in the public sector. By gender, while there was a clear divide in terms of what men and women in LPB-TEVET wanted to do and be in the future, there was almost no such difference among youth from NAFC. By ethnicity, we can see that while 
Kmhmu ethnic youth mostly want to work for the government, Lao ethnic youth aimed to work for the private sector. Due to a lack of information we cannot see the preferences of youth from NAFC by ethnicity.

To have a better understanding of youth aspiration, I conducted a focus group in addition to individual interviews. The focus group activity was a helpful way for participants to formulate answers to the question posed. The information presented in Table 6.5 below is taken from Fig. 3.4 (chapter 3).

Table 6.5 Aspirations of youth, expressed in a group

\begin{tabular}{|c|c|c|}
\hline $\begin{array}{l}\text { What resources or } \\
\text { experiences do youth } \\
\text { already have? }\end{array}$ & What is needed? & $\begin{array}{l}\text { What aspirations do youth } \\
\text { hold? }\end{array}$ \\
\hline $\begin{array}{l}\text { Skills and knowledge } \\
\text { that match what we } \\
\text { want to do }\end{array}$ & $\begin{array}{l}\text { Tools/ equipment use for } \\
\text { practising } \\
\text { Higher level of education }\end{array}$ & $\begin{array}{l}\text { To become qualified } \\
\text { technicians and skilled } \\
\text { workers }\end{array}$ \\
\hline $\begin{array}{l}\text { Experiences, } \\
\text { ambitions, } \\
\text { dedication, self- } \\
\text { determination, } \\
\text { perseverance and } \\
\text { social networks }\end{array}$ & $\begin{array}{l}\text { Space/place and technical } \\
\text { support to run business } \\
\text { Knowledge of administration } \\
\text { and equipment and } \\
\text { machine management }\end{array}$ & $\begin{array}{l}\text { To be entrepreneurs and } \\
\text { business owners, including } \\
\text { of famous hotels and } \\
\text { restaurants } \\
\text { To become others' helpers }\end{array}$ \\
\hline $\begin{array}{l}\text { Ability to have a try/ } \\
\text { to experience new }\end{array}$ & Financial support & $\begin{array}{l}\text { To gain care and respect for } \\
\text { what youth value and do }\end{array}$ \\
\hline things/challenges & $\begin{array}{l}\text { Support from individuals, } \\
\text { organisations, and society }\end{array}$ & $\begin{array}{l}\text { To be well-rounded, } \\
\text { physically and mentally }\end{array}$ \\
\hline $\begin{array}{l}\text { action on } \\
\text { something new }\end{array}$ & $\begin{array}{l}\text { Space for youth development } \\
\text { Work place for youth }\end{array}$ & $\begin{array}{l}\text { To contribute to the country's } \\
\text { development and prosperity }\end{array}$ \\
\hline
\end{tabular}

Source: Focus Group, 15/6/2016

In Table 6.5, we can see that aspirations among youth vary. While some want to become technicians and qualified workers, others want to own well-known businesses. There are also those who want to contribute to their country's development and prosperity. To further unpack livelihood aspirations from Tables 6.2 to 6.5 , I classify them into three different categories: migration, aiming high, and grit. Migration refers to youth who wish to out-migrate from rural villages to cities in the pursuit of livelihood betterment; aiming high refers to the aspirations of youth who wish to pursue a higher level of education, and who strive for better living conditions (i.e. to escape from poverty) and self-esteem (i.e. to be well- 
rounded, others' helpers, contributors to the country's development); grit refers to the personality traits of youth who are persistent, perseverant, or ambitious in achieving their aiming-high aspirations. Each of these types of aspirations is discussed separately in the following subsections.

\subsubsection{Migration}

Village out-migration seems to be a common trend among rural youth in northern Laos. As presented in Table 6.2 and 6.3 earlier (also based on interviews, 22/6 to 17/7/2016), Chaiphone was thinking of moving from Nan district to Luang Prabang city. Vattana planned to move from Viengkham district to either Luang Prabang, or Xayabouly province. Sida wanted to out-migrate from her village (Ban Meuang Ngoy) to Ngoy district centre. Davone was expecting to move to Vientiane for further studies. Their reasons for out-migrating were mainly for life betterment, the attraction of a modern lifestyle, and better access to public services. A story from Vattana, presented in Box 6.1 below, is an exemplar of youth aspirations on migration. 
I live in a small, poor, isolated village of Viengkham district ${ }^{13}$, Luang Prabang province. Villagers are all $\mathrm{Kmhmu}$. As it is a highland area, people only do upland rice farming and only a few of them raise livestock. There is no place for lowland farming. The main income of the local people is from selling rice.

Life in our village is miserable. We don't have enough water and it takes several hours to collect the water. I find it difficult to make a living. Therefore [in the past 7 years or so], I left home and lived with a relative in Xayabouly province in order to continue my secondary education.

After that, I studied at Souphanouvong University for a year. Then I dropped out as my parents and relative could not support me. I returned home. Later, I was fortunate to receive a scholarship from the district to study here [LBP-TVET].

I have been thinking, and I feel sad for my parents. They are getting old and living in such hard conditions in the village. I don't want to return home anymore. I want to find jobs and live in the city. Then I will bring them to live with me.

Life in the city is better than at home. As there are many people in the city, we can socialize and exchange ideas to broaden our understanding about things. In the city, life is also more convenient, there are more opportunities for education and selfdevelopment, and is modern (sa-vang-sa-vai).

I am now both studying and working a part-time job. I don't ask for money from my parents at all.

In the future, I want to go into business [furniture-making]. I think it is good as it will not only improve my life conditions, but will create jobs for other people too. I want to help our Kmhmu people as we are looked down upon by others because we are poor.

If I go into business, I will be able to support my children as they look to get a better education, and they can continue running my business as well.

I like doing business because it seems to have more freedom. To achieve my dreams, I plan to continue with a higher diploma next year [Vattana is now taking a diploma programme].

Source: Interview with Vattana, male Kmhmu ethnic group, Luang Prabang TVET $(25 / 6 / 2016)$.

From Vattana's story, we can see that poor living conditions, or pressure at home, have pushed him to out-migrate. In other words, as he described, the convenience, education, job opportunities, and modernity in the city-or what he called 'sa-vang-sa-vai' (water flows, light shines: a metaphor to express the modern living condition of living in the city)—have drawn him away from home in order to enjoy these new environments.

A lack of job opportunities in rural areas seem to be a key reason for youth to migrate to cities. The school director of LBP-TVET explained:

\footnotetext{
${ }^{13}$ Viengkham district is also one of the 47 poorest districts in Lao PDR (Messerli et al., 2008).
} 
Youth rarely return to their homeland after graduation. The reason is because there is no job available at home. To reduce the number of rural-urban migrants, socio-economic development policy shall focus on creating more jobs in rural areas. To do this, development potential at the local level shall be explored and used; and young entrepreneurs shall be promoted. Hence, more job opportunities will be available for newly-graduated youth (Interviews, 21/6/2016).

The above quote suggests that expanding the rural economy is vital to prevent rural-urban migration on a large scale in the near future. In fact, rural-urban migration has become a trend in Laos. An in-country study on migration in Laos revealed that youth and unmarried populations, especially women, are the largest groups of out-migrants (Mujahid, Laxasy, Boutlasy, Sengaloun, \& Siphaseuth, 2011). Aspiring for higher education and income earnings are the key factors driving youth to cities, leaving many elderly people in the countryside (Mujahid et al., 2011). The study also reported that policy and interventions related to migration have not yet been well established. To ensure a more sustainable way of doing development, rural-urban migration may need to be balanced.

Some rural youth, however, did not want to out-migrate from the village. A story from Kao Mua (Box 6.2), a Hmong ethnic group, who lives in the remote village of Huaphan province, is an example supporting this argument. 
Box 6.2 Home, sweet home - "I don't want to live in the city"

I live in Ban Khangkhao, Huameaung district ${ }^{14}$, Huaphan province. There are around 200 households in our village. It is located on the road side, $18 \mathrm{~km}$ from the district headquarters, and the condition of the road is pretty good.

Lots of forest land areas are protected. As there are many big trees, the climate is cool and nice throughout the year.

People in our village rely on the natural resources to make a living. They do upland rice farming, growing vegetables and corn. They don't raise buffalos and cows as most of the time the animals die of diseases.

Life in the city is hard. Accommodation costs are high and I don't have many friends. I have a few friends, but we are not close. In the city, there are lots of social issues as well. Also, we have to spend a lot of money in the city which was very different from living in our village.

As the city is not my hometown, I find it difficult to make a living. I don't know how to do it. I don't know many people and they don't know me either. All of these make me feel like I don't want to live in the city.

Life at home is relaxed and there are no chemicals in the food we eat. There are not many difficulties. I prefer to live in the village as it is convenient and our relatives are there.

I want to use my obtained knowledge to help people in my village doing business and improve their lives.

At home, we have lots of natural resources such as Non-Timber Forest Products (NTFP) that we can reproduce and use to add more value. I notice that people collect and sell with low prices because they don't know how to reproduce them. After studying Food Science and Technology (FST), I know how to do that. I also know how to preserve food. I want to teach what I learned to the people at home as well.

Source: Interview with Kao Mau, female Hmong ethnic group, Souphanouvong University $(17 / 6 / 2016)$.

For Kao Mua, the abundance of natural resources, and the simplicity of life and relaxing atmosphere of her remote village seem to be the main factors that keep her close to home. She also illustrated well the challenges she faced living in the city during her years there for education. These challenges include the difficulty of making a living in the city, as well as the lack of social capital, both of which lead to a lack of financial capital. It seems, for Kao Mua, living in the city is stressful and cash-dependent, and not a preferable lifestyle. Her homeland, on the other hand, offers a more relaxed lifestyle. Social and support networks of close friends and family seem to be a vital factor that attracted her home.

Kao Mua also has a clear vision and the intention to help her people at home improve their living conditions. She wishes to bring the practical knowledge and

\footnotetext{
${ }^{14}$ Huamenag district is one of the 47 poorest districts in Lao PDR (Messerli et al., 2008).
} 
skills gained from university back home to share with her people. It seems that Kao Mua's intention of returning home was not only because she didn't like living in the city, but also to pay back the rewards, such as the support she received from her community.

\subsubsection{Aiming high}

Most youth aimed high for their livelihoods. As we can see from Tables 6.2 to 6.5, the characteristics of youth aspirations vary, ranging from the state of 'having' (i.e. wanting to obtain skills and knowledge) to the state of 'becoming' (i.e. becoming technicians, skilled workers), the state of 'possessing' (i.e. owning businesses, famous hotels and restaurants), the state of 'being' (i.e. being well-rounded and developed, or helping others), and the state of 'being self-esteem' (i.e. contributing to the development and prosperity of their own country).

Youth who had been living in deprived situations were highly passionate and had faith in the power of education to later transform their lives. The life story of Somchai who was studying at Souphanouvong University illustrated in Box 6.3 below strongly confirms this statement. 
Box 6.3 Aiming high - "I strive to escape the poverty of our family"

In the past eight years or so, I lived in a very remote village of Namo district ${ }^{15}$, Oudomxay Province. I walked several miles to school and had to carry my own bag of rice with me on my trek to school. My journey to education was not as smooth as many others who live in the city. My parents worked in the highland rice field and they collected non-timber forest products to sell in order to support me.

During my secondary education, my younger brother passed away due to an accident. Not too long after that, my father passed away. I was so down and I left school when I was in M4 (Grade 9) to help my mom make a living and to support my younger sister's education.

I could not stand seeing my mom and my family living in poverty. Later, I asked my mom for her permission to continue my studies, but she rejected this because there was no one helping her with farming and housework.

I did not give up and was determined to follow my passions. I decided to come back to school until I finished M7 (Grade 12) and pursue higher education here [Souphanouvong University of Luang Prabang].

I was told by many people in my village that I had made the wrong decision. I would admit if I had made a wrong decision in choosing to follow my passions, but I know this is the right thing to do. I do this because I wanted to change the way we make a living. I strive to escape from the poverty of our family, though I am not even sure if this could be possible. I don't know if there is another way to escape from poverty besides having good education.

Source: Interview with Somchai, male Kmhmu ethnic group, Souphanouvong University $(17 / 6 / 2016)$.

The story of Somchai paints such an empowering picture of individuals who live in hardship in remote villages and poor districts, but who maintain their dreams and passions to strive from such situations. His final statement shows how he strongly believes in the power of education, or human capital, that will help transform his life and family.

The act and power of aspirations can be clearly seen in the case of Somchai too. For example, he has been striving to withstand so many adversities throughout his life - the death of his younger brother and later his father, combined with the persuasion of his mother wanting him to stay home. It seems that Somchai's aspirations and determination have been the fire that kept him going and these in return have brought about changes and satisfactory outcomes for him.

From a human capabilities perspective (Sen, 2001), an individual youth, like Somchai, has the freedom to act upon what he aspires towards - what he wants to do and be. It can also be said that Somchai was capable in turning threat to

\footnotetext{
${ }^{15}$ Namo district is one of the 47 poorest districts in Lao PDR (Messerli et al., 2008).
} 
opportunity - that is, seeing poverty with optimism and using it as an instrument in the pursuit of betterment, rather than seeing poverty as pessimism and letting it discourage him in his life and passions.

However, Somchai's case cannot be generalized to apply to all cases among youth. As we can see in Table 6.5, youth require additional resources to help them realise their aspirations. Among other resources, youth particularly emphasise the need of financial capital. Views from parents were consistent with what youth mentioned about the lack of finance. An example can be seen from the following statement by the village head of Ban Huayman, who said:

The challenge is that students are unable to access credit, after their graduation. As a result, they are not able to start their own business. We, as parents, could not support them in terms of finance. We can only teach them to be good persons in the society (Interview, 1/7/2016).

In their study, "Assessment of Credit Possibilities for Graduates from the Northern Agriculture and Forestry College (NAFC) and other Agriculture and Forestry Colleges under the Ministry of Agriculture and Forestry (MAF) to start up their own micro or small enterprise", Bourgeois Lüthi and Phangphongphakdy (2014) report that "access to capital, mainly start-up capital remains difficult especially for young entrepreneurs" (p. 32). They also find that severe restrictions on financial capital are particularly found among youth from remote villages. This suggests that increasing access to finance in remote villages is essential, if career aspirations and the potential of youth are to be realised.

\subsubsection{Grit}

In psychological terms, "Grit is a personality trait defined as passion and perseverance for long-term goals" (Duckworth \& Eskreis-Winkler, 2015, p. 397). The authors assert that "in the face of adversity, failure, and plateaus in progress, gritty individuals hold steadfast to their commitments - not just over weeks or months, but over years and decades." As such, Somchai's case is an exemplar of these authors' assertion. For instance, Somchai failed in his attempt to continue studying at M4 (grade 9). However, he recovered his dreams and pushed through adversity until reaching university, and beyond, now aiming to pursue study to Masters or Ph.D. level (as mentioned in Table 6.3). 
Other cases in this research demonstrate how gritty rural youth in the northern region of Laos are. Ms. Sida, a Kmhmu female student studying at Souphanouvong University, told her story by describing her village situation, her motivation to pursue education, the challenges she encountered, and her strong belief to overcome all the challenges (Box 6.4).

Box 6.4 Perseverance - "Where there is a will, there is a way"

I live in a remote village up north of Ngoy district ${ }^{16}$, Luang Prabang province. In the past, forest resources were abundant, but now are very limited as our village was regrouped. Many people from other village(s) have in-migrated and the forest was cut for upland rice farming. Lowland rice farming is under expansion. Some people in the village raise livestock, sell things at home, and collect Non-Timber Forest Products for sale. Just that. No market, no big business, and no tourism in our village.

I have realised that the reason people in our village have been doing upland rice farming is because they have a low level of education. They do not come to the city in order to learn development from others and then apply it to our village.

I have been thinking what I should do to make a living in the future, as cutting down the forest for shifting cultivation is now prohibited by the government. Hence, I have never thought of dropping out of school, rather I have been thinking a lot about studying.

Life in university is hard. Financial issues, difficulty in understanding lessons, and low computer and English language skills. No matter how hard it is, I will try my best to overcome it. I believe 'where there is a will, there is a way.'

My parents are very supportive of me. When they do not have money to send to me, they borrow from our relatives and other people. They want me to a have better life like others.

Thanks to such hardship, I have never changed my mind in continuing my study with the aim of bringing about change for our family in the future.

I am inspired by our teachers as well. They graduated from overseas, some have Masters, others a Ph.D. They told us they went to many countries around the world. I want to be knowledgeable and capable like them. I want to see other countries and experience them myself.

Source: Interview with Ms. Sida, Kmhmu ethnic groups, Souphanouvong University $(17 / 6 / 2016)$.

What is clear for Sida's case is the power of her perseverance. In addition to her determination to study, Sida told me that friends attempted to persuade her to move and work in the factory in Vientiane before she decided to enter university, but they were not able to change her mind (Interview, 17/6/2016). This indicates how her strong persistence has brought her to university and fuelled her with

\footnotetext{
${ }^{16}$ Ngoy is non-poor district (Messerli et al., 2008).
} 
determination to continue; otherwise, she could have left school and followed her friends in Vientiane.

Another indication of Sida's grit is that she constantly pushed herself towards what she wanted to do. As she stated "No matter how hard [my life] is, I will try my best to overcome it. I believe where there is a will, there is a way."

More recent psychological literature, like Duckworth and Gross (2014), claims that individuals with grit are more likely to be successful in both academic and professional life, despite the obstacles and setbacks they encounter, than those who have talent and opportunities. And grit can be considered among an individual's assets, or the human capital that they exercise for livelihood betterment. Chapter 7 will explore how TVET can enhance individuals' grit.

\subsection{Summary}

This chapter has revealed that rural youth in the research context perceive education as critical and relevant to their livelihoods. TVET is perceived as attractive and practical rather than theoretical. Knowledge and skills provided by TVET are also considered relevant to the needs of the labour market. The chapter has explained that educational decision-making among rural youth is somehow collective. Family, school, and social networks all have an important role to play throughout the decision-making process of youth considering their education options.

Furthermore, the chapter has explained that the aspirations of rural youth are diverse. In addition to aspiring towards migration, rural youth aim high and are gritty. The aspiration of rural youth are high and extend beyond achieving economic wellbeing; they aspire to achieve other, multiple dimensions of human experience. However, some rural youth have experienced social, cultural, and economic constraints in achieving their dreams.

Addressing these social pressures will not only help them to realise their potential and dreams, but also to acknowledge youth as active citizens and to promote, by and large, the freedom and democracy of youth to pursue their dreams and honour the human need to flourish in multiple ways. To what extent has TVET helped, or can it help rural youth in Laos achieve their aspirations? This is explained in the subsequent chapter. 
This page intentionally left blank 


\section{Chapter 7}

TVET and development in Laos: Priorities, challenges and areas for further attention

\subsection{Introduction}

In chapter 4, I explained development strategies and funding for TVET development in Laos. I have shown that the central objective is to use TVET as an instrument for poverty reduction and economic growth. In chapter 5, I examined the current livelihood activities in two rural villages of Luang Prabang province. I have explained that while some households have moved to non-farm-based livelihood systems, many still work on farms, in most cases unproductive farms. In chapter 6, I explained that most rural youth want to move to cities in search of jobs and better education. I have highlighted that their aspirations are high and rural youth are gritty.

This chapter brings all these together, including the policy review and literature presented in chapter 2. It examines the extent to which TVET policy and interventions are relevant to the aspirations of rural youth in the context of this research. The chapter provides answers to the third research sub-question: 'How do current potential TVET approaches align with the current livelihoods and aspirations of youth in rural Laos?'

The chapter proceeds as follows. Section 7.2 examines the development priorities for TVET development in Laos and how they support the needs of people at the local as well as the national levels. Results show that many issues remain unsolved, thus attention to TVET development is required. Section 7.3 examines the causes of these challenges by analysing the issues around policy development, interventions, and education approaches. Results show that they are inadequate to meet the aspirations of rural youth. Finally, section 7.4 proposes a possibility to 
incorporate the capability approach into TVET policy, programmes, and activities in order to help rural youth achieve their aspirations.

\subsection{Priorities and challenges for TVET development in Laos}

This section discusses key development priorities and remaining challenges for TVET development in Laos. The below subsections are organised based on the findings to have arisen in this research. The first subsection discusses how the government has used TVET as an instrument for reducing poverty and fostering economic growth. The second subsection examines how the government has attempted to address the current issue of the skills mismatch between the demands of the labour market and the skills supply of TVET. The third subsection assesses the extent to which government has attempted to raise the attractiveness and recognition of TVET. Result shows that the goals of poverty reduction and economic growth will not be achieved unless the issues of skills mismatch and the unattractiveness and low recognition of TVET are addressed.

\subsubsection{Reducing poverty and increasing economic growth}

The first development priority area of TVET in Laos is to achieve the targets of poverty reduction and economic growth. Doing so will help the country achieve its goal of graduating from the list of Least Developed Countries by 2020, and of supporting the industrialisation and modernisation process (Hilal et al., 2016; MOE, 2007b). To explain how TVET is used to achieve these goals, I examine its development in relation to three main sectors: agriculture, industry, and service.

In the agricultural sector, TVET is viewed as an instrument to ensure food security, livelihood improvement, and rural poverty reduction, (MAF, 2008; SDC, 2009). To achieve this, agricultural skills are provided for rural youth. Youth are then expected to help farmers to improve their farm activities, as well as to gain employment, thus improving individual and household economic welfare (SDC, 2009, 2012). To some extent, this expectation seems to be positive. For example, a tracer study conducted by Schroeter (2015) revealed that around 80 percent of 126 graduates from the Northern Agriculture and Forestry College (NAFC) were employed. 
However, evidence from the two visited villages suggests that agricultural skills and knowledge are inadequately supplied to youth and farmers. A number of households still engage in unproductive agricultural activities, thus remaining poor. Similar evidence is found in the report of AusAID (2012). It argues that farmers in rural Laos lack relevant skills and knowledge. Therefore, they cannot produce surplus agricultural outputs for sale. Hence, they are locked into the vicious cycle of poverty.

Inadequacy of agricultural skills is caused by paying too little attention to the role of TVET in the agricultural sector, both in terms of technical and financial assistance, but too much attention to general education, especially in primary education (MOES, 2009). Although an aid donor and an NGO, as explained in chapter 4, have attempted to support agricultural colleges in Laos, these are inadequate to providing the skills needed for many parts of the country. For example, MOES's assessment revealed that only 12 percent of students enrolled in TVET (MOES, 2016). This shows that TVET's policy response has not fully met the needs of local people, especially those who rely on agriculture for livelihood security.

As I have explained in chapter 4, a large proportion of poorer populations, especially ethnic minorities, reside in rural areas and work in the agricultural sector. If agricultural skills are not adequately provided, the current poverty rate in Laos will remain, at least for a decade to come. This may prevent the country from achieving its Sustainable Development Goals (SDGs) by 2030-especially goal number one, to "End poverty in all its forms everywhere" (United Nations, 2015b, p. 14) - if a proper plan is not well prepared. Raising agricultural productivity through the promotion of TVET, therefore, should be the top development priority for Laos (World Bank, 2014a). As the World Bank (2014a, p. 12) observed:

In the shorter term, higher agricultural productivity will help generate better livelihoods for the 4.5 million Lao people [approximately 69 percent of current total population] living on farms. Over the longer term, increased productivity on the farms would eventually lower the need for labour, freeing up agricultural workers to move to more productive jobs in other sectors. 
Therefore, if poverty is to be reduced, and the economic growth is to be robust and inclusive, more investment of TVET in the agricultural sector is urgently needed.

In the industrial sector, TVET is particularly vital for Laos to ensure its country's industrialisation and modernisation transformation. A government official from MOES explained:

Our country is in the initial stage of industrialisation and modernisation. Foreign direct investment [FDI] is increasing, sectoral investment is expanding, and investment in special economic zones [SEZs] is mushrooming across the country. Hence, non-traditional jobs/trade areas such as automotive, electrics/electronics engineers, hospitality, and so forth are needed in the industrial sector. The SEZs alone, for instance, have been established in 17 to 18 areas in the different provinces. Take the SEZ in Savannakhet province for example, around 30,000 to 40,000 workers are needed. However, not many Lao people choose to study in the TVET where skills offered are directly relevant to industrial needs (Interview, 9/8/2016).

The development of Special Economic Zones (SEZs) is the government's strategy to attract FDI, accelerate the industrialisation process, and create more job opportunities for local people not only in the cities, but also rural towns and border areas where SEZ sites are located (GMS Secretariat, 2016; Lao PDR, 2010). According to Noonan (2015, p. 10), “The SSEZs ${ }^{17}$ [or SEZs] are important sites for domestic and foreign investment to support economic growth and transforming Laos into a modern industrialized economy. The public TVET institutions are the government's major instruments for providing the HRD [human resource development] needed for this transformation."

However, according to the government official's statement earlier, the number of graduates that TVET supply is insufficient to the demands of the industrial sector. This argument is reaffirmed by Noonan (2015, p. 9) who argues that "there is a serious imbalance between demand implicit in the SSEZ projects and supply provided by TVET institutions under MOES." To address the imbalance between skills and labour markets, according to Noonan (2015), human resource

\footnotetext{
${ }^{17}$ Special and Specific Economic Zones. The terms, SSEZs and SEZs are used interchangeably in this research.
} 
needs analysis should be urgently conducted on a larger scale, from local to provincial and national levels, and detailed human resource development action plans should be prepared. I propose that the study and action plans should not only focus on what is needed for SEZ projects, but also other large industrial sectors, such as the garment, mining and hydropower industry where a significant labour force is required (Lord, 2012).

Policy interventions of aid donors supporting TVET development in Laos have not concentrated on the needs of labour within SEZ projects, nor on the skills required for adults, or young people, in rural border areas where economic corridor development projects exist. In fact, expansion of TVET in such rural areas is required (GMS Secretariat, 2016). SEZs and economic corridor development can promote not only overall economic growth and regional integration, but also local development (Bafoil, Diaz, Guerin, Morris, \& Sen, 2016). In this sense, it can be argued that the inadequacy of policy response in the industrial sector equates to the irrelevance and incoherence of the country's TVET policy development and planning.

The tourism or service sector in Laos is a fast growing industry contributing significantly to economic growth (Yamauchi \& Lee, 1999), poverty reduction, and livelihood improvement (Harrison \& Schipani, 2007). Tourism, especially in rural areas such as Ban Meuang Ngoy, provides people's livelihoods. While little attention has been paid towards the role of TVET in promoting rural tourism in the country, in theory, "[t]ourism has proved to bring more benefits for disadvantaged groups at local levels than at national or regional ones" (Sharpley and Telfer, cited in Palomino-Schalscha, 2012, p. 193).

In Laos, a key development partner supporting MOES to provide "skills for tourism" is the government of the Grand Duchy of Luxembourg, through the Luxembourg Development Agency (LDA, 2012, 2017a, 2017b; Semone, 2012). A key objective of the current project (2016-2021) is to help in "bridging the gap between the large number of job-seekers in Lao PDR, particularly those from disadvantaged backgrounds, and the enormous employment potential of the tourism and hospitality sector" (LDA, 2017b, p. 2). LDA's targeting of disadvantaged groups is not only to enlarge livelihood choices, but also to ensure social inclusion and sustainable development (LDA, 2017a). This kind of project is directly linked to the needs of rural villages where tourism is essential for livelihoods. If local 
people obtain basic tourism skills and management, they will be able to provide good service to visitors and more likely to maintain ecotourism activities in sustainable ways. Thus, their income will be increased and their livelihoods sustained (Harrison \& Schipani, 2007).

Overall, in this section, I have explained that the government of Laos has attempted to improve TVET to meet the needs of socio-economic development, the private sector, and local people. And yet the policy and interventions have not adequately responded to these needs. There are two key reasons behind this issue. One is the issue of skills mismatch. The other issue is the unattractiveness and low recognition of TVET. Each of these will be explained in the following subsections.

\subsubsection{Addressing skills mismatch}

To restate, the mismatch between what skills are required for the labour market and what is supplied by TVET, both in terms of quality and quantity, is an issue in Laos (World Bank, 2013). To address this issue, with the support of international institutions, the government of Laos has shifted its development strategy from a supply- to demand-driven approach. A TVET expert from GIZ explained that:

We, [under the VELA programme], support the government to reform TVET from a supply-driven approach to a demand-driven approach. We expect that learners will be equipped with skills that meet the needs of the labour market. The low technical profile of workers will be enhanced. Workers' pay will be increased and their livelihoods will be improved (Interview, 1/8/2016).

According to the interviews, at least three strategies have been established to ensure the implementation of the demand-driven approach. First, influenced by the German TVET development model, a dual cooperative training (DCT) system has been introduced in Laos (Interview with TVET experts, and government official, 1, 9/8/2016). However, our understanding of the application of this system is very limited. A TVET expert, an insider whom I interviewed, asserted that the system has already been 'adjusted' based on the socio-economic context of Laos (Interview, 1/8/2016). I am, however, sceptical as to whether or not the system is well adjusted. In their study on the extent to which Germany's dual system can be transferred or applied in an Asian context, for example, Hummelsheim and Baur (2014) warn that the system must be carefully applied. They emphasize that "any 
transfer must reflect the existing conditions in the country adopting the system, and must be adapted to its unique social, cultural, and economic objectives" (Hummelsheim \& Baur, 2014, p. 279). Further investigation on the application of supply-driven approach in the Lao context would be ideal, especially in terms of its relevance and applicability.

Second, in supporting the demand-driven approach, the competency-based training (CBT) model has been in place. A government official explained that:

In the past two years, MOES has applied the CBT model and reduced the duration of courses, to 3 to 6 months [Certificate level 1] and 6 to 12 months [Certificate level 2] so to ensure more people from rural areas can access TVET. And yet we need SMEs to help us ensure that these graduates can start small business after graduation (Interview, 9/8/2016).

It can be seen that the main purpose of applying this strategy is to address the needs of rural people by designing short courses for them. This strategy seems to be directly relevant to some in rural areas, and will attract them to attend TVET. However, the challenge is how to ensure financial access for rural people after their graduation (this issue has already been explained in chapter 5). Cooperation for development between the private sector and TVET is, therefore, required. This leads me to discuss the third strategy.

Finally, the government encourages the private sector in the development of TVET. And yet, according to TVET experts and a government official (Interview, $1,9 / 8 / 2016$ ), such encouragement in development of TVET is relatively new. In the context of curriculum development, for example, they said, MOES is still the only key institution responsible. A TVET expert explained that in industrialised countries such as Germany, and other countries in Europe, the private sector takes greater responsibility for curriculum development so that it meets their own requirements (Interview, 1/8/2016). Should the autonomy and control of TVET be handed to the private sector? This may be a critical question to raise for better TVET development in Laos. However, it can be politically sensitive and the suggestions on this must be carefully made (I will discuss political sensitivity in section 7.3). To my end, one possible option to encourage the private sector into TVET is to reinforce the revised version of Vientiane Declaration (VD) - the localised version 
of the Paris Declaration on Aid Effectiveness-which specifies "Business as a Partner in Development" (Lao PDR, 2016, p. 8). Also, the cooperation between the government and the private sector can be made through the Public-Private Partnerships (PPPs) (ADB, 2010c; UNESCO, 2013).

The application of the demand-driven approach seems to be appropriate in helping some youth to achieve their livelihood aspirations. Educators and youth in LBP-TVET, for example, explained that, through the DCT and CBT, a number of graduates receive jobs with the companies or restaurants they have practised their work with (Interview, 15, 26/6/2016). However, it cannot be claimed that the approach is successfully applied. In the near future, research on the impact of such an approach is needed. Until recently, skills mismatch is still an issue. As Somphone argued, "everyone is talking about skills mismatch, but I don't see any detailed strategy and plan to address this issue [emphasis added]" (Interview, 11/8/2016).

Skills mismatch is a pressing challenge facing not only Laos, but many other countries in the Asia and Pacific region (Maclean, Jagannathan, \& Sarvi, 2013). Jagannathan (2013, pp. 370, 372) argues that, in the context of Asian economies, "addressing skills mismatch calls for not just upskilling but also right skilling" by "aligning skills training policies with economic and industrial policies." Countries like Korea, Singapore, Hong Kong, and China have demonstrated a "strong case for successfully integrating education and policies for skills development into nations' overriding frameworks for economic development" (Jagannathan, 2013, p. 372). Moreover, Almeida, Behrman, and Robalino (2012) state that decentralisation of TVET by giving authority and decision-making power to employers and other stakeholders to oversee the operations of individual TVET institutions is a key factor of success; and incorporating demand-driven TVET into the national industrialization strategy is also crucial in order to address the skills mismatch issue. Laos may consider these as lessons to learn from.

\subsubsection{Raising attractiveness and recognition of TVET}

Key reason that TVET cannot support the demand of the labour market in the country is because the majority of the population view it as unattractive and less recognised. As explained in chapter 6, TVET-related work is regarded as "difficult, dirty, and dangerous," with TVET skills leading to blue-collar work which is not a 
preference for many people. Somphone, an education specialist, further explained that:

No one wants to take up TVET as the cost of labourers with TVET skills is low. And no one in Lao society wants to work in a subordinate position, but at managerial level. People believe that if taking TVET they will become labourers, not professionals. Because of this societal and cultural norm, people do not want to engage in TVET (Interview, $11 / 8 / 2016)$.

It can be seen that the unattractiveness of TVET is related to not only career prospects, but to social and cultural norms. In Laos, interpreting from the above quotes and also based on my personal experience, whoever works as a labourer is perceived as lower-class in society. In fact, Laos is not the only country experiencing such a challenge in TVET development. Elsewhere in Asia, countries such as China and Korea have also experienced similar issues. The Confucius belief, for example, influences the people of these two countries to perceive TVETrelated work as lower-class (Ratnata, 2013). In the context of Laos, Buddhism does not cast labourers as lower-class, but the influence of history, in terms of race and ethnicity from ancient times to more recent colonial periods (Evans, 2002; StuartFox, 1997, 2001, 2008) may affect the way people now perceive a type of work. Further investigation on this issue would provide clearer understanding.

The unattractiveness of TVET is a heated debate in Laos. According to the MOES's magazine published on $4^{\text {th }}$ January 2017 , the Prime Minister recommends urgently addressing the societal misconception of TVET, and suggests that people should choose to study programmes that are relevant to the needs of the labour market (Education and Sports Magazine, 2017). Somphone emphasised:

The government policy in promoting people to enter TVET is right as the demands of the labour market in Laos do not necessarily require graduates of bachelor or master degrees in order to perform their tasks... The government has provided incentives to attract people entering TVET, such as providing free accommodation, free registration, and some allowance [scholarships]. And yet not many people are interested in it. The challenge for the Lao government is to encourage more people to attend TVET (Interview 11/8/2016). 
The government's attempt is to make TVET more attractive and widely recognised as a valid educational path. Under the STVET project, for example, over US\$400,000 was injected specifically for the Social Marketing Campaign (SMC) (MOES, 2015a). The central aims of the SMC are to enhance people's understanding, improve the quantity and quality of TVET, and increase the general interest of people in TVET, especially among women and ethnic groups. Key activities include disseminating TVET information through several forms of media and providing training programmes to various target groups, including students, parents, teachers, and private firms (MOES, 2015a). The campaign has also reached some rural areas, including the districts I visited.

However, as the reputation of TVET is culturally embedded, it could take some time before people's perceptions and attitudes change in Laos. At the time my research was conducted, the SMC was under assessment. According to the observation of a government official from MOES who runs the campaign, this approach has encouraged more people to access TVET, with enrolment increasing almost six-fold in the past five years (2011-2016). He stated:

The implementation of a Social Marketing Campaign is quite successful. For example, in 2010/2011 there were only 909 students enrolled in TVET. The number increased to 3,109 in 2013/2014 and almost 5,000 in 2015/2016 academic year. Also, the design of shortterm programmes $(\mathrm{C} 1,2)$ is particularly appropriate for students from ethnic groups living in remote areas.

The MOES official sounded positive for TVET; however, there is no guarantee that TVET will become attractive through a single approach like the social marketing campaign. Study elsewhere (Stasz et al., 2014), for example, noted that people's behaviour and attitudes towards TVET are derived from numerous factors, thus an awareness-raising approach through campaigning is not always sufficient to bring about changes.

It has been proved that the status and role of TVET in many countries around the world is shaped by historical, cultural, economic and social factors (ArthurMensah \& Alagaraja, 2013). TVET is regarded as the "second best or even a choice of last resort" (Marope et al., 2015, p. 12). Worst, in some countries, "TVET was 
widely perceived as a 'dead-end' stream" (Marope et al., 2015, p. 94). In this sense, it can be argued that raising attractiveness of TVET is still a global challenge.

In the context of Laos, TVET is not well known among rural communities. In the villages I visited, for example, most community members commented that they had not heard about the government campaign (Interview, 9/7/2016). The TVET experts whom I interviewed also suggested further expanding of the campaign to more remote villages (Interview, 1/8/2016).

A solution to improve the attractiveness and recognition of TVET, based on the findings of this research, is perhaps to expand its offer by emphasising entrepreneurial skills. This is because such skills are wanted by many of the youth interviewed. If TVET offers entrepreneurial skills and if the government provides an 'enabling' business environment, their parents, and private firms might find TVET attractive too. To ensure a robust economic growth in Laos, improving young people's entrepreneurial skills and enabling a smoother business environment, as well as promoting Small-Medium Enterprises (SMEs), are also advised by several national and international experts working in the country (World Bank, 2015). This validates my argument that providing entrepreneur skills through TVET is essential.

Overall, through this first half of the chapter, I have examined the extent to which current TVET policy and strategy responds to the needs of socio-economic development, and the actual needs of the local people. I have argued that the quality of skills and the quantity of the labour force that TVET provides are inadequate to meet demands at the national level, as well as the local one. In the second half of the chapter, I will explain why this has happened and provide suggestions for further consideration. In so doing, I will examine how TVET policy and planning is created, and what education approach is applied to help youth learn effectively so that their dreams can be realised. Finally, I will propose to apply a capability approach in education in Laos.

\subsection{Socio-political contexts reflecting TVET development challenges}

\subsubsection{Policy development and planning}

In the first decade of the 2000s or so, the public policy development and planning system in Laos has shifted from solely top-down to a mixed system - a combination 
of the top-down and bottom-up approaches (MPI, 2013). The Ministry of Planning and Investment (MPI) is a key planning organisation materialising the political directions of the Lao People's Revolutionary Party (LPRP) congress. Following the political directives, the ministry provides advice and prepares planning and budgeting guidelines and sends them to respective central, provincial, and local organisations (MPI \& JICA, 2010). National development priorities are firstly identified, and guidelines and budget norms (budget ceiling) are developed by MPI. The concerned ministries and provincial organisations then prepare their development plans in accordance with the MPI's guidelines and budget norms, and all plans are submitted to MPI for assessment and consolidation, before proposing to the National Assembly (NA) for endorsement (MPI \& JICA, 2010).

Another development planning mechanism is the Round Table Meeting (RTM) process. This process, established in the year 2000, led by MPI, is an openspace for consultation and negotiation for national development project planning, design, and implementation. Every three to five years, High-Level Round Table Meetings (High-Level RTM) are organised to provide inclusive forums. Every year, the Implementation Meeting (IM) is held in order to review and adjust the plans. Currently, there are ten Sector Working Groups (SWGs), including education and agriculture sectors, and which consist of concerned ministries, donors, civil society, and private sector who are the members of the RTM (DIC, 2017). It can be said that the established policy planning system, both in the public sector and as a combined mechanism, is somewhat political.

These policy planning mechanisms influence sectoral development planning such as education. The mixed policy planning approach, however, has not been applied in the context of education. Education development policy and planning is still a "top-down" approach (Chounlamany, 2014, p. 2). The administration and control of the education system remain primarily at the hands of the central ministry, limiting the implementation of reforms in practice (Chounlamany, 2014).

Education policy development in Laos is heavily influenced by aid-donors (Phommalangsy, 2013) and partially by NGOs (Saeng Outhay, 2015). Rigg (2009, p. 718) takes the argument beyond the education sector and argues that the policy development in Laos is based on a "Vientiane-centric viewpoint," and that policies are seen as "technocratic and managerialist efforts informed by a global discourse of development and administration." Noticeably, the RTM process is the space 
where aid-donors exercise their politics of development, while maintaining some degree of local (Laos as a country) power. The negotiation of aid and policy planning in Laos reflects what Rigg (2016, p. 199) writes in his book Challenging Southeast Asian Development: The shadows of success, that "all development is political." In short, it can be argued that policy development and planning in the Lao context is political and hierarchical, and influenced by aid-donors and NGOs.

Returning to TVET in the context of this research, I observe that the development planning system is a 'donor-led' initiative. The key concern is that without adapting to the local context, the approach may lead to the destruction of local culture and that TVET policy may be further disconnected from livelihood systems. If local people's priorities, approaches and perspectives are promoted, then TVET development will be more relevant, attractive, and sustainable.

Crucially, a comprehensive TVET policy plan must be primarily based on the evidence, and upon recommendations from several development research resources and studies that are available in the country, as well as other countries (Williams, 2005). An example that supports this argument can be seen from Somphone's comment. When asked: What are the opportunities, or policy options to effectively help young rural ethnic groups to achieve their aspirations? He replied:

I recommend the development partners to conduct evidence-based research and reveal its findings to the government. The government also should take into account what issues are found and prepare an action plan to address them (Interview, 11/8/2016).

Somphone's suggestion implies that in order to address the issues around the TVET subsector, the government and its development partners need to work together, rather than having donors take a leading role in development planning. As solving poverty is a high level of priority for Laos (Lao PDR, 2004), I argue that a holistic development planning model should be established. Development planning process and management should be inclusive to all participants from various stakeholders - the government, donors, civil society, private sector, communities and youth. It is quite well known that bottom up approach development planning is useful. As the World Bank (2016) noted, engaging communities, including young men and women, in development planning and management is key to success as it promotes local commitment and empowerment, as well as project ownership and 
sustainability in the country of Laos. This example highlights the importance of taking local voices into account in TVET development.

Overall, the task of this section is to argue that Lao education policy, especially TVET, is influenced by the national and international politics of development discourse, resulting in the mismatch between policy design and the actual needs of local people. However, in education, examining the policy context is not enough. It is particularly crucial to analyse what is actually happening in the classroom as it is the place where teachers and students interact and exchange knowledge, and where we can see more clearly whether or not education has helped learners to achieve their dreams.

\subsubsection{Education approach}

As explained earlier, the overall purpose of TVET development in Laos is to prepare individuals for work, improve the economy, and alleviate the poverty of the country. However, findings in my research, as presented in chapter 6 , reveal that the aspirations of rural youth are beyond households' poverty reduction. Youth aspire for social justice (for instance, aspiring towards respect from society), freedom of life (aspiring towards being acknowledged for what youth value and what they want to do and be), and self-esteem. Chapter 6 findings also show that youth are gritty. They want to improve their personality traits; to maintain their persistence, perseverance, passion and ambition; to be well-rounded, or holistically developed; and to gain respect from the society on what youth value, love and are passionate about.

In an education setting, a method to help boost the aspirations, passions, and motivations of youth is teaching. Teaching methods, as explained in chapter 2, consist of two types: the teacher-centred (conservative) approach and the studentcentred (progressive) approach. The following paragraph examines the extent to which the current teaching approach set by Lao's education policy can support youth achieving their aspirations.

The government's attempt to improve student academic performance and help them achieve their dreams is by reforming the education approach, from teacher-centred education to student-centred, or learner-centred education (Chounlamany, 2014; Lao PDR, 2014, 2015). The approach, however, is not easy to apply in Laos. The political, social, cultural, religious, gender and ethnicity 
factors all make the application of such an approach difficult (Chounlamany, 2014). The approach sometimes creates tensions for teachers required to adapt it into the culture of teaching and learning (MacKinnon \& Thepphasoulithone, 2014). Moreover, people have different understandings about approach and the way in which it can be put into practice (Nordin \& Öberg, 2012). Worst of all, in the context of TVET, the approach has not yet been applied at most TVET institutions (Phomilay, 2012). These challenges suggest that there is little hope that education institutions will help youth achieve their aspirations.

Youth need teaching approaches that can inspire them and boost their interests, passions and grit. Youth, as learners, must be empowered through TVET (Marope et al., 2015). Therefore, TVET providers in other countries have shifted their policy towards "focusing on learners, supporting learners throughout life, and developing policies to support TVET learners making life and career choices" (Marope et al., 2015, p. 117). As such, TVET systems need to be improved, its offer needs be expanded, and a lifelong learning environment should be established, if desired development outcomes are to be met through TVET.

The following section suggests an alternative approach to enable not only youth, but also children to explore their potential, talents, and dreams. The approach, therefore, should be applied in the TVET system, as well as in the general education system at all levels in the country.

\subsection{Applying the capability approach in education: A policy option?}

In previous sections, I have highlighted that the current policy, interventions and education approach have faced several challenges to ensuring that individual youths realise their potential and aspirations. Additionally, as explained in chapter 6 , the social, cultural, and economic factors have limited the ability of rural youth to achieve their dreams. This means that widening education participation is needed, especially in the context of TVET. Such expansion requires the involvement of various stakeholders-families, communities, institutions, and society.

My attempt in this section is to seek out possibilities that help youth, or more generally students at all levels of education, realise their potential and aspirations. It may be that Laos needs to include the capability approach into their education policy, programmes, and activities. Before explaining how such an approach is 
beneficial, and based on the data presented in chapter 6, I first map out the aspirations of youth into capability elements to show the relationships between them (Table 7.1).

Table 7.1 Capability approach and education

\begin{tabular}{|c|c|c|}
\hline \multirow{2}{*}{$\begin{array}{l}\text { Elements of } \\
\text { capability }\end{array}$} & \multicolumn{2}{|c|}{ Aspirations of youth in relation to the capability approach } \\
\hline & $\begin{array}{l}\text { Required capabilities } \\
\text { (skills and resources) }\end{array}$ & $\begin{array}{l}\text { Required human functionings (aspiring } \\
\text { for being and to doing) }\end{array}$ \\
\hline $\begin{array}{l}\text { (a) education } \\
\text { for } \\
\text { achieving } \\
\text { human basic } \\
\text { needs }\end{array}$ & $\begin{array}{ll}\text { 1. } & \text { Relevant skills } \\
\text { and knowledge } \\
\text { 2. } & \text { Financial support }\end{array}$ & $\begin{array}{l}\text { 1. Rural-urban migration to allow } \\
\text { higher education, earnings and more } \\
\text { comfortable lifestyle } \\
\text { 2. Become qualified technicians and } \\
\text { skilled workers } \\
\text { 3. Attend well-known institutions for } \\
\text { better income and living conditions, } \\
\text { or to gain socio-economic status } \\
\text { (SES) }\end{array}$ \\
\hline $\begin{array}{l}\text { (b) education } \\
\text { for human } \\
\text { well-being }\end{array}$ & $\ldots$ & $\begin{array}{l}\text { 1. High self-commitment and } \\
\text { dedication to one's own family, and } \\
\text { community development } \\
\text { 2. Ambitions, passions, and } \\
\text { perseverance (grit) to bring about } \\
\text { change for one's own family-from } \\
\text { being a deprived family to a better } \\
\text { income-earning, happier family, with } \\
\text { greater well-being } \\
\text { 3. To be well-rounded, physically and } \\
\text { mentally }\end{array}$ \\
\hline $\begin{array}{l}\text { (c) education as } \\
\text { foundational } \\
\text { capacity for } \\
\text { agency and } \\
\text { freedom }\end{array}$ & $\begin{array}{l}\text { 1. Space that } \\
\text { supports } \\
\text { individual youth } \\
\text { development } \\
\text { 2. Enabling business } \\
\text { environments for } \\
\text { youth }\end{array}$ & $\begin{array}{l}\text { 1. Freedom to do things based on } \\
\text { individuals' values (for instance, } \\
\text { own a business) } \\
\text { 2. Contribute to the country's } \\
\text { development and prosperity }\end{array}$ \\
\hline $\begin{array}{l}\text { (d) education as } \\
\text { foundational } \\
\text { capacity for } \\
\text { social } \\
\text { justice }\end{array}$ & $\begin{array}{l}\text { 1. Support from } \\
\text { individuals, } \\
\text { organisations, and } \\
\text { society }\end{array}$ & $\begin{array}{l}\text { 1. The life choices of youth are } \\
\text { respected by family and society }\end{array}$ \\
\hline
\end{tabular}

Source: Author's interpretation and illustration based on data presented in Table 6.2, 6.3, 6.4, and 6.5, and Box 6.1, 6.3 and 6.4 (chapter 6); the format used here is adapted from Wood and Deprez (2012, p. 475)

Table 7.1 shows that the aspirations of youth are diverse which can be classified into four elements of capabilities: (a) education for achieving human 
basic needs; (b) education for human well-being; (c) education as foundational capacity for agency and freedom; (d) education as foundational capacity for social justice. This suggests that there could be advantages in applying the capability approach in education in order to help youth, or learners, achieve their dreams.

A number of scholars have argued for applying the human capability approach in education (Nussbaum, 2006; Sen, 2001; Tikly, 2013; Walker \& Unterhalter, 2007). Walker and Unterhalter (2007, p. 251) state that "the capability approach... allows for polarity in choosing lives we have reason to value. The approach emphasizes the important of capability over functioning - not a single idea of human flourishing, but a range of possibilities and a concern with facilitating valuable choices." Applying such an approach may enable rural youth to exercise their diverse aspirations and values of life.

In the context where marginalised groups exist, applying the capability approach can enhance their capabilities to act upon their education trajectories (Nussbaum, 2006; St. Clair, Kintrea, \& Houston, 2013), expand their livelihood choices and achieve individual goals of poverty reduction (Campbell \& McKendrick, 2017; Conradie \& Robeyns, 2013; Levine, 2004). The approach can also promote social justice (Nussbaum, 2016; Walker \& Unterhalter, 2007). Raising aspirations, or human capabilities, can also increase children's motives to acquire education, thus reducing early school leaving (Hartas, 2016). Raising aspirations can also help raising the pride and confidence among students from deprived family and ethnic backgrounds (Børhaug, 2012).

The capability approach has a critical role in promoting human freedom and livelihood choices, and it is now globally recognised as an important tool for achieving human flourishing. In 2016, for example, the United Nations published their 'latest,' as it is called, Human Development Report, highlighting the essential need to include a human capacities approach into development policy, programmes and activities (UNDP, 2016). Accordingly, the notion of human development may be re-defined as follows:

Human development is about enlarging freedoms so that all human beings can pursue choices that they value. Such freedoms have two fundamental aspects - freedom of well-being, represented by functionings and capabilities, and freedom of agency, represented by voice and autonomy ... Human development focuses on the richness of 
human lives rather than on the richness of economies. (UNDP, 2016, pp. 1-2).

It has been argued that "education is a foundational capacity intrinsically important for human well-being and an enabling capacity for people to live lives they have reason to value" (Sen and Nussbaum, cited in Wood \& Deprez, 2012, p. 471). As McGrath and Powell (2016) also argue, if education, especially TVET, centres human capabilities, it will not only help address poverty, inequality, and injustice issues, but also promote economic and sustainable development. Therefore, it can be useful for Laos to look at the role of education beyond material actualisation, or economic benefits gain.

Supporting the application of the capability approach is the idea of democratic education. As John Dewey argues, "education should not be the pouring of knowledge into a child, but supplying its growth from within. Education must begin by understanding a child's capabilities, interests, habits, and instincts" (Dewey, cited in Sullivan, 1966, p. 392). Taking into account a child's capabilities, interests, habits, and instincts may result in a greater academic performance, as well as professional careers. Crucially, for Robinson (2006, 2011), the focus on an individual's learning interests, culture, experiences, passions and aspirations can promote his/her creativity and innovation which can then put that individual's life on a more successful path. For Robinson (2006), creativity and innovation are fundamental for individuals' growth both in academic and professional life. Thus, education reform that promotes such elements is required. If freedoms are to be enlarged, capabilities enhanced, and human functionings promoted, then incorporating the human capability approach in education, as well as in other development interventions, may be ideal for education development in Laos.

\subsection{Summary}

This chapter has examined the extent to which current TVET policy and interventions respond to livelihoods of youth in rural Laos. It argues that the policy response is inadequate to the needs of rural youth, partly due the influence of national and international development discourse that largely emphasise macroeconomic development, neglecting the needs of people at the grassroots level. Although attempts have been made to improve TVET in several sectors including 
agriculture, industry and service, to reduce rural poverty, more efforts are needed, particularly in the agriculture and tourism sectors. Further attention should be given to the improvement of the TVET subsector by incorporating a human capabilities approach in TVET policy, programmes, and curriculum. Its focus should be aimed at the human development notion that aims to enrich human lives, while still remaining committed to improvements in economic well-being. 
This page intentionally left blank 


\section{Chapter 8 Conclusion}

The central objective of this research was to examine the relevance of vocational education (TVET) to the livelihoods of local people with an emphasis on youth in rural Laos. Its attempt was to provide an insight concerning the issues around education, livelihoods and development among indigenous peoples in the country. The question of relevance was raised and addressed by examining the alignment of current TVET approaches to the current livelihoods and aspirations of young people in rural villages of Laos. The research spelled out what has been done and what needs to be done in order to ensure livelihoods of rural people are improved.

With the help of social constructivism, the sustainable livelihood approach, and qualitative and ethnographic methodologies, the research was able to provide an in-depth analysis from the perspective of people at the grassroots level. It provided a full picture of what local people do to secure livelihoods, how they do it and why. The research was able to present how and why rural youth make their education choices, what their interests are, and their passions and aspirations towards individual economic welfare and well-being. The voices of rural youth raised in this research paint a very powerful picture of people from impoverished family, ethnic minority, or indigenous backgrounds.

The aspirations of rural youth as found in this study challenge the government's current education development initiatives, as well as provide empirical information by which policy development might consider how to take full advantage of youth as capital for future nation-building, growth, and prosperity. The study of rural youth aspiration provides room for further debate in education policy development at the national and international levels. The challenges may be to consider how the diverse aspirations of people can be translated into development policy, and what mechanism is needed to measure people's aspirations. These challenges have also been raised by some scholars and researchers (Conradie \& Robeyns, 2013; Duckworth, 2016; Hart, 2013). 
This chapter proceeds as follows. First, it recaps the findings and discussions in this research showing the linkages between TVET, rural livelihoods, and development. Then it presents areas for further expansion of TVET in order to meet desirable development outcomes. Finally, it explains the contributions of this research to development policy and practice, as well as the limitations of the research, and areas for further investigation.

\subsection{Linkages between TVET, rural livelihoods and development}

In this research, I have argued that TVET has a significant role to play in rural livelihood improvement, poverty reduction and economic growth in Laos, currently a Least Developed Country according to the UN. Since 2007, the Lao government has attempted to widen access and participation, in order to improve the quality and relevance, and to strengthen the governance and management, of TVET. With the technical and financial support of the development partners, several TVET policy reforms have been initiated. A major area of the reform is the policy shift from a supply-driven to a demand-driven approach. The approach aims at matching the supply of TVET to the demand of the labour market. Rural youth have been encouraged to attend TVET so they will be equipped with skills that are required in the market economy.

These attempts, however, have not fully met the demands of national and local development in the country until recently. At the national level, the labour shortage is still an issue. At the local level, the expansion of TVET is uneven. Insufficiency of finance, low levels of human resource capacity, poor infrastructure, and low reputation and recognition of TVET have constrained the expansion and development of TVET in Laos.

This research found that the low level of TVET recognition is linked to the society's misconception of TVET, believing that its skills will lead to low-paid work, and that TVET-related work is regarded as the work of society's lower-class. The majority of people in the country hold the premise that TVET will not provide 'good work' (white collar-work) for them. Addressing these challenges are the government's current priorities.

Research findings also reveal that communities in rural areas face several challenges to securing livelihoods. Most rural people have low human capital. As a 
result, they continue working in unproductive farms, making it difficult for them to escape from the vicious cycle of poverty. Moreover, low human capital and technological advance leads most of them to rely on traditional knowledge and techniques for farming. Consequently, they cannot produce a surplus for sale. Exchange of goods and access to markets and finance are uneven. Moreover, agricultural land areas in many parts of rural Laos are squeezing. Development projects sometimes threaten existing livelihoods. The government's economic development policy sometimes degrades indigenous peoples' culture and livelihood systems.

It seems that livelihood adaptive capabilities and strategies employed by each ethnic group differs, depending on their available capitals, such as natural capital, human capital, and economic capital. In a place where resources are rich, livelihood choices and business opportunities are larger. This sits in contrast to places where resources are scarce. There are signs of livelihood and social change in some rural villages of Laos. Some households have shifted from farm to non-farm livelihoods. However, others remain working on farms. Life in rural areas is getting more and more difficult. Rural-urban migration in search of higher education and jobs has, therefore, become a new livelihood strategy for many rural households and individual youth.

TVET alone cannot resolve all the challenges facing rural communities in Laos. However, it can help improve their human capital and capabilities, as well as offering very relevant skills to enhance their livelihoods. Two TVET institutions I visited in Luang Prabang, for example, provide several programmes related to tourism, upland agriculture and basic business. These skills are essential to improve the existing livelihood systems (rural tourism and upland agriculture) in the two study villages. Basic business skills can, presumably, help people get access to finance and manage it effectively. They will also know how to generate more income, increase savings, and allocate the budget for investment. As reported by rural youth who have enrolled in TVET, the knowledge and skills they obtain will help them get jobs, or start their own business. If more youth from rural areas are enrolled in TVET, then their livelihoods will be improved.

Unfortunately, few youths from rural and remote areas were enrolled in TVET. Traditional beliefs, gender norms, and economic deprivation seem to be the most frequent constraints preventing rural youth from having equitable access to 
education, limiting their opportunity to enjoy the socio-economic welfare in the country as a result. The government and its development partners have initiated some TVET programmes, for instance, the scholarship schemes, to reach these youths. These initiatives, however, are at the very early stage, and funding, especially for indigenous development activities, is very limited. More investment in TVET is, therefore, ideal.

This research has found that rural youth with high aspirations are more likely to overcome several challenges to education. A number of rural youth who had enrolled in TVET, for example, were mainly there due to the power of their own passion, perseverance, persistence, and ambition about their educational and career pathways. As life in rural Laos is hard, some youth want to continue living in the cities and work after their graduation. While some plan to live permanently and bring their parents to stay with them, others consider living in the cities as temporary. There are youth who do not want to move to cities as their sense of connection to their places of origin-connected in turn to social cohesion and culture - is high.

To what extent have TVET policy and interventions responded to this diversity of aspirations? In this research, I have argued that the current TVET response is inadequate. This is partly because TVET is used narrowly as an instrument to foster economic development. TVET can promote the development of agricultural, industrial, and service sectors. And, improving these sectors is deemed likely to transform the country into a modern and industrialised nation in both the short-term and long-term. However, as TVET centres too much on economic development, it neglects a sense of human development. The economicbased development approach seems to be a result of the influence of aid donors, national socio-economic development plans, and political directions.

This research also reveals that the current volume of investment in TVET is very limited, especially in agricultural education. The expansion of TVET is, therefore, highly needed, if economic growth and poverty reduction are to be promoted. 


\subsection{Areas for further expansion of TVET}

This research revealed that the livelihood aspirations of youth are diverse. They can be classified into at least four elements: aspirations for achieving human basic needs (higher education and migration for future careers), well-being, self-agency and freedom, and social justice. Their aspirations look beyond economic well-being which is opposed to current approaches and interventions. Although MOES has introduced a student-centred education approach as a means to promote the critical thinking, creativity, imagination, and innovation of youth, such an approach has not yet been successfully implemented in many schools. Worse, the approach has not yet been applied in most TVET institutions. Expansion of this approach is essential.

In building on the existing education approach, I have proposed applying human capabilities to the Lao education system. Along with this approach, democratic education can become a useful tool and can be well-incorporated into student-centred education. A key advantage of the human capabilities approach is that it can enhance the wider richness of human beings, rather than solely target improved economic well-being (McGrath \& Powell, 2016; Powell \& McGrath, 2014; Tikly, 2013). If TVET can offer support beyond encouraging only economic development by considering human beings as central to development, youth may be able to achieve what they aspire for-what they want to do and be. In fact, a similar suggestion has been made in the current human development report on Laos. It states that education should not only raise "people's employability," but should also open "the doors to greater incomes, choices and freedom" (MPI \& UNDP, 2017, p. 16). Integrating a human capabilities approach in education is, therefore, essential for greater development outcomes in the country.

Another area that TVET may need to expand is the inclusion of more ethnic minority groups and their voices. I have argued that these population groups are the most vulnerable in terms of their economic welfare. Their rights to education and development must be promoted (United Nations, 2007, 2012); thus, the goal of 'no one left behind' can possibly be met (ILO, 2016a; United Nations, 2015b). Importantly, integrating indigenous knowledge into TVET policy and programmes can be useful. Acknowledging indigenous knowledge in TVET policy and practice may lead to sustainability of development. 


\subsection{Research contribution}

Results of this research contribute significantly to the current policy debate and practice within aspects of TVET, livelihoods and development in Laos. The research provides rich ethnographic evidence that enhances policy-makers' understanding of the educational perceptions and aspirations of rural youth in pursuit of their own needs and well-being. These findings can contribute to programme design and planning in the country. Areas for further consideration provided in this research can encourage an in-country policy dialogue in the near future.

Within the international development discipline, this research contributes significantly to the debate around the global shift of TVET policy and its challenges in practice. Findings and discussions within indigenous peoples, education and development provide additional evidence concerning the development challenges of indigenous peoples in a Least Developed Country like Laos. The research also informs the significance of the sustainable livelihoods approach. The study of rural youth aspiration recounts the importance of capabilities in TVET, and more broadly in human development programmes (Tikly, 2013; UNDP, 2016). This further informs some of the arguments that development should be about promoting individuals' freedom, or seeing development as freedom (Sen, 2001).

More importantly, the research is very successful in moving and integrating different scales from a particular development issue. The analysis and discussion of very personal, individual cases and experiences, and then comparing and contrasting them to the existing development processes and policies at the regional and national levels have provided insights into how the different elements of education, TVET, livelihoods, and development are related. Looking at their relationships from various angles (such as livelihood, human capital, and human capacities approaches) across scales (local, regional, and national levels) has contributed significantly to the argument that the education-development relationship is still a contested idea (McGrath \& Gu, 2016).

\subsection{Research limitation and areas for further exploration}

Although this research was successfully conducted, I encountered some constraints and limitations. The body of literature in the field of vocational education in Laos 
is small. Partly, this is due to the engagement of TVET in the country's socioeconomic development policy and because practice is relatively new. Access to online information was also limited. For instance, the Ministry of Agriculture and Forestry has no website for agricultural and vocational education. These factors limited my understanding of the context, preventing me from making some arguments explicit.

Also, more time doing the fieldwork could have allowed a deeper understanding of the people's culture, lives and experiences. However, as a Masters student, I have limited timeframes.

Through this research, I can identify at least four areas that need further exploration. First, an assessment of the relevance of the application of the demanddriven approach in TVET in Laos is needed. Results of such research can inform education development policy and practice.

Second, as Laos is in its early stage of TVET reform, comparative education policy research can be very useful. Although I have spelled out areas where Laos can learn from other countries, the information provided is limited. More research on the role of TVET in supporting development with an emphasis on neoliberalism (e.g., modernisation, industrialisation, privatisation, and market-oriented economy) will provide insights for the Lao government, and other Least Developed Countries.

Third, although I have argued to include a human capabilities approach in education in Laos, larger scale research on this matter would contribute significantly to policy debate at the national and international levels.

Finally, a study on the role of in-formal TVET (IVET) in supporting the informal development sector could be very useful for development policy and practice. Out-of-school youth, as mentioned in this research, may receive direct benefits from informal TVET as opposed to the formal one.

\subsection{In closing}

At the heart of this thesis is an assessment of the relationship between education and development. As I have followed this line, I have tried to connect some of the key elements to unpack their connections, tensions, possibilities, and limitations, aiming to provide food for thought for further considerations on the complex, multifaceted implications of education policies in the lives, dreams, livelihoods and 
cultures of real people. I have shown that the relationships between the elements in this research are complex and multi-scalar, including from the economic and TVET reforms to cultural norms, family history and personal aspirations.

The complexity of the education-development relationship explained in this research, including its multi-scale nature, suggests a need to search for development alternatives that are more appropriate and inclusive, while respecting and celebrating the differences and freedom of individuals (Rapley, 2008). The alternatives call for the resurrection of indigenous knowledge across scales. Indigenous knowledge, voices and priorities must be viewed as important assets in development, rather than marginalised and dominated by Western epistemology and the production of scientific knowledge (Agrawal, 1995; Breidlid, 2013). Indigenous knowledge must be regarded as a significant source for development as it offers more effective development strategies and outcomes (Briggs \& Sharp, 2004). As such, greater autonomy must also be given to indigenous peoples, if a more sustainable way of achieving and maintaining development is to be promoted (Agrawal, 1995).

As an indigenous (Kmhmu) Masters student conducting research related to indigenous peoples, their education and development, as well as engaging with a massive body of literature, have been an invaluable learning process for me. I have learned to be more critical, sceptical, and rigorous about what I have read, what information I need to present in this research, and why it is necessary. Some of my critical reflection in relation to what conducting such research means for me are as follows.

Writing entails not only much reading, but it also involves a lot of effort and a lot of thinking.

Writing is not simply a process of replicating what you have read, but it is the process of creating new arguments.

Writing is not only about presenting facts, but it is also about making sense and meanings of out the facts.

Doing research is a self-educating and self-learning process. When we learn, we do not only acquire knowledge, but we also question the knowledge $e^{18}$.

\footnotetext{
${ }^{18}$ The last sentence is quoted from John Overton in his opening speech during "New Zealand Aid Scholarships Completion Ceremony" on the $9^{\text {th }}$ March 2017.
} 
In search of knowledge, we do not only search for existing realities and truths, but we also look for new potentials, possibilities and options.

I have enjoyed my journey, and value the knowledge I have gained throughout this research. I have been inspired by this Masters thesis to pursue higher education. I have been inspired by its findings to conduct further research, perhaps at Ph.D. level. I want to examine existing development discourses in a country like Laos-one that has been heavily influenced by Marxism and its impacts on the livelihoods of rural people and the wider cultural change they have experienced. I am convinced that I should write a book entitled (something like): A short development history in Laos: Insights from a livelihood perspective.

All in all, I want to help raise the voices and rights of indigenous peoples, and those of people in all walks of life. I want to be a part of reducing the gap between inequality and injustice in society. I want to help tackle the idea of discrimination and division between 'us' and 'them,' and between 'the powerful' and 'the powerless.' Among the indigenous or the powerless, I want to help promote and celebrate the diversity of their culture, assert the freedom of their life choices, and help realise their dreams and aspirations in pursuit of human flourishing and wellbeing. 
This page intentionally left blank 


\section{References}

ADB. (2010a). Lao People's Democratic Republic: Strengthening Technical and Vocational Education and Training Project. Vientiane: Asian Development Bank (ADB). Retrieved from https://www.adb.org/sites/default/files/projectdocument/63501/42278-02-lao-pam.pdf.

ADB. (2010b). Proposed Grant: Lao People's Democratic Republic: Strengthening Technical and Vocational Education and Training Project. Vientiane: Asian Development Bank (ADB). Retrieved from https://www.adb.org/sites/default/files/project-document/63502/42278-02-laorrp.pdf.

ADB. (2010c). Public-Private Partnerships in ADB Education Lending, 2000-2009. The Philippines: Asian Development Bank (ADB). Retrieved from https://www.adb.org/sites/default/files/publication/27484/ppp-education-20002009.pdf.

ADB. (2017). Asian development outlook 2017: Transcending the middle-income challenge. Philippines: Asian Development Bank (ADB). Retrieved from https://www.adb.org/sites/default/files/publication/237761/ado-2017.pdf.

Agrawal, A. (1995). Dismantling the divide between indigenous and scientific knowledge. Development and Change, 26(3), 413-439.

Alexander, K. S., Millar, J., \& Lipscombe, N. (2010). Sustainable development in the uplands of Lao PDR. Sustainable Development, 18(1), 62-70.

Alkire, S. (2002). Dimensions of human development. World Development, 30(2), 181205.

Almeida, R., Behrman, J., \& Robalino, D. (Eds.). (2012). Human development perspectives: The Right Skills for the Job? Rethinking Training Policies for Workers. Washington: World Bank Publications.

Ames, R. T., \& Hershock, P. D. (2008). Educations and their purposes: A conversation among cultures. Honolulu: University of Hawaii.

Anand, S., \& Sen, A. (1997). Concepts or human development and poverty: A multidimensional perspective. United Nations Development Programme, Poverty and human development: Human development papers, 1-20.

Applefield, J. M., Huber, R., \& Moallem, M. (2000). Constructivism in theory and practice: Toward a better understanding. The High School Journal, 84(2), 35-53.

Arbuthnott, K. D. (2009). Education for sustainable development beyond attitude change. International Journal of Sustainability in Higher Education, 10(2), 152-163.

Arndt, D. (1992). Foreign Assistance and Economic Policies in Laos, 1976-1986. Contemporary Southeast Asia, 14(2), 188-210.

Arthur-Mensah, N., \& Alagaraja, M. (2013). Exploring technical vocational education and training systems in emerging markets: A case study on Ghana. European Journal of Training and Development, 37(9), 835-850.

Ashley, C., \& Maxwell, S. (2001). Rethinking rural development. Development policy review, 19(4), 395-425.

AusAID. (2012). Australia Laos rural development delivery strategy 2012-16. Vientiane: AusAID. Retrieved from https://dfat.gov.au/about-us/publications/Documents/laosrural-development-strategy.pdf.

Australian National University. (2012). Laos with province borders and names and provincial capitals. Retrieved March 25, 2017, from CartoGIS, College of Asia 
and the Pacific, the Australian National University

http://asiapacific.anu.edu.au/mapsonline/base-maps/laos-base

Australian National University. (n.d.). Major towns, roads and rivers of Laos. Retrieved March 14, 2017, from CartoGIS, College of Asia and the Pacific, the Australian National University http://asiapacific.anu.edu.au/mapsonline/base-maps/laos

Bafoil, F., Diaz, N., Guerin, S., Morris, A., \& Sen, S. (2016). Developing dependency: SEZ in the Greater Mekong Sub-Region: A comparative perspective. Retrieved from http://www.sciencespo.fr/coesionet/sites/default/files/GMS\%20Capstone\%20Repor t\%20May\%2017.pdf

Bailey, R., Barrow, R., Carr, D., \& McCarthy, C. (Eds.). (2010). The Sage handbook of philosophy of education. London: Sage.

Becker, G. S. (2009). Human capital: A theoretical and empirical analysis, with special reference to education (3rd ed.). Chicago: The University of Chicago Press.

Biesta, G. (2006). Beyond learning: Democratic education for a human future. Boulder: Paradigm Publishers.

Biesta, G. (2013). The beautiful risk of education. Boulder: Paradigm Publishers.

Blair, M. (2011). An economic perspective on the notion of human capital. In A. BurtonJones \& J. C. Spender (Eds.), The Oxford Handbook of Human Capital. New York: Oxford University Press.

Børhaug, F. B. (2012). Rethinking anti-racist education in the light of the capability approach. Journal of Human Development and Capabilities, 13(3), 397-413.

Bourgeois Lüthi, N., \& Phangphongphakdy, P. (2014). Assessment of credit possibilities for graduates from the Northern Agriculture and Forestry College (NAFC) and other Agriculture and Forestry Colleges under the Ministry of Agriculture and Forestry $(M A F)$. Helvetas Swiss Intercooperation. Vientiane.

Breidlid, A. (2013). Education, indigenous knowledges, and development in the global south: Contesting knowledges for a sustainable future. London: Routledge.

Briggs, J., \& Sharp, J. (2004). Indigenous Knowledges and Development: A Postcolonial Caution. Third World Quarterly, 25(4), 661-676.

Buckler, C. (2014). Shaping the Future We Want: UN Decade of Education for Sustainable Development (2005-2014). Paris: UNESCO. Retrieved from http://unesdoc.unesco.org/images/0023/002301/230171e.pdf.

Burr, V. (2015). Social Constructionism. New York: Routledge.

Campbell, L. A., \& McKendrick, J. H. (2017). Beyond aspirations: Deploying the capability approach to tackle the under-representation in higher education of young people from deprived communities. Studies in Continuing Education, 39(2), 120137.

Carney, D. (1999). Approaches to sustainable livelihoods for the rural poor. London: Overseas Development Institute.

Cavanagh, D., Shaw, G., \& Wang, L. (2013). Technical and vocational education and training, and skills development for rural transformation. In UNESCO-UNEVOC (Ed.), Revisiting global trends in TVET: Reflections on theory and practice (pp. 309-335). Bonn, Germany: UNESCO-UNEVOC International Centre for Technical and Vocational Education and Training.

Chacko, E. (2004). Positionality and praxis: Fieldwork experiences in rural India. Singapore Journal of Tropical Geography, 25(1), 51-63.

Chambers, R. (1983). Rural development: Putting the last first. New York: Wiley.

Chambers, R., \& Conway, G. (1992). Sustainable rural livelihoods: Practical concepts for the 21st century. Institute of Development Studies. Retrieved from https://opendocs.ids.ac.uk/opendocs/bitstream/handle/123456789/775/Dp296.pdf?s equence $=1 \&$ isAllowed $=y$.

Chounlamany, K. (2014). School education reform in Lao PDR: Good intentions and tensions? Revue internationale d'éducation de Sèvres [Online]. 
Conradie, I., \& Robeyns, I. (2013). Aspirations and human development interventions. Journal of Human Development and Capabilities, 14(4), 559-580.

Coulombe, H., Epprecht, M., Pimhidzai, O., \& Sisoulath, V. (2016). Where are the poor? Lao PDR 2015 Census-based poverty map: Province and district level results. Vientiane: Lao Statistics Bureau, Ministry of Planning and Investment. Retrieved from http://documents.worldbank.org/curated/en/477381468415961977/pdf/106899WP-P146141-PUBLIC.pdf.

Craig, D., \& Porter, D. (2003). Poverty Reduction Strategy Papers: A new convergence. World Development, 31(1), 53-69.

Crang, M., \& Cook, I. (2007). Doing ethnographies. London: Sage.

Cremin, P., \& Nakabugo, M. G. (2012). Education, development and poverty reduction: A literature critique. International Journal of Educational Development, 32(4), 499-506.

Creswell, J. W. (2014). Research design: Qualitative, quantitative, and mixed methods approaches. London: Sage publications.

Curren, R. R. (Ed.) (2003). A companion to the philosophy of education. Malden, MA: Blackwell.

DALaM. (2010). Survey report on land and forest allocation: Phonxai district, Luang Prabang Province. Department of Agricultural Land Management (DALaM), Ministry of Agriculture and Forestry (MAF). Unpublished work.

Desai, V., \& Potter, R. B. (2014). The companion to development studies (3rd ed.). Abingdon: Routledge.

Detel, W. (2015). Social constructivism. In J. Wright (Ed.), International Encyclopedia of the Social \& Behavioral Sciences (pp. 228-234). Oxford: Elsevier.

Dewey, J. (1963). Democracy and education: An introduction to the philosophy of education. New York: Macmillan.

DIC. (2017). Round Table Process. Retrieved April 24, from The Department of International Cooperation (DIC), Ministry of Planning and Investment (MPI) http://rtm.org.la/about/round-table-process/

Duckworth, A. (2016). Grit: The power of passion and perseverance. New York: Scribner.

Duckworth, A., \& Eskreis-Winkler, L. (2015). Grit (2nd ed.). Oxford: Elsevier.

Duckworth, A., \& Gross, J. (2014). Self-control and grit: Related but separable determinants of success. Current Directions in Psychological Science, 23(5), 319.

Dufour, B., \& Curtis, W. (Eds.). (2011). Studying education: An introduction to the key disciplines in education studies: McGraw-Hill Education (UK).

Education and Sports Magazine. (2017, January 4). Prime Minister stresses to addressing societal misconception on choosing study programmes. Education and Sports Magazine, 1.

Eichhorst, W., Rodriguez-Planas, N., Schmidl, R., \& Zimmermann, K. (2012). A roadmap to vocational education and training systems around the world. Bonn: IZA. Retrieved from http://ftp.iza.org/dp7110.pdf.

Eichhorst, W., Rodríguez-Planas, N., Schmidl, R., \& Zimmermann, K. F. (2015). A road map to vocational education and training in industrialized countries. ILR Review, 68(2), 314-337.

Elliott, J. A. (2006). An introduction to sustainable development (3rd ed.). New York: Routledge.

Elliott, J. A. (2013). An introduction to sustainable development (4th ed.). New York: Routledge.

Ellis, F. (2000). Rural livelihoods and diversity in developing countries. New York: Oxford university press.

Ellis, F., \& Biggs, S. (2001). Evolving themes in rural development 1950s-2000s. Development policy review, 19(4), 437-448. 
Engvall, A. (2006). Ethnic minorities and rural poverty in Lao PDR. Retrieved from http://citeseerx.ist.psu.edu/viewdoc/download?doi=10.1.1.584.1795\&rep=rep1\&ty $\mathrm{pe}=\mathrm{pdf}$

Epprecht, M., Minot, N., Dewina, R., Messerli, P., \& Heinimann, A. (2008). The geography of poverty and inequality in the Lao PDR. Bern: Geographica Bernensia: Swiss National Center of Competence in Research (NCCR) NorthSouth, University of Bern, and International Food Policy Research Institute (IFPRI). Retrieved from http://www.laoatlas.net/links/PDF/The\%20Geography\%20of\%20Poverty\%20and\% 20Inequality\%20in\%20the\%20Lao\%20PDR.pdf.

Erni, C. (2008). The concept of Indigenous Peoples in Asia: A resource book. Chiang Mai, Thailand: International Work Group for Indigenous Affairs (IWGIA) and Asia Indigenous Peoples Pact (AIPP).

Erni, C. (2015). Shifting cultivation, livelihood and food security: New and old challenges for indigenous peoples in Asia. Bangkok, Thailand: The Food and Agriculture Organization of the United Nations; International Work Group For Indigenous Affairs; and Asia Indigenous Peoples Pact. Retrieved from http://www.fao.org/publications/card/en/c/8a0ee1bf-0285-45fb-bf66fd9f1f518f60/.

Escobar, A. (2000). Beyond the Search for a Paradigm? Post-Development and beyond. Development, 43(4), 11-14.

Evans, G. (2002). A short history of Laos: The land in between. Crows Nest NSW, Australia: Allen \& Unwin.

Eversole, R., McNeish, J.-A., \& Cimadamore, A. D. (2005). Indigenous peoples and poverty: An international perspective. London: Zed Books.

Faming, M. (2007). Schooling in the Lao People's Democratic Republic. In G. A. Postiglione \& J. Tan (Eds.), Going to school in East Asia: Greenwood Publishing Group.

Fien, J., Maclean, R., \& Park, M.-G. (2009). Work, learning and sustainable development: Opportunities and challenges (Vol. 8). Netherlands: Springer.

Fife, W. (2005). Doing fieldwork: Ethnographic methods for research in developing countries and beyond. New York: Palgrave Macmillan.

Freeman, N. J. (2001). Laos: Timid transition. In J. Funston (Ed.), Government \& Politics in Southeast Asia. Singapore: Institute of Southeast Asian Studies.

Fujita, Y. (2006). Understanding the history of change in Laos: An important premise for development efforts. Mountain Research and Development, 26(3), 197-199.

Garrison, J., Neubert, S., \& Reich, K. (2012). John Dewey's philosophy of education: An introduction and recontextualization for our times. New York: Springer.

Gergen, K. J. (2013). Social construction in psychology. In A. L. C. Runehov \& L. Oviedo (Eds.), Encyclopedia of Sciences and Religions (pp. 2158-2164). Dordrecht: Springer.

Gerner, M. (2013). Lead agency: UNESCO's global leadership and co-ordination role for the United Nations Decade of Education for Sustainable Development (20052014). Frankfurt am Main, Germany: Peter Lang GmbH.

Gibson-Graham, J. K. (2005). Surplus possibilities: Postdevelopment and community economies. Singapore Journal of Tropical Geography, 26(1), 4-26.

Gilbert, N. (2006). From postgraduate to social scientist: A guide to key skills. London: Sage Publications.

GIZ. (2014). Vocational Education in Laos (VELA). Retrieved from https://www.giz.de/en/downloads/giz2014-en-vocational-education-laos.pdf

GIZ. (2016a). Economic development and employment promotion (EDEP) Program: Vocational education in Lao PDR (VELA). Deutsche Gesellschaft für Internationale Zusammenarbeit (GIZ) GmbH. Bonn and Eschborn, Germany: Unpublished. 
GIZ. (2016b). Vocational Education in Laos (VELA). Deutsche Gesellschaft für Internationale Zusammenarbeit (GIZ) GmbH. Bonn and Eschborn, Germany: Unpublished.

GMS Secretariat. (2016). The Role of Special Economic Zones in improving effectiveness of GMS economic corridors. Greater Mekong Subregion (GMS), Asian Development Bank (ADB). Retrieved from https://www.adb.org/sites/default/files/institutional-document/214316/role-sezgms.pdf.

Gobo, G. (2008). Doing ethnography. London: Sage Publications.

Gonczi, A., \& Hager, P. (2010). The competency model. In P. Peterson, E. Baker, \& B. McGaw (Eds.), International Encyclopedia of Education (3rd ed., pp. 403-410): Elsevier.

Gunn, G. (1988). Laos in 1987: Socialist dependence and underdevelopment. ISEAS Yusof Ishak Institute, 135-149.

Hammersley, M., \& Atkinson, P. (2007). Ethnography: Principles in practice. London: Routledge.

Harber, C. (2014). Education and international development: Theory, practice and issues. Oxford: Symposium Books.

Harrison, D., \& Schipani, S. (2007). Lao tourism and poverty alleviation: Communitybased tourism and the private sector. Current Issues in Tourism, 10(2-3), 194-230. doi:10.2167/cit310.0

Hart, C. S. (2013). Aspirations, education, and social justice: Applying Sen and Bourdieu. London: Continuum.

Hartas, D. (2016). Young people's educational aspirations: Psychosocial factors and the home environment. Journal of Youth Studies, 19(9), 1145-1163.

Hatsadong, Douangsila, K., \& Gibson, P. (2006). Rice-based traditions and rituals in the Mekong River Valley. In J. M. Schiller, M. B. Chanpengxay, B. Linguist, \& S. A. Rao (Eds.), Rice in Laos. (pp. 65-77). Los Baños, the Philippines: International Rice Research Institute.

HELVETAS. (2015). Progress report June to October 2015: SURAFCO II (Support to the Reform of the Northern Agriculture \& Forestry College in Laos, Phase II). Luang Prabang: Unpublished work.

Henry, M., Higate, P., \& Sanghera, G. (2009). Positionality and power: The politics of peacekeeping research. International Peacekeeping, 16(4), 467-482.

Hickey, S., \& Mohan, G. (2004). Participation, from tyranny to transformation? Exploring new approaches to participation in development. London: ZED Books.

Higashi, S. (2015). An alternative approach to land and forest management in northern Lao PDR. In C. Erni (Ed.), Shifting cultivation, livelihood and food security: New and old challenges for indigenous peoples in Asia. Bangkok: The Food and Agriculture Organization of the United Nations; International Work Group For Indigenous Affairs; and Asia Indigenous Peoples Pact.

Hilal, S. E. A., Huang, Q., \& Lanzona, L. (2016). Compilation of assessment studies on technical vocational education and training (TVET): Lao People's Democratic Republic, Mongolia, the Philippines, Thailand and Viet Nam. Bangkok, Thailand: International Labour Organization (ILO). Retrieved from http://www.voced.edu.au/content/ngv:72478.

Hull, D. L. (2015). Evolutionary epistemology. In J. Wright (Ed.), International Encyclopedia of the Social \& Behavioral Sciences (2nd ed., pp. 437-440). Oxford: Elsevier.

Hummelsheim, S., \& Baur, M. (2014). The German dual system of initial vocational education and training and its potential for transfer to Asia. PROSPECTS, 44(2), 279-296.

ILO. (2012). Global employment trends 2012: Preventing a deeper jobs crisis. Geneva: International Labour Organization (ILO). Retrieved from 
http://www.ilo.org/wcmsp5/groups/public/---dgreports/---dcomm/---

publ/documents/publication/wcms_171571.pdf.

ILO. (2015). Global employment trends for youth 2015: Scaling up investments in decent jobs for youth. Geneva: International Labour Organization (ILO). Retrieved from

http://www.ilo.org/wcmsp5/groups/public/---dgreports/---dcomm/--publ/documents/publication/wcms 412015.pdf.

ILO. (2016a). Sustainable development goals: Indigenous Peoples in focus. International Labour Organization (ILO). Retrieved from http://www.ilo.org/global/topics/indigenoustribal/publications/WCMS 503715/lang--en/index.htm.

ILO. (2016b). World employment and social outlook 2016: Trends for youth. Geneva: International Labour Organization (ILO). Retrieved from http://www.ilo.org/wcmsp5/groups/public/---dgreports/---dcomm/--publ/documents/publication/wcms_513739.pdf.

ILO. (2017). World employment and social outlook: Trends 2017. Geneva: International Labour Organization (ILO). Retrieved from

http://www.ilo.org/wcmsp5/groups/public/---dgreports/---dcomm/--publ/documents/publication/wcms_541211.pdf.

Ireson, C. J., \& Ireson, W. R. (1991). Ethnicity and development in Laos. Asian Survey, $31(10), 920-937$.

Jagannathan, S. (2013). Skills for inclusive and sustainable growth in developing Asia and the Pacific. In R. Maclean, S. Jagannathan, \& J. Sarvi (Eds.), Skills development for inclusive and sustainable growth in developing Asia-Pacific (pp. 369-380). Dordrecht: Springer.

Jeannine St. Pierre, H. (1996). Coming to terms: Social constructivism. The English Journal, 85(1), 91-92.

Karmel, T. (2010). An overview of vocational education and training. In P. Peterson, E. Baker, \& B. McGaw (Eds.), International Encyclopedia of Education (3rd ed., pp. 229-239): Elsevier.

Kassem, D., Mufti, E., \& Robinson, J. (2006). Education studies: Issues and critical perspectives. Maidenhead, England: Open University Press.

Kemp, M. (2013, October 1). Death of the riverboats. Wetlands.

Khouangvichit, D. (2010). Socio-economic transformation and gender relations in Lao PDR. (Ph.D. dissertation), Department of Social and Economic Geography, Umeå University, Umeå, Sweden. Retrieved from http://www.divaportal.org/smash/get/diva2:318827/FULLTEXT01.pdf

King, E., \& Walle, D. (2012). Laos: Ethnolinguistic diversity and disadvantage. In G. H. Hall \& H. A. Patrinos (Eds.), Indigenous peoples, poverty, \& development (pp. 249-303). Cambridge: Cambridge University Press.

Konepachit, H. (n.d). A brief history of Luang Prabang technical and vocational education and training. Unpublished.

Kumar, R. (2014). Research methodology: A step-by-step guide for beginners (4th ed.). Los Angeles: Sage.

Lao PDR. (1991). The constitution of the Lao People's Democratic Republic. Vientiane: Constitutional Finder. Retrieved from http://confinder.richmond.edu/admin/docs/laos.pdf.

Lao PDR. (2000). Law on education. Vientiane: International Law Project, the Ministry of Foreign Affairs. Retrieved from http://ilp.gov.la/Lao Law/Education law.pdf.

Lao PDR. (2004). National growth and poverty eradication strategy. Vientiane: United Nations Development Programme (UNDP). Retrieved from http://www.undp.org/content/dam/laopdr/docs/Reports\%20and\%20publications/La o\%20PDR\%20-\%20NGPES\%20-\%20Main\%20Document.pdf.

Lao PDR. (2005). Population cencus 2005: Map repository. Retrieved 21 March 2017, from Online-database of the Government of the Lao PDR.

http://www.decide.la/en/repository 
Lao PDR. (2007). Law on education. International Law Project, the Ministry of Foreign Affairs. Retrieved from http://ilp.gov.la/Laws_in_Lao/46.pdf.

Lao PDR. (2010). Decree on Special Economic Zone and Specific Economic Zone in the Lao PDR. Vientiane: World Trade Organisation (WTO). Retrieved from https://www.wto.org/english/thewto e/acc e/lao e/WTACCLAO20A1 LEG 3.pd f.

Lao PDR. (2013). Prime Minister's decree on poverty and development standard (2012 2015). Vientiane: The Government of Lao PDR.

Lao PDR. (2014). Law on technical and vocational education and training (TVET). Vientiane: Ministry of Education and Sports (MOES). Retrieved from http://www.moe.gov.la/tvet/images/phocagallery/PDF/Content\%20of\%20TVE\%20 Law-June\%202014.pdf.

Lao PDR. (2015). Law on education. Vientiane: The National Assembly of the Lao People's Democratic Republic. Retrieved from http://www.na.gov.la/docs/lao/laws/soc_cult/1education_laws28_08_2015.pdf.

Lao PDR. (2016). Vientiane declaration on partnership for effective development cooperation (2016-2025). Vientiane: United Nations in Lao PDR. Retrieved from http://www.la.one.un.org/images/publications/Vientiane-Declaration-IIFinal Signatories-and-Endorsement.pdf.

Lao Statistics Bureau. (2014). Statistical yearbook 2013. Vientiane: Lao Statistics Bureau, Ministry of Planning and Investment. Retrieved from http://www.1sb.gov.la/year/final\%20for\%20print\%20yearbook\%202013.pdf.

Lao Statistics Bureau. (2016). Results of population and housing census 2015. Vientiane: Lao Statistics Bureau, Ministry of Planning and Investment. Retrieved from http://lao.unfpa.org/en/publications/results-population-and-housing-census-2015english-version.

LDA. (2012). Mid-term evaluation: LAO/O20 Strengthening of human resources in the hospitality and tourism industry in Laos. Luxembourg Development Agency (LDA). Retrieved from https://luxdev.lu/files/documents/LAO_020_EI_EN.pdf.

LDA. (2017a). Country booklets: Laos 2017. Luxembourg Development Agency (LDA). Retrieved from https://vte.luxdev.lu/files/documents/LAO_170103_vF.pdf.

LDA. (2017b). LAO/029 Skills for tourism: Human resources development in the tourism and hospitality sector. Retrieved from https://luxdev.lu/en/activities/project/LAO/029

Levine, D. P. (2004). Poverty, capabilities and freedom. Review of Political Economy, 16(1), 101-115.

Lilao, B. (2005). Rural development in Lao PDR: Managing projects for integrated sustainable livelihoods. Chiang Mai, Thailand: Chiang Mai, Thailand: Regional Center for Social Science and Sustainable Development, Faculty of Social Sciences, Chiang Mai University.

Lord, M. (2012). Evaluation of support to Lao PDR's Special Economic Zones (SEZs). Retrieved from https://mpra.ub.unimuenchen.de/61053/1/MPRA_paper_61053.pdf

MacKinnon, A., \& Thepphasoulithone, P. (2014). Educational reform in Laos: A case study. International Journal of Educational Studies, 1(1), 19-34.

Maclean, R., Jagannathan, S., \& Sarvi, J. (Eds.). (2013). Skills development for inclusive and sustainable growth in developing Asia-Pacific (Vol. 19). Dordrecht: Springer.

Madden, R. (2010). Being ethnographic: A guide to the theory and practice of ethnography: Sage Publications.

MAF. (2008). Strategy for Reform in the Agriculture and Forestry Colleges towards 2020 in Lao PDR. Vientiane: Ministry of Agriculture and Forestry (MAF). Retrieved from https://nafcenglish.files.wordpress.com/2016/09/maf-strategy-for-reform-ofagr-forst-colleges-towards-2020-jan-2008-engl.pdf.

Marope, P. T. M., Chakroun, B., \& Holmes, K. P. (2015). Unleashing the potential: Transforming technical and vocational education and training. Paris: United 
Nations Educational, Scientific and Cultural Organization (UNESCO). Retrieved from http://unesdoc.unesco.org/images/0023/002330/233030e.pdf.

Maxwell, S. (2003). Heaven or Hubris: Reflections on the new 'New Poverty Agenda'. Development policy review, 21(1), 5-25.

McComas, W. F. (2014). Constructivism. In W. F. McComas (Ed.), The language of science education: An expanded glossary of key terms and concepts in science teaching and learning (pp. 21-22). Rotterdam: Sense Publishers.

McGrath, S. (2002). Skills for development: A new approach to international cooperation in skills development? Journal of Vocational education and Training, 54(3), 413430.

McGrath, S., \& Gu, Q. (Eds.). (2016). Routledge handbook of international education and development. New York: Routledge.

McGrath, S., \& Powell, L. (2016). Skills for sustainable development: Transforming vocational education and training beyond 2015. International Journal of Educational Development, 50, 12-19.

Menon, J., \& Warr, P. (2013). The Lao economy: Capitalizing on natural resource exports. Asian Development Bank (ADB). Retrieved from

https://www.adb.org/sites/default/files/publication/30138/economics-wp330-laoeconomy.pdf.

Messerli, Peter, Heinimann, A., Epprecht, M., Souksavath, P., Chanthalanouvong, T., \& Minot, N. (2008). Socio-Economic Atlas of the Lao PDR: An analysis based on the 2005 population and housing census. Bern and Vientiane: Geographica Bernensia: Swiss National Center of Competence in Research (NCCR) North-South, University of Bern. Retrieved from

http://www.decide.la/atlas05/links/PDF/Socio Economic\%20Atlas\%20os\%20the\% 20Lao\%20PDR.pdf.

Meynell, P.-J. (2016). Cumulative impact assessment of the Nam Ou hydropower cascade. Retrieved from

http://www.ifc.org/wps/wcm/connect/fc2260804c0ff7058da2afd8bd2c3114/Cumul ative+Impact+Assessment+of+the+Nam+Ou+hydropower+1+PJc.pdf?MOD=AJP ERES

MOE. (2007a). Master Plan for the development of TVET from 2008 until 2015.

Vientiane: Ministry of Education (MOE). Retrieved from

http://planipolis.iiep.unesco.org/upload/Lao\%20PDR/Lao PDR TVET Master pl an 2008-2015.pdf.

MOE. (2007b). Strategic Plan for the development of technical and vocational education and training from 2006 to 2020. Vientiane: Ministry of Education (MOE).

Retrieved from

http://planipolis.iiep.unesco.org/upload/Lao\%20PDR/Lao_PDR_TVET_Strategic_ plan_2006-2020.pdf.

MOES. (2009). Education Sector Development Framework (2009 - 2015). Vientiane:

Ministry of Education and Sports (MOES). Retrieved from

http://moe.gov.la/data/publications/ESDF\%20English\%20version.pdf.

MOES. (2013). Statistics of teachers and students of technical and vocational education institutions in Lao PDR. Vientiane: Technical and Vocational Education and Training Department, Ministry of Education and Sports (MOES). Retrieved from http://www.moe.gov.la/tvet/images/phocagallery/PDF/Full\%20Statistic\%20year\%2 0book\%20 REVISED\%20New\%20-\%20Copy.pdf.

MOES. (2015a). Social marketing strategy and implementation plan. Vientiane: Ministry of Education and Sports (MOES): Unpublished work.

MOES. (2015b). Statistics of teachers and students of technical and vocational education institutions in Lao PDR. Vientiane: Technical and Vocational Education and Training Department, Ministry of Education and Sports (MOES). Retrieved from http://www.moe.gov.la/tvet/images/phocagallery/PDF/Statistics\%20year\%20\%202 013-2015.pdf. 
MOES. (2016). Technical and vocational education and training development plan (2016 - 2020). Vientiane: Ministry of Education and Sports (MOES). Retrieved from http://www.moe.gov.la/tvet/images/phocagallery/PDF/nitikum/TVET\%20Dev\%20 plan\%20English\%20final\%20PPD.pdf.

MOES. (2017). Public TVET institutions under the governance and administration of MOES in Lao PDR. Retrieved from http://www.moe.gov.la/tvet/index.php/201402-19-04-31-36

Morse, S., \& McNamara, N. (2013). Sustainable livelihood approach: A critique of theory and practice. Dordrecht: Springer.

Moser, C. O. (1998). The asset vulnerability framework: Reassessing urban poverty reduction strategies. World Development, 26(1), 1-19.

MPI. (2013). Guidelines: District socio-economic development planning. Ministry of Planning and Investment (MPI). Unpublished work.

MPI, \& JICA. (2010). Manual for public investment program (PIP) program management. Vientiane: Ministry of Planning and Investment (MPI) and Japan International Cooperation Agency (JICA). Retrieved from https://www.jica.go.jp/project/english/laos/0700667/materials/pdf/manual/manual_ program_e1.pdf.

MPI, \& UNDP. (2009). Lao PDR: Employment and livelihoods (The 4th National Human Development Report). Vientiane: Ministry of Planning and Investment, and UNDP. Retrieved from http://hdr.undp.org/sites/default/files/lao nhdr 2009 en.pdf.

MPI, \& UNDP. (2016). 8th Five-Year National Socio-Economic Development Plan (2016-2020). Vientiane: Ministry of Planning and Investment. Retrieved from http://www.la.one.un.org/images/publications/8th_NSEDP_2016-2020.pdf.

MPI, \& UNDP. (2017). The 5th National Human Development Report. Vientiane: Ministry of Planning and Investment (MPI), and United Nations Development Programme (UNDP). Retrieved from http://www.la.undp.org/content/lao_pdr/en/home/library/human_development/the5th-national-human-development-report.html.

Mujahid, G., Laxasy, P., Boutlasy, P., Sengaloun, S., \& Siphaseuth, V. (2011). Internal migration in the Lao People's Democratic Republic: An exploratory study. Department of Planning, Ministry of Planning and Investment (DOP-MPI). Unpublished work.

Mullings, B. (1999). Insider or outsider, both or neither: some dilemmas of interviewing in a cross-cultural setting. Geoforum, 30(4), 337-350.

NAFC. (2014). Northern Agriculture and Forestry College (NAFC)'s prospectus. Retrieved from https://nafcenglish.files.wordpress.com/2016/09/nafcprospectus_english-version_2014-compressed1.pdf

Newmann, F. M. (1985). The radical perspective on social studies: A synthesis and critique. Theory \& Research in Social Education, 13(1), 1-18.

Ngoy RDPRO. (2015). A summary of poverty and development in Ngoy district, Luang Prabang province (2011 - 2015). Rural Development and Poverty Reduction Office of Ngoy district (RDPRO). Unpublished work.

Noonan, R. (2015). Special \& Specific Economic Zones in Lao PDR: Some notes on education and training implications. Retrieved from https://www.academia.edu/8055872/Special and Specific Economic Zones in L ao_PDR_Some_Notes_on_Education_and_Training_Implications_2015-05-29

Noonan, R., \& Noonan, V. (2017). Historical Glossary of Education Development in Lao $P D R$ Vientiane: Samizdat.

Noonan, R., Phommalangsy, P., \& Phetsiriseng, I. (2013). Lao PDR: The great transformation In L. P. Symaco (Ed.), Education in South-East Asia (Vol. 20): A\&C Black.

Nordin, E., \& Öberg, H. (2012). Human resource development in Laos: An explorative study on teachers' opinions about human resource development in the National 
University of Laos. (Bachelor degree), Umeå University. Retrieved from http://www.diva-portal.org/smash/get/diva2:608655/FULLTEXT01.pdf

Nussbaum, M. C. (2006). Education and democratic citizenship: Capabilities and quality education. Journal of human development, 7(3), 385-395.

Nussbaum, M. C. (2016). Introduction: Aspiration and the capabilities List. Journal of Human Development and Capabilities, 17(3), 301-308.

O'Leary, Z. (2007). The social science jargon buster: The key terms you need to know. California: Sage.

Owusu, F. (2009). Livelihoods. In N. Thrift (Ed.), International Encyclopedia of Human Geography (pp. 219-224). Oxford: Elsevier.

Palmer, J. (Ed.) (2001). Fifty modern thinkers on education: From Piaget to the present. London: Routledge.

Palomino-Schalscha, M. (2012). Geographies of tourism and development. In J. Wilson (Ed.), The Routledge handbook of tourism geographies (pp. 187-193). Abingdon: Routledge.

Pettit, J. (2006). Power and pedagogy: Learning for reflective development practice. IDS Bulletin, 37(6), 69-78.

Philasouk, P. (2015). A short history of Ban Meuang Ngoy. Vientiane: Savang Printing Ltd.

Pholsena, V. (2002). Nation/Representation: Ethnic classification and mapping nationhood in contemporary Laos. Asian Ethnicity, 3(2), 175-197.

Phomilay, P. (2012). TVET reform in Lao PDR: Challenges and issues and step forward within 2011-2015. Paper presented at the Third International Congress on Technical and Vocational Education and Training: Transforming TVET: Building skills for work and life, Shanghai.

Phommalangsy, P. (2013). An analysis of the influence of foreign aid on basic education policy in Laos. (Doctoral dissertation), The University of Queensland.

Pieterse, J. N. (1996). My paradigm or yours? Alternative development, postdevelopment, reflexive development. The Hague, Netherlands: Institute of Social Studies.

Pieterse, J. N. (2000). After post-development. Third World Quarterly, 21(2), 175-191.

Pieterse, J. N. (2009). Development theory. London: Sage Publications.

Pillow, W. (2003). Confession, catharsis, or cure? Rethinking the uses of reflexivity as methodological power in qualitative research. International journal of qualitative studies in education, 16(2), 175-196.

Pohoata, G., \& Mocanu, M. (2015). Aspect of the philosophy of education in John Dewey's view. Euromentor Journal, 6(4), 7-17.

Pole, C., \& Morrison, M. (2003). Ethnography for education. Berkshire: Open University Press.

Powell, L. (2012). Reimagining the purpose of VET - Expanding the capability to aspire in South African further education and training students. International Journal of Educational Development, 32(5), 643-653.

Powell, L., \& McGrath, S. (2014). Exploring the value of the capability approach for vocational education and training evaluation: Reflections from South Africa. International Development Policy/Revue Internationale de Politique de Développement(5).

Pring, R. (2007). John Dewey: A philosopher of education for our time? London: Continuum.

Rapley, J. (2008). End of development or age of development? Progress in Development Studies, 8(2), 177-182.

Ratnata, I. W. (2013). Enhancing the image and attractiveness of TVET.TVET@Asia: The Online Journal, Collaboration in TVET(1), 13.

Rigg, J. (1997). Southeast Asia: The human landscape of modernization and development. London: Routledge. 
Rigg, J. (2005). Living with transition in Laos: Market intergration in Southeast Asia. London: Routledge.

Rigg, J. (2006). Forests, marketization, livelihoods and the poor in the Lao PDR. Forests, marketization, livelihoods and the poor in the Lao PDR, 17, 123-133.

Rigg, J. (2009). A Particular Place? Laos and its Incorporation into the Development Mainstream. Environment and Planning A, 41(3), 703-721.

Rigg, J. (2016). Challenging Southeast Asian development: The shadows of success. New York: Routledge.

Robertson, J. E. (2002). Reflexivity redux: A pithy polemic on "Positionality". Anthropological Quarterly, 75(4), 785-792.

Robinson, K. (2006). Do schools kill creativity? : TED.

Robinson, K. (2011). Out of our minds: Learning to be creative. West Sussex: Capstone Publishing Ltd.

Rolleston, C. (2011). Educational access and poverty reduction: The case of Ghana 19912006. International Journal of Educational Development, 31(4), 338-349.

Rose, G. (1997). Situating knowledges: positionality, reflexivities and other tactics. Progress in Human Geography, 21(3), 305.

Sachs, W. (2010). The development dictionary: A guide to knowledge as power (Second ed.). London and New York: Zed Books.

Saeng Outhay, O. (2015). The influence of Non-Governmental Organisations (NGOs) on primary education policy in Laos. (Master thesis), Victoria University of Wellington, Wellington, New Zealand.

Sarabhai, K. V. (2014). ESD and Sustainable Development Goals. Journal of Education for Sustainable Development, 8(1), 1-2.

Schroeter, A. (2015). Tracer study of graduates 2013 and 2014 from the Northern Agriculture and Forestry College (NAFC). Vientiane: Swiss Agency for Development and Cooperation (SDC). Retrieved from http://rightslinklao.org/wpcontent/uploads/downloads/2015/06/Tracerstudy_NAFC_2015_Report__FINAL_Engl_for_print_.pdf.

Scoones, I. (1998). Sustainable rural livelihoods: A framework for analysis. IDS Working Paper(72), 1-22.

SDC. (2009). Support to the reform of the Luang Prabang Agriculture and Forestry College (SURAFCO): Project document Phase 1 (2008 - 2011). Swiss Agency for Development and Cooperation (SDC). Unpublished work.

SDC. (2012). Support to the reform of the Northern Agriculture and Forestry College in Laos (SURAFCO): Project document for Phase 2 (2012 - 2016). Swiss Agency for Development and Cooperation (SDC). Unpublished work.

SDC. (2016). Student dreams and aspirations in agriculture and forestry education - Lao PDR. Retrieved March, 4, from Swiss Cooperation in the Mekong Region http://swisscooperationmekong.org/2016/12/student-dreams-and-aspirations-inagriculture-and-forestry-education-lao-pdr/

SDC. (2017). About SDC. Retrieved from http://swisscooperationmekong.org/aboutswiss-cooperation/

Semone, P. (2012). A case study: Enhancing Laos' tourism sector performance through destination human resource development. Asia Pacific Journal of Tourism Research, 17(2), 164-176.

Sen, A. (2001). Development as freedom. Oxford: Oxford University Press.

Sen, A. (2005). Human rights and capabilities. Journal of human development, 6(2), 151166.

Sengxua, P. (2006). Rice-based traditions and beliefs of the Hmong. In J. M. Schiller, M. B. Chanpengxay, B. Linguist, \& S. A. Rao (Eds.), Rice in Laos. (pp. 107-112). Los Baños, the Philippines: International Rice Research Institute.

Simana, S., \& Preisig, E. (2006). Rice-based traditions and rituals of the Kmhmu. In J. M. Schiller, M. B. Chanpengxay, B. Linguist, \& S. A. Rao (Eds.), Rice in Laos. (pp. 79-104). Los Baños, the Philippines: International Rice Research Institute. 
Slater, R., \& Keoka, K. (2012). Trends in the governance sector of the Lao PDR. Vientiane: Swiss Agency for Development and Cooperation (SDC). Retrieved from https://www.eda.admin.ch/content/dam/deza/en/documents/laender/trends-govsector-lao_EN.pdf.

Smith, E. (2010). Apprenticeships. In P. Peterson, E. Baker, \& B. McGaw (Eds.), International Encyclopedia of Education (Third ed., pp. 312-319): Elsevier.

Snow, D. A. (1980). The disengagement process: A neglected problem in participant observation research. Qualitative Sociology, 3(2), 100-122.

St. Clair, R., Kintrea, K., \& Houston, M. (2013). Silver bullet or red herring? New evidence on the place of aspirations in education. Oxford Review of Education, 39(6), 719-738.

St. John, R. B. (1995). New economic order in Indochina. Asian Affairs, 21(4), 227-240.

St. John, R. B. (1997). End of the beginning: Economic reform in Cambodia, Laos, and Vietnam. Contemporary Southeast Asia, 19(2), 172.

Stasz, C., Drabble, S., Castle-Clarke, S., Ertl, H., Holmes, C., \& Villalba van Dijk, L. (2014). Attractiveness of initial vocational education and training. Luxembourg: European Centre for the Development of Vocational Training (Cedefop). Retrieved from https://www.rand.org/pubs/external_publications/EP50530.html.

Stone, L. (2008). Epistemology. In L. M. Given (Ed.), The Sage Encyclopedia of Qualitative Research Methods (pp. 265-268). Los Angeles, California: Sage Publications.

Stuart-Fox, M. (1986). Laos: Politics, economics, and society. London: Lynne Rienner Publishers.

Stuart-Fox, M. (1997). A history of Laos. Cambridge: Cambridge University Press.

Stuart-Fox, M. (2001). Historical dictionary of Laos (2nd ed.). Lanham: Scarecrow Press.

Stuart-Fox, M. (2007). Laos: Politics in a Single-Party State. Southeast Asian affairs(34), 161-180.

Stuart-Fox, M. (2008). Historical dictionary of Laos (3rd ed.). Lanham: Scarecrow Press.

Sullivan, P. (1966). John Dewey's philosophy of education. The High School Journal, 49(8), 391-397.

Sultana, F. (2007). Reflexivity, positionality and participatory ethics: Negotiating fieldwork dilemmas in international research. ACME, 6(3).

SYNOHYDRO. (2011, April 11). Master Agreement for Nam Ou hydropower project, signed in Vientiane. Retrieved from http://eng.sinohydro.com/index.php? $m=$ content $\& c=i n d e x \& a=$ show $\&$ catid=21\&id= $\underline{49}$

Tarabini, A., \& Jacovkis, J. (2012). The poverty reduction strategy papers: An analysis of a hegemonic link between education and poverty. International Journal of Educational Development, 32(4), 507-516.

Thakran, S. (2015). Education for Sustainable Development. Educational Quest, 6(1), 5560.

Tikly, L. (2013). Reconceptualizing TVET and development: A human capability and social justice approach. In UNESCO-UNEVOC (Ed.), Revisiting global trends in TVET: Reflections on theory and practice (pp. 1-39). Bonn, Germany: UNESCOUNEVOC International Centre for Technical and Vocational Education and Training.

Tilak, J. B. G. (2002). Education and poverty. Journal of human development, 3(2), 191207.

Turner, D. A. (2007). Theory and practice of education. London: Continuum.

UCW. (2014). Understanding children's work and youth employment outcomes in Laos. Rome: Understanding Children's Work (UCW) Programme. Retrieved from http://www.ucwprogramme.org/Pages/bib_details.aspx?id=12333\&Pag=0\&Year=$1 \&$ Country $=116 \&$ Author $=-1$. 
UN-OHRLLS. (2016). Land-locked developing countries: Things to KNOW, Things to $D O$. Office of the High Representative for the Least Developed Countries, Landlocked Developing Countries and Small Island Developing States (UN-OHRLLS). Retrieved from http://unohrlls.org/customcontent/uploads/2016/12/LLDC Things To Know-Do 2016.pdf.

UNDP. (2015). Lao PDR Country Analysis Report: Analysis to inform the Lao People's Democratic Republic - United Nations Partnership Framework (2017-2021). Vientiane: The United Nations in Lao PDR. Retrieved from http://www.la.undp.org/content/lao_pdr/en/home/library/mdg/country-analysisreport.html.

UNDP. (2016). Human Development Report 2016: Human development for everyone. New York: United Nations Development Programme (UNDP). Retrieved from http://hdr.undp.org/sites/default/files/2016 human_development_report.pdf.

UNESCO-UNEVOC. (2012). Transforming TVET: From idea to action. Bonn, Germany: UNESCO-UNEVOC International Centre for Technical and Vocational Education and Training (UNESCO-UNEVOC). Retrieved from http://www.unevoc.unesco.org/fileadmin/user_upload/docs/Transforming_TVET_ From_idea_to_action.pdf.

UNESCO. (2001). Education for rural transformation: Towards a policy framework. Baoding, China: UNESCO International Research and Training Centre for Rural Education (INRULED). Retrieved from http://unesdoc.unesco.org/images/0013/001359/135913eo.pdf.

UNESCO. (2013). Policy review of TVET in Lao PDR. Paris, France: The United Nations Educational, Scientific and Cultural Organization (UNESCO). Retrieved from http://unesdoc.unesco.org/images/0022/002211/221146E.pdf.

United Nations. (2007). Resolution adopted by the General Assembly: United Nations Declaration on the Rights of Indigenous Peoples. United Nations. Retrieved from http://www.un.org/esa/socdev/unpfii/documents/DRIPS_en.pdf.

United Nations. (2012). Resolution adopted by the General Assembly: The future we want. Retrieved from https://www.un.org/en/ga/search/view_doc.asp?symbol=A/RES/66/288.

United Nations. (2015a). Lao People's Democratic Republic: Ratio of girls to boys in primary, secondary and tertiary education. from Statistics Division, United Nations http://unstats.un.org/unsd/mdg/Data.aspx

United Nations. (2015b). Transforming our world: The 2030 Agenda for sustainable development. Retrieved from http://www.un.org/ga/search/view doc.asp?symbol=A/RES/70/1\&Lang=E

Walker, M., \& Unterhalter, E. (2007). Amartya Sen's capability approach and social justice in education. New York: Palgrave Macmillan.

Williams, J. H. (2005). Policy-making for education reform in developing countries: Contexts and processes, Volume 1. Lanham, Md.: Scarecrow Education.

Wood, D., \& Deprez, L. S. (2012). Teaching for human well-being: Curricular implications for the capability approach. Journal of Human Development and Capabilities, 13(3), 471-493.

World Bank. (1979). Socialist transformation in the Lao People's Democratic Republic: An economic report. Retrieved from http://documents.worldbank.org/curated/en/704561468300562972/pdf/multipage.pdf

World Bank. (1996). Memorandom and recommendation of the president of the International Development Association to the executive directors on a country assistance strategy of the World Bank Group for the Lao People's Democratic Republic. Retrieved from http://documents.worldbank.org/curated/en/530211468300563593/pdf/multipage.pdf 
World Bank. (2005a). Ethnic groups, gender, and poverty eradication: case study from Khmou Lue community in Oudomxay Province. Retrieved from http://documents.worldbank.org/curated/en/230821468277468143/pdf/348360LA0 gender1and1em11.pdf

World Bank. (2005b). International Development Association: Country assistance strategy for the Lao People's Democratic Republic (Lao PDR). Retrieved from http://documents.worldbank.org/curated/en/9560314682774655435/pdf/317581init0 pdf.pdf

World Bank. (2013). Lao PDR - Skills for quality jobs and development in Lao PDR: A technical assessment of the current context. Retrieved from http://documents.worldbank.org/curated/en/659981468045564160/pdf/ACS65930 WP0P12550200Box382165B00OUO090.pdf

World Bank. (2014a). Lao development report 2014: Expanding productive employment for broad-based growth. Retrieved from http://documents.worldbank.org/curated/en/319261468272103221/Laodevelopment-report-2014

World Bank. (2014b). Lao People's Democratic Republic: Country partnership strategy progress report for the period FY12-16. Retrieved from http://documents.worldbank.org/curated/en/644931468088478994/Lao-PeoplesDemocratic-Republic-Country-partnership-strategy-progress-report-for-the-periodFY12-16

World Bank. (2015). Lao PDR poverty policy notes: Drivers of poverty reduction in Lao $P D R$. Retrieved from http://documents.worldbank.org/curated/en/590861467722637341/Lao-PDRpoverty-policy-notes-drivers-of-poverty-reduction-in-Lao-PDR

World Bank. (2016). The Challenge of engaging communities in Lao PDR: Lessons from the poverty reduction fund project. Vientiane: World Bank. Retrieved from https://ieg.worldbankgroup.org/news/challenge-engaging-communities-lao-pdrlessons-poverty-reduction-fund-project.

World Bank. (n.d). Tool name: Transect walks. Retrieved from http://siteresources.worldbank.org/EXTTOPPSISOU/Resources/1424002$\underline{1185304794278 / 4026035-1185375653056 / 4028835-}$ $1185375678936 / 1$ Transect walk.pdf

Worner, W. (1989). Economic reform and structural change in Laos. Southeast Asian affairs, 187-208.

Yamauchi, S., \& Lee, D. (1999). Tourism development in the Lao People's Democratic Republic. New York: Department of Economic and Social Affairs, United Nations Retrieved from http://www.un.org/esa/esa99dp9.pdf.

Zhang, W. (2011, April 24). Sinohydro, CDB [China Development Bank] ink deal for Nam Ou cascade in Laos. Retrieved from http://damsandalternatives.blogspot.co.nz/2011/04/sinohydro-cdb-ink-deal-fornam-ou.html 


\section{Appendices}

\section{Appendix 1.1 Information sheet for the interviews - Students}

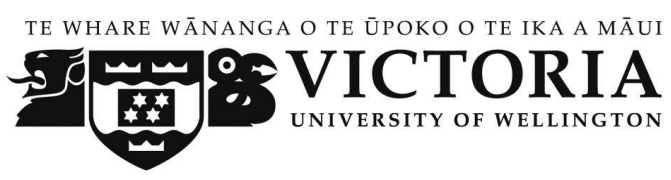

Research title: Understanding the influence of place on the perceptions of vocational education and the occupational aspirations of young rural ethnic groups in northern Laos.

Researcher: Phonexay Soukkaseum

Supervisor: Dr. Marcela Palomino-Schalscha

Sabaidee and thank you for showing your interest in this research project. Please read the information below to gain a better understanding of the project. After reading this paper, please feel free to decide whether or not you would like to take part of the project. If you decide to do so, thank you for your time and contribution. If you decide not to take part, thank you for your consideration of my request and I wish you all the best with your studies or work.

\section{Who am I?}

My name is Phonexay Soukkaseum, a Master's Student in Development Studies at Victoria University of Wellington, New Zealand. As part of the University's requirements for the completion of my studies, I am doing a research project titled: "Understanding the influence of place on the perceptions of vocational education and the occupational aspirations of young rural Ethnic groups in northern Laos."

I have chosen this topic because I am passionate about exploring the educational perceptions and career aspirations of young people from disadvantaged communities. I want to understand how the place where these young people live influences the way they perceive vocational education and aspire for their future careers. I hope the findings of this research will not only serve my personal interest, but will also inform development in theories and practices.

This research project has been reviewed and approved by the Human Ethics Committee of the Victoria University of Wellington in New Zealand. 


\section{What is the aim of the project?}

This research aims to:

- Explore the factors in relation to place that influence the educational perceptions and career aspirations of young people from rural communities and ethnic backgrounds;

- Investigate the extent to which international development agencies have enabled young people to realise their potential through vocational education and career development; and

- Find out the possibilities of creating better spaces for vocational education development among young people from disadvantaged areas.

\section{How will I proceed?}

If you agree to take part, I will invite you for face-to-face interview. The interview will take between 30 to 90 minutes. You will be asked about:

- the characteristics of place: homeland, school, and culture;

- your perceptions towards vocational education and career aspirations;

- your perspectives on what influences their perceptions and aspirations;

- your views on how and why your perceptions and aspirations have changed overtime;

- your capability to make a decision about school choice and career aspirations;

- your learning and socialising experiences while studying at vocational school/university; and

- your perspectives on how can the school effectively help you to achieve your career aspirations.

The time and place for the interview will depend on your availability and choosing where you feel comfortable to talk. With your permission, I will make audio recordings and take notes of our discussions. You can stop the interview at any time without giving a reason.

\section{What will happen after the interviews?}

Your information is confidential. All the records and notes from the discussions will be kept securely. I will transcribe and analyse the information. Only my supervisor and I will read the notes or transcripts of the interview. If data transcribers are required due to my workload, they will be asked to sign a consent form which means that your information will not be disclosed to any other third parties.

Your name will not be mentioned in any reports, unless otherwise agreed. The interview transcripts, summaries, and any recordings will be kept securely and destroyed five years after the research ends.

\section{What will the project produce?}

The final report (thesis) of this project will be published and held in the Victoria University of Wellington library. I may also use the results of my research for 
conference presentations and academic reports. I will take care not to identify you in any presentation or report.

\section{What if you would like to withdraw from taking part of the project?}

You can withdraw from the study up to four weeks after the interview. If you withdraw, the information you provided will be destroyed or returned to you.

\section{If you accept this invitation, what are your rights as a research participant?}

You do not have to accept this invitation if you don't want to. If you do decide to participate, you have the right to:

- choose not to answer any question;

- ask for the recorder to be turned off at any time during the interview;

- withdraw from the study up until four weeks after your interview;

- ask any questions about the study at any time;

- receive a copy of your interview recording (if it is recorded);

- read over and comment on a written summary of your interview;

- agree on another name for me to use rather than your real name;

- be able to read any reports of this research by emailing the researcher to request a copy.

\section{If you have any questions or problems, who can you contact?}

If you have any questions, either now or in the future, please feel free to contact either:

\section{Student:}

Name: Phonexay Soukkaseum

Course: Master of Development Studies

School: School of Geography, Environment, and Earth Sciences

Phone: +85620 55567672 (Laos) +640221404627 (New Zealand)

\section{Supervisor:}

Name: Dr. Marcela PalominoSchalscha

Role: Lecturer

School: School of Geography, Environment, and Earth Sciences

Phone: +64044635899

(New Zealand)

\section{E-mail: marcela.palomino-}

\section{schalscha@vuw.ac.nz}

\section{Human Ethics Committee information}

If you have any concerns about the ethical conduct of the research you may contact the Victoria University HEC Convener: Associate Professor Susan Corbett. Email susan.corbett@vuw.ac.nz or telephone +64 44635480. 


\title{
Appendix 1.2 Information sheet for the interviews - Teachers/school principals/educators
}

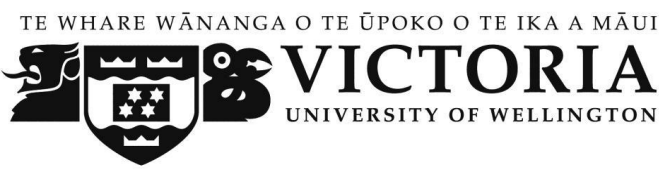

\author{
Research title: Understanding the influence of place on the perceptions of \\ vocational education and the occupational aspirations of young \\ rural ethnic groups in northern Laos. \\ Researcher: Phonexay Soukkaseum \\ Supervisor: $\quad$ Dr. Marcela Palomino-Schalscha
}

Sabaidee and thank you for showing your interest in this research project. Please read the information below to gain a better understanding of the project. After reading this paper, please feel free to decide whether or not you would like to take part of the project. If you decide to do so, thank you for your time and contribution. If you decide not to take part, thank you for your consideration of my request and I wish you all the best with your work.

\section{Who am I?}

My name is Phonexay Soukkaseum, a Master's Student in Development Studies at Victoria University of Wellington, New Zealand. As part of the University's requirements for the completion of my studies, I am doing a research project titled: "Understanding the influence of place on the perceptions of vocational education and the occupational aspirations of young rural Ethnic groups in northern Laos."

I have chosen this topic because I am passionate about exploring the educational perceptions and career aspirations of young people from disadvantaged communities. I want to understand how the place where these young people live influences the way they perceive vocational education and aspire for their future careers. I hope the findings of this research will not only serve my personal interest, but will also inform development in theories and practices.

This research project has been reviewed and approved by the Human Ethics Committee of the Victoria University of Wellington in New Zealand.

\section{What is the aim of the project?}

This research aims to:

- Explore the factors in relation to place that influence the educational perceptions and career aspirations of young people from rural communities and ethnic backgrounds; 
- Investigate the extent to which international development agencies have enabled young people to realise their potential through vocational education and career development; and

- Find out the possibilities of creating better spaces for vocational education development among young people from disadvantaged areas.

\section{How will I proceed?}

If you agree to take part, I will invite you for face-to-face interview. The interview will take between 30 to 90 minutes. You will be asked about:

- your perspectives on students' perceptions of vocational education and career aspirations;

- your perspectives on what influences students' educational perceptions and career aspirations;

- your views on how and why students' perceptions and aspirations have changed overtime;

- your roles in shaping students' perceptions and preparing them to achieve their future careers;

- your physical and emotional support to help students achieve their academic performance and career aspirations;

- your perspectives on students' learning and socialising experiences in the classrooms and outside of the classrooms;

- your perspectives on what influences students' motivation, participation, and engagement in the classroom activities;

- your perspectives on how has Asian Development Bank assistance helped young rural ethnic groups achieve their career aspirations;

- your perspectives on how can the school effectively help students to achieve their career aspirations.

The time and place for the interview will depend on your availability and choosing where you feel comfortable to talk. With your permission, I will make audio recordings and take notes of our discussions. You can stop the interview at any time without giving a reason.

I would like to do school observations (e.g. 'Transit Walk') to observe the school archietchture and design, as well as classroom observations to observe learning and teaching environments. I need to video record the sessions and take notes for the observations. To do this, I will have to ask for your permission.

\section{What will happen after the interviews?}

Your information is confidential. All the records and notes from discussions will be kept securely. I will transcribe and analyse the information. Only my supervisor and I will read the notes or transcripts of the interview. If data transcribers are required due to my workload, they will be asked to sign a consent form which means that your information will not be disclosed to any other third parties.

Your name will not be mentioned in any reports, unless otherwise agreed. The interview transcripts, summaries, and any recordings will be kept securely and destroyed five years after the research ends.

What will the project produce? 
The final report (thesis) of this project will be published and held in the Victoria University of Wellington library. I may also use the results of my research for conference presentations and academic reports. I will take care not to identify you in any presentation or report.

\section{What if you would like to withdraw from taking part of the project?}

You can withdraw from the study up to four weeks after the interview. If you withdraw, the information you provided will be destroyed or returned to you.

\section{If you accept this invitation, what are your rights as a research participant?}

You do not have to accept this invitation if you don't want to. If you do decide to participate, you have the right to:

- choose not to answer any question;

- ask for the recorder to be turned off at any time during the interview;

- withdraw from the study up until four weeks after your interview;

- ask any questions about the study at any time;

- receive a copy of your interview recording (if it is recorded);

- read over and comment on a written summary of your interview;

- agree on another name for me to use rather than your real name;

- be able to read any reports of this research by emailing the researcher to request a copy.

\section{If you have any questions or problems, who can you contact?}

If you have any questions, either now or in the future, please feel free to contact either:

\section{Student:}

Name: Phonexay Soukkaseum

Course: Master of Development Studies

School: School of Geography, Environment, and Earth Sciences

Phone: $\quad+8562055567672$ (Laos) +640221404627

(New Zealand)

E-mail: soukkaphon@myvuw.ac.nz

\section{Supervisor:}

Name: Dr. Marcela PalominoSchalscha

Role: Lecturer

School: School of Geography, Environment, and Earth Sciences

Phone: +64044635899

(New Zealand)

E-mail: marcela.palominoschalscha@vuw.ac.nz

\section{Human Ethics Committee information}

If you have any concerns about the ethical conduct of the research you may contact the Victoria University HEC Convener: Associate Professor Susan Corbett. Email susan.corbett@vuw.ac.nz or telephone +64 44635480. 


\section{Appendix 1.3 Information sheet for the interviews - Parents/elders/village heads}

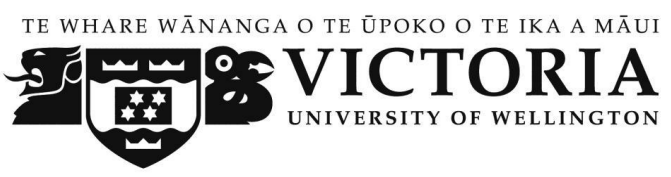

Research title: Understanding the influence of place on the perceptions of vocational education and the occupational aspirations of young rural ethnic groups in northern Laos.

Researcher: Phonexay Soukkaseum

Supervisor: Dr. Marcela Palomino-Schalscha

Sabaidee and thank you for showing your interest in this research project. Please read the information below to gain a better understanding of the project. After reading this paper, please feel free to decide whether or not you would like to take part of the project. If you decide to do so, thank you for your time and contribution. If you decide not to take part, thank you for your consideration of my request and I wish you all the best with your work.

\section{Who am I?}

My name is Phonexay Soukkaseum, a Master's Student in Development Studies at Victoria University of Wellington, New Zealand. As part of the University's requirements for the completion of my studies, I am doing a research project titled: "Understanding the influence of place on the perceptions of vocational education and the occupational aspirations of young rural Ethnic groups in northern Laos."

I have chosen this topic because I am passionate about exploring the educational perceptions and career aspirations of young people from disadvantaged communities. I want to understand how the place where these young people live influences the way they perceive vocational education and aspire for their future careers. I hope the findings of this research will not only serve my personal interest, but will also inform development in theories and practices.

This research project has been reviewed and approved by the Human Ethics Committee of the Victoria University of Wellington in New Zealand.

\section{What is the aim of the project?}

This research aims to:

- Explore the factors in relation to place that influence the educational perceptions and career aspirations of young people from rural communities and ethnic backgrounds; 
- Investigate the extent to which international development agencies have enabled young people to realise their potential through vocational education and career development; and

- Find out the possibilities of creating better spaces for vocational education development among young people from disadvantaged areas.

\section{How will I proceed?}

If you agree to take part, I will invite you for face-to-face interview. The interview will take between 30 to 90 minutes. You will be asked about:

- your perspectives on your child's perceptions of vocational education and career aspirations;

- your perspectives on what influences your child's educational perceptions and career aspirations;

- your views on how and why your child's perceptions and aspirations have changed overtime;

- your roles, as parents, an elder, and a village head, in influencing the educational perceptions and career aspirations of your child;

- the learning and socialising experiences your child have and share with you;

- your physical and emotional support to help your child achieve academic performance and career aspirations;

- your perspectives on how can the school effectively help your child achieve his/her career aspirations.

The time and place for the interview will depend on your availability and choosing where you feel comfortable to talk. With your permission, I will make audio recordings and take notes of our discussions. You can stop the interview at any time without giving a reason.

I would like to do community/household observations (e.g. 'Transit Walk'). I need to video record the sessions and take notes for the observations. To do this, I will have to ask for your permission.

\section{What will happen after the interviews?}

Your information is confidential. All the records and notes from discussions will be kept securely. I will transcribe and analyse the information. Only my supervisor and I will read the notes or transcripts of the interview. If data transcribers are required due to my workload, they will be asked to sign a consent form which means that your information will not be disclosed to any other third parties.

Your name will not be mentioned in any reports, unless otherwise agreed. The interview transcripts, summaries, and any recordings will be kept securely and destroyed five years after the research ends.

\section{What will the project produce?}

The final report (thesis) of this project will be published and held in the Victoria University of Wellington library. I may also use the results of my research for 
conference presentations and academic reports. I will take care not to identify you in any presentation or report.

\section{What if you would like to withdraw from taking part of the project?}

You can withdraw from the study up to four weeks after the interview. If you withdraw, the information you provided will be destroyed or returned to you.

\section{If you accept this invitation, what are your rights as a research participant?}

You do not have to accept this invitation if you don't want to. If you do decide to participate, you have the right to:

- choose not to answer any question;

- ask for the recorder to be turned off at any time during the interview;

- withdraw from the study up until four weeks after your interview;

- ask any questions about the study at any time;

- receive a copy of your interview recording (if it is recorded);

- read over and comment on a written summary of your interview;

- agree on another name for me to use rather than your real name;

- be able to read any reports of this research by emailing the researcher to request a copy.

\section{If you have any questions or problems, who can you contact?}

If you have any questions, either now or in the future, please feel free to contact either:

\section{Student:}

Name: Phonexay Soukkaseum

Course: Master of Development Studies

School: School of Geography, Environment, and Earth Sciences

Phone: +85620 55567672 (Laos) +640221404627 (New Zealand)

\section{E-mail: soukkaphon@myvuw.ac.nz}

\section{Supervisor:}

Name: Dr. Marcela PalominoSchalscha

Role: Lecturer

School: School of Geography, Environment, and Earth Sciences

Phone: +6404 4635899

(New Zealand)

E-mail: marcela.palominoschalscha@vuw.ac.nz

\section{Human Ethics Committee information}

If you have any concerns about the ethical conduct of the research you may contact the Victoria University HEC Convener: Associate Professor Susan Corbett. Email susan.corbett@vuw.ac.nz or telephone +64 44635480. 


\title{
Appendix 1.4 Information sheet for the interviews - Development practitioners/ consultants/ government officials
}

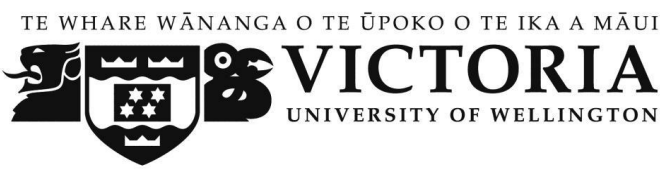

\begin{abstract}
Research title: Understanding the influence of place on the perceptions of vocational education and the occupational aspirations of young rural ethnic groups in northern Laos.

Researcher: Phonexay Soukkaseum

Supervisor: $\quad$ Dr. Marcela Palomino-Schalscha
\end{abstract}

Sabaidee and thank you for showing your interest in this research project. Please read the information below to gain a better understanding of the project. After reading this paper, please feel free to decide whether or not you would like to take part of the project. If you decide to do so, thank you for your time and contribution. If you decide not to take part, thank you for your consideration of my request and I wish you all the best with your work.

\section{Who am I?}

My name is Phonexay Soukkaseum, a Master's Student in Development Studies at Victoria University of Wellington, New Zealand. As part of the University's requirements for the completion of my studies, I am doing a research project titled: "Understanding the influence of place on the perceptions of vocational education and the occupational aspirations of young rural Ethnic groups in northern Laos."

I have chosen this topic because I am passionate about exploring the educational perceptions and career aspirations of young people from disadvantaged communities. I want to understand how the place where these young people live influences the way they perceive vocational education and aspire for their future careers. I hope the findings of this research will not only serve my personal interest, but will also inform development in theories and practices.

This research project has been reviewed and approved by the Human Ethics Committee of the Victoria University of Wellington in New Zealand.

\section{What is the aim of the project?}

This research aims to:

- Explore the factors in relation to place that influence the educational perceptions and career aspirations of young people from rural communities and ethnic backgrounds; 
- Investigate the extent to which international development agencies have enabled young people to realise their potential through vocational education and career development; and

- Find out the possibilities of creating better spaces for vocational education development among young people from disadvantaged areas.

\section{How will I proceed?}

If you agree to take part, I will invite you for face-to-face interview. The interview will take between 30 to 90 minutes. You will be asked about:

- your perspectives towards young rural ethnic groups' perceptions of vocational education and career aspirations;

- your perspectives on what influences these young people's perceptions of vocational education and career aspirations;

- your institutional strategies and interventions that are being used to help young rural ethnic groups achieve their career aspirations;

- the strengths and challenges of implementing the strategies and interventions;

- the lessons learned by your institution in helping young rural ethnic groups achieve their career aspirations;

- your perspectives on how can the school effectively help young rural ethnic groups achieve their career aspirations.

The time and place for the interview will depend on your availability and choosing where you feel comfortable to talk. With your permission, I will make audio recordings and take notes of discussions. You can stop the interview at any time without giving a reason.

I would like to attend the meetings or conferences held by your institution to observe what is being discussed and how participants are engaged. To do this, I will have to ask for your permission.

\section{What will happen after the interviews?}

Your information is confidential. All the records and notes from discussions will be kept securely. I will transcribe and analyse the information. Only my supervisor and I will read the notes or transcripts of the interview. If data transcribers are required due to my workload, they will be asked to sign a consent form which means that your information will not be disclosed to any other third parties.

Your name will not be mentioned in any reports, unless otherwise agreed. The interview transcripts, summaries, and any recordings will be kept securely and destroyed five years after the research ends.

\section{What will the project produce?}

The final report (thesis) of this project will be published and held in the Victoria University of Wellington library. I may also use the results of my research for conference presentations and academic reports. I will take care not to identify you in any presentation or report.

What if you would like to withdraw from taking part of the project? 
You can withdraw from the study up to four weeks after the interview. If you withdraw, the information you provided will be destroyed or returned to you.

If you accept this invitation, what are your rights as a research participant?

You do not have to accept this invitation if you don't want to. If you do decide to participate, you have the right to:

- choose not to answer any question;

- ask for the recorder to be turned off at any time during the interview;

- withdraw from the study up until four weeks after your interview;

- ask any questions about the study at any time;

- receive a copy of your interview recording (if it is recorded);

- read over and comment on a written summary of your interview;

- agree on another name for me to use rather than your real name;

- be able to read any reports of this research by emailing the researcher to request a copy.

\section{If you have any questions or problems, who can you contact?}

If you have any questions, either now or in the future, please feel free to contact either:

\section{Student:}

Name: Phonexay Soukkaseum

Course: Master of Development Studies

School: School of Geography, Environment, and Earth Sciences

Phone: +8562055567672 (Laos) +640221404627

(New Zealand)

E-mail: soukkaphon@myvuw.ac.nz

\section{Supervisor:}

Name: Dr. Marcela Palomino-

Schalscha

Role: Lecturer

School: School of Geography, Environment, and Earth Sciences

Phone: +6404 4635899

(New Zealand)

E-mail: marcela.palomino-

schalscha@vuw.ac.nz

\section{Human Ethics Committee information}

If you have any concerns about the ethical conduct of the research you may contact the Victoria University HEC Convener: Associate Professor Susan Corbett. Email susan.corbett@vuw.ac.nz or telephone +64 44635480. 


\section{Appendix 1.5 Information sheet for focus groups}

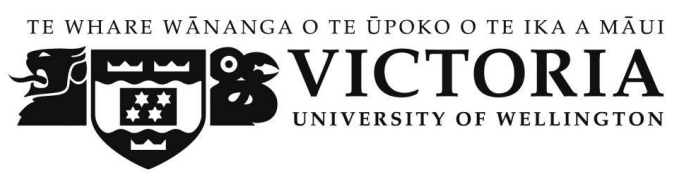

Research title: Understanding the influence of place on the perceptions of vocational education and the occupational aspirations of young rural ethnic groups in northern Laos.

Researcher: Phonexay Soukkaseum

Supervisor: Dr. Marcela Palomino-Schalscha

Sabaidee and thank you for showing your interest in this research project. Please read the information below to gain a better understanding of the project. After reading this paper, please feel free to decide whether or not you would like to take part of the project. If you decide to do so, thank you for your time and contribution. If you decide not to take part, thank you for your consideration of my request and I wish you all the best with your studies or work.

\section{Who am I?}

My name is Phonexay Soukkaseum, a Master's Student in Development Studies at Victoria University of Wellington, New Zealand. As part of the University's requirements for the completion of my studies, I am doing a research project titled: "Understanding the influence of place on the perceptions of vocational education and the occupational aspirations of young rural Ethnic groups in northern Laos."

I have chosen this topic because I am passionate about exploring the educational perceptions and career aspirations of young people from disadvantaged communities. I want to understand how the place where these young people live influences the way they perceive vocational education and aspire for their future careers. I hope the findings of this research will not only serve my personal interest, but will also inform development in theories and practices.

This research project has been reviewed and approved by the Human Ethics Committee of the Victoria University of Wellington in New Zealand.

\section{What is the aim of the project?}

This research aims to:

- Explore the factors in relation to place that influence the educational perceptions and career aspirations of young people from rural communities and ethnic backgrounds; 
- Investigate the extent to which international development agencies have enabled young people to realise their potential through vocational education and career development; and

- Find out the possibilities of creating better spaces for vocational education development among young people from disadvantaged areas.

\section{How will I proceed?}

If you agree to take part, you will be invited to participate in focus group discussions consisting of around 8 people, including yourself. Some of your group members are from the same class as you and some are from other classes within your school.

The discussions will take between 1 to 2 hours and, in your group, you will be asked about:

- the characteristics of place: homeland, school, and culture;

- your perceptions towards vocational education and aspirations for future careers;

- your perspectives on what influences your perceptions and aspirations;

- your views on how and why your perceptions and aspirations have changed overtime;

- your perspectives on how can the school effectively help you to achieve your career aspirations.

You will be asked to answer the questions in the group as a whole as well as in individual. You will be invited to engage in some activities that will help you enjoy the discussions and have fun.

The time for our discussions will depend on your availability and the place to conduct the activity will be decided so it suits all participants involved. With your permission, I will make audio/video recordings and take notes of our discussions. You can leave the discussions at any time, without giving a reason.

Please also note that, if you choose to participate in the focus group, you need to adhere to a confidentiality clause, meaning that you will not share what was said in the group with others.

\section{What will happen after focus group discussions?}

Your information is confidential. All the records and discussions will be kept securely. I will transcribe and analyse the information. Only my supervisor and I will read the notes or transcript of the discussions. If data transcribers are required due to my workload, they will be asked to sign a consent form which means that your information will not be disclosed to any other third parties.

Your name will not be mentioned in any reports, unless otherwise agreed. The interview transcripts, summaries, and any recordings will be kept securely and destroyed five years after the research ends.

\section{What will the project produce?}


The final report (thesis) of this project will be published and held in the Victoria University of Wellington library. I may also use the results of my research for conference presentations and academic reports. I will take care not to identify you in any presentation or report.

\section{What if you would like to withdraw from taking part of the project?}

You can withdraw from the study up to four weeks after the interview. If you withdraw, the information you provided will be destroyed or returned to you.

\section{If you accept this invitation, what are your rights as a research participant?}

You do not have to accept this invitation if you don't want to. If you do decide to participate, you have the right to:

- choose not to answer any question;

- $\quad$ ask for the recorder to be turned off at any time during the discussions;

- withdraw from the study up until four weeks after conducting this activity;

- ask any questions about the study at any time;

- receive a copy of your interview recording (if it is recorded);

- read over and comment on a written summary of our discussions;

- agree on another name for me to use rather than your real name;

- be able to read any reports of this research by emailing the researcher to request a copy.

\section{If you have any questions or problems, who can you contact?}

If you have any questions, either now or in the future, please feel free to contact either:

\section{Student:}

Name: Phonexay Soukkaseum

Course: Master of Development Studies

School: School of Geography, Environment, and Earth Sciences

Phone: +85620 55567672 (Laos) +640221404627 (New Zealand)

\section{Supervisor:}

Name: Dr. Marcela PalominoSchalscha

Role: Lecturer

\author{
School: School of Geography, \\ Environment, and Earth \\ Sciences \\ Phone: +6404 4635899 \\ (New Zealand) \\ E-mail: marcela.palomino-
} schalscha@vuw.ac.nz

\section{Human Ethics Committee information}

If you have any concerns about the ethical conduct of the research you may contact the Victoria University HEC Convener: Associate Professor Susan Corbett. Email susan.corbett@vuw.ac.nz or telephone +64 44635480. 


\section{Appendix 2.1 Participant consent form - Interviews}

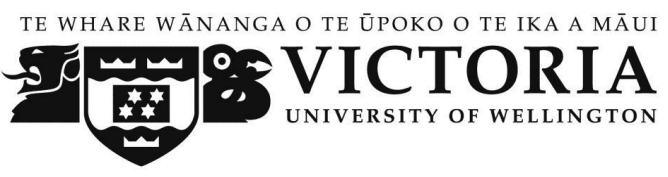

Research title: Understanding the influence of place on the perceptions of vocational education and the occupational aspirations of young rural ethnic groups in northern Laos.

Researcher: Phonexay Soukkaseum

Supervisor: Dr. Marcela Palomino-Schalscha

I have read or had explained to me the 'Participant Consent Form.' The researcher has also explained to me about the process of the interview. I understand that I can stop the interview at any time without any reason.

By signing below, I acknowledge that;

- My identity will be kept confidential so my real name will not be mentioned in any reports, unless otherwise agreed;

- I may withdraw from this study up to four weeks after the interview, and any information that I have provided will be returned to me or destroyed;

- The information I have provided will be destroyed five years after the research ends;

- I permit my input and any information I provide to be interpreted, analysed, and published in student reports and in a thesis, as well as to be presented at conferences and to be available in other forms of publication such as journal articles and magazine or newspaper articles.

Please check where is applied:

$\square$ I permit the researcher to make audio/video recordings.

$\square$ I permit the researcher to use my quotes in the research.

$\square \quad$ I request a summary of my interview.

$\square$ I request to receive a summary of the report via my address below.

$\mathrm{I}$, , agree and consent to the above statements.

Signature:

Date:

Position:

Institution:

Mobile:

E-mail: 


\section{Appendix 2.2 Participant consent form - Focus groups}

TE WHARE WĀNANGA O TE ŪPOKO O TE IKA A MĀUI

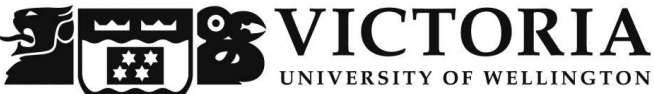

Research title: Understanding the influence of place on the perceptions of vocational education and the occupational aspirations of young rural ethnic groups in northern Laos.

Researcher: Phonexay Soukkaseum

Supervisor: Dr. Marcela Palomino-Schalscha

I have read or had explained to me the 'Participant Consent Form.' The researcher has also explained to me about the process of the conducting focus groups. I understand that I can stop getting involved in the discussions at any stage without having to explain why.

By signing below, I acknowledge that;

- My identity will be kept confidential so my real name will not be mentioned in any reports, unless otherwise agreed;

- All the information shared during the focus group should remain confidential. I therefore agree not to share or comment with anyone else what participants said in the discussion.

- I may withdraw from this study up to four weeks after conducting focus group discussions, and any information that I have provided will be returned to me or destroyed;

- The information I have provided will be destroyed five years after the research ends;

- I permit my input and any information I provide to be interpreted, analysed, and published in student reports and in a thesis, as well as to be presented at conferences and to be available in other forms of publication such as journal articles and magazine or newspaper articles.

Please check where is applied:

I agree the focus groups being audio/ video recorded.

$\square$ I agree to some of my statements being quoted in the research.

$\square$ I acknowledge the confidentiality of our focus group discussions and that what we discuss will be kept among our group members.

$\square$ I request to receive a summary of the report via my address below.

$\mathrm{I}$, agree and consent to the above statements.

Signature:

Date: 
Position:

Mobile:
Institution:

E-mail: 
Research title: Understanding the influence of place on the perceptions of vocational education and the occupational aspirations of young rural ethnic groups in northern Laos.

Researcher: Phonexay Soukkaseum

Supervisor: Dr. Marcela Palomino-Schalscha

\section{1) Interview questions for students}

\begin{tabular}{|c|c|}
\hline Categories/themes & Questions \\
\hline $\begin{array}{l}\text { (i) Characteristics of } \\
\text { place: homeland and } \\
\text { culture }\end{array}$ & $\begin{array}{l}\text { 1. Where did you grow up? } \\
\text { 2. What is the place like where you grew up? } \\
\text { 3. What do people in that place do to make a living? } \\
\text { 4. How do you feel about that place? } \\
\text { 5. What does it mean for you? }\end{array}$ \\
\hline $\begin{array}{l}\text { (ii) Perceptions of } \\
\text { vocational education } \\
\text { and influential } \\
\text { factors }\end{array}$ & $\begin{array}{l}\text { 6. What is your view of training and vocational } \\
\text { education? } \\
\text { 7. Who and what makes you think in such a way? } \\
\text { 8. Has your view changed overtime? If so, how? } \\
\text { 9. What are the implications of changing your view? }\end{array}$ \\
\hline $\begin{array}{l}\text { (iii) Educational } \\
\text { choice making, } \\
\text { influential factors }\end{array}$ & $\begin{array}{l}\text { 10. How did you make your choice of education? } \\
\text { 11. Who and what influenced your educational choice- } \\
\text { making? } \\
\text { 12. Does the place where you live affect the choice you } \\
\text { make for your education? If so, how? }\end{array}$ \\
\hline $\begin{array}{l}\text { (iv) Career } \\
\text { aspirations and } \\
\text { influential factors }\end{array}$ & $\begin{array}{l}\text { 13. What do you want to do in the future to make a } \\
\text { living? Why did you decide to do this? } \\
\text { 14. How did you set your career aspirations? What } \\
\text { influences or inspires you to set your aspirations? } \\
\text { 15. Have your career aspirations changed over time? If } \\
\text { so, how? } \\
\text { 16. What are the implications of changing your } \\
\text { aspirations? }\end{array}$ \\
\hline $\begin{array}{l}\text { (v) Learning and } \\
\text { socialising } \\
\text { experiences }\end{array}$ & $\begin{array}{l}\text { 17. Tell me about your learning experience while } \\
\text { studying here at the training and vocational } \\
\text { institution/university. } \\
\text { 18. What skills and knowledge have you gained as the } \\
\text { most important things to help you achieve your } \\
\text { career aspirations? }\end{array}$ \\
\hline
\end{tabular}




\begin{tabular}{|l|l|}
\hline & $\begin{array}{l}\text { 19. Tell me about your socialising or social networking } \\
\text { experience while studying here. } \\
\text { 20. How has this social networking helped improve } \\
\text { your academic performance? And how will it help } \\
\text { you achieve your career in the future? }\end{array}$ \\
\hline $\begin{array}{l}\text { (vi) The influence of } \\
\text { school on the } \\
\text { perceptions and } \\
\text { aspirations }\end{array}$ & $\begin{array}{l}\text { 21. What does school mean for you? } \\
\text { 22. How has attending this school changed your view } \\
\text { about training and vocational education? }\end{array}$ \\
\hline $\begin{array}{l}\text { 23. How does the school help you to achieve your } \\
\text { career aspirations? }\end{array}$ \\
$\begin{array}{l}\text { future vocational } \\
\text { education }\end{array}$ & $\begin{array}{l}\text { 24. How can the school help you achieve your career } \\
\text { aspirations in the future? }\end{array}$ \\
\hline
\end{tabular}

\section{2) Interview questions for teachers/school principals/educators}

\begin{tabular}{|c|c|}
\hline Categories/themes & Questions \\
\hline $\begin{array}{l}\text { (i) The influence of } \\
\text { place on students' } \\
\text { educational } \\
\text { perceptions and career } \\
\text { aspirations }\end{array}$ & $\begin{array}{l}\text { 1. What do you know about young rural ethnic } \\
\text { students' perceptions of training and vocational } \\
\text { education and career aspirations? } \\
\text { 2. What do you think are the influential factors on } \\
\text { their educational perceptions and career } \\
\text { aspirations? } \\
\text { 3. Do you think the place where they live and the } \\
\text { culture they belong influence their educational } \\
\text { perceptions and career aspirations? If so, how? } \\
\text { 4. What do you consider as factors that influence } \\
\text { academic choice-making and career aspiration } \\
\text { setting of young rural ethnic students? } \\
\text { 5. Do you think their educational perceptions and } \\
\text { career aspirations have changed overtime? If so, } \\
\text { how? } \\
\text { 6. What could potentially be the factors influencing } \\
\text { these changes? }\end{array}$ \\
\hline $\begin{array}{l}\text { (ii) Role of school in } \\
\text { influencing and } \\
\text { preparing students for } \\
\text { the future }\end{array}$ & $\begin{array}{l}\text { 7. How do you prepare young rural ethnic students for } \\
\text { their future careers? } \\
\text { 8. What does your training and vocational institution } \\
\text { provide to encourage learning, enhance capability, } \\
\text { and promote creativity among young rural ethnic } \\
\text { groups? }\end{array}$ \\
\hline $\begin{array}{l}\text { (iii) Students' } \\
\text { learning and } \\
\text { socialising } \\
\text { experiences, } \\
\text { motivations, } \\
\text { participations, } \\
\text { engagements in the } \\
\text { classrooms }\end{array}$ & $\begin{array}{l}\text { 9. What is the learning and teaching environment like } \\
\text { in your training and vocational } \\
\text { institution/classrooms? } \\
\text { 10. What do young rural ethnic students like the most } \\
\text { about studying at this training and vocational } \\
\text { institution? } \\
\text { 11. What factors influence these students' motivation, } \\
\text { participation, and engagement in the classrooms? }\end{array}$ \\
\hline
\end{tabular}




\begin{tabular}{|l|l|}
\hline & $\begin{array}{l}\text { 12. What difficulties do you think young rural ethnic } \\
\text { students experience in the classrooms? } \\
\text { 13. What difficulties do young rural ethnic students } \\
\text { experience outside the classrooms? } \\
\text { 14. As a teacher/principal, what is your role in helping } \\
\text { them overcome these difficulties? } \\
\text { 15. What physical and emotional support do you make } \\
\text { to help these students to achieve their academic } \\
\text { performance and career goals? }\end{array}$ \\
\hline $\begin{array}{l}\text { (iv) The impact of } \\
\text { young people's } \\
\text { perceptions and } \\
\text { aspirations }\end{array}$ & $\begin{array}{l}\text { 16. How has Asian Development Bank assistance } \\
\text { helped young rural ethnic groups achieve their } \\
\text { career aspirations? }\end{array}$ \\
\hline $\begin{array}{l}\text { (v) Aspirations for } \\
\text { future vocational } \\
\text { education }\end{array}$ & $\begin{array}{l}\text { 17. Can you think of any ways of how can the school } \\
\text { effectively help young rural ethnic students achieve } \\
\text { their career aspirations in the future? }\end{array}$ \\
\hline
\end{tabular}

\section{3) Interview questions for parents/elders/village heads}

\begin{tabular}{|c|c|}
\hline Categories/themes & Questions \\
\hline $\begin{array}{l}\text { (i) The influence of } \\
\text { place on students' } \\
\text { educational } \\
\text { perceptions and career } \\
\text { aspirations }\end{array}$ & $\begin{array}{l}\text { 1. What do you know about your child's perceptions } \\
\text { of vocational education and career aspirations? } \\
\text { 2. What could be the influential factors on your } \\
\text { child's educational perceptions and career } \\
\text { aspirations? } \\
\text { 3. Do you think the place where they live and the } \\
\text { culture they belong influence their educational } \\
\text { perceptions and career aspirations? If so, how? } \\
\text { 4. What do you consider as factors that influence } \\
\text { academic choice-making and career aspiration } \\
\text { setting of your child? } \\
\text { 5. Do you think your child's educational perceptions } \\
\text { and career aspirations have changed overtime? If } \\
\text { so, how? } \\
\text { 6. What could potentially be the factors influencing } \\
\text { these changes? }\end{array}$ \\
\hline $\begin{array}{l}\text { (ii) The role of family } \\
\text { in influencing } \\
\text { children' perceptions } \\
\text { and aspirations }\end{array}$ & $\begin{array}{l}\text { 7. Do you think your culture and the place where your } \\
\text { child grew up determines his/her decision-making } \\
\text { on the kind of studies, the school, and future career? } \\
\text { If so, how? } \\
\text { 8. How do you involve in the decision-making of your } \\
\text { child in terms of the kinds of studies, the school, and } \\
\text { the future career choices? } \\
\text { 9. How do you encourage and support your child to } \\
\text { attend training and vocational institution and inspire }\end{array}$ \\
\hline
\end{tabular}




\begin{tabular}{|l|l|}
\hline & \multicolumn{1}{|c|}{$\begin{array}{l}\text { him/her on what he/she should do for a career in the } \\
\text { future? } \\
\text { 10. Tell me about the learning experiences your children } \\
\text { share with you and how do you help your child cope } \\
\text { with learning difficulties? } \\
\text { 11. Tell me about the socializing experience your } \\
\text { children share with you and how do you help your } \\
\text { child cope with socializing issues? } \\
\text { 12. What kind of support do you provide to your child } \\
\text { for him/her to be successful in his/her learning and } \\
\text { future careers? }\end{array}$} \\
\hline $\begin{array}{l}\text { (iii) The role of } \\
\text { school in helping } \\
\text { young people to } \\
\text { achieve their career } \\
\text { goals }\end{array}$ & $\begin{array}{l}\text { 13. What does school mean for you and your child? } \\
\text { 14. What do you think your child will do after his/her } \\
\text { graduation? Where? Why? } \\
\text { 15. What work do you want your child to do in the } \\
\text { future? Where? Why? } \\
\text { 16. How does the school help your child to achieve } \\
\text { his/her career goals? } \\
\text { 17. Can you think of any ways of how can the school } \\
\text { effectively help your child achieve his/her career } \\
\text { aspirations in the future? } \\
\text { 18. Is there anything else you would like to add or } \\
\text { comment on? }\end{array}$ \\
\hline
\end{tabular}

\section{4) Interview questions for development practitioners/ consultants/ government officials}

\begin{tabular}{|c|c|}
\hline Categories/themes & Questions \\
\hline $\begin{array}{l}\text { (i) The influence of } \\
\text { place on young rural } \\
\text { ethnic groups' } \\
\text { perceptions and } \\
\text { aspirations }\end{array}$ & $\begin{array}{l}\text { 1. What is your view towards the perceptions of } \\
\text { training and vocational education and career } \\
\text { aspirations of young rural ethnic groups in the } \\
\text { northern region of Laos? } \\
\text { 2. What do you think influences their perceptions and } \\
\text { aspirations? } \\
\text { 3. Do you think their homelands, school, and culture } \\
\text { play a significant role in influencing their } \\
\text { perceptions and aspirations? If so, how? }\end{array}$ \\
\hline $\begin{array}{l}\text { (ii) The institutional } \\
\text { strategies and } \\
\text { interventions }\end{array}$ & $\begin{array}{l}\text { 4. What strategies and interventions are your } \\
\text { institution used to shape the perceptions and } \\
\text { aspirations of these young people? } \\
\text { 5. What are the strengths and challenges in using } \\
\text { these strategies and intervention? } \\
\text { 6. How have these strategies and interventions helped } \\
\text { young rural ethnic groups to achieve their career } \\
\text { aspirations? }\end{array}$ \\
\hline $\begin{array}{l}\text { (iii) The lessons } \\
\text { learned and options } \\
\text { for vocational } \\
\text { education }\end{array}$ & $\begin{array}{l}\text { 7. What are your lessons learned in helping young } \\
\text { rural ethnic groups achieve their career aspirations? }\end{array}$ \\
\hline
\end{tabular}


8. What are the opportunities or options to effectively help young rural ethnic groups achieve their aspirations?

9. Is there anything else you would like to add or comment on? 


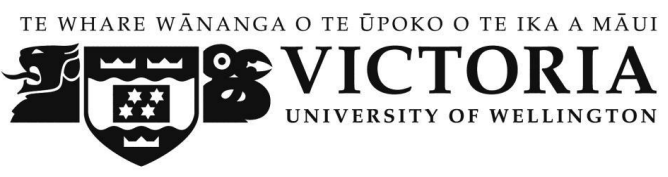

Research title: Understanding the influence of place on the perceptions of vocational education and the occupational aspirations of young rural ethnic groups in northern Laos.

Researcher: Phonexay Soukkaseum

Supervisor: Dr. Marcela Palomino-Schalscha

\section{Participants}

1. Students, the vocational and training school

\section{Guide}

Selecting participants:

- Students will be purposely selected by the researcher with the support of teachers. The researcher will ensure that selected students have a wide range of age, gender, geographical areas, school class, and socioeconomic status.

- Time and place to be conducted the focus groups will be determined by students. However, a negotiation may sometimes take place so that the interviews can be accomplished as planned.

- Students' profile and interview schedule will be prepared.

\section{Briefing to participants:}

- Students will be invited to participate the focus group discussions in accordance with the schedule.

- The researcher will introduce himself and explain the purpose of the study to the participants.

- The participants will be explained about the 'participant information sheet' or will be given the sheet to read by themselves.

- If the students agree to take part, they will be asked to sign the 'consent form' or have 'oral consent.'

- The researcher shall make sure that the participants feel comfortable and are ready for the activity. This can be done by familiarising himself to the research participants.

- The researcher will explain the activities to be conducted as described in table below. 


\section{Questions and activities}

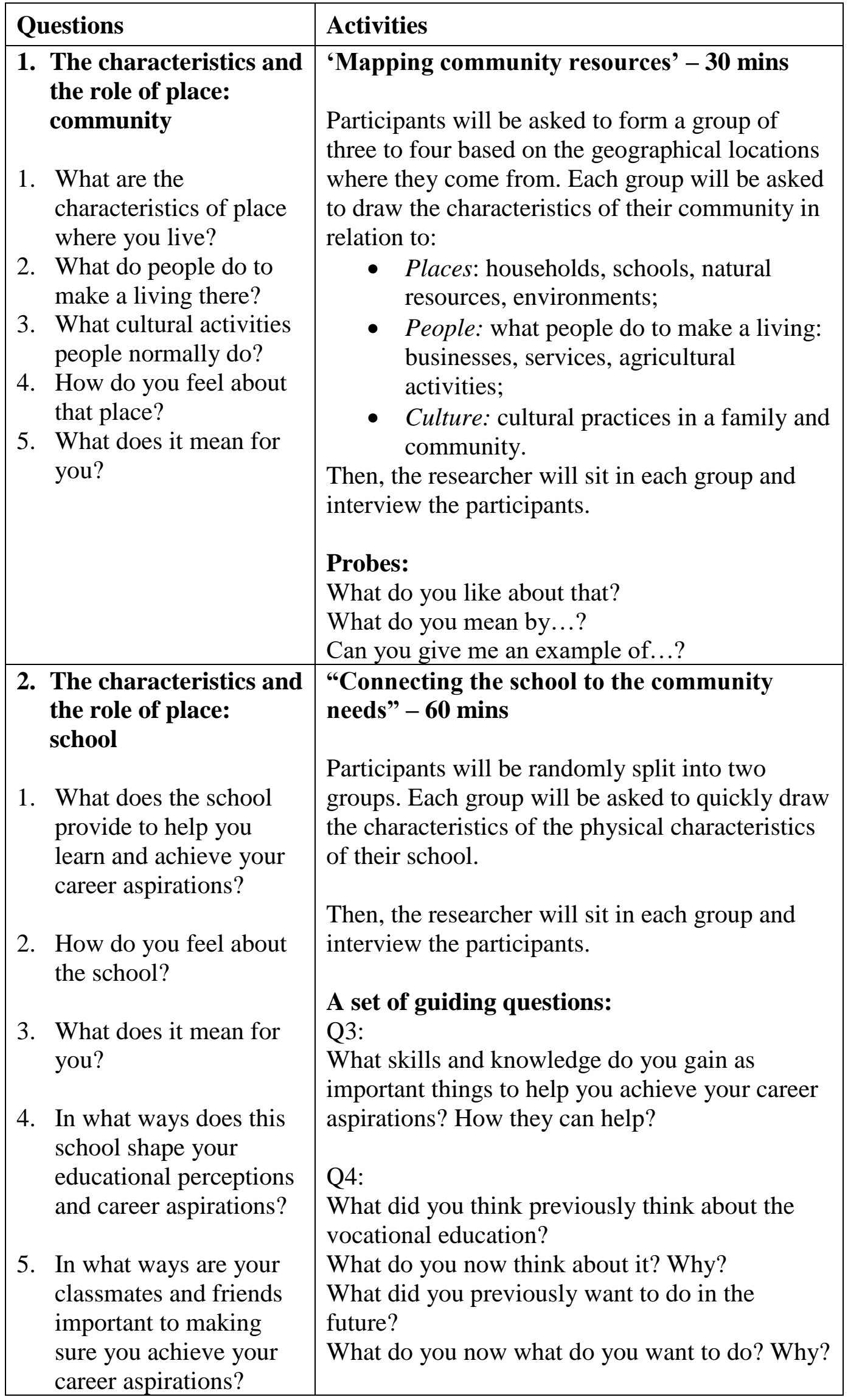




\begin{tabular}{|l|l|}
\hline $\begin{array}{l}\text { 3. Connecting school to } \\
\text { future career } \\
\text { aspirations of young } \\
\text { people }\end{array}$ & $\begin{array}{l}\text { "Conducting dream exercise - the MetaCards } \\
\text { approach"-30 mins }\end{array}$ \\
$\begin{array}{l}\text { 1. What do you see } \\
\text { yourself doing in five } \\
\text { years? Why? }\end{array}$ & $\begin{array}{l}\text { The participants will be asked to return to } \\
\text { their original group from the beginning }\end{array}$ \\
$\begin{array}{l}\text { The participants will be asked to think of } \\
\text { what they have now (resources, skills, and } \\
\text { knowledge) and what they want to do in the } \\
\text { next five years. Then they will be asked to } \\
\text { brainstorm what is needed to help them } \\
\text { achieve their aspirations (see Figure 3). }\end{array}$ \\
$\begin{array}{l}\text { 3. What can the training } \\
\text { and vocational } \\
\text { institution help you to } \\
\text { get there? }\end{array}$ & $\begin{array}{l}\text { The rearcher then interviews each } \\
\text { participant regarding his/her aspirations as to } \\
\text { why he/she wants to do that and how can } \\
\text { he/she gets there. }\end{array}$ \\
\hline
\end{tabular}

Sample: Dream exercise - The MetaCards Approach

What is needed to help young people achieve what they want to do in the next five years?

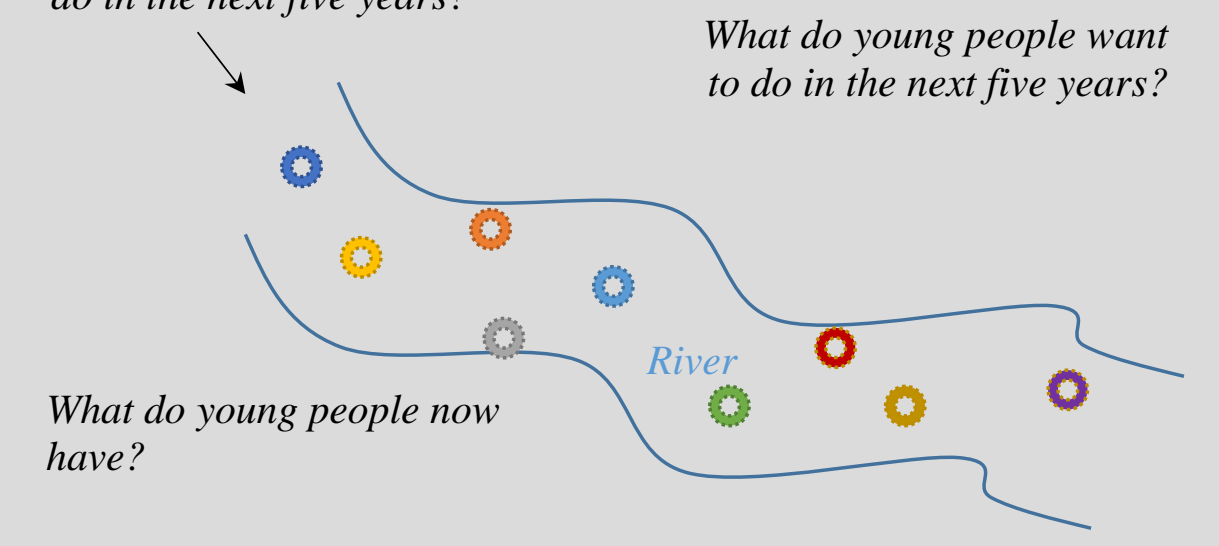

Note: Colour dots $=$ resources, skills and knowledge, etc. 
Research title: Understanding the influence of place on the perceptions of vocational education and the occupational aspirations of young rural ethnic groups in northern Laos.

Researcher: Phonexay Soukkaseum

Supervisor: Dr. Marcela Palomino-Schalscha

\section{Observation guide}

Community observations will take the 'transit walk' technique which means that the researcher will map out the community and take a walk through/ around the community from one point to another. The research may invite the elderly people/parents/head of villagers to accompany when doing this activity.

- Make appointment with the head of villagers/parents/elderly people when to take a community walk.

- During day-and night-time, walk around the community to observe people and things in the market, on the street, farm, water pond, etc.

- Take picture and notes when appropriate. Ask people to sign the consent form or oral consent if they agree to have their photos taken.

\section{What to observe?}

\begin{tabular}{|c|c|}
\hline Categories/themes & Questions \\
\hline Community settlement & $\begin{array}{l}\text { 1. How is the community settled? (community } \\
\text { design, a house type, and community } \\
\text { facilities) }\end{array}$ \\
\hline Community livelihoods & $\begin{array}{l}\text { 2. What do people do to make a living? } \\
\text { 3. Where and how do people get food and water? }\end{array}$ \\
\hline $\begin{array}{l}\text { Community resources/ } \\
\text { asset }\end{array}$ & $\begin{array}{l}\text { 4. What do young people like to do in the } \\
\text { community with the existing resources/asset to } \\
\text { make a living? } \\
\text { 5. What seems to be the barriers and } \\
\text { opportunities of young people to do schooling } \\
\text { and make a living? }\end{array}$ \\
\hline
\end{tabular}




\section{Appendix 4 Human ethics approval}

TE WHARE WINANGA O TE ŨPOKO O TE IKA A MÄUI

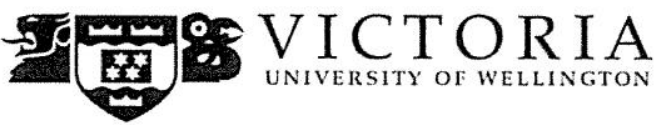

MEMORANDUM

Phone $\quad 0-4-4635205$

Email stephen.marshall@vuw.ac.nz

\begin{tabular}{l|l}
\hline TO & Phonexay Soukkaseum \\
\hline COPY TO & \\
\hline FROM & Dr Stephen Marshall, Acting Convener, Human Ethics Committee \\
\hline & \\
\hline DATE & 26 May 2016 \\
\hline PAGES & 1 \\
\hline
\end{tabular}

\begin{tabular}{l|l}
\hline SUBJECT & $\begin{array}{l}\text { Ethics Approval: 22526 } \\
\text { Understanding the influence of place on the perceptions of } \\
\text { vocational education and the occupational aspirations of young } \\
\text { rural ethnic groups in northern Laos }\end{array}$ \\
\hline
\end{tabular}

Thank you for your application for ethical approval, which has now been considered by the Standing Committee of the Human Ethics Committee.

Your application has been approved from the above date and this approval continues until 15 February 2017. If your data collection is not completed by this date you should apply to the Human Ethics Committee for an extension to this approval.

Best wishes with the research.

Stephen Marshall,

Acting Convener, Victoria University Human Ethics Committee 


\section{Appendix 5 Support letter from supervisor for data collection}

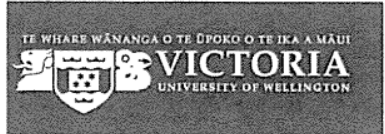

SCHOOL OF GEOGRAPHY, ENVIRONMENT AND EARTH SCIENCES

TE KURA TATĀI ARO WHENUA

VICTORIA UNIVERSITY OF WELLINGTON, PO Box 600, Wellington 6140, New Zealand

Phone +64-4-4635334 Fax +64-4-4635261 Email geo-enquiries@vuw.ac.nz Web www.victoria.ac.nz/sgees

\section{To Whom It May Concern}

I am writing this letter as the supervisor of Mr Phonexay Soukkaseum to support him in collecting data for his Master thesis.

Phonexay is was awarded a scholarship by New Zealand Aid program to complete a Master degree in Development Studies in School of Geography, Environment and Earth Sciences, Victoria University of Wellington, New Zealand. In order to complete this degree, he needs to conduct research and write a thesis based on fieldwork in Laos during 2016.

During his data collection, please assist him in providing relevant information to complete his thesis. If you have any questions or require any further information, please contact me on +64 44635899 or marcela.palomino-schalscha@vuw.ac.nz

Yours sincerely

Date: 19 May 2016

Dr Marcela Palomino-Schalscha

Lecturer in Human Geography and Development Studies

Victoria University of Wellington 


\section{Appendix 6.1 Request letter to Ministry of Education and Sports for data collection}

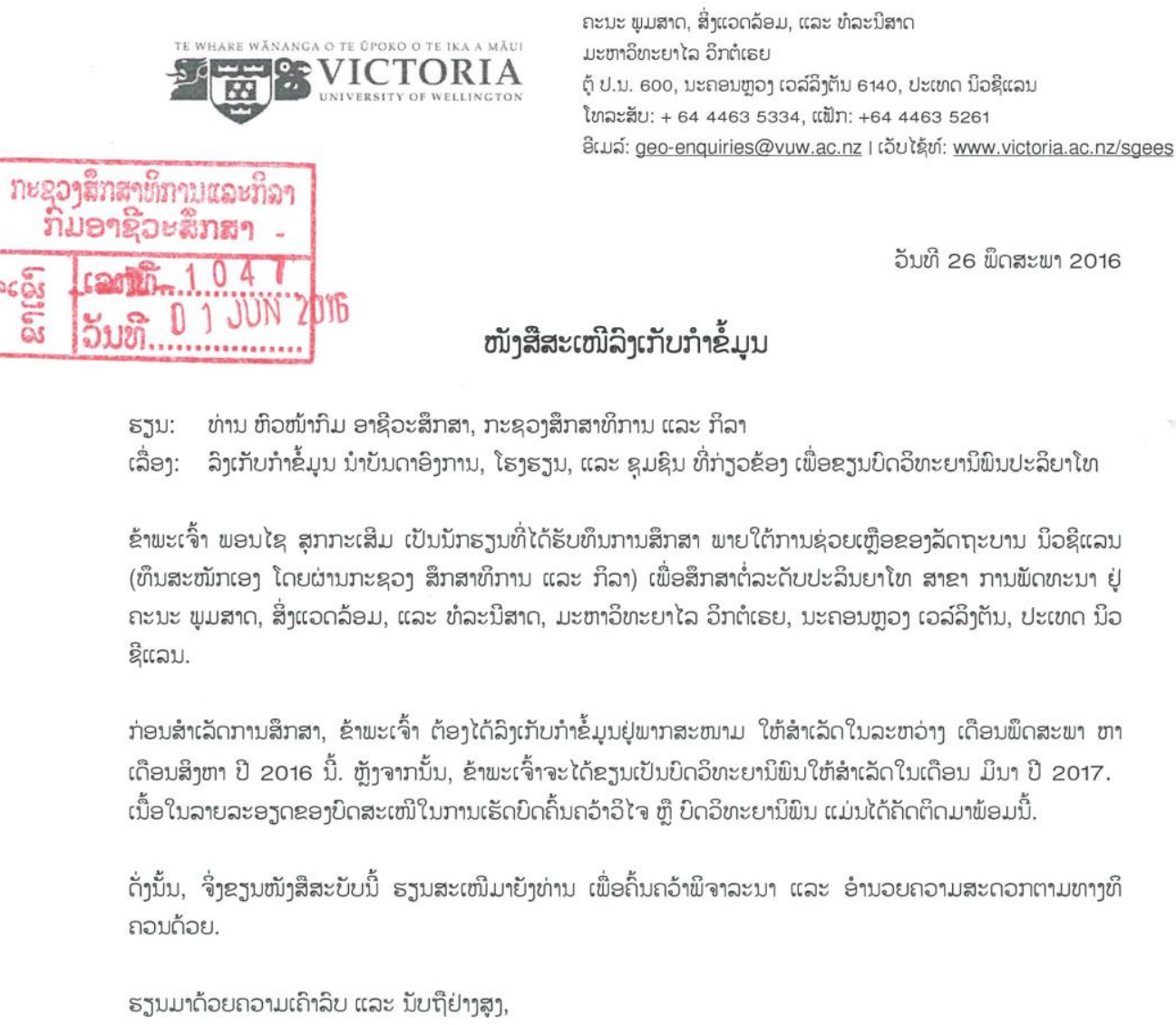

ขิ่ มะถงบขูอง อรงจับ, อับขิ 26 พึกสะขง 2016

เยระสาบถักติถ:

\section{พอบ่า ซุรทยเส็ม}

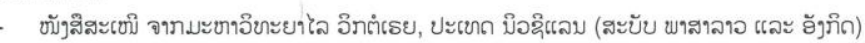

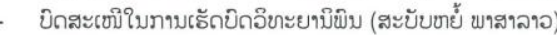

- บิถสะเขึใบภามเรักบิกอ๊ยะยามิพิม (สะบับสิมบุม พาสาชังภึก)

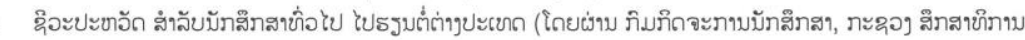
และ ก็ลฯ) 


\section{Appendix 6.2 Approval letter from Ministry of Education and Sports for data collection}

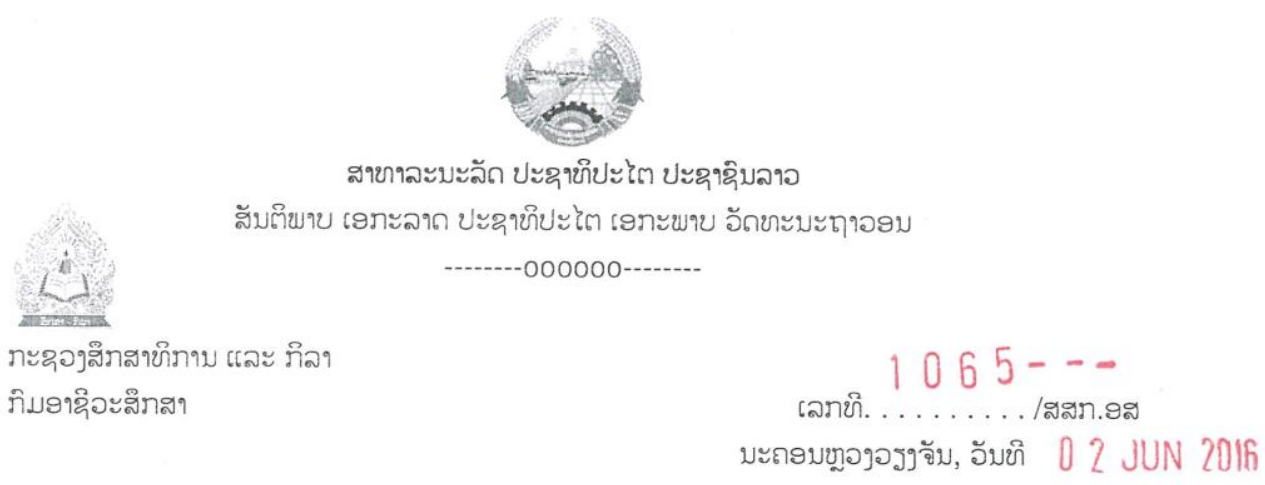

เทิร: ข่าม

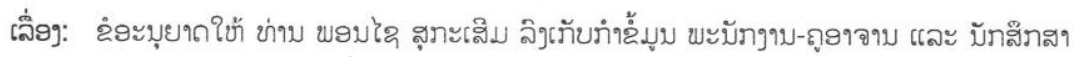

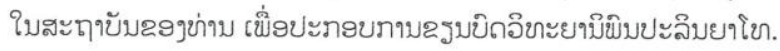

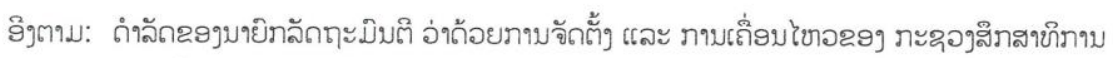

และ ภลา สะบับเลภย์ 282/บย, ลิรอับย์ 07 กับยง 2011;

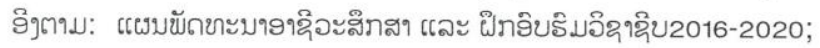

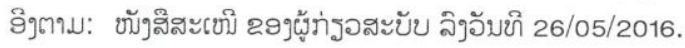

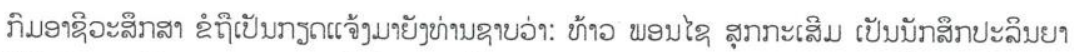

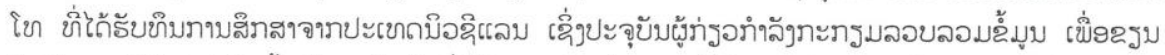

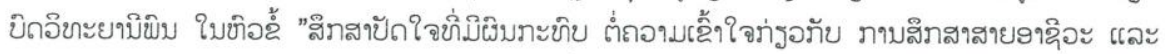

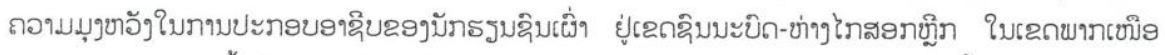

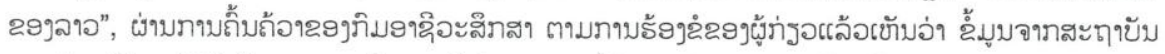

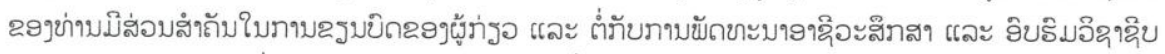

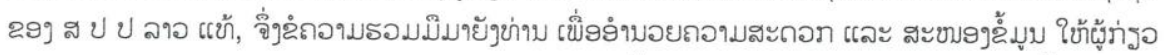

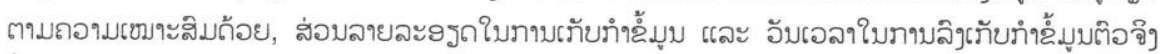
มั้ม ณบ่บของร่รอ จะปะสาบยาติ่ม.

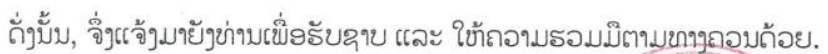

ติกต่บิอิับ:

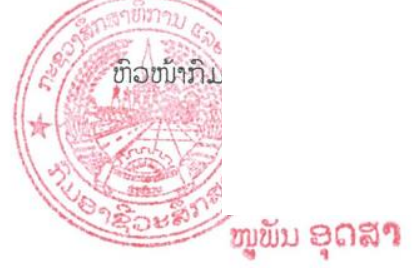

ข่าม ขยบไว สุภาะเส็ม 02055567672

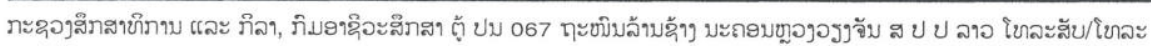
สาบ: 021216473 , 


\section{Appendix 7.1 Request letter to Luang Prabang Provincial Governor Office for data collection}

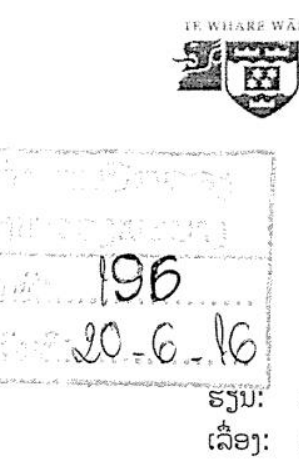

ถะมะ แุมสาก, ส่วแอกล้งม, และ ข่ละบีสาก มะขาอิยะยาไล วิภต่เธย ตุ้ ป.ม. 600 , มะถรบขูอย เอล์ลิวตัม 6140 , ปะเยกก มือฉิแเลบ ใขละสับ: + 6444635334 , แขัภ: +64 44635261

ดิเมล์: geo-enquiries@vuw.ac.nz | เอับได้ข́: www.victoria.ac.nz/sgees

อับขึ 20 ป็ฤุา 2016

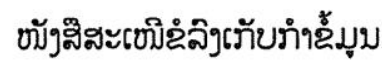

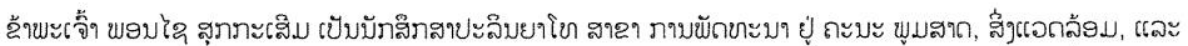

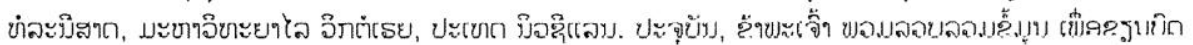

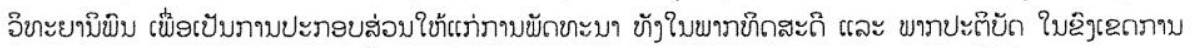

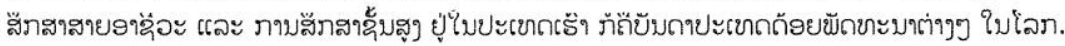

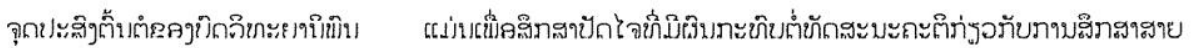

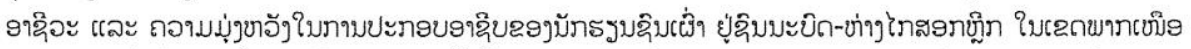

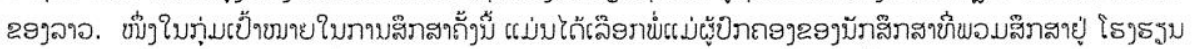

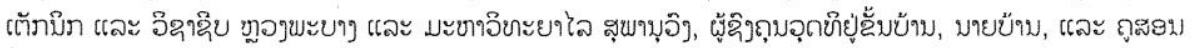

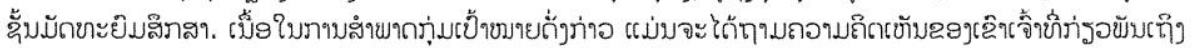

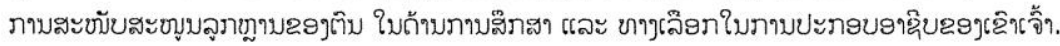

เปิองเขีทยมาย เศละ ไลยะเอลาลิงเรักอรภ:
โขบได
$29 / 6-6 / 7 / 2016$
เป็ดรgอย
$7 / 7-14 / 7 / 2016$

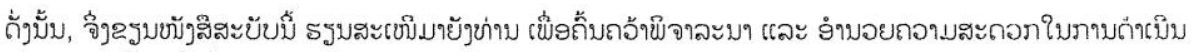

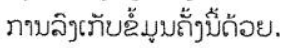

ธรมมาถ้อยถอามเถิาลิบ และ บับฤีย่างสูง,

ผ้สะะขึิ

\section{ขอบไะ ธุกาะเป็น}

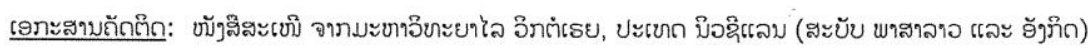

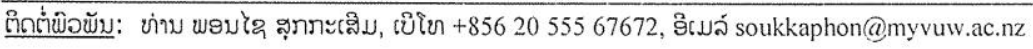




\section{Appendix 7.2 Approval letter from Luang Prabang Provincial Governor Office for data collection}

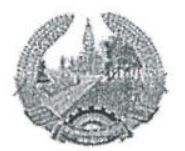

สายาจะบะลัก ปะฉๆขึปะไต ปะฉาฉิบลาอ

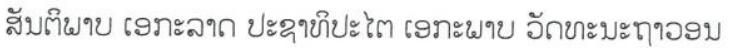

ข้องอ่าราบปิภถงตัเฉอง

แฉองขูองษะบๆง

\author{
เลภขิ_ 505 /ขทป.ขูบ \\ ล์ตับข๊๋ 24 มีทบฯ (06) 2016
}

\section{แจ้าราบบ}

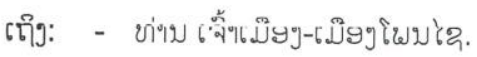

- ข่าม เจิ้าเป็อง-เนิองตรอย.

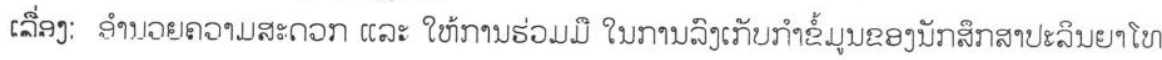

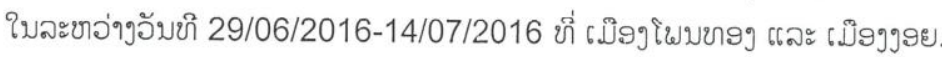

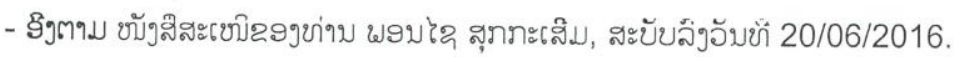

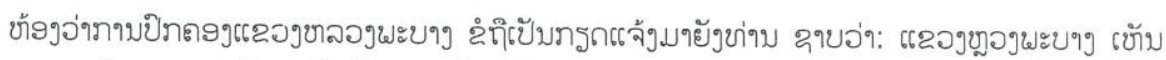

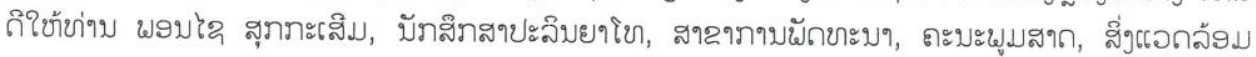

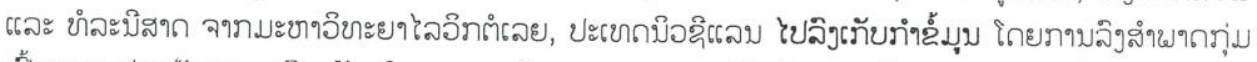

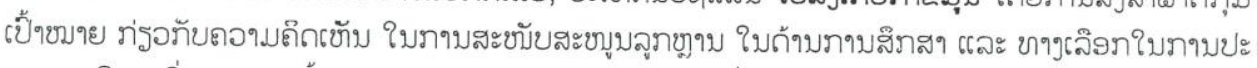

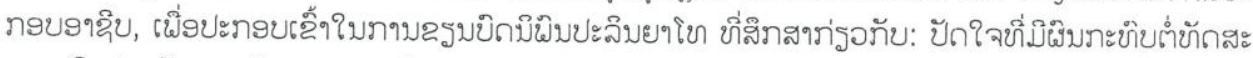

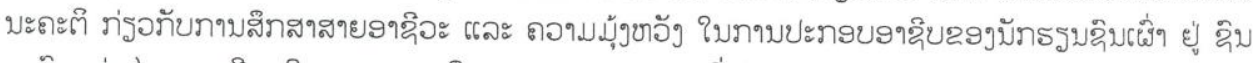

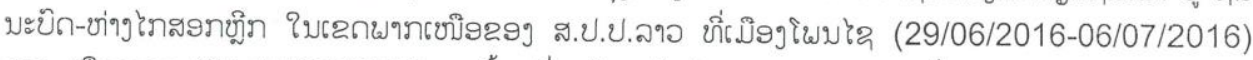

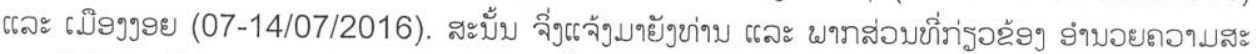

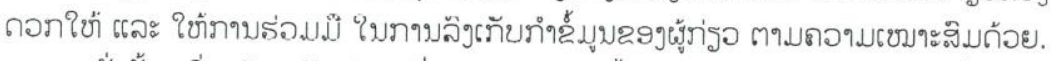

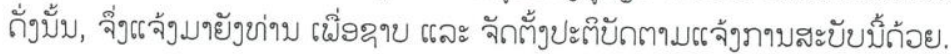

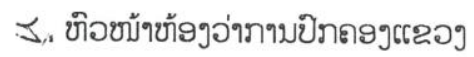

บู่อบม่าติ่:

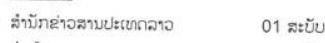

ม่านก่า

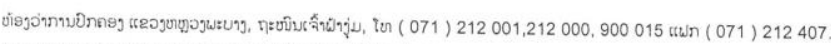

BUREAU deL' ADMINISTRATION PROVINCIALE do LUANGPRABANG. SNP 21.06.2016
} 